\title{
The Dynamics of Poverty and its Determinants: The Case of the Northeast of Brazil and its States
}

\author{
Norbert M. Fiess Dorte Verner
}

\author{
The World Bank
}

nfiess@worldbank.org

dverner@worldbank.org

\begin{abstract}
World Bank Policy Research Working Paper 3259, April 2004
The Policy Research Working Paper Series disseminates the findings of work in progress to encourage the exchange of ideas about development issues. An objective of the series is to get the findings out quickly, even if the presentations are less than fully polished. The papers carry the names of the authors and should be cited accordingly. The findings, interpretations, and conclusions expressed in this paper are entirely those of the authors. They do not necessarily represent the view of the World Bank, its Executive Directors, or the countries they represent. Policy Research Working Papers are available online at http://econ.worldbank.org.
\end{abstract}

The authors would like to thank Joachim von Amsberg and Norbert Schady for helpful comments. 


\section{Introduction}

In 1998, 174 millions of the population in Latin America lived in poverty ${ }^{1}$. About 20.4 million people or 15 percent of Latin America's poor were concentrated in the Northeast of Brazil. The Northeast Region of Brazil includes nine of the country's 23 states: Alagoas, Bahia, Ceará, Maranhão, Pernambuco, Paraíba, Piauí, Rio Grande do Norte and Sergipe. It covers about 1.5 million square kilometers, over 18 percent of Brazil's total area. In 1998, the population of the Northeast was 46 million or about 29 percent of Brazil's total population. Northeast GDP accounted for about 13 percent of Brazil's GDP and per-capita GDP in Northeast was only 46 percent of GDP in all Brazil. In 1999, the poverty rate, measured by per-capita income and the indigent poverty line, in the Northeast was about 44 percent compared to 22 percent elsewhere and still disproportionately rural $^{2}$. In contrast, the four states in the Southeast which occupy only 11 percent of land area, accounted for 43 percent of total population and around 60 percent of Brazilian GDP. Finally, the poverty rate in São Paulo is 9 percent, hence less than a fifth of the northeastean poverty rate.

The disparity between the Northeast and the Center-South of Brazil goes back centuries. Several factors, including recurrent droughts, contributed to a rapidly growing socioeconomic gap between the two regions. The relative decline of the Northeast ceased only in the 1960s when the federal Government initiated broad-based measures to support development of the region. These measures helped stabilize the Northeast economy and modernize the industrial sector.

The Northeast of Brazil over the last ten years has on a per-capita basis been growing faster than Brazil as a whole. Estimating geometric growth rate from recently released GDP data from Contas Regionais, 1985-97, Carrizosa, Fiess and Verner (2001) find that during 1985 and 1997 per-capita GDP in the Northeast region increased by 3.7 percent while per-capita GDP in Brazil increased by 3.0 percent.

Poverty remains one of the biggest and most difficult problems in the Northeast region despite efforts to fight it by the local and federal governments and civil society. In

\footnotetext{
${ }^{1}$ Wodon (2000).

${ }^{2}$ In Brazil there does not exist an official poverty line. Different authors use different poverty lines. This paper uses a caloric intake poverty line (see section 2 ).
} 
the Northeast region, the simple income picture is as follows. In 1999, Rio Grande do Norte, for example, has an average monthly household per-capita income of $\mathrm{R} \$ 173$, slightly above the northeastern average of $\mathrm{R} \$ 155$ but far below the national average of $\mathrm{R} \$ 320$ or the respective figure for São Paulo $(\mathrm{R} \$ 437)^{3}$. In 1999 , the headcount poverty ratio and the indigence poverty line, which is a low and "food only" poverty line, indicate that 39.7 percent of Rio Grande do Norte's population is poor. This is below the average for the Northeast (44.3 percent), and the lowest in the region but nearly double the headcount ratio for Brazil (22.4 percent) and about 5 times the headcount ratio of São Paulo (8.6 percent). Maranhão is the poorest state and the poverty headcount counts 52 percent of the population.

The poverty line, which includes more than food, is a little more charitable but the figures reveal that 69.1 percent of the population in Rio Grande do Norte is below this poverty line. These figures are the basic motivation behind this paper, where we analyze poverty and determine factors that may contribute to it.

The aim of this paper is to enhance for the Northeast region the understanding of: (1) the evolution of poverty over the 1970s, 1980s, and 1990s; (2) the incidence, severity and profile of poverty; (3) the main contributing factors to poverty and the volatility of these factors in the 1980s and 1990s; and (4) the public policies and instruments that can be designed to assist the poor population.

Over the past decades, three major factors affected poverty in the Northeast and Brazil as a whole, namely: (1) changes in economic activity and macroeconomic stability; (2) reduction in the fertility rate; and (3) increased urbanization rate.

Macroeconomic instability has played a key role. Since 1985, six stabilization plans have been introduced. When the fifth stabilization plan, the Collor Plan of March 1990, failed, the Brazilian economy entered one of its worst recessions in history. Only after the most recent plan was introduced, the Real Plan in July 1994, did macroeconomic stability return and inflation dropped to a record one-digit low. A year after that, in May 1995, the minimum wage was raised about 40 percent, which had a marked effect on poverty. On the one hand, the progress in reducing poverty in the Northeast has been

\footnotetext{
${ }^{3}$ Author's calculations all through this section are based on PNAD 1999 data set. All income figures are in 1997 prices.
} 
slower than in other regions in Brazil, but on the other hand, the Northeast region suffered less in terms of increased poverty during the crises in 1998.

In the Northeast, as well as in the rest of Brazil, inflation is an important actor in the drama of income and poverty as the poor generally lose - more than the nonpoor during inflationary periods. One reason is that the poor cannot protect themselves against inflation as they lack access to the financial and banking systems. Hence, the macroeconomic stabilization plans that attack inflation and successfully drive it down commonly have a positive impact on the incomes of the poor. This is also the case for the poor in the Northeast of Brazil, Rio Grande do Norte as a whole, as well as the poor in its municipalities. Hence, spatial differences in the inflation rate among regions, because they are minuscule, cannot be the sole determinant of regional differences in poverty. But, inflation does impact the overall poverty trend. Amadeo and Neri (1997) study the relation between poverty, inflation, unemployment and the minimum wage. They find that inflation affects the headcount ratio by two percent and the result is not very different across Brazil. The authors also consider the minimum wage and find that it impacts negatively on poverty. That is, when the minimum wage is increased the number of people below the poverty line decreases, hence a reduction occurs in poverty. The impact varies across metropolitan areas, for example, in Recife it is -0.18 , Salvador -0.65 , and Brazil as a whole -0.43 .

Demographic changes are linked with poverty. Barros et al. (1999) analyzes the impact of demographic changes on poverty in Brazil and conclude that these are important factors in reducing poverty disparities. The main findings by the authors are that the demographic transition benefited the least developed more than the more developed regions. And if the Northeast had the national demographic composition, poverty would be three percent points lower (Barros et al., 1999).

Also, there has been a substantial increase in the coverage of social security in Brazil in the last decade, which had a substantial impact mainly on rural poverty. The 1988 Federal Constitution established the universal right to social security and instituted special eligibility conditions for rural workers under the Regime Geral da Previdência Social (RGPS), Brazil's public pension system for workers in the private sector. Recent analysis based on the 1996-97 Pesquisa sobre Padrões de Vida (PPV) survey found that 
the proportion of rural households receiving pensions from public institutions averages 30 percent in Brazil's poorer Northeast, and 24 percent in the Southeast. Delgado (1999), Beltrao et al. (1999) and others find that the implementation of the 1988 eligibility and benefit criteria has been effective in lowering the incidence of poverty among rural households ${ }^{4}$.

Various other factors, apart from the demographic changes and the stabilization of inflation since 1994, may explain part of the poverty reduction that has occurred in Brazil. The increased globalization with the opening of the Brazilian economy together with an overvalued exchange rate in most of the 1994-99 period affected the nontradable goods sectors. After the devaluation of the Real in 1998, traded goods became more expensive and hence a relative price change occurred favoring demand of nontradables. Moreover, informal-sector employment increased, particularly in services (which are primarily nontradables). This also hints at relative price changes that favored the poor. The aggregate demand channels were also important and affected the incomes of the poor. For example, the reduction in inflation uncertainty may have caused a decline in precautionary savings and an increase in consumer credits.

Furthermore, it is generally agreed that there is a strong association between growth and poverty reduction (Dollar and Kraay, 2000). Whether growth translates into significant poverty reduction depends on various factors. The degree of inequality in the country or state matters. Poverty is more responsive to growth when income, asset, gender and education inequality is lower. Hence, more equal societies will generally grow faster.

This paper is organized in five sections. Section 2 briefly explains the data and methodology. Section 3 provides a short overview of the recent picture and evolution of poverty in the Northeast region, before focusing on more disaggregated poverty profiles. The emphasis is firmly on the characteristics of the poor, rather than on exact measures of poverty. Section 4 presents findings from probit poverty analyses and compares these over the past two decades. Furthermore, this section shows clear indications of groups that are particularly vulnerable to shocks, policy and macroeconomic changes. Finally, section 5 concludes and brings policy recommendations. Additionally, the paper includes four

\footnotetext{
${ }^{4}$ Paes de Barros, Mendonça and Santos (2000) provide detailed analysis of old age poverty in Brazil and find a substantially lower incidence of poverty for this age group. Camarano (2000) provides a detailed social profile of old age in Brazil.
} 
appendices with information for all states in the Northeast region ${ }^{5}$ : Appendix A contains a variable list, deflators and codings; Appendix B presents poverty indexes and general measures of inequality from DHB Tables as well as PNAD data; Appendix C contains poverty profiles; Appendix D contains an analysis of poverty probits in Brazil, the Northeast and individual states in the northeastern States.

\section{Data and Methodology}

This section explains and discusses the data sets applied in the analysis. Then follows a description of the poverty measures and poverty lines applied in the study.

\subsection{Data}

The vehicle for the analysis in this paper is both money-metric and non-money-metric welfare indicators constructed from available data. The data applied are from two sources: (1) the Desenvolvimento Humano no Brasil - DHB (1998), a co-production of IPEA, IBGE, FJP, and PNUD constructed from the census figures for 1970, 1980 and 1991; and (2) Pesquisa Nacional por Amostra de Domicílios - PNAD (The Brazilian annual National Household Survey) for the years 1981, 1985, 1988, 1990, 1993, 1995, 1997, 1998 and 1999. The PNAD data is an annual national household survey conducted and performed by IBGE, the Brazilian Census Bureau, in the third quarter of each year and it is derived from interviews of approximately 100,000 households. The survey began at national level in 1971 and underwent major revision between 1990 and 1992. This revision has made it difficult to obtain full compatibility of data between the PNAD concept before and after 1992; and since we do compare data across decades, this is important to keep in mind. The survey contains extensive information on personal characteristics, including information on income, labor force participation, and educational attainment and attendance. Ferreira, Lanjouw and Neri (1999) discuss shortfalls of the PNAD data and find that the PNAD underestimates incomes, and most seriously so in rural areas. Appendix A presents the data series, deflators and codings for the PNAD data and indicates differences over the 1981-98 period in the survey instrument.

\footnotetext{
${ }^{5}$ There is far more information in the appendices for other northeastern States than actually included in the text.
} 
Elbers et al. (2001) demonstrate a methodology to impute a measure of consumption, as defined in the PPV household survey, into the much large PNAD household survey. The purpose of this exercise was to estimate measures of welfare, such as poverty and inequality, defined in terms of consumption. Furthermore, the paper shed light on the question of whether the analysis of poverty and inequality based on the PNAD income indicator yields different conclusions than an analysis based on consumption. The findings show that poverty and inequality, estimated on the basis of consumption in the PNAD, tend to be much lower than estimates based on the income concept, which is not necessarily an indictment of income based analysis, however, as the two concepts of welfare are different and should not be expected to yield the same quantitative estimates. The authors demonstrates however, that differences in estimates of poverty and inequality between the PNAD and the PPV are not attributable to non-comparability of these two surveys and the PNAD consumption-based estimates are very close to those which obtain with the PPV. The paper pursued the comparability of income and consumption-based results further by examining whether there are important qualitative differences in the geographic profile of welfare across the two approaches. The paper indicate that the two reach broadly similar findings.

\subsection{Poverty measures and lines}

Poverty measures are designed to count the poor and to diagnose the extent and distribution of poverty, while social welfare functions are guides to policy ${ }^{6}$. Hence, it is worth keeping in mind that poverty measures are not necessarily an adequate guide to policy. Three commonly used measures of absolute poverty are discussed and they are applied in the following sub-sections.

The poverty measures proposed by Foster, Greer, and Thorbecke (1984) are the headcount ratio $\left(\mathrm{P}^{0}\right)$, poverty gap $\left(\mathrm{P}^{1}\right)$, and the squared poverty gap $\left(\mathrm{P}^{2}\right)$. The former is a measure of the magnitude of poverty and the latter two poverty measures assess both magnitude and intensity.

The headcount ratio is defined as the proportion of people below the poverty line. One concern applying the $\mathrm{P}^{0}$ measure is that each individual below the poverty line is

\footnotetext{
${ }^{6}$ Poverty measures are not Pareto-consistent since they do not consider the welfare of the non-poor.
} 
weighted equally and, therefore, the principle of transfers is violated. Hence, it is possible to increase social welfare by transferring money from the very poor to lift some richer poor out of poverty. $\mathrm{P}^{0}$ takes no account of the degree of poverty and it is unaltered by policies that lead to the poor becoming even poorer.

One measure of poverty that takes this latter point into account (at least in weak form) is the poverty gap measures. $\mathrm{P}^{1}$ is the product of incidence and the average distance between the incomes of the poor and the poverty line. It can be interpreted as a per-capita measure of the total economic shortfall relative to the population. $\mathrm{P}^{1}$ distinguishes the poor from the not-so-poor and corresponds to the average distance to the poverty line of the poor. One problem with the poverty gap measure is that it will increase by transfers of money from poor to less poor (who become nonpoor), and from poor to nonpoor. Furthermore, transfers among the poor have no effect on the poverty gap measure.

The $\mathrm{P}^{2}$ measure of poverty is sensitive to the distribution among the poor as more weight is given to the poorest below the poverty line. $\mathrm{P}^{2}$ corresponds to the squared average distance of income of the poor to the poverty line. Hence, moving from $\mathrm{P}^{0}$ towards $\mathrm{P}^{2}$, more weight is given to the poorest in the population.

The poverty line, used to evaluate poverty, is the indigence poverty line, which is based on the monetary value of food items only. This measure is based on the cost of a "minimum food-basket" equal to the FAO minimum caloric intake of 2,288 per day ${ }^{7}$. The poverty line is expressed in the same currency unit as the income vector ${ }^{8}$ and corresponds monthly to around R\$65 per-capita for the metropolitan area of São Paulo in 1996 prices ${ }^{9}$. The value for other metropolitan areas is adjusted by the local cost of living in accordance with the estimations of Ferreira, Lanjouw and Neri $(1999)^{10}$. The high poverty line, which includes expenses on food and nonfood items such as transportation, public services, housing, etc., equaled $\mathrm{R} \$ 132$ in 1996 (R $\$ 148.98$ in June, 1999) which corresponds to twice

\footnotetext{
7 The "lower" poverty line scales up the cost of the minimum food basket to account for non-food expenditures and is worth $\mathrm{R} \$ 131.97$ per month.

${ }^{8}$ That is the 1998 prices ruling in São Paulo.

${ }^{9}$ The food-only poverty line is given by the local value of a food basket that yields an internationally accepted caloric intake.

${ }^{10}$ The indexes for urban Northeast and the rural Northeast are 1.032056 and 0.953879 , respectively.
} 
the lowest poverty line for each region. The DHB applies half a minimum salary as the poverty line $e^{11}$.

\section{Evolution of Poverty and Income Inequality}

What happened to poverty in the last decades? This section shows that there has been tremendous diversity in outcomes in the Northeast region as well as in Brazil as a whole, across dimensions such as states, municipalities, households, and individuals. Both income poverty and nonincome poverty are considered in the analysis. Investment in human capital, such as education and health, and in infrastructure services for the poor are posited to reduce poverty. Investment in human capital reduces poverty by raising productivity, employability and wages; investment in infrastructure services for the poor, for example, water, sanitation and transportation reduce poverty by raising the time available for income generating activities and, hence, increase total income, monetary and non-monetary, of the poor. This section is organized in subsections that consider: (1) income and poverty before and after 1990; (2) education and child labor; and (3) other welfare indicators. Next, we provide a brief overview of the recent picture and evolution of poverty before focusing on a more disaggregated poverty profile.

\subsection{Income, inequality and poverty in the 1970-91 period}

In this section we apply the DHB data for the period from 1970 to 1991 . The data reveal that the average income measured in units of 1991 minimum wages has more than doubled in Brazil and the Northeast region in the 1970 to 1991 period (Table B1). However, in 1991 in the latter region the average income is barely 65 percent of the listed minimum wage (mw) while in the Southeast region and Brazil as a whole it is 177 percent and 131 percent, respectively. These figures illustrate the huge income dispersion between the Northeast and the Southeast regions. Moreover, the average citizen in Rio Grande do Norte has an income of $0.72 \mathrm{mw}$, which ties Rio Grande do Norte and Sergipe $(0.73 \mathrm{mw})$ as the states with the second highest average income in the Northeast after Pernambuco $(0.81 \mathrm{mw})$. Maranhão is the poorest state of the Northeast and has an average income of

\footnotetext{
${ }^{11}$ The different poverty lines used in sections 3.1 and 3.2 explain the differences between the levels and the similarity of the trends of the poverty indices between this section and the later ones.
} 
$0.46 \mathrm{mw}$ (Table B3 shows figures for the states in the Northeast). Even though average income in Rio Grande do Norte increased in terms of minimum wages in the 1970-91 period, it is still around 45 percent below the Brazilian average ${ }^{12}$. Furthermore, in Rio Grande do Norte as elsewhere, large differences exist among municipalities. The poorest municipality in Rio Grande do Norte is Ruy Barbosa $(0.17 \mathrm{mw})$ and the richest is Natal (1.45 mw), (Table B6) both located in the eastern part of the state.

The income inequality in Brazil is one of the largest in the world and has unambiguously increased in the 1970-91 period. This is the case for Brazil as a whole as well as for the Northeast region (Tables B1 and B3). The Theil L index measure of income inequality indicates that inequality has increased over the 1970s, 1980s, and the beginning of the 1990s in all states, and as much as 37 percent in the Northeast region, to a 0.78 level ${ }^{13}$. Rio Grande do Norte has an Theil L index of 0.74. The neighboring states Bahia, Ceará and Pernambuco have the most unequal distribution of income of all 27 states (the index reached $0.80,0.81$, and 0.80 , respectively). The municipalities in Rio Grande do Norte also show a huge dispersion in income inequality. Viçosa tops the list by a Theil L index of 0.99, followed by Antônio Martins (0.84). The least income inequality is found in Ipanguaçu and Severiano Melo (0.26).

Figure 1 reveals that the poverty ranking of the states in the Northeast has not been constant over the past three decades. In 1970, Piauí was the poorest state in the Northeast but in 1990 Maranhão had the highest headcount poverty index. Headcount poverty from the seventies to the eighties declined 45 percent mainly due to the relatively high growth rates Brazil experienced during the 1970s. This development contrasts that of the 1980s, where the lack of economic growth combined with both high inflation and various failed stabilization plans increased poverty. The high inflation and failed stabilization plans were

${ }^{12}$ The income in Bahia and Ceará are lower than in Pernambuco (around the Northeast average) and increased 89 percent and 150 percent, respectively, over the past decades.

${ }^{13}$ The Theil $\mathrm{L}$ index is a measure of inequality that is based on information/probability theory. The Theil $\mathrm{L}$ index varies between 0 (absolute equality) and 1 (absolute inequality). Like the Gini coefficient, the higher is the Theil index the more unequal is the distribution of expenditures (or incomes). The Theil $\mathrm{L}$ index is calculated as follows:

$$
L=\sum_{i=1}^{N} \ln \left(\frac{Y}{y_{i} N}\right)
$$

where $\mathrm{y}_{\mathrm{i}}$ is the welfare measure for individual $\mathrm{i}, \mathrm{N}$ is number of people in the population, and $\mathrm{Y}$ is the total of all individuals' welfare measures (i.e., total expenditure or income). 
mainly due to an unresolved fiscal deficit, leading to an economic recession in 1990 to 1991, and, hence, are important factors behind the reverse in the positive development of the headcount ratio.

Figure 1: Headcount poverty index $\left(\mathrm{P}^{0}\right)$ for the NE States, NE and Brazil (1970-91)

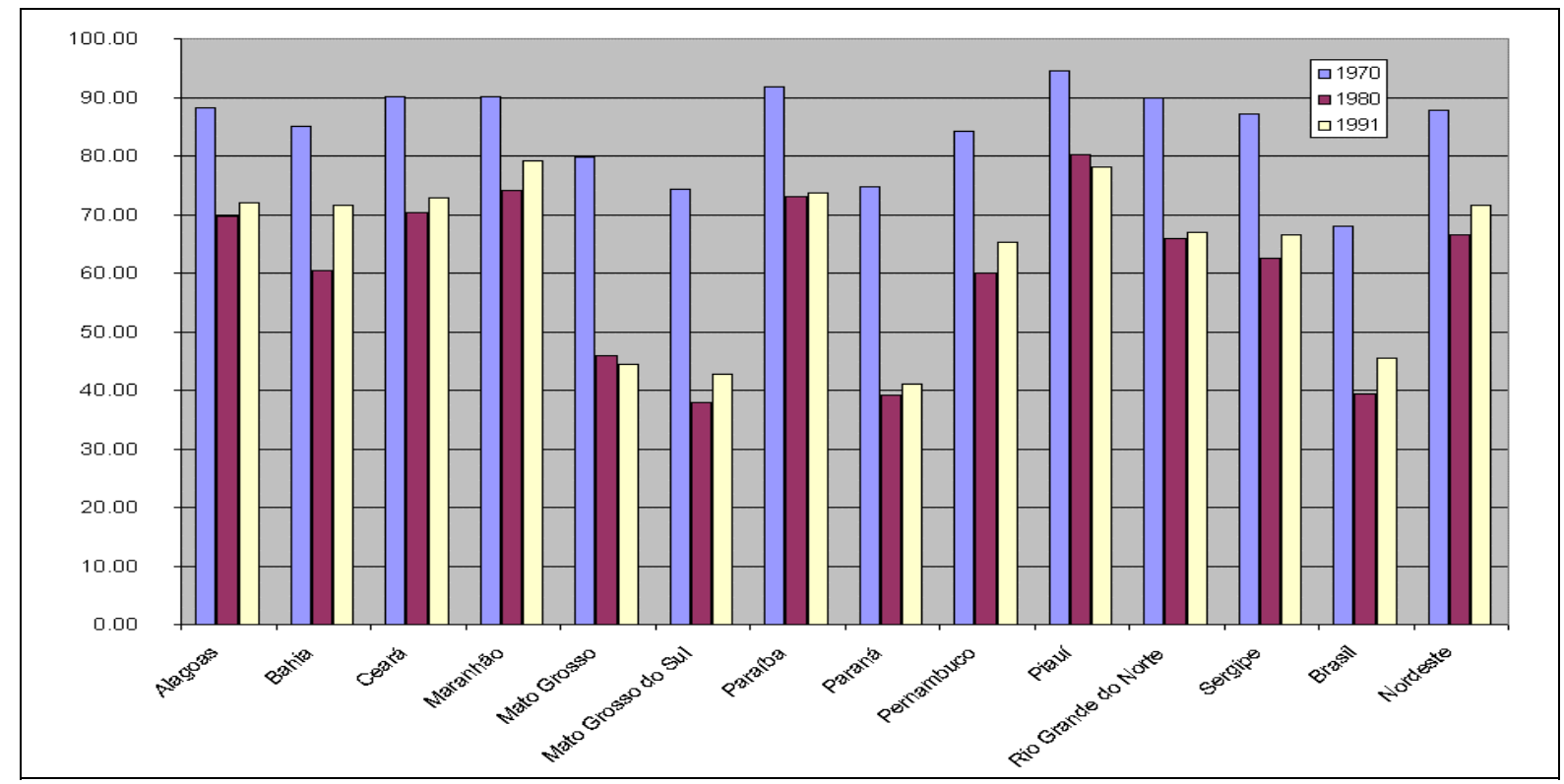

Data Source: Atlas do Desenvolvimento Humano no Brasil (1998) - IBGE.

Figure 2: Headcount poverty $\left(\mathrm{P}^{0}\right)$ for micro-regions in Rio Grande do Norte (1991)

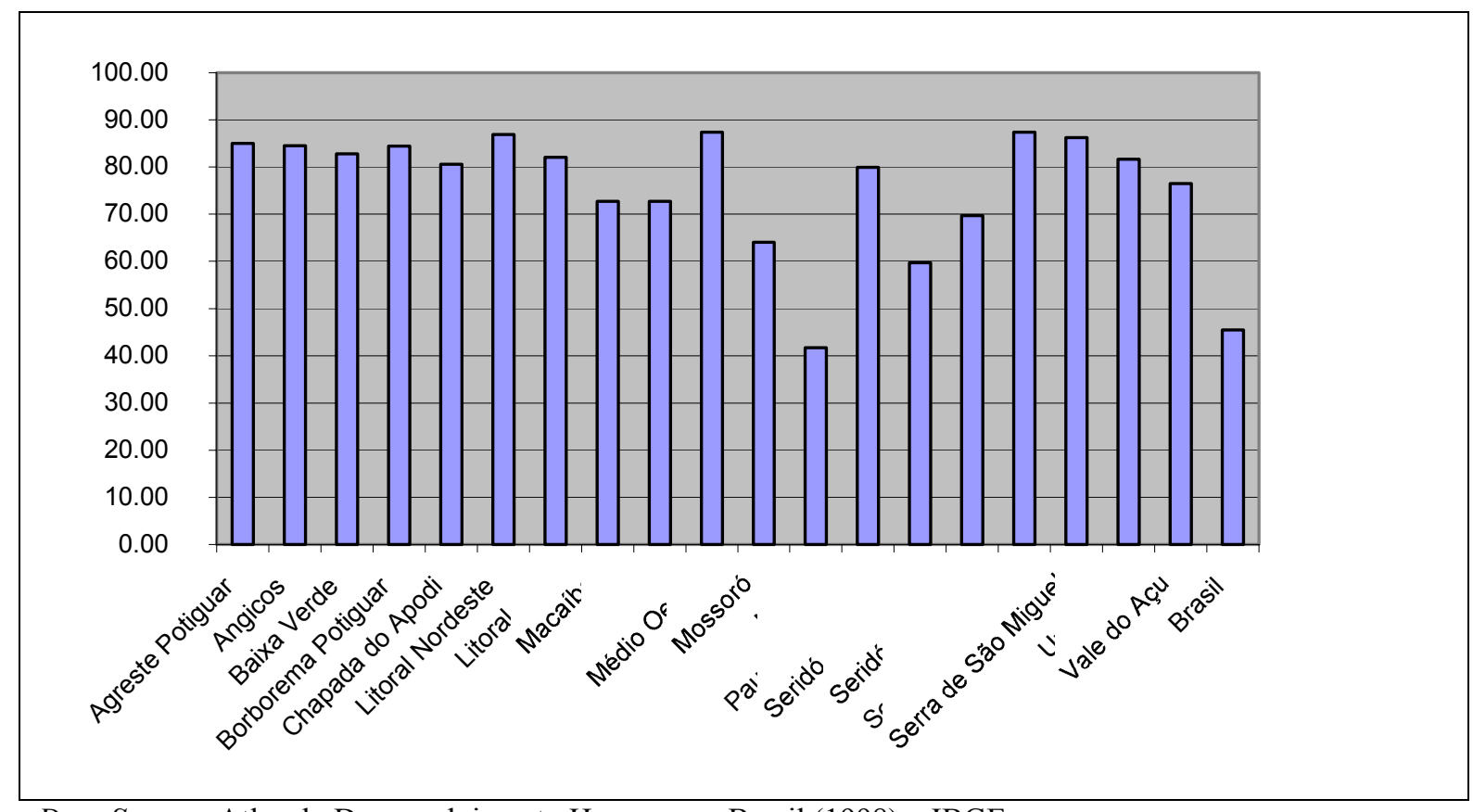

Data Source: Atlas do Desenvolvimento Humano no Brasil (1998) - IBGE. 
For Rio Grande do Norte, the $\mathrm{P}^{0}$ measure shows that 67 percent of the population are poor, which is below the Northeast average (72 percent), but still 2.3 times greater than the poverty incidence in the Southeast of Brazil in 1991 (Table B2). The difference between microregions within Rio Grande do Norte is even larger than among the macroregions and states (Figure 2). The headcount ratio shows that 87 percent of the population in Litoral Nordeste, Médio Oeste and Serra de Santana are poor, which sharply contrasts to the Natal region where 42 percent experience poverty. Not only is poverty more prevalent outside Natal but it is also deeper, as measured by $\mathrm{P}^{1}$ and $\mathrm{P}^{2}$.

Weighting larger distances from the poverty line more heavily, through the $\mathrm{P}^{2}$ measure, poverty fell in Brazil from 1970 to 1991 (Figure 3). The differences between microregions are pronounced when we give more weight to the poorest. The $\mathrm{P}^{2}$ measure indicates that poverty is 3.8 times greater in Serra de Santana than in Natal, where $\mathrm{P}^{2}$ is 0.46 and 0.12 , respectively (Figure 4 ).

Figure 3: Squared poverty gap $\left(\mathrm{P}^{2}\right)$ for the NE States, NE and Brazil (1970-91)

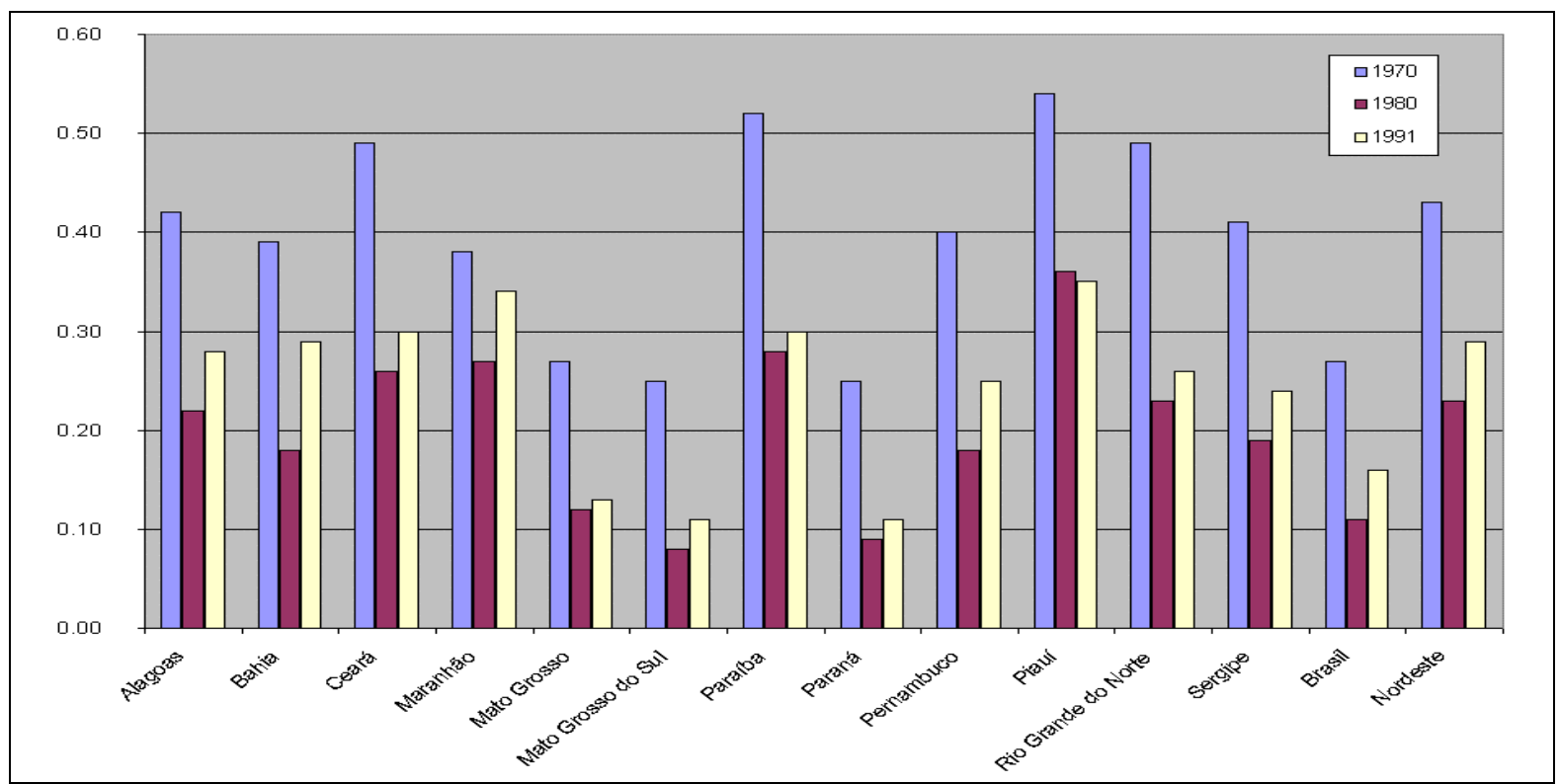

Data Source: Atlas do Desenvolvimento Humano no Brasil (1998) - IBGE. 
Figure 4: Poverty Gap $\left(\mathrm{P}^{1}\right)$ and Squared $\left(\mathrm{P}^{2}\right)$, regions in Rio Grande do Norte (1991)

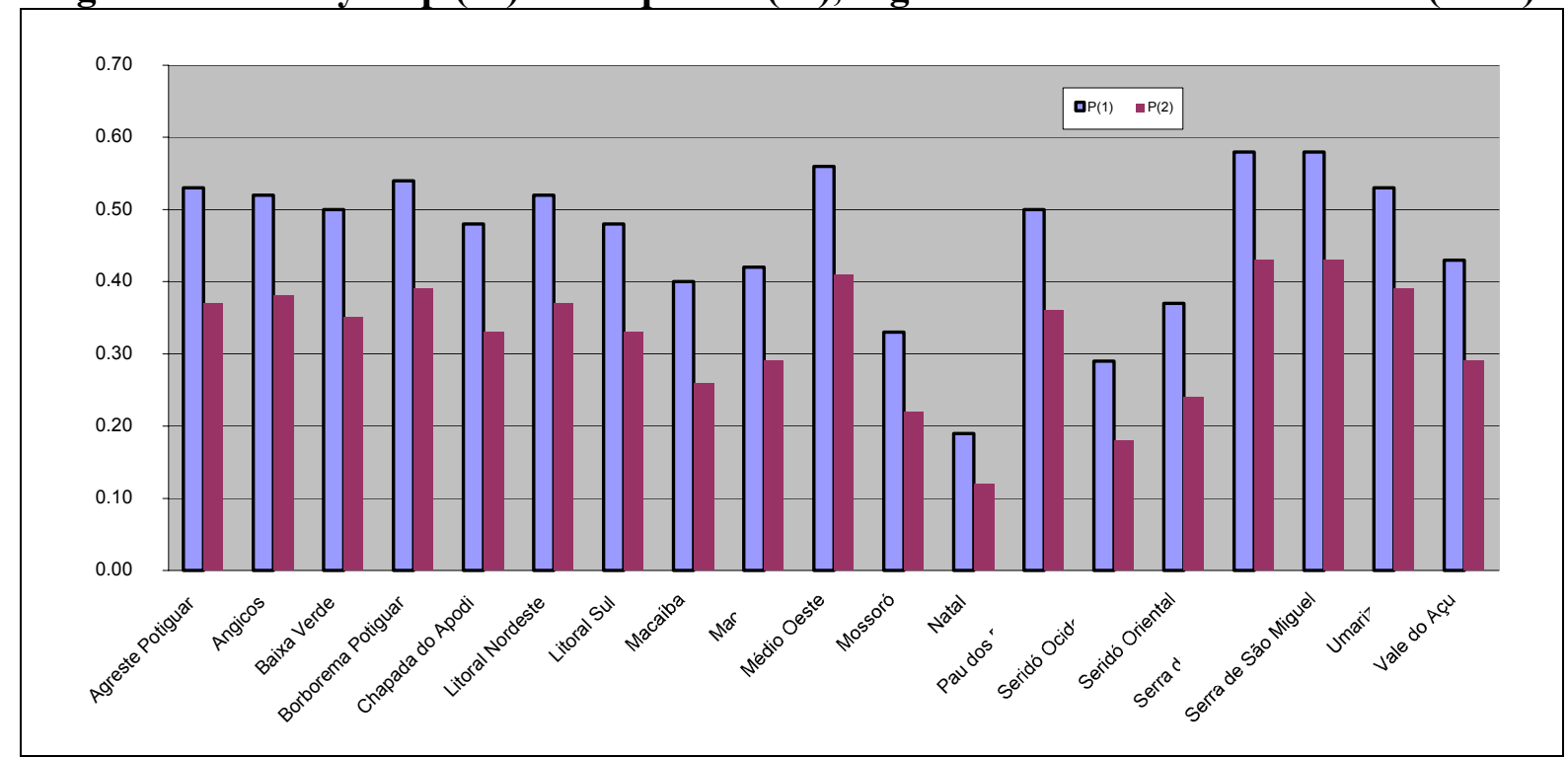

Data Source: Atlas do Desenvolvimento Humano no Brasil (1998) - IBGE.

\subsection{Income, inequality and poverty in the 1990s.}

In this section we use the PNAD data to sketch income poverty in the 1980s and 1990s. We mainly use the indigence poverty line in the analysis. The findings are presented in Appendices B and $\mathrm{C}^{14}$.

The period from 1994 and forward can be roughly characterized as a period of disinflation, which affected mean incomes and poverty in the Northeast region as well as in Brazil as a whole. The disinflation is associated with a reduction in poverty. Furthermore, in general, the poverty indexes are more affected by high inflation than are mean incomes. Hence, the poor accounted larger losses than the nonpoor during the high inflation period prior to the Real Plan launched in 1994. However, in the stabilization period that followed, the poor also experienced higher gains than the nonpoor.

As can be seen from Figure 5, at the beginning of the 1990s, poverty was at a record high in Brazil, the Northeast region, Pernambuco (the richest state of the Northeast), Maranhão (the poorest state of the Northeast) and the other northeastern states ${ }^{15}$. The major

\footnotetext{
${ }^{14}$ The coverage of Rio Grande do Norte (1,000 observations) is not as good as, for example, for Pernambuco (ca. 6,000 observations) or the Northeast as a whole (ca. 20,000 observations).

${ }^{15}$ Though, in Pernambuco and Maranhão this peak in poverty seemed to have developed a little bit later, in 1993.
} 
decline in poverty occurred in 1995, just after the Real Plan was introduced and the minimum wage was increased ${ }^{16}$. For Brazil, the Real Plan and the increased minimum wage caused a decline in poverty to a level lower than at any point during the $1980 \mathrm{~s}$, and the poverty index reveals a two percentage points reduction in the headcount in the 1981 to 1999 period (Figure 5). The Asian crisis had a small negative effect on the headcount ratios via the pressure on the currency and the higher interest rates (Figure 5 and Tables B5 to B7). For Brazil and the Northeast region, the headcount poverty ratio of household heads dropped by around 7.3 percent and 12.3 percent, respectively, in the 1993-99 period. In 1999, the incidence of poverty was 22.4 percent and 44.3 percent in Brazil and the Northeast region, respectively.

\section{Figure 5: Headcount Index: Indigence Line}

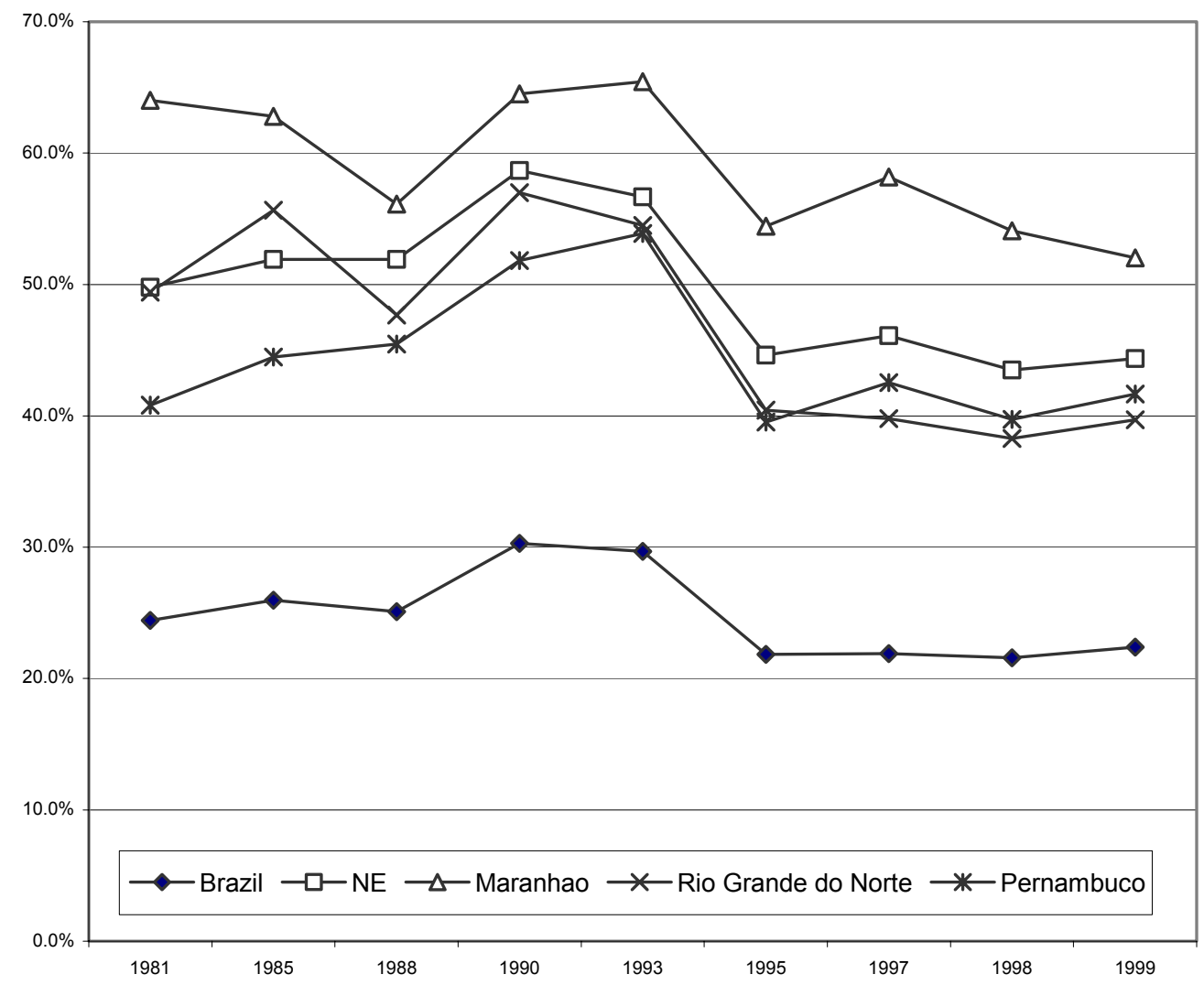

Source: Authors' calculations based on PNADs 1981 to 1999.

\footnotetext{
${ }^{16}$ In May 1995, the minimum wages were increase by 43 percent while monthly inflation was around 2 percent.
} 
The Northeast also experienced a fall in the headcount poverty ratio of household heads after 1994. In 1999, in Pernambuco, the state with the highest per-capita GDP in the Northeast, 41.6 percent of the people were poor. The respective figure is slightly lower for Rio Grande do Norte, namely, 39.7 percent, but substantially higher for Maranhão (52 percent). In the 1993-99 period, the incidence of poverty in Pernambuco, Maranhão and Rio Grande do Norte fell by 12.2 percent, 13.4 percent and 14.7 percent, respectively. Rio Grande do Norte and Paraíba experienced thus the highest reduction in poverty in the Northeast namely 14.8 percent and 17.5 percent, respectively, which is more than twice the national rate (7.3 percent).

Considering the past two decades, the headcount ratio fell in the Northeast, Maranhão, and Rio Grande do Norte by 5.4, 12.0 and 9.7-percentage points, respectively since 1981. In Pernambuco, poverty is actually slightly higher (by 0.8 percent) in 1999 than in 1981.

Figure 6: Squared Poverty Gap: Indigence Line

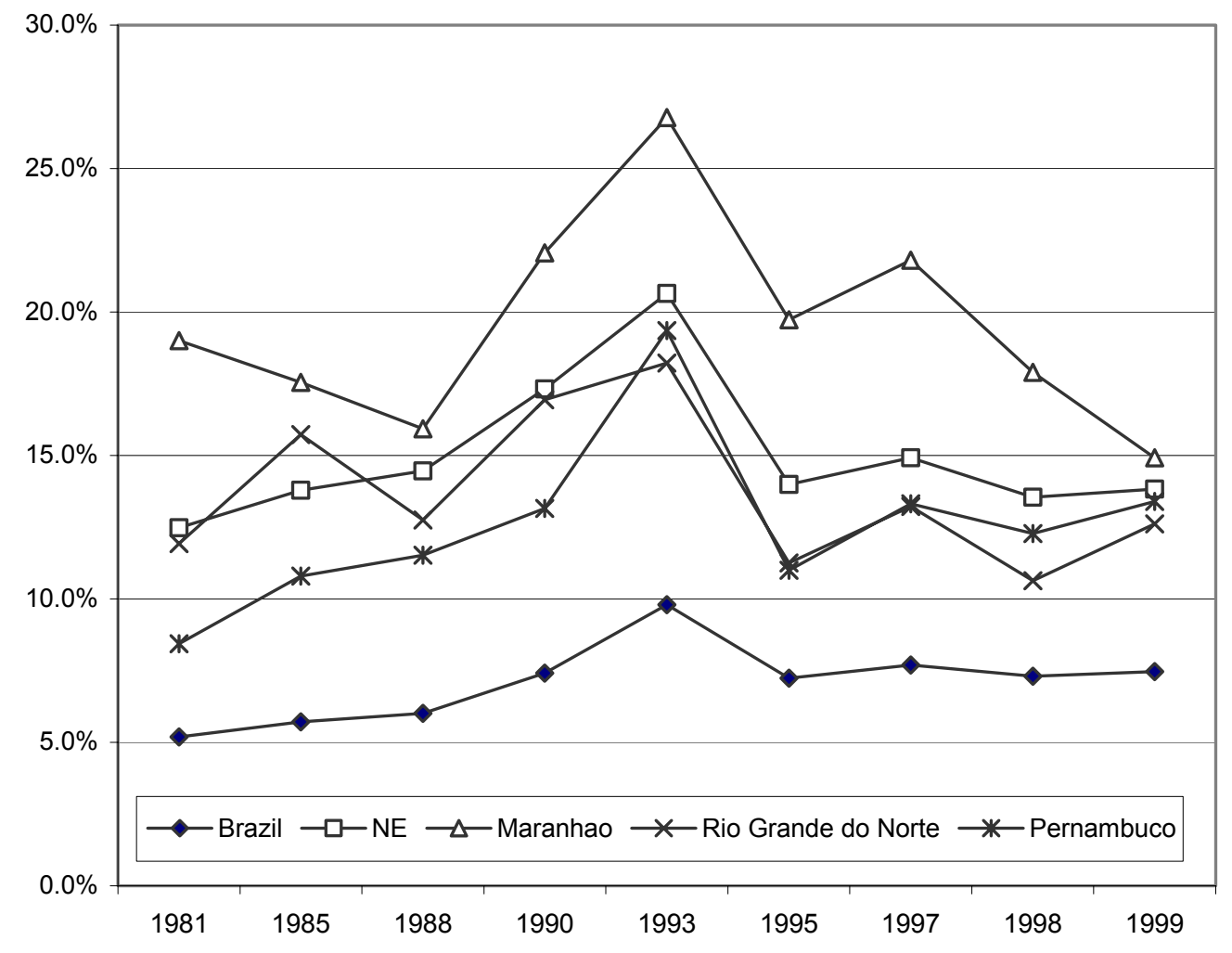

Source: Authors' calculations based on PNADs 1981 to 1999. 
Weighting larger distances from the poverty line more heavily, through the $\mathrm{P}^{2}$ measure, poverty increased from 1981 to 1999 everywhere in the Northeast, except Rio Grande do Norte and Maranhão (Figure 6). The impact of the Real Plan on poverty was largest in the Northeast, translating into a 6.7-percentage points reduction in poverty during the 1993 to 1995 period (from 0.21 to 0.14). In Rio Grande do Norte, $\mathrm{P}^{2}$ fell from 0.18 in 1993 to 0.11 in 1995 , but reached nearly 0.13 in 1999 - after an all time low of 0.10 in 1998.

What happened to income inequality ${ }^{17}$ ? One interesting observation is, that the data show that the Real Plan brought a slight increase in inequality followed by a fall. This finding contrasts with findings of Barros and Mendonza (1999) and Amadeo and Neri (1999) that show a slight decrease in inequality.

\section{Figure 7: Inequality in Brazil: Theil's L Index}

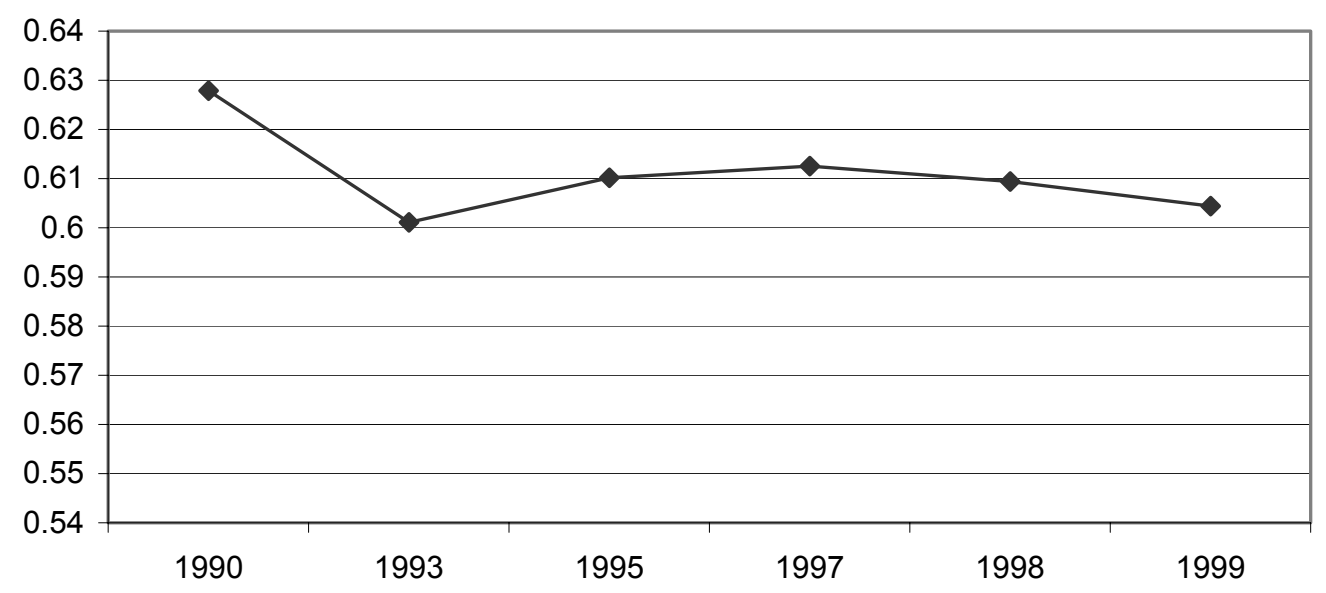

Source: Authors' calculations based on PNADs 1990 to 1999.

The reason for this is that we focus on per-capita household income, while Barros and Mendonza (1999) and Amadeo and Neri (1999) analyze individual income. This indicates slightly different developments in inequality at individual and household income level. However, taking methodological differences into account, by and large, inequality has widely remained at the same level since 1995.

\footnotetext{
17 Tables B8 and B9 display different inequality measures for Brazil and the Northeastern states.
} 
The Gini coefficients for the states reveal that incomes are more inequally distributed than two decades ago (Tables B8 and B9). In 1981, Ceará and Bahia topped the list of most unequal states in the Northeast with a Gini of 0.61 which did not change in the two decades. In 1999, the most unequal state in the region was Paraíba (Gini of 0.64). and the least unequal was Maranhão (Gini of 0.58) (Table B8).

\subsection{Poverty profile}

In the following, we partition the population based on characteristics of the household head and provide a more disaggregated poverty profile (Appendix C for all the NE States (Tables C3-C12), NE (Table C2), Brazil (Table C1) and for references São Paulo (Table C3)). In the following text we give an example of one state, namely, Rio Grande do Norte (Table C7), where the figures reveal a large difference in the levels of well-being among different groups, particularly between mulatto- and white head of households. The headcount poverty ratio reveals that 15 -percentage points more mulatto-headed households are poor than white-headed households, or 45 percent and 30 percent, respectively. Hence, the white population is, on average, at considerable smaller risk of poverty than their black or mulatto cohabitants. It is feasible that some of it works through skills and educational attainment or demographic choices. Verner (2000) finds that large wage differentials are at play between white and non-white wage earners in the labor markets in Rio Grande's neighboring state Pernambuco. Below, we elaborate this finding by including and, therefore, controlling for other attributes in the poverty analyses, to understand the mechanisms through which ethnic origin affects household poverty outcomes.

The age of the household head displays a vindicated and perceptible link with poverty incidences. The older the household head the lower the incidence of poverty. In 1999, 60 percent of the households headed by a person younger than 25 years of age are

poor. This compares to the age group above 65 years of age where only 17 percent are poor and the reduction in the headcount ratio has been substantial since 1993 (22 percent). Furthermore, the latter group has the highest average income of any age group.

Usually, the level of education is the most important determinant of poverty. The headcount for household heads who are literate is 34 percent, the headcount for illiterate household heads is with 52 percent significantly higher. Typically, a negative relationship 
exists; hence, when the level of education attainment increases the headcount poverty ratio falls. This pattern is evident in Brazil as a whole and also in most northeastern states, however, this is less evident in Rio Grande do Norte. There appears to be little difference in poverty headcount indices between household heads with no education and household heads with completed primary education. This picture might be clouded by a relatively small sample size in these groupings. Nevertheless, we can observe that household heads with completed secondary education (22 percent are poor) are much better off than their counterparts with only primary education (47 percent are poor).

As regards labor status, informal workers (sem carteira assinada) have one of the largest incidence of poverty in Rio Grande do Norte and the Northeast. The headcounts are 56 percent and 33 percent for informal and formal workers, respectively. The labor category contributing the largest share to overall poverty are employees, which seems unusual, since for the Northeast as a whole the self-employed are the poorest.

The figures of sector of occupation reveal, not surprisingly, a high incidence of poverty among household heads engaged in agricultural activities (58 percent). Furthermore, service sector workers (29 percent) are less likely to see their households in poverty than industrial workers (46 percent). The least likely to be poor are public sector workers (18 percent). These figures indicate that the poverty incidence and severity profile for labor occupation, mainly agricultural sector occupation, is a cause for concern with respect to poverty and welfare. But, a conditional analysis such as probit poverty regressions, is needed before further conclusions can be made.

In Rio Grande do Norte the majority of the poor live in the rural areas, where nearly 54 percent live on less than the poverty line measure for food necessary to obtain sufficient calories. The figure for the urban area is 34 percent. Since 1993, poverty in rural areas has been reduced by impressive 12-percentage points and in urban areas by 15percentage points. This seems to suggest that the Real Plan and state policies have benefited urban areas slightly more than rural areas.

We find that male- and female-headed households only differ marginally in the extent to which they are likely to be poor ( 39 percent and 41 percent, respectively). The male headed households experienced a lower reduction in poverty (13 percent) as compared to female-headed households (18 percent) since 1993, a findings that is not 
confirmed for the Northeast as a whole. These income poverty figures are, however, only part of the story of factors that impact a poor woman's well being. Furthermore, the data do not reveal anything about domestic violence and other types of discriminations that women often face.

\subsection{Education}

The Northeast is educationally disadvantaged as compared to the rest of Brazil. Disparities within the region and states as well as amongst poor and non-poor are dramatic. Based on PNAD data from 1981 to 1998 for the total active population (15 to 65 year old), we find that average years of completed education (effective education) of the total active population increased by 1.7 years from 4.5 years in 1981 to 6.2 years in 1998. Average effective education of the active population in Brazil with a per-capita family income below the indigence line increased by a slightly lower rate (by 1.5 years) from 2.2 years in 1981 to 3.7 years in 1998. In 1998, average effective education was highest in Distrito Federal (8.1 years) followed by São Paulo (7.3 years) and lowest in Piaui (4.1 years). In 1998, Rio Grande do Norte and Pernambuco had the highest average effective education in the Northeast. Average effective education of the total active population in Rio Grande do Norte increased by 1.7 years from 3.5 in 1981 to 5.2 years in 1998. Average effective education of the active population in Rio Grande do Norte with a per-capita family income below the indigence line increased the same rate (by 1.7 years) from 2.0 in 1981 to 3.6 years in 1998.

Nevertheless, compared to the situation in the 1970s and 1980s, the disparity between education levels in the Northeast and Brazil have narrowed only a little. The literacy rate of adults increased by 25-percentage points from 46 percent in 1970 to 71 percent in 1996, the literacy rate in the Southeast increased over the same time span from 77 percent to 91 percent (the nationwide figures for 1970 and 1998 are 67 percent and 85 percent respectively). Even though adult literacy occurred at a faster rate in the Northeast, it is striking, that in 1996, the literacy rate in the Northeast had not even reached the level of literacy of the Southeast of 1970. Further, our analysis of PNAD shows that average effective education of the poor in São Paulo (5.1 years) nearly equals the average effective education of the non-poor in Rio Grande do Norte (5.2 years). 
The increased investment in schooling by federal and state governments in the Northeast in the beginning of the 1980s seemed to have been successful. The lack of school attendance in Rio Grande do Norte (and the Northeast) are due to low school attainment by parents more than poor quality of schools in the region (Barros, Firpo and Mendoça, 1999). Furthermore, findings by Barros and Mendoça (1998) show that teachers in Rio Grande do Norte have completed 10.4 series while the average for the entire country is 10.9 series (the respective figure for São Paulo is 13.0). The difference of salaries of teachers in Rio Grande do Norte and São Paulo is substantial. Average earnings of teachers in Rio Grande do Norte and São Paulo are 3.1 and 9.4 (1990) minimum salaries, respectively. The national average is 4.8 (1990) minimum salaries. The large difference in teacher incomes however also reflects the fact that 71 percent of teachers in São Paulo have some degree of higher education, the respective figure for Rio Grande do Norte is 23 percent.

School attendance has improved substantially over the last decades in Brazil. In 1998 (IBGE Social Indicators, 1999) only 5 percent of the 7 to 14-year-olds did not go to school. The respective figure for the Northeast and Rio Grande do Norte is 8 percent. School enrollment for secondary age children (15 to 17-year-olds) is much lower, 23 percent (27 percent, 31 percent) of this age group do not attend school in Brazil (Northeast, Rio Grande do Norte). While there appears to be only a slight urban-rural difference for 7 to 14-year-olds, this gap widens for 15 to 17 -year-olds. Twenty percent (23 percent, 23 percent) of secondary school-age children do not go to school in urban areas of Brazil (Northeast, Rio Grande do Norte), while the respective figures for the rural areas are 35 percent, 35 percent and 39 percent. However, we have to keep in mind that these figures represent school attendance rates (total enrollments by age group independent of being adequate or not). 


\section{Figure 8:}

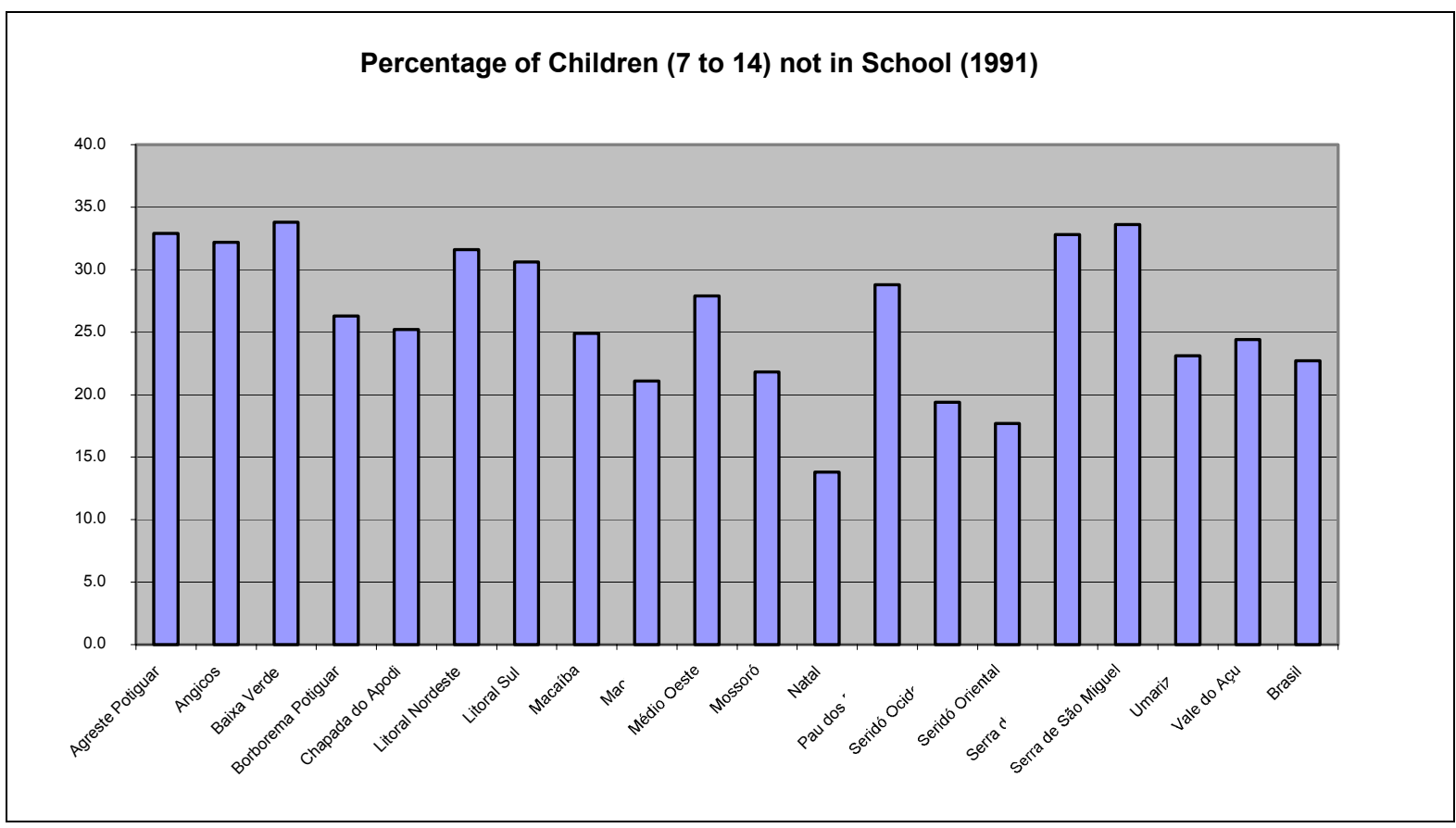

Source: Atlas do Desenvolvimento Humano no Brasil (1998) - IBGE.

\subsection{Health indicators}

In the following, we consider two health indicators namely the infant mortality rate and life expectancy at birth ${ }^{18}$. The infant mortality rate has been heavily reduced over the past decades throughout Brazil; but as figures for 1998 show, it is still very high in the Northeast -58 deaths per 1000 live births ${ }^{19}$ compared to the country's average of 36 . Again, regional differences are striking: Alagoas is the state with the highest incidence of infant mortality, namely 72 deaths per 1,000 live births, Rio Grande do Sul has the best record, with 19 deaths per 1,000 live births. In Rio Grande do Norte 55 out of 1,000 die at birth. DHB data for 1991 indicate that theses disparities persists at microregions. Within Rio Grande do Norte, Macao tips the scale at 169 deaths before the age of one out of 1,000 live births. This sharply contrasts to Natal's 59 deaths.

\footnotetext{
${ }^{18}$ The analysis in this section is based on Sinteses de Indicadores Sociais from IBGE, 1999.

19 "Síntese de Indicadores Sociais" (Table 2.1 IBGE, 1999).
} 
Figure 9: Life Expectancy at Birth - 1996

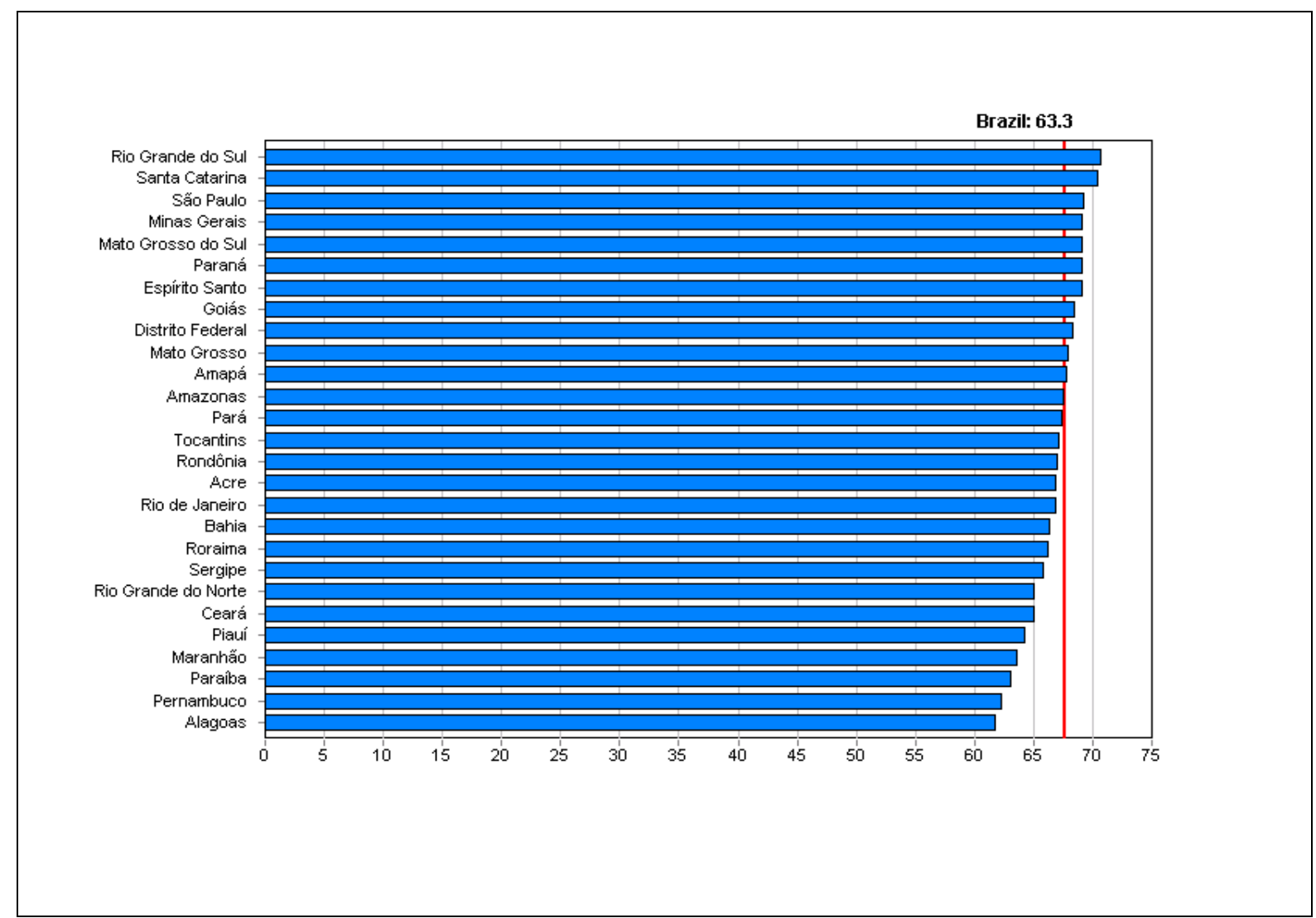

Source: Atlas do Desenvolvimento Humano no Brasil (1998) - IBGE.

Also, the life expectancy at birth, that is the number of years a person can expect to live when born, has markedly improved since 1970, but the differences between states are substantial (see Figure 9). In Rio Grande do Norte a newborn can expect to live to the age of 65 as compared to 70 years in the South.

\subsection{Housing characteristics and access to services}

The patterns underlying home ownership in Brazil seem to be different from most developed countries where rich households own their homes and pay mortgages and poorer ones rent their homes (Tables $\mathrm{C} 1-\mathrm{C} 13$ ). On average, the rate of home ownership appears to be larger amongst the poor than the rich. In Brazil in 1998, home ownership in urban areas amongst the extreme poor (per-capita income of less than half a minimum salary) was 78 percent, while 70 percent of the rich (per-capita income of more than 5 minimum salaries) owned their houses and renting accommodation was nearly twice as common amongst the 
rich (21 percent) than the poor (12 percent). The fact that the richest people also rent is not a new finding, as Ferreira, Lanjouw and Neri (1999) find the same for Brazil as a whole using the PPV data.

The access to services related to homes is very unequally distributed as the poorer households receive fewer services than the richer ones. Access to services such as piped water and sewerage system as well as organized waste disposal are other indicators revealing standards of living. Figures for 1998 show that in the Northeast region only 31 percent of privately owned houses in urban areas had piped water, adequate sewage systems and organized waste collection. The respective figure for Brazil is 62 percent and for the Southeast 85 percent. The distribution of these services amongst poor and non-poor is even more unequal across regions. Comparing access to services for the extremely poor (per-capita household income of less than half a minimum salary) across regions, we find that households with a per-capita income of less than half a minimum salary face substantially worse living conditions in the Northeast than in the Southeast. Only 18 percent of extremely poor households have adequate access to water, sewage and waste services, compared to 64 percent in the Southeast. Across the Northeast, the best living conditions are found in Bahia, where 41 percent of the total population and 25 percent of the extremely poor households have acceptable access to water, sewage and waste services $^{20}$. The living conditions for households in Rio Grande do Norte are slightly below the average of the Northeast, 29 percent of all privately owned houses have access to adequate water, waste and sewage services, the respective figure for the extreme poor is 21 percent.

The majority of households in Rio Grande do Norte (51 percent) have access to piped water, but only 40 percent of the poor have access (Table C7). Furthermore, only 39 percent of the poor households have access to electricity, as compared to 65 percent of the total population. Additionally, 76 percent have no access to disposal of sewage through the main sewage system. They use alternative means, for example, drains (28 percent) and direct dumping into lakes and rivers (45 percent).

\footnotetext{
${ }^{20}$ The best living conditions in the Northeast can be found in the metropolitan area of Salvador, where 66 percent of privately owned houses have access to adequate water, waste and sewage services. Synthesis of PNAD, IBGE, 1999.
} 


\section{Determinants of Poverty ${ }^{21}$}

Many individual characteristics such as education, experience and labor market association are important correlates of poverty and the dynamics thereof. In this section, We investigate the marginal impact of each individual attribute on the likelihood that a household fall below the poverty line of absolute poverty. The analysis is undertaken applying probit regression techniques. Ferreira, Lanjouw and Neri (1999) use PPV data in a similar study, and these authors perform the study for Brazil as a whole and for one year, which gives a good but static picture of the situation in Brazil. Here the analysis is more dynamic in nature as it is based on nine PNAD data sets from the years 1981, 1985, 1988, 1990, 1993, 1995, 1997, 1998 and 1999. Hence, nine poverty analyses are performed for the individual states in the Northeast region and also for the all Northeast. This allows for an evaluation of the evolution of poverty over time and the most important variables determining poverty. This analysis reveals: (i) conditional correlation between poverty and characteristics of household heads; (ii) information about the volatility of the impact of the attributes on the likelihood that a household experiences poverty during the 1980s and 1990s; and (iii) information about groups that are particularly vulnerable and changes thereof over the past decades. The findings are presented in appendix D.

We regress the status of the household-poor or nonpoor - on relevant individual and household characteristics. The income concept used for the dependent variable is average per-capita income and the poverty line applied is the indigence. The dependent binary variable takes the value of one when income is below the indigence line and zero otherwise. The vector of independent variables includes: (1) attributes of household head: gender; ethnic origin; education; experience and labor market connection (whether the household head works, the type of relation with the labor market, sector of employment, and tenure in the job); (2) family variables: size and age of its members; (3) housing

\footnotetext{
${ }^{21}$ Appendix D contains a significance analysis for poverty probits for Brazil, the Northeast and individual states in the Northeast based on PNAD 1999 data.

As the results of the individual state-probit regressions are similar to the results of appendix D, they are only reported in graphical form in Figures 10 to 15 for the Northeast and Rio Grande do Norte in order to preserve space.
} 
characteristics: durability of walls and roof; (4) access to services, such as piped water, electricity, waste disposal and sanitation; (5) wealth variables such as owning or renting the home and ownership of refrigerator; and (6) rural versus urban location. The marginal effect of a change in each independent variable on the probability of being poor is measured by the parameter estimate of this variable.

We interpret these poverty profile probit regressions as descriptive and do not infer anything in terms of causation. This is important to keep in mind particularly when considering the wealth indicators, but less so with education as household heads obtained their education level prior to the interview period. In the following two subsections we discuss broadly the differences between: first the NE and the rest of Brazil, and second the $\mathrm{NE}$ and its states in 1999. In the third section we go more into detail on the determinants of poverty in a state and the NE region in the past two decades.

\subsection{Regional Differences in Poverty - a nested approach}

Regional differences in probabilities of experiencing poverty, require policy makers to address these differences. In this section we try to assess regional differences in the likelihood of being poor between (1) the Northeast of Brazil and other areas in Brazil; and (2) individual states in the NE. For this purpose we estimate two probit regressions ${ }^{22,23}$. For the Northeast versus Brazil probit specification, we interact all the independent variables with a 0-1 dummy for the NE. For the Northeast versus its states we limit our sample to the NE and interact all the independent variables with a dummy for each individual state in the NE. This probit specification is run separately for all nine states in the NE.

\footnotetext{
${ }^{22}$ Probit coefficients are not easy to interpret, since they do not represent the standard marginal effects represented by linear regression coefficients. We therefore chose to present marginal effects rather than Probit coefficients. The marginal effects for a household head $i$ in the Probit model are simply given by:$$
m_{i}=\frac{d \operatorname{Pr}\left(y_{i}=1\right)}{d x_{i}}=\phi\left(x_{i} \beta\right) \beta
$$

This represents the marginal changes in probability that a household head $i$ is poor due to changes in the underlying regressors. In order to summarize representative marginal effects, the changes are evaluated at the mean of the data. Since similar conditions apply for marginal effects as for Probit coefficients, the same tests for the positivity, negativity or significance can be applied.

${ }^{23}$ OLS regressions confirm the results of the probit analyses.
} 
The coefficients of the probits are interpreted as follows. In the case of the NE versus Brazil specification, the coefficient for, for example, rural measures the probability of being poor for a household head residing in a rural area in Brazil. Then for a household residing in the NE the probability of being poor when residing in the rural area can be calculated by adding the coefficients of rural, NE and NErural, (i.e. rural interacted with a dummy for NE). If the NE-interacted dummies are not significant, we can conclude that there is no statistical difference in the likelihood of being poor for a person residing in the NE compared to other parts of Brazil for that particular variable. As such, the NEinteracted coefficients measure a NE-specific premium or discount on the probability of being poor associated with different individual characteristics. Insignificant differences in the probability of experiencing poverty across regions, indicate that a homogenous, crossregional strategy for fighting poverty is adequate. The data used in this section are the PNAD household survey from 1999.

\section{Northeast versus Brazil}

From Table D1 we observe that the likelihood of being poor differs in many respect in the NE from the rest of Brazil. The findings reveal that in 1999 a Nordestino is 24-percentage points more likely to be poor than other Brazilians. Furthermore, most NE-specific coefficients are significantly different from zero which indicates that the NE is different from the rest of Brazil. Given the fact, that poverty in the Northeast is nearly double the Brazil-average, this finding is not surprising.

The main difference in poverty between the Northeast and the rest of Brazil is explained by the NE dummy and not by individual characteristics. This indicate that these are regional as well as individual characteristics that are different across regions in Brazil, apart form the ones included in the analysis that are important. For example, poverty among women, for example, is higher in the Northeast than in the rest of Brazil, however, as the NE interacted dummy for female is not significant, this difference in poverty cannot be attributed to differences between women in the Northeast and women in the rest of Brazil. The difference is due to that the NE in general is more disadvantaged, which is measured by the NE dummy. 
The same way of reasoning leads to the conclusion that more skills or employment in any sector do not directly contribute neither more or less to poverty in the Northeast. But compared to the rest of Brazil, more skilled workers are poorer in the NE because of other regional specific characteristics.

Some regional differences are however noteworthy and in particular so are the NE specific coefficients on human capital. While household heads with completed tertiary education in Brazil (excluding the Northeast) are 12-percentage point less likely to fall into poverty than household heads with no education, tertiary education in the Northeast pays off more in relative terms. Household heads with tertiary education in the Northeast, though 4-percentage points more likely to be poor when compared to uneducated household heads in Brazil as a whole, are 20-percentage points less likely to fall into poverty when compared to the uneducated population in the Northeast. These findings may indicate that higher education is still a relative scare asset in the NE of Brazil.

Blacks and mulattos are 22-percentage-points more likely to be poor in the NE than black and mulattos in the rest of Brazil, 3-percentage-points more likely to be poor than whites in the NE and 27-percentage-points more likely to be poor than whites in the rest of Brazil.

Household heads in rural areas in the NE are 22-percentage- points more likely to be poor than rural household heads in the rest of Brazil and it appears again to be the NE dummy that mostly accounts for this difference. Furthermore, the rural household heads in the NE are 27-percentage points more likely to be below the indigent poverty line than urban households in the rest of Brazil.

Formal sector workers, i.e., with carteira assinada are slightly more likely to be poor in the NE than formal sector workers in other parts of Brazil, controlling for other characteristics. Finally, family characteristics are important for the likelihood of being poor. Larger households in the NE are more likely to fall into poverty than smaller households in the NE and the rest of Brazil. However, the presence of young children below the age of five and older children between five and fifteen years of age are less likely to be poor in the NE than households with no children in these age groups living in the NE Brazil. However, compared to the rest of Brazil households with children are more likely to be poor. 


\subsection{Individual States in the Northeast versus all Northeast}

This section focuses on the NE and investigates northeastern state-specific discounts and premia on the likelihood of being poor (Tables in appendix D). As a general observation, the likelihood of being poor in an individual state in the NE does not differ much from the $\mathrm{NE}$ in general. In the following we will discuss statistically significant differences. The state dummies (dummies not interacted with specific characteristics) are statistically significant but different from zero only for Piauí and Bahia, indicating underlying differences in institutions, macro variables such as capital as well as other individual characteristics and culture are important but not controlled for. For Piauí, the state dummy is strongly significant and positive, while the state dummy for Bahia is strongly significant and negative, implying that household heads in Piauí are more likely to become poor than household heads elsewhere in the Northeast region. Household heads in Bahia are less likely to be poor than in the rest of the NE. Rio Grande do Norte and the other states in the region are not statistically significantly different from the NE as a whole.

Rural household heads in Maranhão and Ceará are 5- and 20-percentage points, respectively, more likely to be poor than other rural household heads in the NE.

Regarding educational variables, we find that household heads in Alagoas with completed secondary education are 24-percentage points less likely to be poor than household heads with a similar educational profile in other northeastern states, while household heads in Ceará with some primary, completed primary and completed secondary education are 15-, 18- and 17-percentage points more likely to experience poverty than household heads with equivalent educational levels in other states of the NE which may indicate that education is of lower quality in this state compared to other states in the NE. We observe no state-specific differences in the impact of education on poverty for the other states in the NE.

\subsection{Rio Grande do Norte and the Northeast (1981-99)}

In this subsection we focus on one state, Rio Grande do Norte, and compare it to the Northeast as a whole while going more into detail then in the previous two sections, as we discuss the development over the past two decades. 


\subsubsection{Education}

In the Northeast region and its states, the most important factor contributing to the likelihood of a household being poor is completed level of education by the household head. That is, the more education a household head has completed the lower the probability of earning an income, that takes the household below the absolute poverty line. Education variables are strongly, statistically significant and negatively correlated with the probability of being poor at all levels of education starting with the first part of primary education. Furthermore, this is the case for all eight years for both Rio Grande do Norte and the whole Northeast region. Controlling for other variables, the impact of educational attainment is quantitatively the largest of all included explanatory variables. Moreover, the negative effect of education on poverty is increasing with the level of completed education of the household head. Put differently, the more completed education the less likely it is that the household experience poverty. ${ }^{24}$

Figures 10a and 10b plot the education parameter estimates for the 1981-99 period for Rio Grande do Norte and the Northeast. ${ }^{25}$ Findings reveal that the impact of having completed primary education on the likelihood of being poor has been rather constant over the 1980s and 1990s. For completed high school education, the magnitude of estimated impacts is larger than of primary education. Furthermore, for Rio Grande do Norte and the other individual states, the impact is closely linked to developments in the Brazilian economy. The effect on poverty of completed education was larger during economic upturns such as after the implementation of the Real Plan and low during recessions such as during the Collor Plan years and the Asian crisis. Furthermore, Figure 10a shows that the impact on poverty of tertiary education is significantly and numerically larger, hence more poverty reducing than that of secondary education. Furthermore, the pattern of development is rather different for higher education, as it is less procyclical than is primary and secondary education. The largest effect of tertiary education on the probability of experiencing poverty was during the stabilization and post devaluation in 1985 . The

\footnotetext{
${ }^{24}$ Ferreira, Lanjouw and Neri (1999) using PVV data in their analysis of Brazil as a whole also find that education is the central personal attribute determining the likelihood that a household experience poverty using PVV data in their analysis of Brazil as a whole.

${ }^{25}$ The probit parameter estimates and standard deviations for each of the nine years are available from the authors upon request.
} 
findings for the Northeast are presented in Figure 10b and indicate that in this region the likelihood of experiencing poverty is less procyclical for secondary education than in Rio Grande do Norte, albeit the impact on poverty being about the same in magnitude, and furthermore, hardly any difference exists between tertiary education between Rio Grande do Norte and the Northeast region.

\section{Figure 10a: Impact of Education for Rio Grande do Norte ${ }^{26}$}

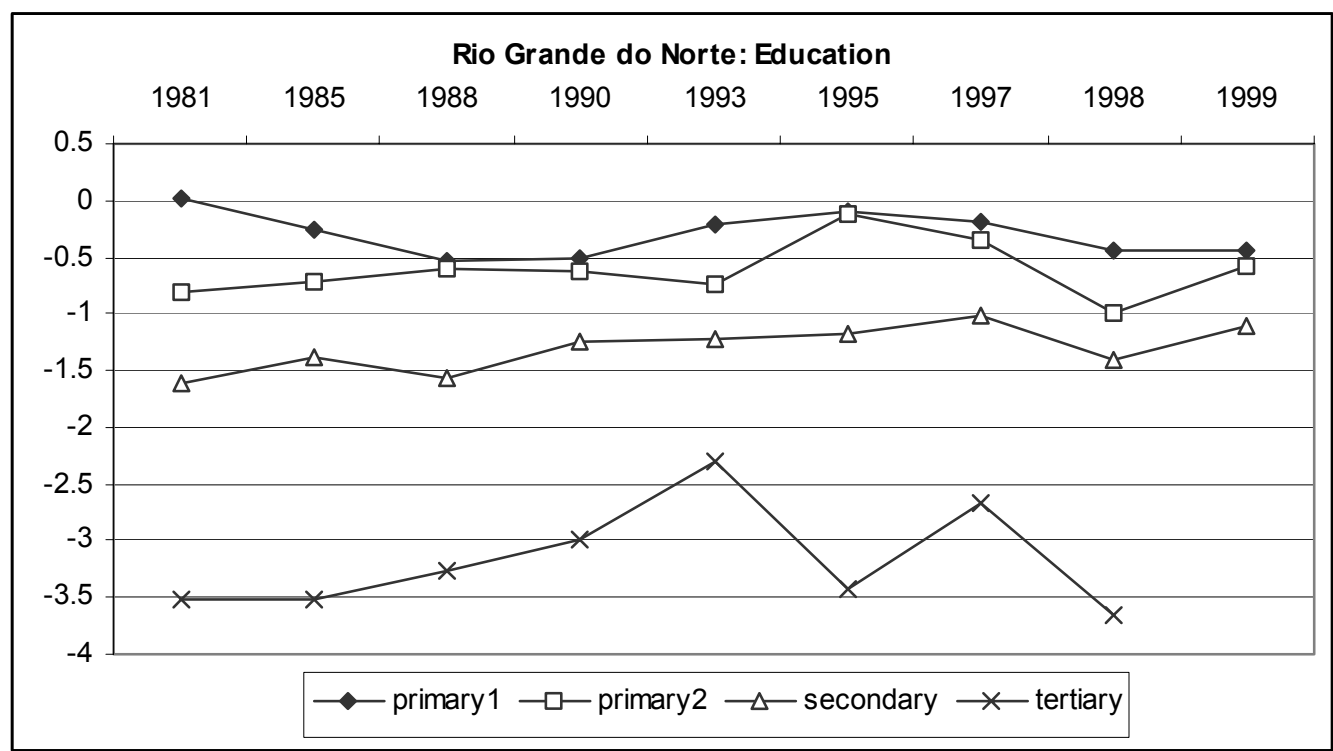

Source: Authors' calculations based on PNADs 1981 to 1999.

Note: Figures are based on probit coefficient estimates for the education variables.

\footnotetext{
${ }^{26}$ No observation available for tertiary education in 1999.
} 


\section{Figure 10b: Impact of Education for Northeast}

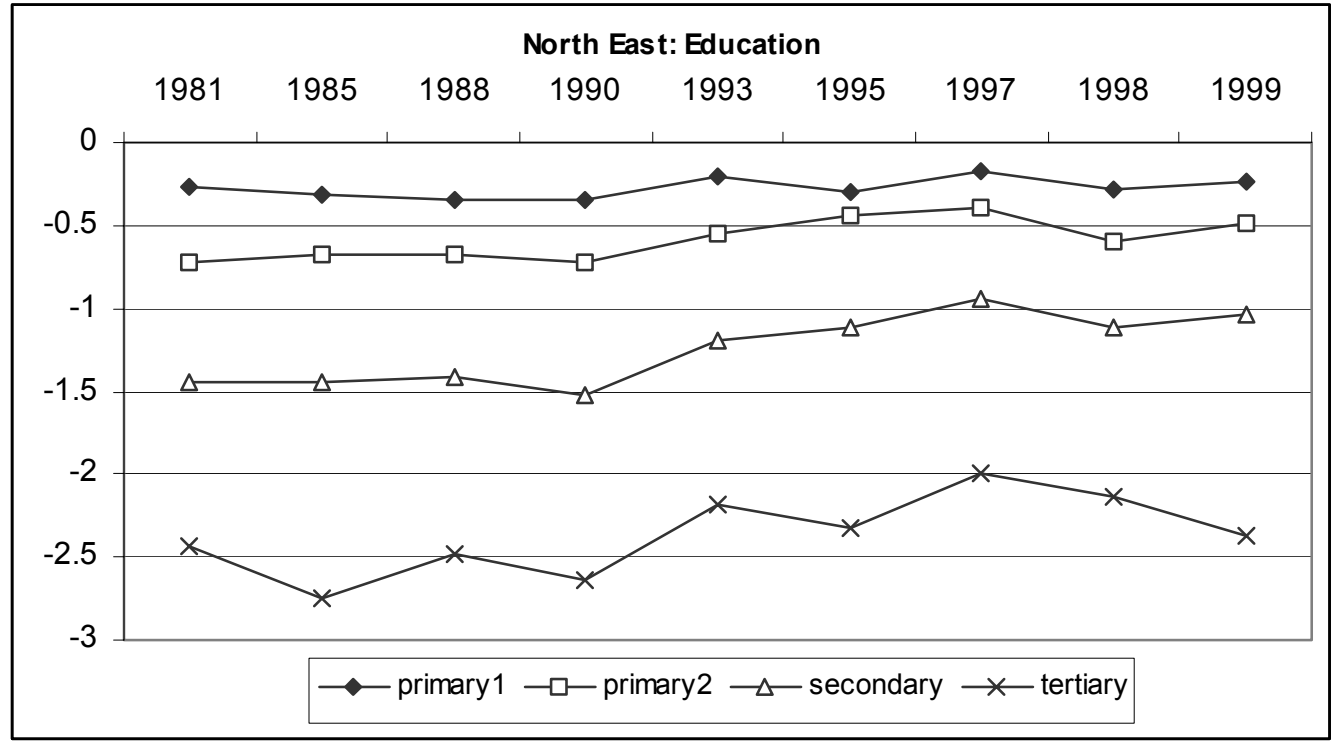

Source: Authors' calculations based on PNADs 1981 to 1999.

Note: Figures are based on probit coefficients estimates for the education variables.

\subsubsection{Gender}

The gender of the household head makes a statistically significant difference for poverty. Female-headed households have a much larger likelihood of being poor than male-headed households even, when we include other covariates in the analysis, such as labor market connection, education, etc. This finding shows that one should be careful in putting too much emphasis on unconditional poverty profiles alone. That is, comparing unconditional means (as done in section 3). The parameter estimates and standard deviations for each of the eight years are shown in Figures $11 \mathrm{a}$ and $11 \mathrm{~b}$.

Since 1990, Rio Grande do Norte and the Northeast show a slightly decreasing trend in the likelihood of a female household head experiencing. 
Figure 11a: Impact of gender for Rio Grande do Norte

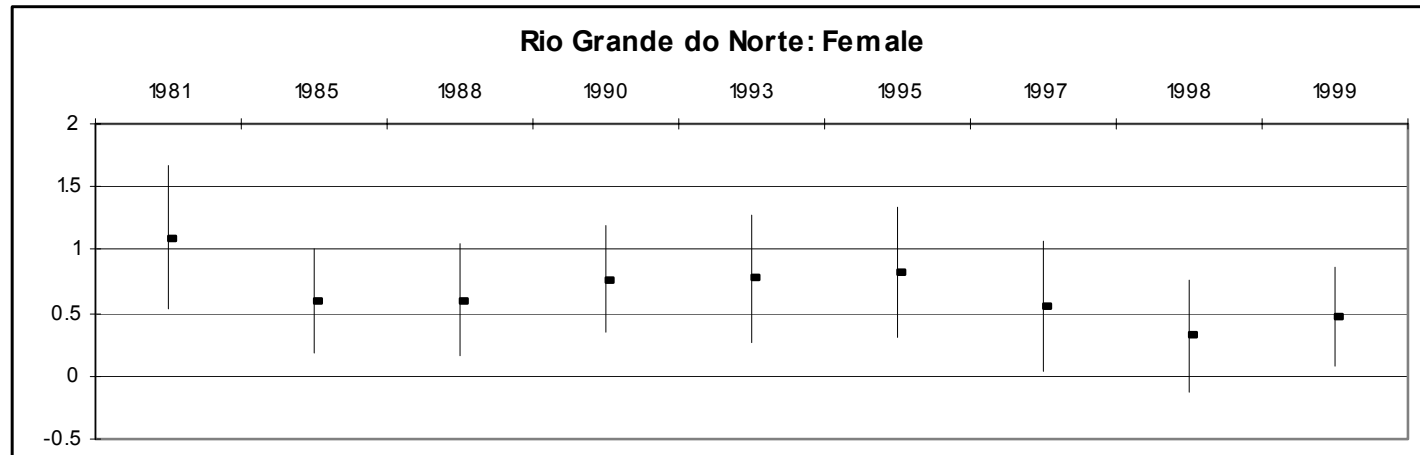

Source: Authors' calculations based on PNADs 1981 to 1999.

Note: Figures are probit coefficients and confidence intervals for female dummy.

\section{Figure 11b: Impact of gender for Northeast}

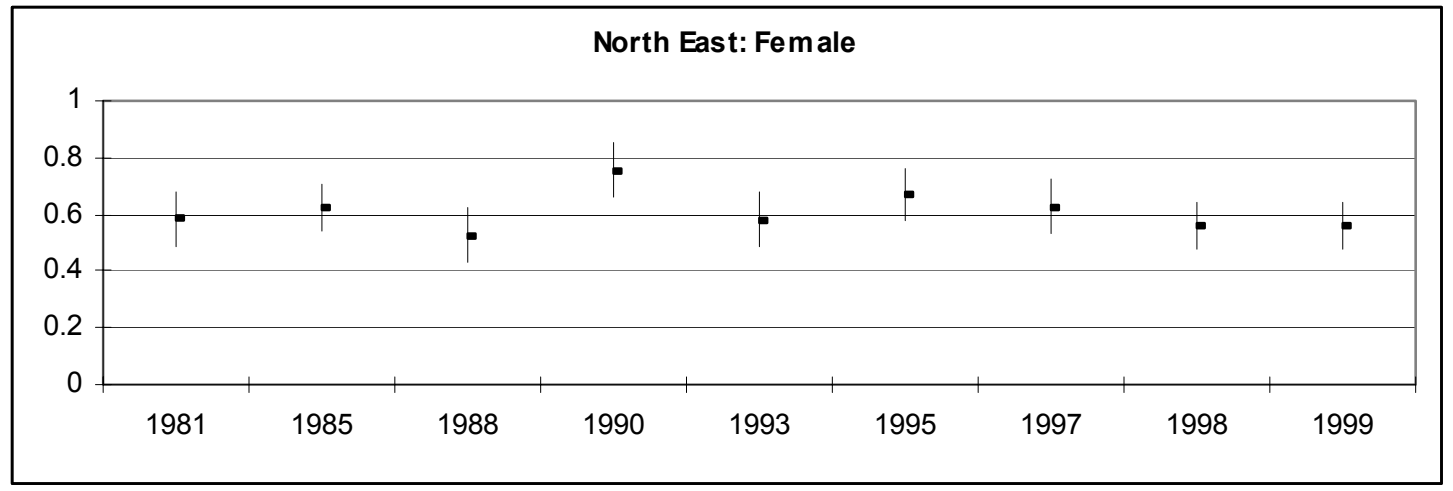

Source: Authors' calculations based on PNADs 1981 to 1999.

Note: Figures are probit coefficients and confidence intervals for female dummy.

\subsubsection{Experience and family characteristics}

In the labor market literature, skills and experience are often proxied by the age of a worker. When we include the age and age squared, the latter to capture nonlinearities in the data, both turn out statistically significant correlates of poverty for some years while for other years age is only marginally significant. This indicates that the older the household head the lower probability the household will be poor, albeit at a decreasing rate for the old age. These findings reveal that the household combination is more important than age of the household head, since other included family characteristics are strongly 
statistically significant in explaining the likelihood of experiencing poverty for all years and for both Rio Grande do Norte and the Northeast.

The household size is statistically significant and positively correlated with the incidence of poverty. Moreover, larger households are poorer and the effect is concave, indicating that the scaling factor matters for poverty (Figures 12a and 12b). This finding holds for both the Northeast region and for Rio Grande do Norte. However, the adverse impact of a large family on the likelihood of escaping poverty has increased in the 1990s for the region as a whole. In Rio Grande do Norte the impact seems to have been constant.

\section{Figure 12a: Impact of household size for Rio Grande do Norte}

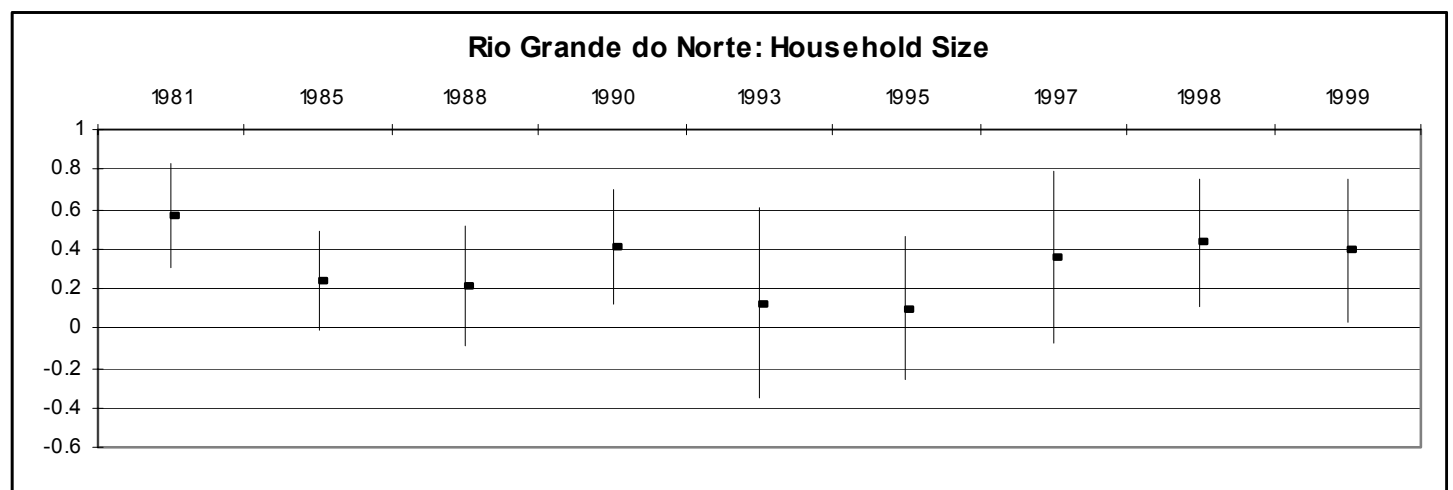

Source: Authors' calculations based on PNADs 1981 to 1999.

Note: Figures are probit coefficients and confidence intervals for household size.

\section{Figure 12b: Impact of household size for Northeast}

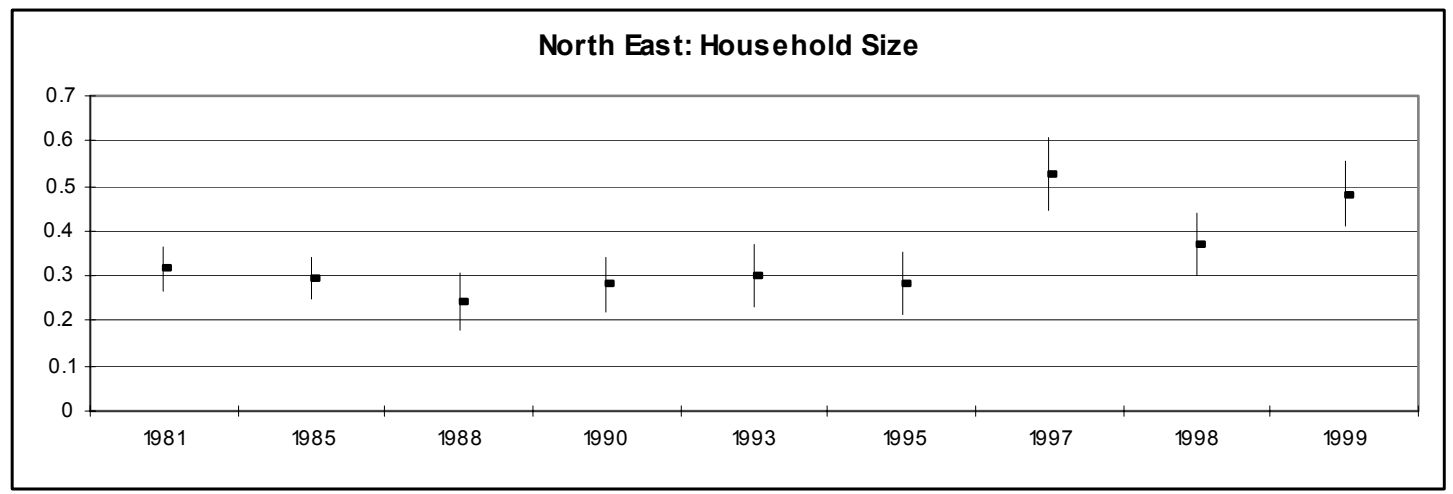

Source: Authors' calculations based on PNADs 1981 to 1999.

Note: Figures are probit coefficients and confidence intervals for household size. 
Figure 13a: Impact of having children below the age of 5 for Rio Grande do Norte

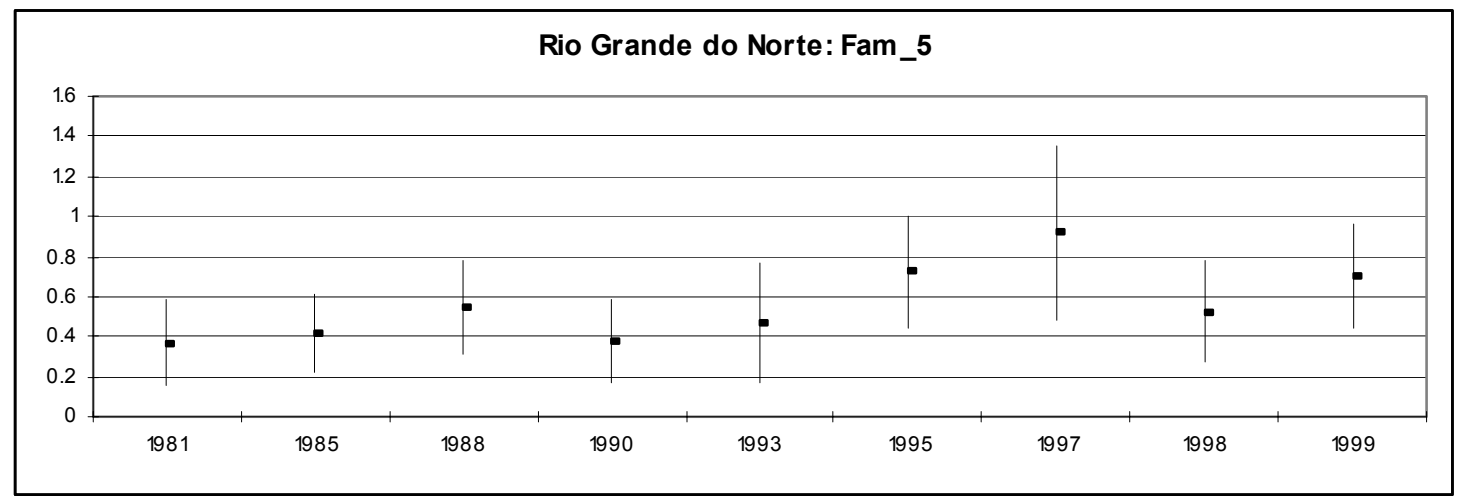

Source: Authors' calculations based on PNADs 1981 to 1999.

Note: Figures are probit coefficients and confidence intervals for fam_ 5 dummy.

Figure 13b: Impact of having children below the age of 5 for Northeast

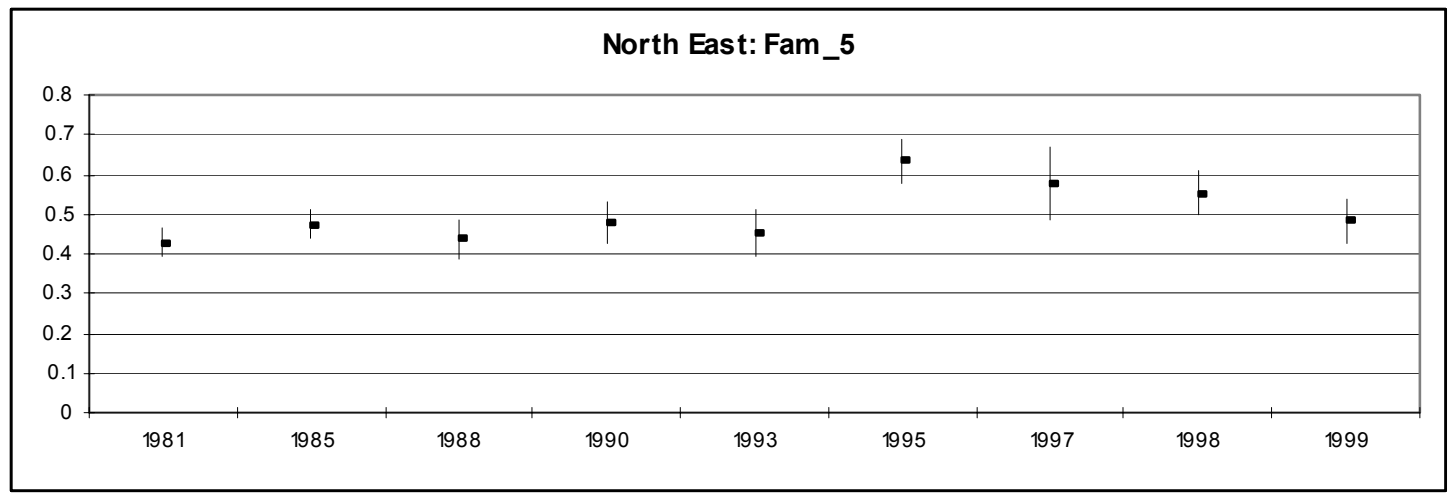

Source: Authors' calculations based on PNADs 1981 to 1999.

Note: Figures are probit coefficients and confidence intervals for fam_ 5 dummy.

In Rio Grande do Norte and the Northeast, families with members under the age of 5 appear more likely to be poor than families with no children below 5 (Figures 13a and 13b). This finding indicates that households with young children are more vulnerable than households with no children below the age of five. Furthermore, the probability of experiencing poverty for families with small children has been constant over the past decade. One direct policy intervention would be to facilitate access to childcare. In particular, the poor find the shortage of affordable childcare a large obstacle to their daily chores, see "Voices of the Poor" (1999). The gender finding paired with this small 
children finding indicates that single mothers with small children are far more likely to experience poverty than, for example, male-headed households with no children.

Figure 14a: Impact of having children between the age of 5 and 15 for Rio Grande do Norte

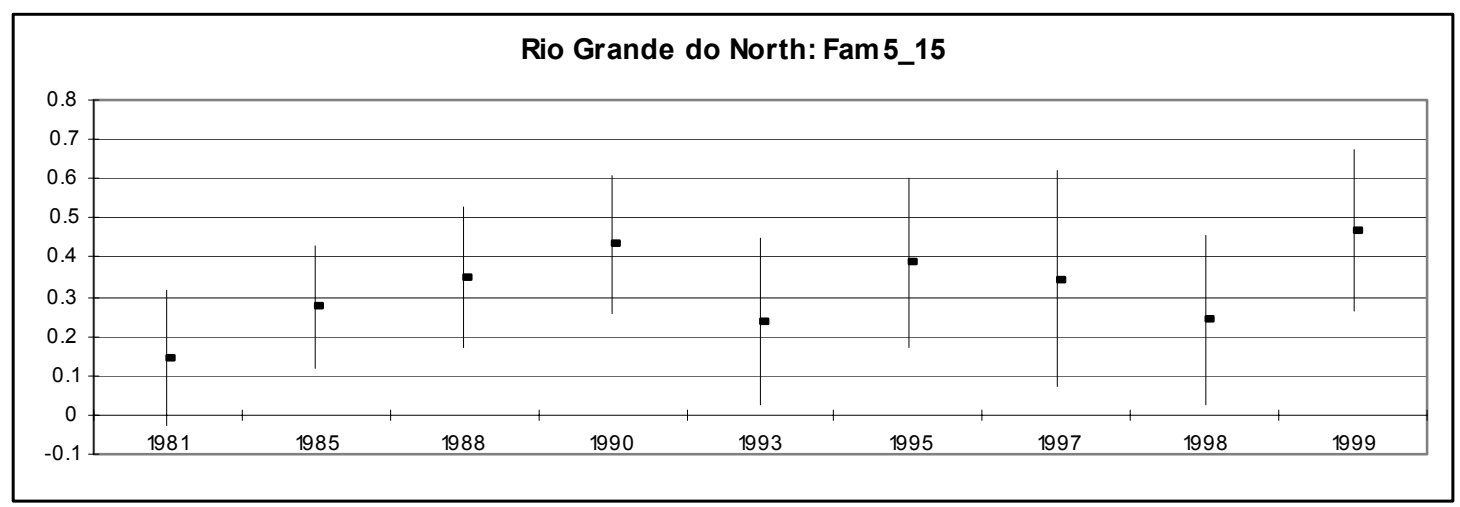

Source: Authors' calculations based on PNADs 1981 to 1999.

Note: Figures are probit coefficients and confidence intervals for fam5_15 dummy.

\section{Figure 14b: Impact of having children between the age of 5 and 15 for Northeast}

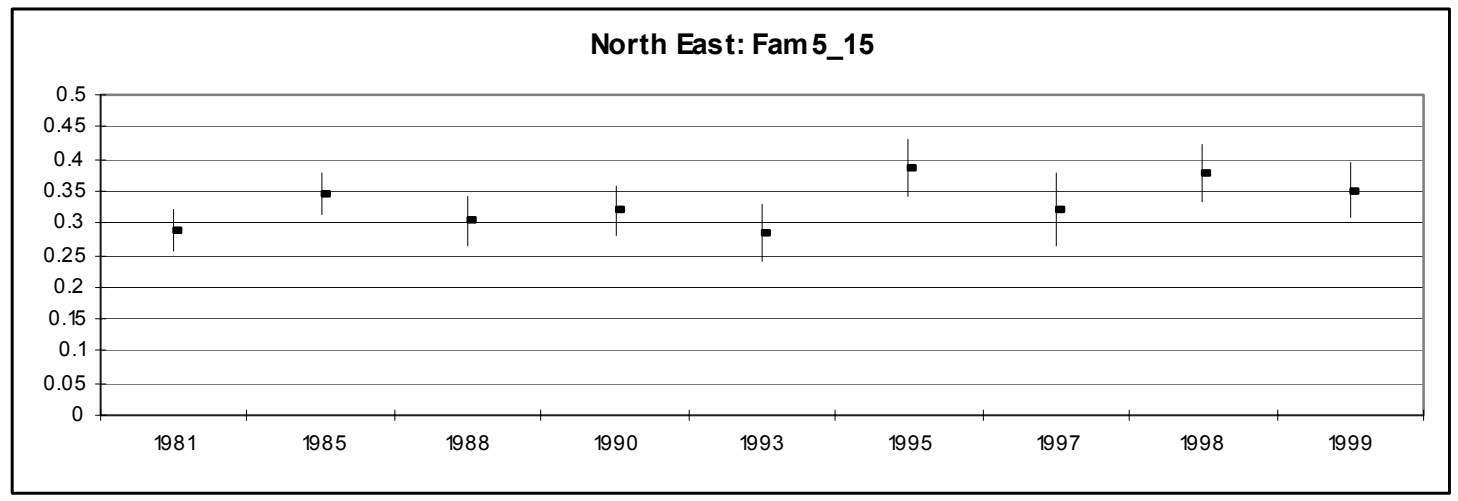

Source: Authors' calculations based on PNADs 1981 to 1999.

Note: Figures are probit coefficients and confidence intervals for fam5_15 dummy.

Also, households with members between the age of 5 and 15 have a large probability of being poor compared to the average, albeit their likelihood is lower than for families with small children. For Rio Grande do Norte and the Northeast, the impact seems rather constant across the 1980s and 1990s, but with a tendency to increase in recent years (Figures 14a and 14b). 
For Rio Grande do Norte and the Northeast, the presence of an elder household member (above 65 years of age) is significantly and negatively correlated with poverty. That is, having an old-aged in the household implies a lower chance of falling below the poverty line. This finding may at first seem surprising, but since elder people rarely retire completely in developing countries, it is not so unexpected. Furthermore, in Brazil many old-aged receive some form of a pension that contributes positively to the household income and, therefore, reduce the likelihood of experiencing poverty.

Figure 15a: Impact of having old-aged in the household for Rio Grande do Norte

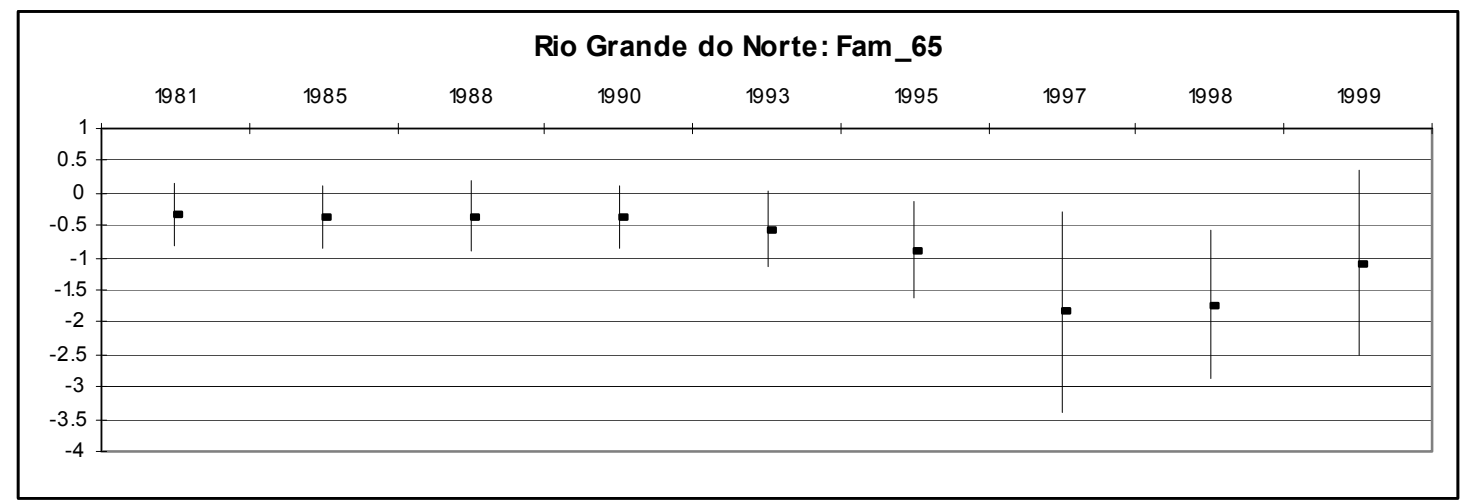

Source: Authors' calculations based on PNADs 1981 to 1999.

Note: Figures are probit coefficients and confidence intervals for fam65 dummy.

Figure 15b: Impact of having old-aged in the household for Northeast

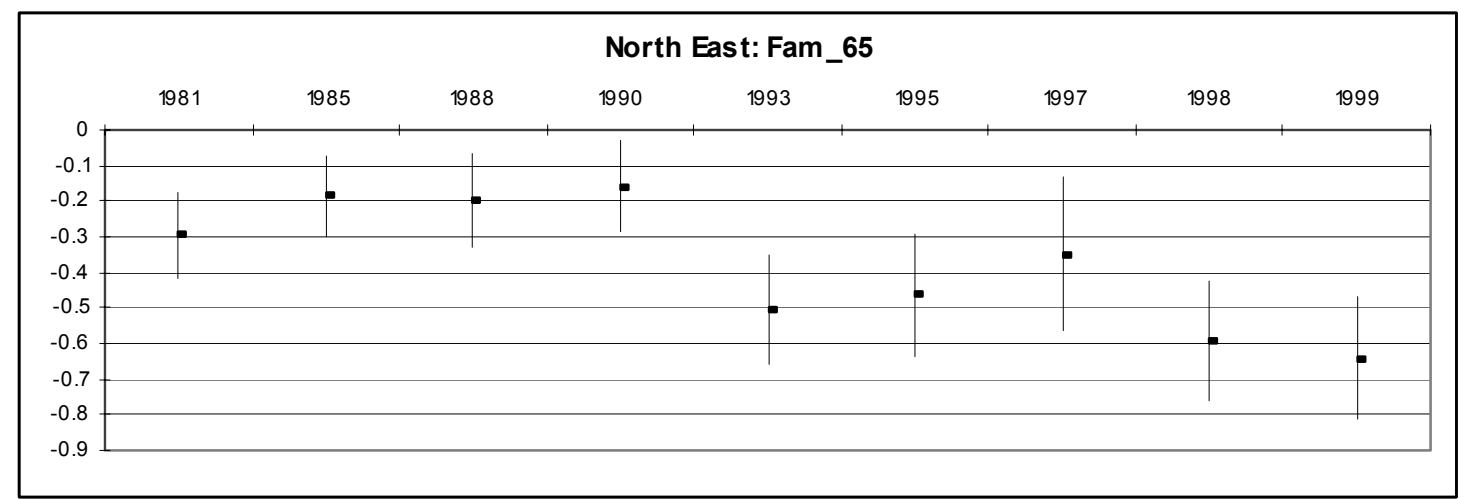

Source: Authors' calculations based on PNADs 1981 to 1999.

Note: Figures are probit coefficients and confidence intervals for fam65 dummy.

The coefficient estimate for the 1980s is rather constant (Figures 15a and 15b). In the Northeast, the impact has marginally decreased in the 1990s, indicating that in recent years households with old-aged members are even less likely to be poor than in the early 
1980's. This finding might be indicative of a positive impact of the recent pension reform on poverty, which brought a substantial increase in the coverage of social security in Brazil and had a substantial impact mainly on rural poverty. The 1988 Federal Constitution established the universal right to social security and instituted special eligibility conditions for rural workers under the Regime Geral da Previdência Social (RGPS), Brazil's public pension system for workers in the private sector. Recent analysis based on the 1996-1997 Pesquisa sobre Padrões de Vida (PPV) survey, found that the proportion of rural households receiving pensions from public institutions averages 30 percent in Brazil's poorer Northeast, and 24 percent in the Southeast. Also Delgado (1999) and Beltrao et. al. (1999) find that the implementation of the 1988 eligibility and benefit criteria has been effective in lowering the incidence of poverty among rural households. Furthermore, there has been a substantial increase in the coverage of social security in Brazil in the last decade, which had a substantial impact mainly on rural poverty, through the Lei Orgânica de Assistência Social ((LOAS), which became effective in 1993. The rural pension takes the form of a monthly payment of one minimum salary paid to claimants above 67 years of age or disabled and with per-capita household income less than one-quarter of a minimum salary. The findings from the probit analyses may indicate that the rural pension scheme has been well targeted.

\subsubsection{Ethnic Background}

For Rio Grande do Norte and the Northeast region, we find that ethnic background (white, black, mulatto) is an import factor contributing to poverty, controlling for other household head characteristics. Data on ethnic origin is only available since 1988. Mulattos and black Nordestinos have a higher incidence of poverty than their white peers. This is in line with what we had observed from the simple statistics presented previously. That indicates that on average black and mulatto-headed households are poorer than whites. The probit regression findings underline the importance of the ethnic background. There are measurable differences between whites and non-whites, controlling for other characteristics. Family and education variables capture part of the difference found in the simple unconditional mean incomes, but still a large part is due to discrimination or other unexplained individual characteristics of the non-white population group in the NE. 


\subsubsection{Urban versus rural living}

For the Northeast and also for Rio Grande do Norte, the urban versus rural living is a significant correlate to poverty in both the 1980s and 1990s, with rural households being more likely to experience poverty than urban ones. This is in line with what we observed earlier in the simple statistics. Hence it is a fact that the rural population is more poverty prone the population in urban areas.

\subsubsection{Formal employment and sector of employment}

We find that households where the household head works in the formal sector ("com carteira assinada") are statistically significantly less likely to be poor. This finding holds for both the 1980s and 1990s and all states in the Northeast region.

For Rio Grande do Norte, the sector-agriculture, services, industry and public of employment is an insignificant correlate of poverty. Hence, when the head of household is engaged in service and industrial sectors, the household is not necessarily poorer than their counterparts employed in the agricultural sector. This does not seem to be the case for the Northeast as a whole, where a household head working in agriculture is significantly poorer than household heads engaged in the service and industrial sectors. Also, for the Northeast at least during the 1980s, public sector employment was a central personal attribute of the household head determining the likelihood that a household experiences poverty. The public sector dummy variable is statistically significantly different from zero and negative for the 1980s and also negative but no longer significant in the 1990s. The coefficient estimates reveal that the public sector cushioned this group of workers at least during the 1980s. But in the 1990s they are not enumerated neither more or less than what their human capital calls for.

\subsubsection{Further remarks}

By no means is this analysis fully complete, as important information identified by the poor themselves in the Northeast is not directly included in the analysis, for example, safety, peace of mind, good health, sustainable environment, belonging to a community, 
and freedom of choice and action. In particular, crime, violence and safety are flagged as important problems and obstacles to well-being in the poor communities.

\section{Conclusion and Policy Recommendations}

In the Northeast region of Brazil, the poverty picture of the past two decades reveals large fluctuations in the headcount poverty index and squared poverty gap poverty measures. Hence, in the medium term, one fairly clear conclusion is that economic expansion can only do so much in alleviating poverty. Even during the upturns that created pro-poor economic growth, many people were still left in severe poverty. Therefore, poverty reduction can be achieved not only from economic expansion but targeted social policies including safety nets and redirection of current social expenditures are also needed. Targeted interventions can protect the elderly, children, households with small children, and other vulnerable groups in the Northeast. Covariant shocks, for example, economic recessions, may create a role for other programs, such as, workfare, as long as wages are low in order not to crowd out productive private activities.

Findings reveal that individual characteristics such as education, experience and labor market association of the household head are important correlates of poverty. Taking these into account they reveal that in 1999 a Nordestino is 24-percentage-points more likely to fall below the indigent poverty line than other Brazilians. Within the NE, only Piauí and Bahia are statistically different from the NE average. Household heads in Piauí are more likely to become poor than elsewhere in the NE region, while head of households from Bahia are less likely to be poor than the rest of the NE. Rio Grande do Norte and other states in the NE region are not more nor less likely to be poor. Data reveal that there are very large differences in poverty levels by education in the Northeast and all-Brazil. Moreover, these differences have increased over time, for example, since 1995, the headcount poverty index for people with some primary education appears to have increased, while the headcount index for people with some university education has fallen from its already very low level. There is a great deal of debate about the causes for these changes such as skill-biased technological change, changes in the relative supply of and demand for workers with different characteristics, and trade liberalization have all been mentioned as possible explanations (Blom and Velez 2001; Blom, Pavcnik and Schady 
2001). Lack of education is clearly the one and most important contributing factor to the likelihood of a household being poor for the Northeast and its states. Furthermore, we observe that the probability of being poor is decreasing with increasing education attainment. These findings hold for every state in the Northeast as well as Brazil as a whole. Two implications for the design of poverty alleviation policies are the following. First, it reinforces the need to ensure that more children from poor households stay in school longer, and receive high-quality education. This is particularly important in Brazil, where there is considerable evidence of very high rates of intergenerational transmission of human capital. Second, the results show that education levels are highly-and increasingly - correlated with poverty, and may therefore be a good proxy for any policy designed to target poor households ${ }^{27}$.

The gender of the household head alone does not matter for poverty according to the poverty profile, as around 40 percent of both male and female heads are poor. But, once when we control for education (women are more educated than men) and other individual characteristics, female-headed households have a much larger likelihood of being poor than male-headed households. As lack of education appears to be more important than gender in explaining poverty, transfer program which target transfers to households headed by people with low education would have a larger impact on poverty than a comparable program which targets female-headed households ${ }^{28}$.

The household size is positively correlated with the incidence of poverty. Larger households are poorer than smaller ones and the effect is concave. Furthermore, larger households are more likely to fall into poverty in the 1990s than in the 1980s. Moreover, households with members under the age of 5 appear are more likely to fall below the poverty line than families with no children below 5 years old. Also, households with members between the ages of 5 and 15 have a large probability of being poor, albeit the likelihood is lower than for families with small children. The numerical predominance of families with small children placed below the poverty line should serve as a reminder that they should not be neglected in the design of safety nets and other remedial policies. Our analysis suggests that interventions, which benefit very young children should receive the

\footnotetext{
27 Thanks to Norbert Schady for this comment.

${ }^{28}$ Thanks to Norbert Schady for this comment.
} 
highest priority in Northeast Brazil. These findings indicate that policies targeting this group would contribute to a reduction of poverty. One such initiative could be increased access to childcare and other social services.

The presence of old-aged people (above 65 years of age) in the household is an important factor contributing to poverty reduction in the Northeast and elsewhere in Brazil. The poverty rate for households with children under the age of six is four-and-a-half times the poverty rate of households with members aged 66 or older. Furthermore, we find that old-age poverty experienced a fall since the middle of the 1990s. Moreover, we find that there is no regional differences in the probability of falling below the poverty line for the elderly in Brazil.

The poverty profiles indicate that blacks and mulattos are significantly poorer than their white counterparts. This finding is confirmed by the probit regressions for the $1980 \mathrm{~s}$ and the beginning of the 1990s, even when controlling for other household head characteristics.

Informal sector workers are much more likely to experience poverty than formal sector worker. Current labor market programs such as unemployment insurance, training, and severance payments have little poverty impact as they are highly directed towards formal-sector employees. The informal-sector workers are therefore left out. The importance of extending the social safety nets to the informal-sector may create a positive welfare impact. One route to increase well-being of informal-sector workers is to supply programs that increase skill levels and hence productivity.

Providing better access (full property rights) to cheaper capital to informal producers could also help the progression of poverty, as productivity in the informal sector is often limited by credit constraints.

Finally, though poverty reduction over the last decades appeared to be mainly driven by federal policies, it appears that some states were more successful in reducing poverty than others. In particular, the relatively good performance of Maranhão, Piauí, Ceará, Paraíba, and Rio Grande do Norte that reduced the headcount poverty ratio by 9 or more percentage points in the 1981-99 period indicates scope for regional coordinated poverty reduction strategies. 


\section{References}

Atlas do Desenvolvimento Humano no Brasil (1998). IBGE.

Amadeo, E. and M. Neri, (1997). "Macroeconomic Policy and Poverty in Brazil." Texto para Discussão N 383, PUC-Rio, Rio de Janeiro, dezembro de 1997.

Barros, R., S. Firpo and R. Mendoça, (1999). "Education and Equitable Economic Development." IPEA.

Barros, R. and R. Mendoça, (1998). "O Impacto de três inovações instrucionais na Educação Brasileira” IPEA, Texto para Discussão No. 566.

Beltrão, Kaizô Iwakami, Sonoê Sugahara Pinheiro, Francisco Eduardo Barreto de Oliveira, (1999). “A População Rural e a Previdência Social no Brasil: Uma Análise Com Ênfase Nas Mudanças Constitucionais”, IPEA, mimeo

Carrizosa, M.; N. Fiess and D. Verner (2001). "“" Economic growth in Pernambuco and the Northeast Brazil". World Bank mimeo.

Consultations with the poor, (1999). Also called "Voices of the Poor." World Bank.

Deaton, A. (1997). “The Analysis of Household Surveys.” World Bank Book.

Delgado, Guilherme Costa, (1999). "Caso Brasil: Sistema de Previdência Social Rural, paper delivered at conference Experiências Exitosas de Combate à Pobreza Rural: Lições para Reorientação de Políticas”.

Dollar, D. and Kraay, A. (2000). "Growth IS good for the poor, International Monetary Fund Seminar Series.” World Bank, No. 2000-35:1-44. 
Elbers, C., J. Olson Lanjouw, P. Lanjouw and P. G. Leite (2001). "Poverty and Inequality in Brazil: Estimates from Combined PPV-PNAD Data.” World Bank mimeo.

Ferreira, F., P. Lanjouw and M. Neri (1999). "The Urban Poverty in Brazil: A New Poverty Profile Using PVV, PNAD and Census Data.” World Bank mimeo.

Fiess, N.. W. Maloney and R. Shankar (2000), “Informality, Wage Rigidities and Real Exchange Rates in Brazil, Colombia and Mexico, mimeo, The World Bank.

Foster, Greer, and Thorbecke (1984). "A class of decomposable poverty measures." Econometrica, 52, 761-65.

Neri, M., 1999. "Uma fotografia recente da pobreza brasileira.", PNAD data, 1981-98, IBGE.

Verner, D. (2000). "Wage determination in Pernambuco: An application of Quantile Regressions."

Wodon, Q. (2000): "Poverty and Policy in Latin America and the Caribbean, World Bank Technical Paper, No. 467.

WDR (2000). “World Development Report 2000”. 
Coding of the Variables from the PNAD dataset (1981-98)

Table A1: Variable Names

\begin{tabular}{|c|c|c|c|c|c|c|c|c|c|c|}
\hline \multirow[t]{2}{*}{ Category } & \multirow[t]{2}{*}{ Specification } & \multicolumn{8}{|c|}{ Series and Coding } & \multirow{2}{*}{$\begin{array}{l}\begin{array}{l}0-1 \text { dummies } \\
(1: \text { yes })\end{array} \\
\end{array}$} \\
\hline & & 1981 & 1985 & 1988 & 1990 & 1993 & 1995 & 1997 & 1998 & \\
\hline \multirow[t]{3}{*}{ Gender } & & v0303 & $\mathrm{v0303}$ & $\mathrm{v0303}$ & v0303 & v0302 & v0302 & v0302 & $\mathrm{v0302}$ & \\
\hline & male & 1 & 1 & 1 & 1 & 2 & 2 & 2 & 2 & male \\
\hline & female & 3 & 3 & 3 & 3 & 4 & 4 & 4 & 4 & female \\
\hline \multirow[t]{2}{*}{ Age } & & $\mathrm{v0805}$ & v0805 & $\mathrm{v0805}$ & $\mathrm{v0805}$ & $\mathrm{v03034}$ & $\mathrm{v03034}$ & $\mathrm{v8005}$ & $\mathrm{v8005}$ & \\
\hline & & & & & & & & & & \\
\hline \multirow[t]{7}{*}{ Race } & & & & v0304 & v0304 & v0404 & v0404 & v0404 & v0404 & \\
\hline & white & & & 2 & 2 & 2 & 2 & 2 & 2 & white \\
\hline & black & & & 4 & 4 & 4 & 4 & 4 & 4 & black \\
\hline & Asian & & & 6 & 6 & 6 & 6 & 6 & 6 & asian \\
\hline & mulatto & & & 8 & 8 & 8 & 8 & 8 & 8 & mulatto \\
\hline & indigenous & & & & & 0 & 0 & 0 & 0 & indigenous \\
\hline & ignored & & & 9 & 9 & 9 & 9 & 9 & 9 & \\
\hline \multirow{3}{*}{ Urban/Rural } & & v03 & v03 & v03 & $\mathrm{v03}$ & v4728 & $\mathrm{v} 4728$ & $\mathrm{v} 4728$ & $\mathrm{v} 4728$ & \\
\hline & urban & 1,3 & 1,3 & 1,3 & 1,3 & $1,2,3$ & $1,2,3$ & $1,2,3$ & $1,2,3$ & urban \\
\hline & rural & 5,7 & 5,7 & 5,7 & 5,7 & $4,5,6,7,8$ & $4,5,6,7,8$ & $4,5,6,7,8$ & $4,5,6,7,8$ & rural \\
\hline & & & & & & & & & & \\
\hline \multirow[t]{5}{*}{$\begin{array}{l}\text { Typ of Region } \\
\text { (Metropolitan) }\end{array}$} & & v05 & v05 & v05 & v05 & $\mathbf{v 4 7 2 7}$ & $\mathrm{v} 4727$ & $\mathbf{v 4 7 2 7}$ & $\mathbf{v 4 7 2 7}$ & \\
\hline & & & & & & & & & & \\
\hline & metropolitan & 1 & 1 & 1 & 1 & 1 & 1 & 1 & 1 & metropol \\
\hline & self-representative & 2 & 2 & 2 & 2 & 2 & 2 & 2 & 2 & selfrep \\
\hline & not self-representative & 3 & 3 & 3 & 3 & 3 & 3 & 3 & 3 & notselfrep \\
\hline \multirow[t]{5}{*}{ Read and Write? } & & v0311 & v0311 & v0311 & v0311 & v0601 & v0601 & v0601 & v0601 & \\
\hline & yes & 1 & 1 & 1 & 1 & 1 & 1 & 1 & 1 & read \\
\hline & no & 3 & 3 & 3 & 3 & 3 & 3 & 3 & 3 & \\
\hline & $\mathrm{NA}$ & 9 & 9 & 9 & 9 & 0,9 & 0,9 & 0,9 & 0,9 & \\
\hline & & & & & & & & & & \\
\hline
\end{tabular}




\begin{tabular}{|c|c|c|c|c|c|c|c|c|c|c|}
\hline \multirow[t]{2}{*}{ Category } & \multirow[t]{2}{*}{ Specification } & \multicolumn{8}{|c|}{ Series and Coding } & $\begin{array}{l}\text { 0-1 dummies } \\
\text { (1:yes) }\end{array}$ \\
\hline & & 1981 & 1985 & $\overline{1988}$ & 1990 & 1993 & 1995 & $\overline{1997}$ & 1998 & \\
\hline & & & & & & & & & & \\
\hline \multirow[t]{7}{*}{\begin{tabular}{|l|}
$\begin{array}{l}\text { Years of } \\
\text { schooling }\end{array}$ \\
\end{tabular}} & & v0318 & v0318 & v0318 & v0318 & v06073 & v06073 & $\mathrm{v4703}$ & $\mathrm{v} 4703$ & \\
\hline & no or less than 1 & 1 & 1 & 1 & 1 & 1 & 1 & 1 & 1 & schooll \\
\hline & 1 to 4 & $2,3,4,5$ & $2,3,4,5$ & $2,3,4,5$ & $2,3,4,5$ & $2,3,4,5$ & $2,3,4,5$ & $2,3,4,5$ & $2,3,4,5$ & (school2) primary I \\
\hline & 5 to 8 & $6,7,8,9$ & $6,7,8,9$ & $6,7,8,9$ & $6,7,8,9$ & $6,7,8,9$ & $6,7,8,9$ & $6,7,8,9$ & $6,7,8,9$ & (school3) primary II \\
\hline & 9 to 12 & 10 & 10 & 10 & 10 & $10,11,12$ & $10,11,12$ & $10,11,12$ & $10,11,12$ & (school4) secondary \\
\hline & $>12$ & 11 & 11 & 11 & 11 & $13,14,15,16$ & $13,14,15,16$ & $13,14,15,16$ & $13,14,15,16$ & (school5) tertiary \\
\hline & NA & 12,13 & 12,13 & 12,13 & 12,13 & 17 & 17 & 17 & 17 & school6 \\
\hline \multicolumn{11}{|l|}{$\begin{array}{l}\text { Housing } \\
\text { Characteristics }\end{array}$} \\
\hline Type of House & & $\mathrm{v0202}$ & $\mathrm{v0202}$ & v0202 & v0202 & $\mathrm{v0202}$ & v0202 & $\mathrm{v0202}$ & v0202 & \\
\hline \multirow[t]{3}{*}{ Walls } & & v0203 & v0203 & v0203 & v0203 & $\mathrm{v0203}$ & $\mathrm{v0203}$ & $\mathrm{v0203}$ & $\mathrm{v0203}$ & \\
\hline & durable & 0,2 & 0,2 & 0,2 & 0,2 & 1,2 & 1,2 & 1,2 & 1,2 & dur_w \\
\hline & not durable & $4,6,8$ & $4,6,8$ & $4,6,8$ & $4,6,8$ & $3,4,5,6$ & $3,4,5,6$ & $3,4,5,6$ & $3,4,5,6$ & \\
\hline \multirow[t]{3}{*}{ Roof } & & v0205 & v0205 & $\mathrm{v0205}$ & v0205 & v0204 & v0204 & v0204 & v0204 & \\
\hline & durable & $0,2,4,6$ & $0,2,4,6$ & $0,2,4,6$ & $0,2,4,6$ & $1,2,3,4$ & $1,2,3,4$ & $1,2,3,4$ & $1,2,3,4$ & dur_r \\
\hline & not durable & 7,8 & 7,8 & 7,8 & 7,8 & $5,6,7$ & $5,6,7$ & $5,6,7$ & $5,6,7$ & \\
\hline \multirow[t]{7}{*}{$\begin{array}{l}\text { Ownership of } \\
\text { House } \\
\end{array}$} & & v0212 & v0212 & v0212 & v0212 & v0207 & v0207 & v0207 & v0207 & \\
\hline & own, paid & 0 & 0 & 0 & 0 & 0 & 0 & 0 & 1 & house1 \\
\hline & own house still paying & 2 & 2 & 2 & 2 & 2 & 2 & 2 & 2 & house2 \\
\hline & rent & 4 & 4 & 4 & 4 & 4 & 4 & 4 & 3 & house 3 \\
\hline & ceded & 6 & 6 & 6 & 6 & 6 & 6 & 6 & 4,5 & house4 \\
\hline & other & 8 & 8 & 8 & 8 & 8 & 8 & 8 & 6 & house5 \\
\hline & NA & 9 & 9 & 9 & 9 & 9 & 9 & 9 & 9 & house6 \\
\hline \multirow[t]{4}{*}{ Radio } & & & & v0217 & $\mathrm{v0217}$ & v0225 & $\mathrm{v0225}$ & v0225 & v0225 & \\
\hline & yes & & & 2 & 1 & 1 & 1 & 1 & 1 & radio \\
\hline & no & & & 4 & 3 & 3 & 3 & 3 & 3 & \\
\hline & NA & & & 9 & 9 & 9 & 9 & 9 & 9 & \\
\hline
\end{tabular}




\begin{tabular}{|c|c|c|c|c|c|c|c|c|c|c|}
\hline \multirow[t]{3}{*}{ Category } & \multirow[t]{3}{*}{ Specification } & \multicolumn{8}{|c|}{ Series and Coding } & \multirow{2}{*}{$\begin{array}{l}\text { 0-1 dummies } \\
\text { (1:yes) }\end{array}$} \\
\hline & & & & & & & & & & \\
\hline & & 1981 & 1985 & 1988 & 1990 & 1993 & 1995 & 1997 & 1998 & \\
\hline \multirow[t]{4}{*}{ TV colour } & & & & v0218 & v0218 & v0226 & v0226 & $\mathrm{v0226}$ & v0226 & \\
\hline & yes & & & 1 & 1 & & & & 1 & \multirow{2}{*}{$\begin{array}{l}\text { tv } \\
\text { (if v0226 or v0227 } \\
=1 \text { ) }\end{array}$} \\
\hline & no & & & 3 & 3 & & & & 3 & \\
\hline & NA & & & 9 & 9 & & & & 9 & \\
\hline \multirow[t]{4}{*}{ TV b\&w } & & & & & & v0227 & v0227 & v0227 & v0227 & \\
\hline & yes & & & 1 & 1 & & & & 1 & \\
\hline & no & & & 3 & 3 & & & & 3 & \\
\hline & NA & & & 9 & 9 & & & & 9 & \\
\hline \multirow[t]{4}{*}{ Cooker } & & v0215 & $\mathrm{v0215}$ & v0215 & v0215 & $\mathrm{v0221/ \textrm {v } 0 2 2 2}$ & $\mathrm{v0221/ \textrm {v } 0 2 2 2}$ & $\mathrm{v0221/ \textrm {v } 0 2 2 2}$ & $\mathbf{v 0 2 2 1 / v 0 2 2 2}$ & \\
\hline & yes & 2 & 2 & 2 & 2 & $1 \& 2$ & $1 \& 2$ & $1 \& 2$ & $1 \& 2$ & \multirow{2}{*}{$\begin{array}{l}\text { cooker } \\
\text { (if v0221 =1 or } \\
\text { v0222=2) }\end{array}$} \\
\hline & no & 4 & 4 & 4 & 4 & $3 \& 4$ & $3 \& 4$ & $3 \& 4$ & $3 \& 4$ & \\
\hline & NA & 9 & 9 & 9 & 9 & 9 & 9 & 9 & 9 & \\
\hline \multirow[t]{4}{*}{ Fridge } & & v0216 & v0216 & $\mathrm{v0216}$ & v0216 & v0228 & v0228 & v0228 & $\mathrm{v0228}$ & \\
\hline & yes & 1 & 1 & 1 & 1 & 1 & 1 & 1 & 1 & Fridge \\
\hline & no & 3 & 3 & 3 & 3 & 3 & 3 & 3 & 3 & \\
\hline & NA & 9 & 9 & 9 & 9 & 9 & 9 & 9 & 9 & \\
\hline Freezer & & & & & & v0229 & v0229 & v0229 & v0229 & Freezer \\
\hline $\begin{array}{l}\text { Washing } \\
\text { Machine }\end{array}$ & & & & & & v0230 & v0230 & v0230 & v0230 & Washer \\
\hline \multirow[t]{5}{*}{ Electricity? } & & v0210 & $\mathrm{v0210}$ & v0210 & v0210 & v0219 & v0219 & v0219 & v0219 & \\
\hline & Yes & 1 & 1 & 1 & 1 & 1 & 1 & 1 & 1 & Elec \\
\hline & No & 3 & 3 & 3 & 3 & & & & & \\
\hline & Other & & & & & 3,5 & 3,5 & 3,5 & 3,5 & \\
\hline & NA & 9 & 9 & 9 & 9 & 9 & 9 & 9 & 9 & \\
\hline \multirow[t]{4}{*}{ Water } & & v0206 & v0206 & v0206 & v0206 & v0212 & v0212 & v0212 & v0212 & \\
\hline & Piped & 1,4 & 1,4 & 1,4 & 1,4 & 2 & 2 & 2 & 2 & Water1 \\
\hline & Not piped & 2,5 & 2,5 & 2,5 & 2,5 & 4 & 4 & 4 & 4 & Water2 \\
\hline & Other/NA & $3,6,9$ & $3,6,9$ & $3,6,9$ & $3,6,9$ & 6,9 & 6,9 & 6,9 & 6,9 & Water3 \\
\hline
\end{tabular}




\begin{tabular}{|c|c|c|c|c|c|c|c|c|c|c|}
\hline \multirow[t]{2}{*}{ Category } & \multirow[t]{2}{*}{ Specification } & \multicolumn{8}{|c|}{ Series and Coding } & $\begin{array}{l}\text { 0-1 dummies } \\
\text { (1:yes) }\end{array}$ \\
\hline & & 1981 & 1985 & 1988 & 1990 & 1993 & 1995 & 1997 & 1998 & \\
\hline \multirow[t]{9}{*}{ Sanitation } & & v0207 & v0207 & v0207 & $\mathbf{v 0 2 0 7}$ & v0217 & v0217 & v0217 & v0217 & \\
\hline & $\begin{array}{l}\text { Sewerage system and } \\
\text { septic tank } 1\end{array}$ & 0 & 0 & 0 & 0 & 1,2 & 1,2 & 1,2 & 1,2 & San1 \\
\hline & Septic tank 2 & 2 & 2 & 2 & 2 & 3 & 3 & 3 & 3 & $\operatorname{san} 2$ \\
\hline & Rudimental cesspit & 4 & 4 & 4 & 4 & 4 & 4 & 4 & 4 & san3 \\
\hline & Drain & & & & & 5 & 5 & 5 & 5 & san4 \\
\hline & River or lake & & & & & 6 & 6 & 6 & 6 & san5 \\
\hline & Other & 6 & 6 & 6 & 6 & 7 & 7 & 7 & 7 & san6 \\
\hline & None & 8 & 8 & 8 & 8 & & & & & $\operatorname{san} 7$ \\
\hline & Not specified & 9 & 9 & 9 & 9 & 9 & 9 & 9 & 9 & $\operatorname{san} 7$ \\
\hline \multirow[t]{7}{*}{ Waste Disposal } & & v0209 & v0209 & v0209 & v0209 & v0218 & v0218 & v0218 & v0218 & \\
\hline & $\begin{array}{l}\text { Collected } \\
\text { directly/indirectly }\end{array}$ & 0 & 0 & 0 & 0 & 1,2 & 1,2 & 1,2 & 1,2 & waste1 \\
\hline & Burnt & 2 & 2 & 2 & 2 & 3 & 3 & 3 & 3 & waste2 \\
\hline & Burried & 4 & 4 & 4 & 4 & & & & & waste2 \\
\hline & $\begin{array}{l}\text { Dumped on unused land, } \\
\text { river, sea }\end{array}$ & 6 & 6 & 6 & 6 & 4,5 & 4,5 & 4,5 & 4,5 & waste3 \\
\hline & Other & 8 & 8 & 8 & 8 & 7 & 7 & 7 & 7 & waste4 \\
\hline & NA & 9 & 9 & 9 & 9 & 9 & 9 & 9 & 9 & waste5 \\
\hline \multirow[t]{11}{*}{$\begin{array}{l}\text { Worked in } \\
\text { reference week? }\end{array}$} & & v0501 & v0501 & $\mathrm{v0501}$ & v0501 & v09001 & v09001 & v9001 & v9001 & \\
\hline & Worked (trabalhou) & 1 & 1 & 1 & 1 & 1 & 1 & 1 & 1 & worked \\
\hline & Had work (tinha trabalho) & 2 & 2 & 2 & 2 & & & & & \\
\hline & Looking for work & 3 & 3 & 3 & 3 & & & & & \\
\hline & student & 4 & 4 & 4 & 4 & & & & & \\
\hline & $\begin{array}{l}\text { domestic worker (afazeres } \\
\text { dom.) }\end{array}$ & 5 & 5 & 5 & 5 & & & & & \\
\hline & retired & 6 & 6 & 6 & 6 & & & & & \\
\hline & other & 7 & 7 & 7 & 7 & & & & & \\
\hline & no & & & & & 3 & 3 & 3 & 3 & \\
\hline & NA & 9 & 9 & 9 & 9 & 0 & 0 & 0 & 0 & \\
\hline & & & & & & & & & & \\
\hline
\end{tabular}




\begin{tabular}{|c|c|c|c|c|c|c|c|c|c|c|}
\hline \multirow[t]{2}{*}{ Category } & \multirow[t]{2}{*}{ Specification } & \multicolumn{8}{|c|}{ Series and Coding } & $\begin{array}{l}\text { 0-1 dummies } \\
(1: y e s)\end{array}$ \\
\hline & & 1981 & 1985 & 1988 & 1990 & 1993 & 1995 & 1997 & 1998 & \\
\hline & & & & & & & & & & \\
\hline \multirow[t]{4}{*}{$\begin{array}{l}\begin{array}{l}\text { Economically } \\
\text { Active }\end{array} \\
\end{array}$} & & & v5011 & v5011 & v5011 & v090011 & v090011 & $\mathrm{v} 4704$ & $\mathrm{v4704}$ & \\
\hline & yes & & 1 & 1 & 1 & 1 & 1 & 1 & 1 & active \\
\hline & no & & 2 & 2 & 2 & 2 & 2 & 2 & 2 & \\
\hline & $\mathrm{NA}$ & & 3 & 3 & 3 & 3 & 3 & 3 & 3 & \\
\hline \multirow[t]{7}{*}{ Sector } & & v5040 & v5040 & v5040 & v5040 & v090072 & v090072 & $\mathrm{v} 4709$ & $\mathrm{v} 4709$ & \\
\hline & Agriculture & 1 & 1 & 1 & 1 & 1 & 1 & 1 & 1 & agri \\
\hline & Industry & $2,3,4$ & $2,3,4$ & $2,3,4$ & $2,3,4$ & $2,3,4$ & $2,3,4$ & $2,3,4$ & $2,3,4$ & industry \\
\hline & Services & $5,6,7,8$ & $5,6,7,8$ & $5,6,7,8$ & $5,6,7,8$ & $5,6,7,8$ & $5,6,7,8$ & $5,6,7,8$ & $5,6,7,8$ & service \\
\hline & Social & 9 & 9 & 9 & 9 & 9 & 9 & 9 & 9 & social \\
\hline & Public & 10 & 10 & 10 & 10 & 10 & 10 & 10 & 10 & public \\
\hline & other & 11 & 11 & 11 & 11 & 11 & 11 & 11 & 11 & \\
\hline \multirow[t]{10}{*}{ Work Position } & & v5050 & $\mathbf{v 5 0 5 0}$ & $\mathbf{v 5 0 5 0}$ & $\mathbf{v 5 0 5 0}$ & v090061 & v090061 & $\mathrm{v} 4706$ & $\mathrm{v} 4706$ & \\
\hline & Employee & 1 & 1 & 1 & 1 & $1,4,5$ & $1,4,5$ & $1,4,5$ & $1,4,5$ & employee \\
\hline & Domestic Worker & & & & & $6,7,8$ & $6,7,8$ & $6,7,8$ & $6,7,8$ & employee \\
\hline & Militar & & & & & 2 & 2 & 2 & 2 & \\
\hline & Public Servant & & & & & 3 & 3 & 3 & 3 & \\
\hline & Employer & 3 & 3 & 3 & 3 & 10 & 10 & 10 & 10 & employer \\
\hline & Self-employed & 2 & 2 & 2 & 2 & 9 & 9 & 9 & 9 & self \\
\hline & Self-sufficient worker & & & & & 11,12 & 11,12 & 11,12 & 11,12 & \\
\hline & unpaid & 4 & 4 & 4 & 4 & 13 & 13 & 13 & 13 & unpaid \\
\hline & other/NA & 5 & 5 & 5 & 5 & 14 & 14 & 14 & 14 & \\
\hline
\end{tabular}




\begin{tabular}{|c|c|c|c|c|c|c|c|c|c|c|}
\hline \multirow[t]{2}{*}{ Category } & \multirow[t]{2}{*}{ Specification } & \multicolumn{8}{|c|}{ Series and Coding } & \multirow{2}{*}{$\begin{array}{l}0-1 \text { dummies } \\
\text { (1:yes) }\end{array}$} \\
\hline & & 1981 & 1985 & 1988 & 1990 & 1993 & 1995 & 1997 & 1998 & \\
\hline \multirow[t]{5}{*}{$\begin{array}{l}\text { Assigned } \\
\text { workbook } \\
\text { (Carteira) } \\
\end{array}$} & & v0506 & v0506 & v0506 & v0506 & v09042 & v09042 & v9042 & v9042 & \\
\hline & & & & & & & & & & \\
\hline & yes & 2 & 2 & 2 & 2 & 2 & 2 & 2 & 2 & cart \\
\hline & no & 4 & 4 & 4 & 4 & 4 & 4 & 4 & 4 & \\
\hline & NA & 9 & 9 & 9 & 9 & 9 & 9 & 9 & 9 & \\
\hline \multicolumn{11}{|l|}{ Tenure } \\
\hline & Less than 1 year & & & & v3011 & $\mathrm{v090612}$ & v090612 & v9612 & v9612 & ten 0 \\
\hline & More than 1 year & & & & v3001 & $\mathrm{v090611}$ & v090611 & v9611 & v9611 & ten 1 \\
\hline & 1 to 3 years & & & & v3001 & v090611 & v090611 & v9611 & v9611 & ten 13 \\
\hline & 3 to 5 years & & & & v3001 & v090611 & v090611 & v9611 & v9611 & ten3 5 \\
\hline & more than 5 years & & & & v3001 & v090611 & v090611 & v9611 & v9611 & ten_5 \\
\hline & & & & & & & & & & \\
\hline \multicolumn{11}{|l|}{ Income Variables } \\
\hline $\begin{array}{l}\text { Valor de todas as } \\
\text { fontes }\end{array}$ & & v0601 & v0601 & v0601 & v0601 & v0905313 & v0905313 & v4720 & $\mathrm{v} 4720$ & \\
\hline $\begin{array}{l}\text { Valor do } \\
\text { rendimento } \\
\text { mensal domicilar }\end{array}$ & & & & & & $\mathrm{v0905314}$ & v0905314 & v4721 & $\mathrm{v} 4721$ & \\
\hline $\begin{array}{l}\text { Valor do } \\
\text { rendimento } \\
\text { mensal familiar }\end{array}$ & & v5010 & v5010 & v5010 & v5010 & v0905316 & v0905316 & v4726 & $\mathrm{v} 4726$ & \\
\hline
\end{tabular}




\section{A2: Spatial and temporal deflation of PNAD data sets}

Ferreira, Lanjouw and Neri (1999) specify a procedure to calculate spatial deflators for Brazil. Their regional price indices are based on the consumption patterns and implicit prices from the Pesquisa sobre Padrões de Vida (PPV) 1996/7 surveys. Since the PPV covers only the Northeast and the Southeast, Ferreira, Lanjouw and Neri (1999) obtain spatial price deflators for the rest of Brazil by means of extrapolation. The spatial price deflators are as follows:

\begin{tabular}{|l|c|}
\hline \multicolumn{2}{|l|}{ A Brazilian Spatial Price Index ( RM Sao Paulo $=1.0)$} \\
\hline PNAD Region & Spatial Price Deflator \\
\hline RM Fortaleza & 1.014087 \\
\hline RM Recife & 1.072469 \\
\hline RM Salvador & 1.179934 \\
\hline Northeast ( other urban areas) & 1.032056 \\
\hline Northeast (rural) & 0.953879 \\
\hline RM Belo Horizonte & 0.958839 \\
\hline RM Rio de Janerio & 1.002163 \\
\hline RM São Paulo & 1.000000 \\
\hline Southeast (other urban areas) & 0.904720 \\
\hline Southeast ( rural) & 0.889700 \\
\hline RM Porto alegre & 0.987001 \\
\hline RM Curitiba & 0.987001 \\
\hline South ( other urban areas) & 0.904720 \\
\hline South ( rural) & 0.889700 \\
\hline RM Belém & 1.088830 \\
\hline North ( other rural areas) & 1.037915 \\
\hline RM Brasília & 1.037915 \\
\hline Center West ( other urban areas) & 0.968388 \\
\hline
\end{tabular}

We assume that the structure of average regional cost-of-living described above remained constant over the period. This assumption is largely due to the lack of earlier comparable regional price information and in line with other research in this field (see Ferreira and Paes de Barros (1999)).

To deflated the different PNAD incomes over time, we use the monthly Brazilian consumer price indices, IPCA. In order to center the indices on the first day of the month, which is the reference date for PNAD incomes, we follow Ferreira and Paes de Barros 
(1999) and calculate the geometric average of the index for a month and for the preceding month as that month's deflator. After adjusting for the five currency conversion from the Cruzado to the Real, the final values to convert current incomes into 1997 Reais were as follows: ${ }^{1}$

\begin{tabular}{|c|c|}
\hline \multicolumn{2}{|l|}{ Brazilian Temporal Price Deflators $(\mathbf{1 9 9 7}=\mathbf{1 . 0})$} \\
\hline Year & Temporal Deflator \\
\hline 1981 & 47.766 \\
\hline 1983 & 2192.602 \\
\hline 1985 & 129.913 \\
\hline 1988 & 63.626 \\
\hline 1990 & 67.570 \\
\hline 1993 & 0.833 \\
\hline 1995 & 0.947 \\
\hline 1997 & 1.000 \\
\hline 1998 & 1.024 \\
\hline 1999 & 1.084 \\
\hline
\end{tabular}

\begin{tabular}{l}
\hline \multicolumn{1}{l|}{} \\
\begin{tabular}{|l|l|l|}
\hline Currency Conversion Dates and Rates: \\
\hline 28 February 1986 & 1 Cruzado & 1000 Cruzeiros \\
\hline 15 January 1989 & 1 Novo Cruzado & 1000 Cruzados \\
\hline 16 March 1990 & 1 Cruzeiro & 1 Novo Cruzado \\
\hline 1 August1993 & 1 Cruzeiro Real & 1000 Cruzeiros \\
\hline 1 July1994 & 1 Real & 2750 Cruzeiros Reais \\
\hline
\end{tabular}
\end{tabular}




\section{A3: A note on price deflation prior to $1990 \mathrm{~s}$}

In a hyper inflationary environment such as in Brazil prior to 1994, anyone interested in evaluating poverty dynamics in Brazil faces the difficulty of selecting an appropriate deflator. It is therefore not surprising, that different studies come up with very different results. By and large studies on the development in Brazil seems to agree that the Real Plan of 1994 had a substantial effect on reducing poverty in Brazil, while since 1995 no significant progress in poverty reduction has been made. (Figure 1).

Figure 1 produces a poverty profile based on the headcount index and the methodology described in the paper. The three poverty profiles only differ by the underlying time deflators. $P 0 \_$Def2 is based on the historic series of INPC, P0_Def1 also uses the historic series of INPC, however calculates the PNAD deflators as the geometric average of the month and the previous month, P0_Def3 uses deflators derived from the real minimum wage series from IBGE - which are also INPC based, but subject to IBGE modifications.

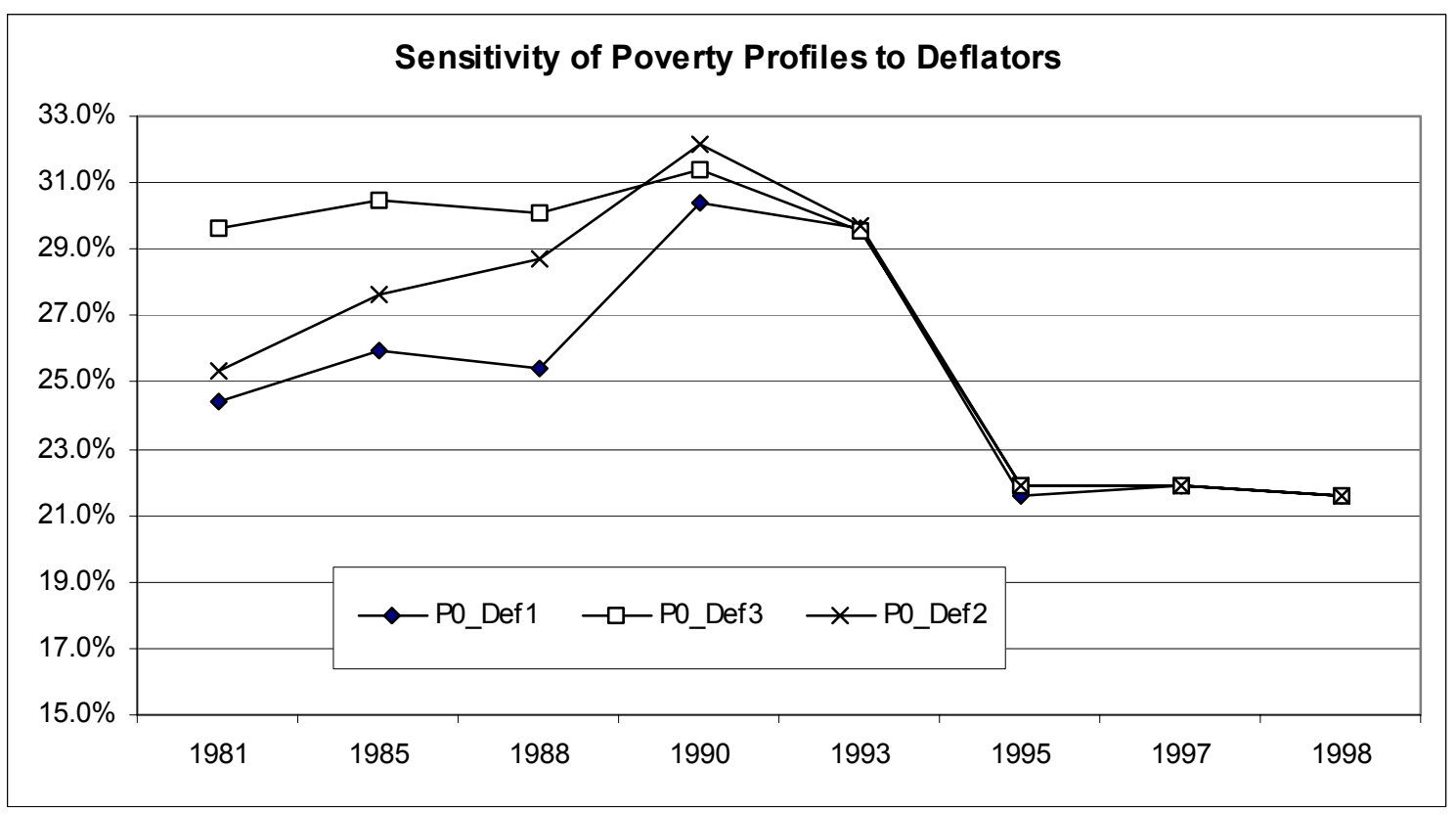

Even though the time deflators are very similar, the different dynamics in poverty are quite astonishing:

\begin{tabular}{llll}
\hline & Def1 & Def2 & Def3 \\
\hline 1981 & 48.989 & 47.750 & 56.514 \\
1985 & 2308.064 & 2192.602 & 2517.196 \\
1988 & 145.592 & 129.913 & 151.435 \\
1990 & 67.902 & 63.626 & 65.548 \\
1993 & 77.813 & 77.813 & 77.350 \\
1995 & 0.849 & 0.833 & 0.848 \\
1997 & 1.000 & 1.000 & 1.000 \\
1998 & 1.023 & 1.024 & 1.032 \\
1998 & 1.023 & 1.024 & 1.032 \\
\hline
\end{tabular}




\section{DHB Tables}

Table B1: per capita household income and inequality - DHB tables

\begin{tabular}{l|l|l|l|l|l|l|l}
\hline \multirow{2}{*}{} & & \multicolumn{3}{|c|}{$\begin{array}{c}\text { PER CAPITA MÉDIA } \\
\text { (Sal. Min. de set / 91) }\end{array}$} & \multicolumn{3}{c}{ (THEIL - L) } \\
\cline { 3 - 8 } & & 1970 & 1980 & 1991 & 1970 & 1980 & 1991 \\
\hline & & & & & & & \\
\hline Centro-Oeste & CO & 0.54 & 1.45 & 1.45 & 0.55 & 0.66 & 0.70 \\
\hline Nordeste & NE & 0.31 & 0.69 & 0.65 & 0.57 & 0.65 & 0.78 \\
\hline Norte & NO & 0.41 & 0.92 & 0.89 & 0.44 & 0.56 & 0.72 \\
\hline Sudeste & SE & 0.93 & 1.98 & 1.77 & 0.61 & 0.60 & 0.66 \\
\hline Sul & SU & 0.58 & 1.47 & 1.38 & 0.53 & 0.58 & 0.63 \\
\hline Brasil & BR & $\mathbf{0 . 6 3}$ & $\mathbf{1 . 4 3}$ & $\mathbf{1 . 3 1}$ & $\mathbf{0 . 6 8}$ & $\mathbf{0 . 7 0}$ & $\mathbf{0 . 7 8}$ \\
\hline
\end{tabular}

Table B2:Poverty Measures and Inequality based on DHB tables

\begin{tabular}{|c|c|c|c|c|c|c|c|c|c|c|}
\hline & \multicolumn{3}{|c|}{$\begin{array}{l}\text { PORCENTAGEM DE } \\
\text { PESSOAS COM RENDA } \\
\text { INSUFICIENTE (PO ) }\end{array}$} & \multicolumn{3}{|c|}{$\begin{array}{c}\text { INSUFICIÊNCIA } \\
\text { MÉDIA DE } \\
\text { RENDA (P1) }\end{array}$} & \multicolumn{3}{|c|}{$\begin{array}{c}\text { GRAU DE } \\
\text { DESIGUALDADE } \\
\text { NA POPULAÇÃO COM } \\
\text { RENDA INSUFICIENTE } \\
\text { (P2) }\end{array}$} \\
\hline & & 1970 & 1980 & 1991 & 1970 & 1980 & 1991 & 1970 & 1980 & 1991 \\
\hline Centro-Oeste & $\mathrm{CO}$ & 73.71 & 37.48 & 39.31 & 0.40 & 0.15 & 0.17 & 0.26 & 0.09 & 0.10 \\
\hline Nordeste & NE & 87.85 & 66.53 & 71.68 & 0.58 & 0.35 & 0.42 & 0.43 & 0.23 & 0.29 \\
\hline Norte & NO & 80.10 & 51.29 & 58.63 & 0.45 & 0.23 & 0.31 & 0.29 & 0.14 & 0.21 \\
\hline Sudeste & SE & 50.60 & 22.65 & 29.66 & 0.26 & 0.09 & 0.13 & 0.17 & 0.05 & 0.08 \\
\hline Sul & SU & 69.89 & 31.92 & 36.88 & 0.37 & 0.13 & 0.17 & 0.23 & 0.07 & 0.10 \\
\hline Brasil & BR & 67.90 & 39.47 & 45.46 & 0.39 & 0.18 & 0.24 & 0.27 & 0.11 & 0.16 \\
\hline
\end{tabular}


Table B3: per capita household income and inequality - DHB tables

\begin{tabular}{l|r|r|r|r|r|r}
\hline \multirow{2}{*}{\multicolumn{1}{c|}{ ESTADO }} & \multicolumn{3}{|c|}{$\begin{array}{c}\text { RENDA FAMILIAR } \\
\text { PER CAPITA MÉDIA } \\
\text { (Sal. Min. de set / 91) }\end{array}$} & \multicolumn{3}{c}{$\begin{array}{r}\text { GRAU DE DESIGUALDADE } \\
\text { (THEIL - L) }\end{array}$} \\
\cline { 2 - 8 } & 1970 & 1980 & 1991 & 1970 & 1980 & 1991 \\
\hline Alagoas & 0.30 & 0.62 & 0.62 & 0.52 & 0.58 & 0.71 \\
\hline Bahia & 0.36 & 0.84 & 0.68 & 0.58 & 0.65 & 0.80 \\
\hline Ceará & 0.26 & 0.64 & 0.65 & 0.60 & 0.69 & 0.81 \\
\hline Maranhão & 0.27 & 0.49 & 0.46 & 0.33 & 0.51 & 0.64 \\
\hline Paraíba & 0.23 & 0.56 & 0.59 & 0.58 & 0.65 & 0.73 \\
\hline Pernambuco & 0.38 & 0.83 & 0.81 & 0.63 & 0.65 & 0.80 \\
\hline Piauín & 0.19 & 0.43 & 0.50 & 0.46 & 0.61 & 0.76 \\
\hline Rio Grande do & $\mathbf{0 . 2 6}$ & $\mathbf{0 . 6 8}$ & $\mathbf{0 . 7 2}$ & $\mathbf{0 . 5 7}$ & $\mathbf{0 . 6 2}$ & $\mathbf{0 . 7 4}$ \\
Norte & & & & & & \\
\hline Sergipe & 0.31 & 0.76 & 0.73 & 0.53 & 0.61 & 0.71 \\
\hline Brasil & $\mathbf{0 . 6 3}$ & $\mathbf{1 . 4 3}$ & $\mathbf{1 . 3 1}$ & $\mathbf{0 . 6 8}$ & $\mathbf{0 . 7 0}$ & $\mathbf{0 . 7 8}$ \\
\hline Nordeste & 0.31 & 0.69 & 0.65 & 0.57 & 0.65 & 0.78 \\
\hline
\end{tabular}


Table B4: Poverty Measures and Inequality based on DHB tables

\begin{tabular}{|c|c|c|c|c|c|c|c|c|c|}
\hline \multirow[t]{2}{*}{ ESTADO } & \multicolumn{3}{|c|}{$\begin{array}{l}\text { PORCENTAGEM DE } \\
\text { PESSOAS COM RENDA } \\
\text { INSUFICIENTE (PO ) }\end{array}$} & \multicolumn{3}{|c|}{$\begin{array}{c}\text { INSUFICIÊNCIA } \\
\text { MÉDIA DE } \\
\text { RENDA (P1 ) }\end{array}$} & \multicolumn{3}{|c|}{$\begin{array}{c}\text { GRAU DE } \\
\text { DESIGUALDADE } \\
\text { NA POPULAÇÃO COM } \\
\text { RENDA INSUFICIENTE } \\
\text { (P2) }\end{array}$} \\
\hline & 1970 & 1980 & 1991 & 1970 & 1980 & 1991 & 1970 & 1980 & 1991 \\
\hline Alagoas & 88.14 & 69.59 & 72.02 & 0.57 & 0.36 & 0.41 & 0.42 & 0.22 & 0.28 \\
\hline Bahia & 84.95 & 60.34 & 71.55 & 0.54 & 0.29 & 0.42 & 0.39 & 0.18 & 0.29 \\
\hline Ceará & 90.04 & 70.23 & 72.78 & 0.64 & 0.39 & 0.43 & 0.49 & 0.26 & 0.30 \\
\hline Maranhão & 90.06 & 74.17 & 79.10 & 0.55 & 0.40 & 0.48 & 0.38 & 0.27 & 0.34 \\
\hline Paraíba & 91.79 & 73.10 & 73.67 & 0.66 & 0.41 & 0.43 & 0.52 & 0.28 & 0.30 \\
\hline Pernambuco & 84.19 & 60.02 & 65.17 & 0.54 & 0.30 & 0.37 & 0.40 & 0.18 & 0.25 \\
\hline Piauí & 94.50 & 80.17 & 78.14 & 0.69 & 0.49 & 0.49 & 0.54 & 0.36 & 0.35 \\
\hline $\begin{array}{l}\text { Rio Grande do } \\
\text { Norte }\end{array}$ & 89.98 & 65.97 & 66.87 & 0.63 & 0.35 & 0.38 & 0.49 & 0.23 & 0.26 \\
\hline Sergipe & 87.13 & 62.54 & 66.52 & 0.57 & 0.31 & 0.36 & 0.41 & 0.19 & 0.24 \\
\hline Brasil & 67.90 & 39.47 & 45.46 & 0.39 & 0.18 & 0.24 & 0.27 & 0.11 & 0.16 \\
\hline Nordeste & 87.85 & 66.53 & 71.68 & 0.58 & 0.35 & 0.42 & 0.43 & 0.23 & 0.29 \\
\hline
\end{tabular}


Appendix B

Appendix B: Poverty Indices and Inequality Measures based on PNAD 1981 - 1999

Table B5

\begin{tabular}{lrrrrrrrrr}
\hline P0 & 1981 & 1985 & 1988 & 1990 & 1993 & 1995 & 1997 & 1998 & 1999 \\
\hline Brazil & 24.4 & 26.0 & 25.1 & 30.3 & 29.7 & 21.8 & 21.9 & 21.6 & 22.4 \\
NE & 49.8 & 51.9 & 51.9 & 58.7 & 56.7 & 44.6 & 46.1 & 43.5 & 44.3 \\
São Paulo & 6.6 & 8.3 & 6.5 & 8.8 & 12.5 & 7.1 & 7.4 & 7.8 & 8.6 \\
Maranhão & 64.0 & 62.8 & 56.1 & 64.5 & 65.4 & 54.4 & 58.2 & 54.1 & 52.0 \\
Piauí & 69.3 & 69.8 & 68.1 & 71.5 & 62.1 & 51.6 & 57.6 & 50.2 & 51.8 \\
Ceará & 59.1 & 58.6 & 58.0 & 65.8 & 57.5 & 47.2 & 47.6 & 45.2 & 46.7 \\
Rio Grande do Norte & 49.4 & 55.7 & 47.7 & 57.0 & 54.5 & 40.4 & 39.8 & 38.3 & 39.7 \\
Paraíba & 58.3 & 57.0 & 57.4 & 60.7 & 56.9 & 40.8 & 42.9 & 40.5 & 39.4 \\
Pernambuco & 40.8 & 44.5 & 45.4 & 51.8 & 53.9 & 39.5 & 42.5 & 39.7 & 41.6 \\
Alagoas & 42.8 & 45.7 & 49.5 & 59.7 & 58.5 & 46.2 & 45.9 & 44.1 & 47.2 \\
Sergipe & 46.2 & 46.3 & 48.9 & 50.3 & 47.5 & 41.5 & 40.7 & 38.0 & 41.4 \\
Bahia & 40.7 & 44.7 & 47.7 & 54.9 & 54.6 & 43.0 & 43.5 & 41.5 & 42.2 \\
\hline
\end{tabular}

Table B6

\begin{tabular}{lrrrrrrrrr}
\hline P1 & $\mathbf{1 9 8 1}$ & $\mathbf{1 9 8 5}$ & $\mathbf{1 9 8 8}$ & $\mathbf{1 9 9 0}$ & $\mathbf{1 9 9 3}$ & $\mathbf{1 9 9 5}$ & $\mathbf{1 9 9 7}$ & $\mathbf{1 9 9 8}$ & $\mathbf{1 9 9 9}$ \\
\hline Brazil & 9.7 & 10.5 & 10.5 & 13.0 & 14.5 & 10.6 & 11.0 & 10.6 & 10.8 \\
NE & 22.0 & 23.8 & 24.1 & 28.5 & 30.0 & 21.4 & 22.4 & 20.7 & 21.2 \\
São Paulo & 2.0 & 2.6 & 2.1 & 2.7 & 5.8 & 4.4 & 4.8 & 4.6 & 4.8 \\
Maranhão & 31.1 & 29.7 & 26.4 & 34.2 & 37.5 & 28.9 & 31.5 & 27.2 & 24.2 \\
Piauí & 37.1 & 40.7 & 40.0 & 42.2 & 35.4 & 27.4 & 29.8 & 26.4 & 26.4 \\
Ceará & 27.9 & 27.9 & 28.1 & 33.1 & 30.2 & 23.0 & 23.1 & 21.9 & 22.7 \\
Rio Grande do Norte & 21.7 & 26.5 & 21.7 & 28.1 & 27.5 & 17.9 & 19.2 & 16.9 & 19.0 \\
Paraíba & 27.1 & 27.3 & 28.2 & 30.6 & 30.9 & 19.0 & 21.1 & 18.2 & 19.4 \\
Pernambuco & 16.1 & 19.2 & 19.9 & 23.0 & 28.0 & 17.4 & 20.0 & 18.5 & 20.0 \\
Alagoas & 16.8 & 17.8 & 20.9 & 25.4 & 31.0 & 20.9 & 21.7 & 20.6 & 21.8 \\
Sergipe & 18.3 & 18.8 & 20.9 & 20.8 & 23.6 & 19.8 & 20.5 & 18.0 & 20.0 \\
Bahia & 16.2 & 18.7 & 20.5 & 25.7 & 27.9 & 20.4 & 19.9 & 19.5 & 19.8 \\
\hline
\end{tabular}

\section{Table B7}

\begin{tabular}{lrrrrrrrrr}
\hline P2 & $\mathbf{1 9 8 1}$ & $\mathbf{1 9 8 5}$ & $\mathbf{1 9 8 8}$ & $\mathbf{1 9 9 0}$ & $\mathbf{1 9 9 3}$ & $\mathbf{1 9 9 5}$ & $\mathbf{1 9 9 7}$ & $\mathbf{1 9 9 8}$ & $\mathbf{1 9 9 9}$ \\
\hline Brazil & 5.2 & 5.7 & 6.0 & 7.4 & 9.8 & 7.2 & 7.7 & 7.3 & 7.5 \\
NE & 12.5 & 13.8 & 14.5 & 17.3 & 20.6 & 14.0 & 14.9 & 13.5 & 13.8 \\
São Paulo & 0.9 & 1.3 & 1.0 & 1.3 & 4.1 & 3.7 & 4.1 & 3.9 & 4.0 \\
Maranhão & 19.0 & 17.6 & 15.9 & 22.1 & 26.8 & 19.7 & 21.8 & 17.9 & 14.9 \\
Piaú́ & 24.2 & 28.3 & 28.3 & 29.7 & 25.6 & 19.1 & 20.5 & 17.7 & 17.7 \\
Ceará & 16.4 & 16.4 & 17.1 & 20.5 & 21.0 & 15.2 & 15.4 & 14.3 & 15.2 \\
Rio Grande do Norte & 11.9 & 15.7 & 12.7 & 16.9 & 18.2 & 11.2 & 13.2 & 10.6 & 12.6 \\
Paraíba & 15.7 & 16.2 & 17.5 & 19.2 & 21.6 & 12.3 & 14.1 & 11.4 & 12.7 \\
Pernambuco & 8.4 & 10.8 & 11.5 & 13.1 & 19.3 & 11.0 & 13.3 & 12.3 & 13.4 \\
Alagoas & 8.8 & 9.0 & 11.9 & 13.8 & 20.9 & 13.1 & 14.9 & 13.3 & 13.5 \\
Sergipe & 9.5 & 10.0 & 11.6 & 11.1 & 15.3 & 13.1 & 14.1 & 12.1 & 13.5 \\
Bahia & 8.4 & 10.1 & 11.6 & 15.0 & 18.7 & 13.2 & 12.7 & 12.7 & 12.8 \\
\hline
\end{tabular}


Appendix B

Table B8: Gini Coefficient

\begin{tabular}{lccccccccc}
\hline & $\mathbf{1 9 8 1}$ & $\mathbf{1 9 8 3}$ & $\mathbf{1 9 8 5}$ & $\mathbf{1 9 9 0}$ & $\mathbf{1 9 9 3}$ & $\mathbf{1 9 9 5}$ & $\mathbf{1 9 9 7}$ & $\mathbf{1 9 9 8}$ & $\mathbf{1 9 9 9}$ \\
\hline Brazil & 0.59 & 0.55 & 0.63 & 0.63 & 0.60 & 0.61 & 0.61 & 0.61 & 0.60 \\
NE & 0.61 & 0.57 & 0.65 & 0.65 & 0.63 & 0.61 & 0.63 & 0.62 & 0.62 \\
São Paulo & 0.52 & 0.48 & 0.55 & 0.55 & 0.54 & 0.55 & 0.55 & 0.55 & 0.55 \\
Maranhão & 0.57 & 0.51 & 0.57 & 0.55 & 0.61 & 0.58 & 0.61 & 0.61 & 0.58 \\
Piauí & 0.57 & 0.58 & 0.65 & 0.65 & 0.61 & 0.60 & 0.61 & 0.59 & 0.60 \\
Ceará & 0.61 & 0.56 & 0.67 & 0.65 & 0.62 & 0.62 & 0.64 & 0.61 & 0.62 \\
Rio Grande do Norte & 0.58 & 0.60 & 0.63 & 0.61 & 0.58 & 0.61 & 0.60 & 0.59 & 0.60 \\
Paraíba & 0.57 & 0.57 & 0.61 & 0.64 & 0.63 & 0.60 & 0.62 & 0.63 & 0.64 \\
Pernambuco & 0.58 & 0.54 & 0.63 & 0.62 & 0.61 & 0.59 & 0.60 & 0.62 & 0.62 \\
Alagoas & 0.57 & 0.50 & 0.55 & 0.60 & 0.62 & 0.65 & 0.62 & 0.61 & 0.59 \\
Sergipe & 0.55 & 0.54 & 0.62 & 0.59 & 0.60 & 0.56 & 0.58 & 0.58 & 0.61 \\
Bahia & 0.61 & 0.57 & 0.67 & 0.67 & 0.66 & 0.63 & 0.64 & 0.62 & 0.61 \\
\hline
\end{tabular}


Table B9: General Measures of Inequality

\begin{tabular}{|c|c|c|c|c|c|c|c|c|c|}
\hline Brazil & 1981 & 1983 & 1985 & 1990 & 1993 & 1995 & 1997 & 1998 & 1999 \\
\hline rel. mean dev. & 0.45 & 0.41 & 0.48 & 0.47 & 0.45 & 0.46 & 0.46 & 0.46 & 0.46 \\
\hline coef. of var. & 1.77 & 1.38 & 2.13 & 2.14 & 1.82 & 1.96 & 2.03 & 2.04 & 1.90 \\
\hline Sd. of logs & 1.11 & 1.06 & 1.20 & 1.18 & 1.15 & 1.12 & 1.14 & 1.12 & 1.11 \\
\hline Gini & 0.59 & 0.55 & 0.63 & 0.63 & 0.60 & 0.61 & 0.61 & 0.61 & 0.60 \\
\hline Mehran & 0.72 & 0.69 & 0.76 & 0.76 & 0.73 & 0.74 & 0.74 & 0.74 & 0.73 \\
\hline Piesch & 0.53 & 0.48 & 0.57 & 0.56 & 0.54 & 0.55 & 0.55 & 0.55 & 0.54 \\
\hline Kakwani & 0.29 & 0.25 & 0.33 & 0.32 & 0.30 & 0.30 & 0.31 & 0.30 & 0.30 \\
\hline Theil entropy & 0.71 & 0.56 & 0.84 & 0.82 & 0.74 & 0.77 & 0.78 & 0.77 & 0.75 \\
\hline Theil mean log dev. & 0.66 & 0.57 & 0.78 & 0.76 & 0.69 & 0.70 & 0.71 & 0.70 & 0.68 \\
\hline NE & 1981 & 1983 & 1985 & 1990 & 1993 & 1995 & 1997 & 1998 & 1999 \\
\hline rel. mean dev. & 0.46 & 0.43 & 0.50 & 0.50 & 0.48 & 0.46 & 0.48 & 0.47 & 0.47 \\
\hline coef. of var. & 2.16 & 1.58 & 2.62 & 2.43 & 2.23 & 2.29 & 2.19 & 2.08 & 2.11 \\
\hline sd of logs & 1.08 & 1.03 & 1.16 & 1.14 & 1.16 & 1.07 & 1.11 & 1.07 & 1.07 \\
\hline Gini & 0.61 & 0.57 & 0.65 & 0.65 & 0.63 & 0.61 & 0.63 & 0.62 & 0.62 \\
\hline Mehran & 0.72 & 0.69 & 0.76 & 0.76 & 0.75 & 0.73 & 0.74 & 0.73 & 0.73 \\
\hline Piesch & 0.55 & 0.50 & 0.60 & 0.59 & 0.57 & 0.56 & 0.57 & 0.56 & 0.56 \\
\hline Kakwani & 0.30 & 0.27 & 0.35 & 0.34 & 0.33 & 0.31 & 0.32 & 0.31 & 0.31 \\
\hline Theil entropy & 0.80 & 0.64 & 0.98 & 0.94 & 0.88 & 0.84 & 0.85 & 0.82 & 0.83 \\
\hline Theil mean log dev. & 0.68 & 0.58 & 0.81 & 0.79 & 0.77 & 0.69 & 0.73 & 0.70 & 0.70 \\
\hline São Paulo & 1981 & 1983 & 1985 & 1990 & 1993 & 1995 & 1997 & 1998 & 1999 \\
\hline rel. mean dev. & 0.39 & 0.35 & 0.41 & 0.41 & 0.40 & 0.41 & 0.41 & 0.41 & 0.41 \\
\hline coef. of var. & 1.41 & 1.13 & 1.64 & 2.00 & 1.48 & 1.65 & 1.59 & 1.55 & 1.54 \\
\hline sd of logs & 0.97 & 0.93 & 1.00 & 1.00 & 0.98 & 0.98 & 0.98 & 0.98 & 0.97 \\
\hline Gini & 0.52 & 0.48 & 0.55 & 0.55 & 0.54 & 0.55 & 0.55 & 0.55 & 0.55 \\
\hline Mehran & 0.65 & 0.61 & 0.68 & 0.68 & 0.67 & 0.67 & 0.67 & 0.67 & 0.67 \\
\hline Piesch & 0.46 & 0.41 & 0.49 & 0.49 & 0.48 & 0.49 & 0.48 & 0.48 & 0.48 \\
\hline Kakwani & 0.23 & 0.19 & 0.25 & 0.25 & 0.24 & 0.25 & 0.25 & 0.25 & 0.25 \\
\hline Theil entropy & 0.52 & 0.42 & 0.61 & 0.64 & 0.57 & 0.61 & 0.60 & 0.59 & 0.59 \\
\hline Theil mean $\log$ dev. & 0.49 & 0.42 & 0.55 & 0.55 & 0.52 & 0.54 & 0.54 & 0.53 & 0.53 \\
\hline Maranhão & 1981 & 1983 & 1985 & 1990 & 1993 & 1995 & 1997 & 1998 & 1999 \\
\hline rel. mean dev. & 0.41 & 0.37 & 0.43 & 0.41 & 0.45 & 0.42 & 0.46 & 0.45 & 0.43 \\
\hline coef. of var. & 3.14 & 1.62 & 1.82 & 1.52 & 2.43 & 1.79 & 1.82 & 2.10 & 2.15 \\
\hline sd of $\log s$ & 1.05 & 0.89 & 1.02 & 1.02 & 1.15 & 1.07 & 1.17 & 1.06 & 0.97 \\
\hline Gini & 0.57 & 0.51 & 0.57 & 0.55 & 0.61 & 0.58 & 0.61 & 0.61 & 0.58 \\
\hline Mehran & 0.68 & 0.63 & 0.69 & 0.68 & 0.74 & 0.70 & 0.74 & 0.73 & 0.70 \\
\hline Piesch & 0.51 & 0.45 & 0.52 & 0.49 & 0.54 & 0.51 & 0.55 & 0.55 & 0.53 \\
\hline Kakwani & 0.27 & 0.22 & 0.27 & 0.25 & 0.30 & 0.27 & 0.31 & 0.31 & 0.28 \\
\hline Theil entropy & 0.83 & 0.56 & 0.70 & 0.60 & 0.83 & 0.70 & 0.77 & 0.83 & 0.78 \\
\hline Theil mean log dev. & 0.60 & 0.46 & 0.60 & 0.56 & 0.72 & 0.62 & 0.73 & 0.69 & 0.60 \\
\hline
\end{tabular}


Appendix B

\begin{tabular}{lccccccccc}
\hline Piauí & $\mathbf{1 9 8 1}$ & $\mathbf{1 9 8 3}$ & $\mathbf{1 9 8 5}$ & $\mathbf{1 9 9 0}$ & $\mathbf{1 9 9 3}$ & $\mathbf{1 9 9 5}$ & $\mathbf{1 9 9 7}$ & $\mathbf{1 9 9 8}$ & $\mathbf{1 9 9 9}$ \\
\hline rel. mean dev. & 0.41 & 0.42 & 0.49 & 0.49 & 0.45 & 0.44 & 0.45 & 0.43 & 0.44 \\
coef. of var. & 2.27 & 1.74 & 2.50 & 2.35 & 2.59 & 2.91 & 1.95 & 2.19 & 2.25 \\
sd of logs & 1.45 & 1.14 & 1.23 & 1.22 & 1.17 & 1.15 & 1.14 & 1.06 & 1.10 \\
Gini & 0.57 & 0.58 & 0.65 & 0.65 & 0.61 & 0.60 & 0.61 & 0.59 & 0.60 \\
Mehran & 0.69 & 0.71 & 0.77 & 0.77 & 0.74 & 0.72 & 0.73 & 0.72 & 0.72 \\
Piesch & 0.51 & 0.51 & 0.59 & 0.59 & 0.55 & 0.54 & 0.54 & 0.53 & 0.54 \\
Kakwani & 0.27 & 0.27 & 0.34 & 0.35 & 0.30 & 0.30 & 0.30 & 0.29 & 0.29 \\
Theil entropy & 0.75 & 0.67 & 0.95 & 0.95 & 0.87 & 0.88 & 0.78 & 0.80 & 0.80 \\
Theil mean log dev. & 0.69 & 0.65 & 0.84 & 0.84 & 0.74 & 0.71 & 0.70 & 0.66 & 0.68 \\
\hline
\end{tabular}

\begin{tabular}{lccccccccc}
\hline Ceará & $\mathbf{1 9 8 1}$ & $\mathbf{1 9 8 3}$ & $\mathbf{1 9 8 5}$ & $\mathbf{1 9 9 0}$ & $\mathbf{1 9 9 3}$ & $\mathbf{1 9 9 5}$ & $\mathbf{1 9 9 7}$ & $\mathbf{1 9 9 8}$ & $\mathbf{1 9 9 9}$ \\
\hline rel. mean dev. & 0.47 & 0.43 & 0.52 & 0.51 & 0.46 & 0.47 & 0.49 & 0.47 & 0.47 \\
coef. of var. & 1.99 & 1.48 & 3.26 & 2.24 & 2.04 & 2.06 & 2.07 & 1.97 & 2.10 \\
sd of logs & 1.06 & 1.01 & 1.17 & 1.14 & 1.15 & 1.09 & 1.14 & 1.08 & 1.08 \\
Gini & 0.61 & 0.56 & 0.67 & 0.65 & 0.62 & 0.62 & 0.64 & 0.61 & 0.62 \\
Mehran & 0.73 & 0.69 & 0.78 & 0.77 & 0.74 & 0.74 & 0.75 & 0.73 & 0.73 \\
Piesch & 0.55 & 0.50 & 0.62 & 0.60 & 0.56 & 0.56 & 0.58 & 0.56 & 0.56 \\
Kakwani & 0.31 & 0.26 & 0.37 & 0.35 & 0.31 & 0.31 & 0.33 & 0.31 & 0.31 \\
Theil entropy & 0.80 & 0.61 & 1.12 & 0.94 & 0.83 & 0.83 & 0.86 & 0.80 & 0.84 \\
Theil mean log dev. & 0.69 & 0.57 & 0.87 & 0.81 & 0.74 & 0.71 & 0.76 & 0.70 & 0.70 \\
\hline
\end{tabular}

\begin{tabular}{lccccccccc}
\hline $\begin{array}{l}\text { Rio Grande do } \\
\text { Norte }\end{array}$ & $\mathbf{1 9 8 1}$ & $\mathbf{1 9 8 3}$ & $\mathbf{1 9 8 5}$ & $\mathbf{1 9 9 0}$ & $\mathbf{1 9 9 3}$ & $\mathbf{1 9 9 5}$ & $\mathbf{1 9 9 7}$ & $\mathbf{1 9 9 8}$ & $\mathbf{1 9 9 9}$ \\
\hline rel. mean dev. & 0.43 & 0.45 & 0.48 & 0.46 & 0.43 & 0.46 & 0.46 & 0.45 & 0.45 \\
coef. of var. & 1.93 & 1.91 & 2.08 & 1.87 & 1.75 & 2.31 & 1.76 & 1.91 & 1.92 \\
sd of logs & 0.97 & 1.06 & 1.10 & 1.09 & 1.05 & 1.04 & 1.04 & 1.01 & 1.06 \\
Gini & 0.58 & 0.60 & 0.63 & 0.61 & 0.58 & 0.61 & 0.60 & 0.59 & 0.60 \\
Mehran & 0.69 & 0.71 & 0.74 & 0.73 & 0.70 & 0.73 & 0.72 & 0.71 & 0.71 \\
Piesch & 0.52 & 0.54 & 0.57 & 0.55 & 0.52 & 0.56 & 0.54 & 0.54 & 0.54 \\
Kakwani & 0.28 & 0.29 & 0.32 & 0.30 & 0.28 & 0.31 & 0.30 & 0.29 & 0.29 \\
Theil entropy & 0.72 & 0.75 & 0.86 & 0.77 & 0.69 & 0.86 & 0.75 & 0.75 & 0.76 \\
Theil mean log dev. & 0.59 & 0.65 & 0.73 & 0.68 & 0.62 & 0.69 & 0.65 & 0.63 & 0.65 \\
\hline
\end{tabular}

\begin{tabular}{lccccccccc}
\hline Paraíba & $\mathbf{1 9 8 1}$ & $\mathbf{1 9 8 3}$ & $\mathbf{1 9 8 5}$ & $\mathbf{1 9 9 0}$ & $\mathbf{1 9 9 3}$ & $\mathbf{1 9 9 5}$ & $\mathbf{1 9 9 7}$ & $\mathbf{1 9 9 8}$ & $\mathbf{1 9 9 9}$ \\
\hline rel. mean dev. & 0.42 & 0.43 & 0.46 & 0.49 & 0.47 & 0.45 & 0.47 & 0.48 & 0.49 \\
coef. of var. & 2.15 & 1.66 & 2.03 & 2.91 & 2.18 & 2.08 & 2.03 & 2.12 & 1.99 \\
sd of logs & 0.94 & 1.02 & 1.13 & 1.12 & 1.18 & 1.06 & 1.12 & 1.07 & 1.15 \\
Gini & 0.57 & 0.57 & 0.61 & 0.64 & 0.63 & 0.60 & 0.62 & 0.63 & 0.64 \\
Mehran & 0.68 & 0.69 & 0.73 & 0.76 & 0.76 & 0.72 & 0.74 & 0.74 & 0.76 \\
Piesch & 0.51 & 0.51 & 0.56 & 0.59 & 0.57 & 0.55 & 0.56 & 0.58 & 0.58 \\
Kakwani & 0.27 & 0.27 & 0.31 & 0.34 & 0.33 & 0.30 & 0.31 & 0.33 & 0.34 \\
Theil entropy & 0.74 & 0.67 & 0.82 & 0.98 & 0.88 & 0.80 & 0.82 & 0.88 & 0.86 \\
Theil mean log dev. & 0.57 & 0.59 & 0.71 & 0.78 & 0.78 & 0.68 & 0.71 & 0.73 & 0.78 \\
\hline
\end{tabular}


Appendix B

\begin{tabular}{lccccccccc}
\hline Pernambuco & $\mathbf{1 9 8 1}$ & $\mathbf{1 9 8 3}$ & $\mathbf{1 9 8 5}$ & $\mathbf{1 9 9 0}$ & $\mathbf{1 9 9 3}$ & $\mathbf{1 9 9 5}$ & $\mathbf{1 9 9 7}$ & $\mathbf{1 9 9 8}$ & $\mathbf{1 9 9 9}$ \\
\hline rel. mean dev. & 0.44 & 0.40 & 0.48 & 0.48 & 0.46 & 0.45 & 0.46 & 0.47 & 0.47 \\
coef. of var. & 2.00 & 1.51 & 2.32 & 2.02 & 1.89 & 2.04 & 1.90 & 2.18 & 2.09 \\
sd of logs & 1.02 & 0.98 & 1.12 & 1.08 & 1.15 & 1.00 & 1.05 & 1.05 & 1.07 \\
Gini & 0.58 & 0.54 & 0.63 & 0.62 & 0.61 & 0.59 & 0.60 & 0.62 & 0.62 \\
Mehran & 0.70 & 0.67 & 0.75 & 0.74 & 0.73 & 0.70 & 0.72 & 0.73 & 0.73 \\
Piesch & 0.53 & 0.48 & 0.57 & 0.56 & 0.55 & 0.53 & 0.54 & 0.56 & 0.56 \\
Kakwani & 0.28 & 0.25 & 0.33 & 0.32 & 0.31 & 0.29 & 0.30 & 0.31 & 0.31 \\
Theil entropy & 0.74 & 0.58 & 0.88 & 0.81 & 0.78 & 0.75 & 0.76 & 0.84 & 0.83 \\
Theil mean log dev. & 0.62 & 0.53 & 0.75 & 0.71 & 0.71 & 0.62 & 0.66 & 0.69 & 0.70 \\
\hline
\end{tabular}

\begin{tabular}{lccccccccc}
\hline Alagoas & $\mathbf{1 9 8 1}$ & $\mathbf{1 9 8 3}$ & $\mathbf{1 9 8 5}$ & $\mathbf{1 9 9 0}$ & $\mathbf{1 9 9 3}$ & $\mathbf{1 9 9 5}$ & $\mathbf{1 9 9 7}$ & $\mathbf{1 9 9 8}$ & $\mathbf{1 9 9 9}$ \\
\hline rel. mean dev. & 0.43 & 0.37 & 0.41 & 0.46 & 0.47 & 0.50 & 0.48 & 0.47 & 0.44 \\
coef. of var. & 2.32 & 1.42 & 1.73 & 2.35 & 2.09 & 2.33 & 2.06 & 2.00 & 1.91 \\
sd of logs & 0.93 & 0.85 & 0.95 & 0.96 & 1.10 & 1.08 & 1.08 & 1.04 & 1.00 \\
Gini & 0.57 & 0.50 & 0.55 & 0.60 & 0.62 & 0.65 & 0.62 & 0.61 & 0.59 \\
Mehran & 0.68 & 0.62 & 0.67 & 0.71 & 0.74 & 0.76 & 0.74 & 0.73 & 0.70 \\
Piesch & 0.52 & 0.44 & 0.49 & 0.55 & 0.56 & 0.60 & 0.57 & 0.55 & 0.53 \\
Kakwani & 0.27 & 0.21 & 0.25 & 0.30 & 0.32 & 0.35 & 0.32 & 0.31 & 0.28 \\
Theil entropy & 0.78 & 0.51 & 0.65 & 0.85 & 0.84 & 0.96 & 0.84 & 0.80 & 0.73 \\
Theil mean log dev. & 0.58 & 0.43 & 0.54 & 0.64 & 0.72 & 0.78 & 0.71 & 0.68 & 0.61 \\
\hline
\end{tabular}

\begin{tabular}{lccccccccc}
\hline Sergipe & $\mathbf{1 9 8 1}$ & $\mathbf{1 9 8 3}$ & $\mathbf{1 9 8 5}$ & $\mathbf{1 9 9 0}$ & $\mathbf{1 9 9 3}$ & $\mathbf{1 9 9 5}$ & $\mathbf{1 9 9 7}$ & $\mathbf{1 9 9 8}$ & $\mathbf{1 9 9 9}$ \\
\hline rel. mean dev. & 0.41 & 0.41 & 0.47 & 0.45 & 0.44 & 0.42 & 0.44 & 0.44 & 0.46 \\
coef. of var. & 1.58 & 1.43 & 2.00 & 1.97 & 2.24 & 1.49 & 1.65 & 1.88 & 2.24 \\
sd of logs & 0.92 & 0.95 & 1.07 & 0.98 & 1.06 & 1.01 & 1.07 & 1.02 & 1.07 \\
Gini & 0.55 & 0.54 & 0.62 & 0.59 & 0.60 & 0.56 & 0.58 & 0.58 & 0.61 \\
Mehran & 0.66 & 0.66 & 0.73 & 0.70 & 0.72 & 0.69 & 0.71 & 0.70 & 0.73 \\
Piesch & 0.49 & 0.48 & 0.56 & 0.53 & 0.54 & 0.50 & 0.52 & 0.52 & 0.55 \\
Kakwani & 0.25 & 0.25 & 0.31 & 0.29 & 0.29 & 0.26 & 0.28 & 0.28 & 0.31 \\
Theil entropy & 0.62 & 0.57 & 0.82 & 0.76 & 0.82 & 0.61 & 0.68 & 0.72 & 0.83 \\
Theil mean log dev. & 0.52 & 0.51 & 0.69 & 0.62 & 0.67 & 0.57 & 0.63 & 0.62 & 0.69 \\
\hline
\end{tabular}

\begin{tabular}{lccccccccc}
\hline Bahia & $\mathbf{1 9 8 1}$ & $\mathbf{1 9 8 3}$ & $\mathbf{1 9 8 5}$ & $\mathbf{1 9 9 0}$ & $\mathbf{1 9 9 3}$ & $\mathbf{1 9 9 5}$ & $\mathbf{1 9 9 7}$ & $\mathbf{1 9 9 8}$ & $\mathbf{1 9 9 9}$ \\
\hline rel. mean dev. & 0.46 & 0.43 & 0.52 & 0.52 & 0.50 & 0.48 & 0.49 & 0.47 & 0.46 \\
coef. of var. & 2.10 & 1.53 & 2.45 & 2.58 & 2.38 & 2.57 & 2.45 & 2.03 & 2.10 \\
sd of logs & 1.05 & 1.02 & 1.18 & 1.18 & 1.19 & 1.07 & 1.11 & 1.07 & 1.06 \\
Gini & 0.61 & 0.57 & 0.67 & 0.67 & 0.66 & 0.63 & 0.64 & 0.62 & 0.61 \\
Mehran & 0.73 & 0.70 & 0.78 & 0.79 & 0.77 & 0.74 & 0.76 & 0.73 & 0.73 \\
Piesch & 0.55 & 0.51 & 0.61 & 0.62 & 0.60 & 0.57 & 0.58 & 0.56 & 0.55 \\
Kakwani & 0.30 & 0.27 & 0.37 & 0.37 & 0.35 & 0.32 & 0.34 & 0.31 & 0.31 \\
Theil entropy & 0.79 & 0.63 & 1.00 & 1.02 & 0.96 & 0.90 & 0.92 & 0.82 & 0.81 \\
Theil mean log dev. & 0.67 & 0.58 & 0.85 & 0.87 & 0.83 & 0.72 & 0.77 & 0.70 & 0.68 \\
\hline
\end{tabular}


Appendix C

\section{Table C1: Poverty Profile for Brazil}

Brazil

Total

Gender

male

female

Race

white

black

mulatto

indig

asian

Age:

$<25$

25 to 45

45 to 65

$>65$

Household Characteristics

No. of $<5$

No.of 5_15

No.of $>65$

Location:

urban

rural

Working Class:

carteira

yes

no

active

yes

no

worked

yes

no

Work Sector:

Agri.

Ind.

Service

Social

Public

Other

Work Position:

employee

self-employed

employer
198119851988199019931995199719981999

$\begin{array}{lllllllll}24.4 & 26.0 & 25.1 & 30.3 & 29.7 & 21.8 & 21.9 & 21.6 & 22.4\end{array}$

$\begin{array}{lllllllll}24.3 & 25.7 & 24.9 & 29.4 & 28.9 & 20.9 & 20.7 & 20.6 & 21.4\end{array}$

$\begin{array}{lllllllll}25.1 & 27.0 & 26.1 & 34.1 & 32.5 & 24.9 & 25.5 & 24.3 & 25.2\end{array}$

$\begin{array}{lllllll}15.8 & 20.4 & 18.9 & 12.9 & 13.2 & 13.1 & 13.8\end{array}$

$\begin{array}{llllllll}34.1 & 42.3 & 36.7 & 27.0 & 27.3 & 26.5 & 28.5\end{array}$

$\begin{array}{lllllll}39.3 & 44.4 & 44.9 & 34.7 & 34.8 & 33.8 & 34.4\end{array}$

$\begin{array}{llllll}56.7 & 54.0 & 34.3 & 29.0 & 38.3\end{array}$

$\begin{array}{lllllll}5.9 & 5.1 & 10.3 & 4.8 & 7.5 & 5.0 & 7.0\end{array}$

$\begin{array}{lllllllll}21.5 & 28.5 & 28.2 & 35.5 & 46.4 & 39.2 & 41.4 & 41.5 & 42.3\end{array}$

$\begin{array}{lllllllll}26.4 & 27.7 & 26.5 & 30.0 & 33.2 & 25.0 & 24.4 & 24.8 & 26.2\end{array}$

$\begin{array}{lllllllll}22.4 & 23.8 & 22.5 & 27.0 & 25.4 & 17.9 & 18.0 & 17.4 & 17.8\end{array}$

$\begin{array}{lllllllll}23.7 & 22.8 & 24.7 & 36.8 & 15.3 & 9.5 & 11.4 & 8.9 & 9.1\end{array}$

$\begin{array}{lllllllll}27.7 & 31.5 & 31.2 & 36.7 & 42.1 & 33.4 & 39.2 & 33.9 & 35.6\end{array}$

$\begin{array}{lllllllll}23.7 & 26.1 & 25.5 & 29.6 & 31.7 & 22.4 & 25.3 & 22.7 & 24.6\end{array}$

$\begin{array}{lllllllll}22.4 & 22.5 & 24.5 & 33.8 & 18.1 & 11.5 & 12.5 & 10.7 & 11.5\end{array}$

$\begin{array}{lllllllll}15.9 & 18.0 & 17.3 & 22.0 & 24.4 & 16.7 & 17.2 & 17.1 & 18.1\end{array}$ $\begin{array}{lllllllll}48.7 & 50.0 & 50.3 & 56.9 & 52.2 & 43.8 & 43.7 & 41.1 & 41.7\end{array}$

$\begin{array}{lllllllll}11.0 & 13.3 & 12.4 & 18.7 & 18.4 & 11.3 & 10.2 & 10.3 & 10.7\end{array}$

$\begin{array}{lllllllll}41.7 & 41.4 & 40.9 & 43.6 & 51.5 & 34.8 & 33.6 & 33.8 & 34.7\end{array}$

$\begin{array}{llllll}29.2 & 30.3 & 22.1 & 21.7 & 21.9 & 22.9\end{array}$

$\begin{array}{llllll}35.1 & 26.8 & 20.8 & 22.5 & 20.4 & 20.7\end{array}$

$\begin{array}{lllllllll}24.3 & 26.2 & 24.7 & 28.8 & 28.8 & 20.2 & 19.6 & 19.8 & 20.6\end{array}$ $\begin{array}{lllllllll}25.0 & 24.9 & 26.6 & 35.8 & 32.4 & 26.7 & 28.1 & 26.3 & 27.1\end{array}$

$\begin{array}{lllllllll}47.6 & 51.8 & 54.1 & 59.0 & 51.1 & 45.1 & 44.8 & 43.4 & 43.7\end{array}$

$\begin{array}{lllllllll}17.7 & 16.8 & 15.5 & 20.4 & 24.2 & 13.3 & 13.9 & 15.4 & 16.3\end{array}$

$\begin{array}{lllllllll}14.3 & 17.5 & 16.3 & 20.4 & 22.3 & 13.6 & 13.3 & 13.6 & 14.4\end{array}$

$\begin{array}{lllllllll}9.7 & 10.9 & 11.8 & 16.0 & 14.2 & 10.0 & 9.0 & 8.3 & 8.2\end{array}$

$\begin{array}{lllllllll}10.5 & 13.6 & 13.1 & 16.9 & 19.3 & 10.4 & 8.7 & 8.8 & 7.8\end{array}$

$\begin{array}{lllllllll}5.7 & 9.2 & 7.8 & 9.7 & 11.5 & 8.2 & 10.4 & 12.2 & 13.0\end{array}$

$\begin{array}{lllllllll}21.4 & 22.9 & 21.9 & 27.2 & 27.6 & 18.0 & 17.1 & 17.5 & 18.2\end{array}$ $\begin{array}{lllllllll}33.0 & 36.1 & 34.1 & 37.1 & 34.5 & 26.7 & 26.2 & 26.1 & 26.8\end{array}$

$\begin{array}{lllllllll}4.7 & 5.1 & 4.3 & 8.2 & 6.7 & 3.6 & 3.6 & 3.1 & 3.8\end{array}$ 
Brazil (continued)

Tenure

$$
\begin{aligned}
& <1 \\
& >1 \\
& 1 \text { to } 3 \\
& 3 \text { to } 5 \\
& >5
\end{aligned}
$$

Education

Read and Write

$$
\begin{aligned}
& \text { yes } \\
& \text { no }
\end{aligned}
$$

Years of Schooling:

no education or $<1$
1 to 4
4 to 8
8 to 12
more than 12
NA

Waste Disposal

Water Supply

collected
burnt
dumped on unused land, river, sea
other
$\begin{array}{lllllllll}44.6 & 46.8 & 49.1 & 62.2 & 62.4 & 52.3 & 56.0 & 54.6 & 55.7\end{array}$

piped not piped NA

Sanitation

Sew.Sys. \& Sep. Tank 1
Septic Tank 2
Rudimental Cespit
Drain
River or Lake
Other
NA
none

Electricity

$$
\text { yes }
$$$$
\text { no }
$$

Fridge:

$$
\begin{aligned}
& \text { yes } \\
& \text { no }
\end{aligned}
$$

Cooker:

$$
\begin{aligned}
& \text { yes } \\
& \text { no }
\end{aligned}
$$

Radio:

$$
\text { yes }
$$$$
\text { no }
$$

TV:

$$
\text { yes }
$$$$
\text { no }
$$

$\begin{array}{rrrrrrrrr}15.9 & 17.8 & 17.2 & 21.6 & 24.3 & 17.1 & 17.3 & 17.3 & 18.4 \\ 47.7 & 50.3 & 52.2 & 60.5 & 51.8 & 41.6 & 43.7 & 41.6 & 41.8 \\ & & & & & & & & \\ 45.5 & 48.1 & 48.9 & 58.4 & 48.5 & 38.8 & 39.9 & 38.5 & 38.6 \\ 29.9 & 33.0 & 32.6 & 38.7 & 33.1 & 23.9 & 25.0 & 24.6 & 25.9 \\ 13.2 & 16.5 & 17.4 & 22.9 & 28.3 & 20.3 & 22.4 & 21.5 & 23.5 \\ 3.8 & 5.3 & 6.7 & 9.5 & 14.2 & 9.4 & 10.1 & 10.8 & 11.7 \\ 0.4 & 0.7 & 0.6 & 1.1 & 2.8 & 1.5 & 2.4 & 2.0 & 1.9 \\ 12.1 & 15.2 & 12.5 & 41.9 & 26.7 & 14.4 & 18.4 & 16.1 & 24.6\end{array}$

$\begin{array}{lllllllll}8.4 & 11.3 & 11.0 & 15.9 & 19.8 & 13.2 & 14.7 & 14.9 & 16.4\end{array}$ $\begin{array}{lllllllll}29.1 & 33.6 & 36.7 & 46.2 & 45.4 & 37.1 & 40.1 & 39.6 & 40.9\end{array}$ $\begin{array}{lllllllll}9.1 & 12.2 & 7.3 & 11.4 & 40.4 & 36.9 & 35.2 & 37.1 & 41.6\end{array}$

198119851988199019931995199719981999

$\begin{array}{llllll}28.7 & 28.8 & 20.4 & 19.8 & 19.9 & 20.6 \\ 28.4 & 26.6 & 19.1 & 18.7 & 18.6 & 19.3 \\ 26.7 & 28.5 & 19.2 & 18.3 & 18.1 & 20.0 \\ 23.9 & 26.6 & 17.8 & 17.1 & 17.1 & 17.3 \\ 29.1 & 25.7 & 19.3 & 19.1 & 19.0 & 19.3\end{array}$

$\begin{array}{lllllllll}11.6 & 14.9 & 14.7 & 19.9 & 19.7 & 13.2 & 14.4 & 20.8 & 21.7\end{array}$ $\begin{array}{lllllllll}34.9 & 41.7 & 42.1 & 50.8 & 27.0 & 20.5 & 20.4 & 14.7 & 15.9\end{array}$ $\begin{array}{lllllllll}57.9 & 63.8 & 64.1 & 74.4 & 62.6 & 53.4 & 57.7 & 55.3 & 56.8\end{array}$

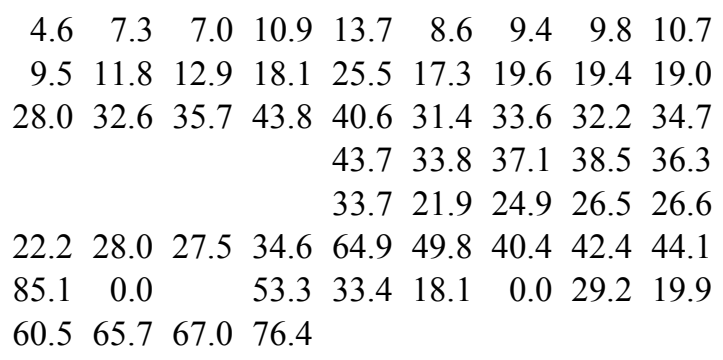

$\begin{array}{lllllllll}14.0 & 17.4 & 18.5 & 24.1 & 25.7 & 18.5 & 19.3 & 19.3 & 20.4\end{array}$ $\begin{array}{lllllllll}56.2 & 62.6 & 66.4 & 75.1 & 67.3 & 60.1 & 61.8 & 59.9 & 60.1\end{array}$

$\begin{array}{lllllllll}8.1 & 10.3 & 11.4 & 16.0 & 17.9 & 12.2 & 14.2 & 14.6 & 15.6\end{array}$ $\begin{array}{lllllllll}46.4 & 52.3 & 55.4 & 65.2 & 60.1 & 50.4 & 55.4 & 53.5 & 55.6\end{array}$

$\begin{array}{lllllllll}21.7 & 24.0 & 24.1 & 28.8 & 29.1 & 21.3 & 21.5 & 21.3 & 22.2\end{array}$ $\begin{array}{lllllllll}60.0 & 63.1 & 61.3 & 73.2 & 61.6 & 54.3 & 52.3 & 48.3 & 49.7\end{array}$

$\begin{array}{lllllll}20.4 & 25.1 & 25.4 & 19.1 & 19.7 & 19.5 & 20.3\end{array}$ $\begin{array}{lllllll}47.5 & 58.6 & 54.6 & 43.4 & 43.3 & 41.5 & 41.4\end{array}$

$\begin{array}{lllllll}13.5 & 18.2 & 21.0 & 15.6 & 17.8 & 17.9 & 18.9\end{array}$ $\begin{array}{lllllll}54.9 & 64.2 & 57.5 & 48.9 & 49.9 & 48.1 & 48.3\end{array}$ 
Brazil (continued) Housing Status:

own, paid
own, still paying
rented
ceded
other

Durable House
198119851988199019931995199719981999

$\begin{array}{rrrrrrrrr}28.2 & 29.3 & 28.2 & 33.1 & 31.0 & 23.1 & 23.4 & 23.0 & 23.4 \\ 5.9 & 7.3 & 7.5 & 9.6 & 14.9 & 9.3 & 9.7 & 8.9 & 10.4 \\ 12.5 & 15.0 & 14.0 & 17.2 & 20.2 & 12.8 & 12.7 & 12.5 & 13.6 \\ 37.2 & 39.8 & 38.5 & 44.5 & 41.4 & 31.5 & 30.3 & 30.4 & 32.4 \\ 16.9 & 16.7 & 16.3 & 23.5 & 35.5 & 25.3 & 23.0 & 25.4 & 26.4 \\ & & & & & & & & \\ 20.3 & 22.5 & 22.2 & 27.7 & 27.3 & 19.6 & 20.0 & 19.6 & 20.6 \\ 67.7 & 72.5 & 69.1 & 78.7 & 75.3 & 68.0 & 73.3 & 68.7 & 69.7\end{array}$




\section{Table C2: Poverty Profile for Northeast}

\section{Northeast}

Total

Gender

male

female

Race

white

black

mulatto

indig

asian

Age:

$<25$

25 to 45

45 to 65

$>65$

Household Characteristics

No. of $<5$

No .of 5_15

No. of $>65$

Location:

urban

rural

Working Class:

carteira

yes

no

active

yes

no

worked

yes

no

Work Sector:

Agri.

Ind.

Service

Social

Public

Other

Work Position:

employee

self-employed employer
198119851988199019931995199719981999

$\begin{array}{lllllllll}49.8 & 51.9 & 51.9 & 58.7 & 56.7 & 44.6 & 46.1 & 43.5 & 44.3\end{array}$

$\begin{array}{lllllllll}50.3 & 52.7 & 52.2 & 58.1 & 57.1 & 44.5 & 45.7 & 43.8 & 44.5\end{array}$

$\begin{array}{lllllllll}47.3 & 48.6 & 50.7 & 60.6 & 55.4 & 45.0 & 47.0 & 42.5 & 43.8\end{array}$

$$
\begin{array}{lllllll}
42.8 & 49.3 & 44.8 & 34.7 & 36.7 & 33.4 & 34.7 \\
57.8 & 67.1 & 61.4 & 47.5 & 48.2 & 47.6 & 48.7 \\
55.5 & 62.2 & 61.5 & 48.7 & 50.4 & 47.9 & 48.7 \\
& & 74.8 & 67.8 & 41.4 & 45.0 & 37.9 \\
24.5 & 12.8 & 51.6 & 33.3 & 38.0 & 30.4 & 32.9
\end{array}
$$

$\begin{array}{lllllllll}43.8 & 53.9 & 53.5 & 61.5 & 75.6 & 64.3 & 66.5 & 63.2 & 66.1\end{array}$ $\begin{array}{lllllllll}53.8 & 56.2 & 54.7 & 58.8 & 63.0 & 51.6 & 51.5 & 50.4 & 51.4\end{array}$ $\begin{array}{lllllllll}48.5 & 50.8 & 50.5 & 56.5 & 54.0 & 41.0 & 41.9 & 39.6 & 40.2\end{array}$ $\begin{array}{lllllllll}42.8 & 40.1 & 45.1 & 61.2 & 31.6 & 19.4 & 26.2 & 18.2 & 18.9\end{array}$

$\begin{array}{lllllllll}55.1 & 60.8 & 58.9 & 65.5 & 71.3 & 61.6 & 67.9 & 60.0 & 61.7\end{array}$ $\begin{array}{lllllllll}51.0 & 53.9 & 53.3 & 59.1 & 60.3 & 46.2 & 52.3 & 45.7 & 48.8\end{array}$ $\begin{array}{lllllllll}42.4 & 42.5 & 46.6 & 58.4 & 37.3 & 24.3 & 28.9 & 23.1 & 23.9\end{array}$

$\begin{array}{lllllllll}38.7 & 40.3 & 41.4 & 48.5 & 49.5 & 37.1 & 38.9 & 36.7 & 38.1\end{array}$ $\begin{array}{lllllllll}63.3 & 67.2 & 66.6 & 73.9 & 70.4 & 59.1 & 60.6 & 56.9 & 56.9\end{array}$

$\begin{array}{lllllllll}28.0 & 32.1 & 32.4 & 45.1 & 45.0 & 33.9 & 31.0 & 30.5 & 30.4\end{array}$ $\begin{array}{lllllllll}67.3 & 64.9 & 67.1 & 70.2 & 78.9 & 60.1 & 60.1 & 58.3 & 60.8\end{array}$

$\begin{array}{llllll}57.5 & 59.0 & 46.6 & 47.2 & 45.2 & 46.5\end{array}$ $\begin{array}{llllll}63.5 & 47.3 & 36.7 & 41.9 & 37.1 & 36.4\end{array}$

$\begin{array}{lllllllll}50.2 & 53.3 & 52.1 & 57.4 & 58.0 & 45.3 & 45.6 & 43.8 & 44.9\end{array}$ $\begin{array}{lllllllll}48.3 & 46.4 & 51.1 & 63.1 & 52.7 & 42.5 & 47.4 & 42.7 & 42.9\end{array}$

$\begin{array}{lllllllll}63.3 & 71.5 & 72.1 & 77.1 & 73.1 & 64.4 & 66.2 & 62.6 & 63.1\end{array}$ $\begin{array}{lllllllll}50.8 & 43.9 & 44.7 & 53.7 & 59.4 & 39.4 & 39.5 & 42.4 & 44.0\end{array}$ $\begin{array}{lllllllll}34.8 & 36.0 & 36.4 & 42.6 & 46.8 & 33.0 & 33.9 & 31.8 & 33.3\end{array}$ $\begin{array}{lllllllll}26.9 & 27.5 & 30.7 & 36.2 & 32.8 & 24.3 & 24.1 & 21.1 & 19.9\end{array}$ $\begin{array}{lllllllll}24.2 & 29.4 & 30.1 & 39.0 & 40.9 & 25.6 & 22.1 & 21.4 & 18.4\end{array}$ $\begin{array}{llllllllll}18.5 & 29.9 & 23.3 & 19.2 & 32.2 & 24.2 & 30.8 & 28.7 & 34.0\end{array}$

$\begin{array}{lllllllll}48.7 & 49.3 & 50.3 & 57.8 & 58.5 & 43.4 & 42.2 & 41.3 & 42.8\end{array}$ $\begin{array}{lllllllll}54.3 & 60.8 & 57.3 & 61.4 & 60.6 & 50.1 & 51.9 & 49.5 & 49.5\end{array}$ $\begin{array}{lllllllll}17.7 & 18.1 & 14.9 & 23.8 & 21.0 & 9.9 & 11.5 & 9.7 & 11.1\end{array}$ 


\section{Northeast}

Tenure

$<1$

$>1$

1 to 3

3 to 5

$>5$

Education

Read and Write

yes

no

Years of Schooling:

no education or $<1$

1 to 4

4 to 8

8 to 12

more than 12

NA

Waste Disposal

collected

burnt

dumped on unused land, river, sea other

Water Supply

piped

not piped

NA

Sanitation

Sew.Sys. \& Sep. Tank 1

Septic Tank 2

Rudimental Cespit

Drain

River or Lake

Other

NA

none

Electricity

yes

no

Fridge:

yes

no

Cooker:

yes

no

Radio:

yes

no

TV:

yes

no
198119851988199019931995199719981999

\author{
$\begin{array}{llllll}57.2 & 57.9 & 45.3 & 45.8 & 43.7 & 44.8\end{array}$ \\ $\begin{array}{llllll}56.3 & 54.8 & 43.2 & 44.4 & 41.8 & 43.3\end{array}$ \\ $\begin{array}{llllll}54.8 & 59.8 & 45.1 & 45.7 & 41.7 & 45.3\end{array}$ \\ $\begin{array}{llllll}51.7 & 55.1 & 43.9 & 43.9 & 41.4 & 41.9\end{array}$ \\ $\begin{array}{llllll}56.8 & 53.1 & 42.5 & 44.2 & 42.1 & 42.6\end{array}$
}

$\begin{array}{lllllllll}36.9 & 39.4 & 38.9 & 44.4 & 49.4 & 37.9 & 38.4 & 36.9 & 38.5\end{array}$

$\begin{array}{lllllllll}63.1 & 65.1 & 68.1 & 76.4 & 68.3 & 55.5 & 59.6 & 55.5 & 55.2\end{array}$

$\begin{array}{lllllllll}62.5 & 65.0 & 66.9 & 75.5 & 66.8 & 54.2 & 57.6 & 54.2 & 53.7\end{array}$

$\begin{array}{lllllllll}53.9 & 57.5 & 57.9 & 64.8 & 64.2 & 50.0 & 52.6 & 50.0 & 52.1\end{array}$

$\begin{array}{lllllllll}32.3 & 35.9 & 38.8 & 47.4 & 54.2 & 43.1 & 46.4 & 42.8 & 45.0\end{array}$

$\begin{array}{lllllllll}10.5 & 13.5 & 17.4 & 22.3 & 29.7 & 20.2 & 22.5 & 21.6 & 23.0\end{array}$

$\begin{array}{lllllllll}1.4 & 1.6 & 2.0 & 3.4 & 7.3 & 3.8 & 3.5 & 3.3 & 2.9\end{array}$

$\begin{array}{lllllllll}25.5 & 27.2 & 31.4 & 57.9 & 56.2 & 37.8 & 49.2 & 46.2 & 53.0\end{array}$

$\begin{array}{lllllllll}25.8 & 29.2 & 30.3 & 38.6 & 42.9 & 31.2 & 34.0 & 32.4 & 34.7\end{array}$

$\begin{array}{lllllllll}53.5 & 55.3 & 58.1 & 65.6 & 69.2 & 56.7 & 60.8 & 57.6 & 57.9\end{array}$

$\begin{array}{lllllllll}57.6 & 57.5 & 62.0 & 74.2 & 71.4 & 59.7 & 63.4 & 60.4 & 60.2\end{array}$

$\begin{array}{lllllllll}13.3 & 26.0 & 13.7 & 34.8 & 60.4 & 51.2 & 52.8 & 54.5 & 62.4\end{array}$

$\begin{array}{lllllllll}30.7 & 34.0 & 35.5 & 43.6 & 42.0 & 30.9 & 33.3 & 35.9 & 37.8\end{array}$

$\begin{array}{lllllllll}51.8 & 62.1 & 62.1 & 70.8 & 43.5 & 37.4 & 35.9 & 32.1 & 33.7\end{array}$

$\begin{array}{lllllllll}65.3 & 69.1 & 70.5 & 79.5 & 72.5 & 60.7 & 65.2 & 61.7 & 62.3\end{array}$

$\begin{array}{lllllllll}13.6 & 14.7 & 17.9 & 26.5 & 30.7 & 23.2 & 24.3 & 23.0 & 24.8\end{array}$

$\begin{array}{llllllllll}19.1 & 23.1 & 27.9 & 34.9 & 40.7 & 30.8 & 31.5 & 31.2 & 31.0\end{array}$

$\begin{array}{lllllllll}43.2 & 45.6 & 48.1 & 58.2 & 57.9 & 43.8 & 47.8 & 44.6 & 47.1\end{array}$

$\begin{array}{lllll}68.4 & 50.7 & 56.8 & 55.7 & 54.4\end{array}$

$\begin{array}{lllll}60.1 & 39.1 & 44.3 & 39.3 & 46.8\end{array}$

$\begin{array}{lllllllll}37.2 & 40.7 & 38.5 & 53.8 & 77.1 & 55.0 & 47.9 & 68.2 & 57.2\end{array}$

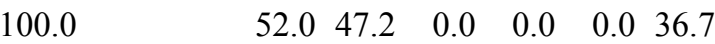

$\begin{array}{llll}66.2 & 71.1 & 73.4 & 80.5\end{array}$

$\begin{array}{lllllllll}34.3 & 37.9 & 41.5 & 49.4 & 51.4 & 39.6 & 42.0 & 39.8 & 41.3\end{array}$ $\begin{array}{lllllllll}66.3 & 72.1 & 73.5 & 81.5 & 74.6 & 64.8 & 67.5 & 65.0 & 63.7\end{array}$

$\begin{array}{lllllllll}21.1 & 23.4 & 26.5 & 33.2 & 37.1 & 27.4 & 31.9 & 30.7 & 32.1\end{array}$ $\begin{array}{lllllllll}61.9 & 66.3 & 68.5 & 77.2 & 72.9 & 60.9 & 66.1 & 62.3 & 63.8\end{array}$

$\begin{array}{lllllllll}45.4 & 48.6 & 50.3 & 56.0 & 56.0 & 43.8 & 45.5 & 43.0 & 43.9\end{array}$

$\begin{array}{lllllllll}66.2 & 69.9 & 69.9 & 80.5 & 71.5 & 63.6 & 65.1 & 59.6 & 61.8\end{array}$

$\begin{array}{lllllll}46.3 & 52.1 & 51.5 & 41.2 & 43.4 & 41.1 & 42.2\end{array}$ $\begin{array}{lllllll}64.0 & 74.1 & 70.7 & 58.4 & 59.9 & 55.8 & 55.6\end{array}$

$\begin{array}{lllllll}31.7 & 38.5 & 44.0 & 35.0 & 40.2 & 38.1 & 39.3\end{array}$ $\begin{array}{lllllll}68.5 & 77.5 & 71.9 & 61.0 & 63.0 & 60.2 & 60.5\end{array}$ 
Northeast

Housing Status:

own, paid

own, still paying

rented

ceded other

Durable House

yes

no
198119851988199019931995199719981999

$\begin{array}{lllllllll}54.2 & 55.7 & 55.5 & 61.7 & 58.3 & 45.9 & 48.2 & 45.1 & 45.3\end{array}$

$\begin{array}{lllllllll}13.3 & 17.0 & 15.8 & 21.4 & 27.4 & 17.2 & 18.5 & 14.9 & 17.0\end{array}$

$\begin{array}{lllllllll}31.5 & 35.0 & 36.7 & 44.1 & 44.8 & 31.1 & 30.6 & 29.3 & 31.4\end{array}$

$\begin{array}{lllllllll}58.5 & 63.1 & 64.2 & 71.6 & 69.9 & 58.4 & 57.7 & 56.8 & 59.4\end{array}$

$\begin{array}{lllllllll}27.6 & 31.3 & 32.3 & 46.8 & 64.8 & 44.8 & 41.5 & 40.2 & 43.3\end{array}$

$\begin{array}{lllllllll}43.7 & 46.5 & 47.5 & 54.5 & 53.3 & 41.1 & 43.0 & 40.1 & 41.5\end{array}$

$\begin{array}{lllllllll}75.0 & 79.0 & 71.9 & 85.7 & 80.5 & 71.3 & 77.6 & 74.5 & 71.8\end{array}$ 


\section{Table C3: Poverty Profile for São Paulo}

\section{São Paulo}

Total

Gender

male

female

Race

white

black

mulatto

indig

asian

Age:

$<25$

25 to 45

45 to 65

$>65$

Household Characteristics

No. of $<5$

No .of 5_15

No.of $>65$

Location:

urban

rural

Working Class:

carteira

yes

no

active

yes

no

worked

yes

no

Work Sector:

Agri.

Ind.

Service

Social

Public

Other

Work Position:

employee

self-employed employer
198119851988199019931995199719981999

$\begin{array}{lllllllll}6.6 & 8.3 & 6.5 & 8.8 & 12.5 & 7.1 & 7.4 & 7.8 & 8.6\end{array}$

$\begin{array}{lllllllll}6.2 & 7.5 & 5.6 & 8.0 & 11.4 & 5.9 & 6.0 & 6.2 & 7.1\end{array}$

$\begin{array}{lllllllll}9.4 & 12.5 & 10.3 & 12.4 & 16.7 & 11.4 & 12.0 & 12.3 & 12.6\end{array}$

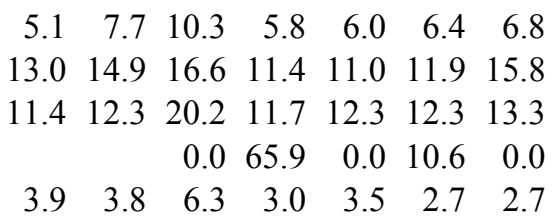

$\begin{array}{lllllllll}5.2 & 10.6 & 7.4 & 12.5 & 24.2 & 18.4 & 24.5 & 25.0 & 22.6\end{array}$

$\begin{array}{lllllllll}7.8 & 9.6 & 7.3 & 8.9 & 15.1 & 8.4 & 8.4 & 8.9 & 10.8\end{array}$

$\begin{array}{lllllllll}4.9 & 5.9 & 4.6 & 6.3 & 8.5 & 4.8 & 4.5 & 4.8 & 4.9\end{array}$

$\begin{array}{lllllllll}7.2 & 7.9 & 7.5 & 13.4 & 4.8 & 2.7 & 3.3 & 3.1 & 2.6\end{array}$

$\begin{array}{lllllllll}7.9 & 10.9 & 8.3 & 11.1 & 20.7 & 13.5 & 16.0 & 14.8 & 16.4\end{array}$

$\begin{array}{lllllllll}5.7 & 8.2 & 6.6 & 7.7 & 13.3 & 7.6 & 9.0 & 8.2 & 8.8\end{array}$

$\begin{array}{lllllllll}6.3 & 6.1 & 7.0 & 10.5 & 5.4 & 3.3 & 3.2 & 3.1 & 3.6\end{array}$

$\begin{array}{lllllllll}5.4 & 7.2 & 5.4 & 7.4 & 11.7 & 6.5 & 6.9 & 7.4 & 8.1\end{array}$

$\begin{array}{lllllllll}21.1 & 21.0 & 18.3 & 22.8 & 24.0 & 15.9 & 16.1 & 13.9 & 15.6\end{array}$

$\begin{array}{lllllllll}3.5 & 4.9 & 3.5 & 6.1 & 8.6 & 2.8 & 2.7 & 2.6 & 3.3\end{array}$

$\begin{array}{lllllllll}14.8 & 15.4 & 13.2 & 12.8 & 23.0 & 8.9 & 6.8 & 8.3 & 10.6\end{array}$

$\begin{array}{llllll}7.6 & 12.1 & 6.2 & 6.4 & 6.9 & 7.9\end{array}$

$\begin{array}{llllll}13.8 & 14.3 & 11.0 & 10.8 & 10.8 & 10.8\end{array}$

$\begin{array}{rrrrrrrrr}5.5 & 7.1 & 5.3 & 6.8 & 9.9 & 3.6 & 3.2 & 3.8 & 4.8\end{array}$

$\begin{array}{lllllllll}10.6 & 12.5 & 10.5 & 15.6 & 20.5 & 17.4 & 17.8 & 17.1 & 17.3\end{array}$

$\begin{array}{lllllllll}20.5 & 21.4 & 21.6 & 26.4 & 26.7 & 18.3 & 14.3 & 12.6 & 15.2\end{array}$

$\begin{array}{lllllllll}3.8 & 5.1 & 3.4 & 4.7 & 7.6 & 1.9 & 2.5 & 3.0 & 4.3\end{array}$

$\begin{array}{lllllllll}4.5 & 7.7 & 5.3 & 6.7 & 9.3 & 2.9 & 2.7 & 3.7 & 4.3\end{array}$

$\begin{array}{lllllllll}2.1 & 2.7 & 2.1 & 3.9 & 4.2 & 1.4 & 1.1 & 1.6 & 2.4\end{array}$

$\begin{array}{lllllllll}3.7 & 4.0 & 3.1 & 3.0 & 8.4 & 2.7 & 0.9 & 0.5 & 2.8\end{array}$

$\begin{array}{lllllllll}1.1 & 0.0 & 0.0 & 1.3 & 2.6 & 0.4 & 0.7 & 0.5 & 1.3\end{array}$

$\begin{array}{lllllllll}5.9 & 7.2 & 5.5 & 7.5 & 10.9 & 4.0 & 3.4 & 3.8 & 4.9\end{array}$

$\begin{array}{lllllllll}6.1 & 8.7 & 6.8 & 6.9 & 9.1 & 3.1 & 3.3 & 4.1 & 5.1\end{array}$

$\begin{array}{lllllllll}0.4 & 1.1 & 0.0 & 0.2 & 0.2 & 0.6 & 0.4 & 0.2 & 1.5\end{array}$ 
São Paulo

Housing Status:

own, paid

own, still paying

rented

ceded

other

Durable House

yes

no

\section{9}

$\begin{array}{rrrrrrrrr}6.0 & 7.9 & 5.5 & 7.3 & 11.3 & 6.2 & 7.0 & 7.2 & 7.7 \\ 3.0 & 3.1 & 3.2 & 3.4 & 10.2 & 7.4 & 6.7 & 7.6 & 7.9 \\ 5.1 & 6.9 & 4.5 & 6.0 & 11.1 & 5.8 & 5.3 & 5.9 & 7.0 \\ 15.9 & 17.3 & 16.6 & 21.2 & 21.3 & 13.0 & 12.9 & 13.1 & 14.8 \\ 6.9 & 9.9 & 7.6 & 14.7 & 14.3 & 5.3 & 12.7 & 18.2 & 20.5 \\ & & & & & & & & \\ 6.3 & 7.8 & 6.1 & 8.4 & 12.1 & 6.9 & 7.2 & 7.6 & 8.2 \\ 25.4 & 36.9 & 14.3 & 13.5 & 42.1 & 18.0 & 41.6 & 12.6 & 72.7\end{array}$




\section{Table C4: Poverty Profile for Maranhão}

\section{Maranhão}

Total

Gender

male

female

Race

white

black

mulatto

indig

asian

Age:

$<25$

25 to 45

45 to 65

$>65$

Household Characteristics

No. of $<5$

No .of 5_15

No. of $>65$

Location:

urban

rural

Working Class:

carteira

yes

no

active

yes

no

worked

yes

no

Work Sector:

Agri.

Ind.

Service

Social

Public

Other

Work Position:

employee

self-employed

employer
198119851988199019931995199719981999

$\begin{array}{lllllllll}64.0 & 62.8 & 56.1 & 64.5 & 65.4 & 54.4 & 58.2 & 54.1 & 52.0\end{array}$

$\begin{array}{lllllllll}64.0 & 62.9 & 55.6 & 63.7 & 65.0 & 53.0 & 57.5 & 55.7 & 52.7\end{array}$

$\begin{array}{lllllllll}64.2 & 62.2 & 58.2 & 67.9 & 66.9 & 59.2 & 60.2 & 49.9 & 49.7\end{array}$

$$
\begin{aligned}
& \begin{array}{lllllll}
49.2 & 56.7 & 52.1 & 38.8 & 45.7 & 42.1 & 43.7
\end{array} \\
& \begin{array}{lllllll}
59.3 & 68.0 & 80.7 & 56.0 & 59.3 & 51.1 & 65.8
\end{array} \\
& \begin{array}{llllllll}
57.8 & 67.0 & 68.1 & 59.4 & 61.7 & 58.5 & 53.3
\end{array} \\
& \begin{array}{llll}
75.0 & 50.0 & 0.0 & 50.0
\end{array} \\
& \begin{array}{llll}
80.0 & 100.0 & 25.0 & 50.0
\end{array}
\end{aligned}
$$

$\begin{array}{lllllllll}58.8 & 62.7 & 52.4 & 64.4 & 79.2 & 80.0 & 74.2 & 78.8 & 75.8\end{array}$ $\begin{array}{lllllllll}66.2 & 66.5 & 59.9 & 63.1 & 69.9 & 61.9 & 61.0 & 60.3 & 58.3\end{array}$ $\begin{array}{lllllllll}63.5 & 62.2 & 52.3 & 64.1 & 64.4 & 50.2 & 58.8 & 49.2 & 48.0\end{array}$ $\begin{array}{lllllllll}60.3 & 50.7 & 51.2 & 70.9 & 41.1 & 20.5 & 35.1 & 26.4 & 23.0\end{array}$

$\begin{array}{lllllllll}71.1 & 70.9 & 62.8 & 68.6 & 76.9 & 72.7 & 77.0 & 69.8 & 66.5\end{array}$ $\begin{array}{lllllllll}66.6 & 64.4 & 58.5 & 63.5 & 66.4 & 52.8 & 59.5 & 51.3 & 54.8\end{array}$ $\begin{array}{lllllllll}58.3 & 52.1 & 51.8 & 64.8 & 47.5 & 25.3 & 37.0 & 35.8 & 32.6\end{array}$

$\begin{array}{lllllllll}55.2 & 49.4 & 51.2 & 53.7 & 62.0 & 49.9 & 53.5 & 47.8 & 46.9\end{array}$ $\begin{array}{lllllllll}68.7 & 69.8 & 58.9 & 71.0 & 68.4 & 58.2 & 62.2 & 59.3 & 56.4\end{array}$

$\begin{array}{lllllllll}23.5 & 37.8 & 31.4 & 39.6 & 40.8 & 25.9 & 29.5 & 21.1 & 30.1\end{array}$ $\begin{array}{lllllllll}63.2 & 64.0 & 53.5 & 62.4 & 73.7 & 62.6 & 65.5 & 60.6 & 62.1\end{array}$

$\begin{array}{llllll}63.6 & 67.0 & 56.6 & 58.6 & 56.0 & 54.2\end{array}$ $\begin{array}{llllll}70.1 & 55.7 & 42.0 & 55.5 & 41.6 & 39.6\end{array}$

$\begin{array}{lllllllll}63.7 & 63.0 & 56.1 & 63.1 & 66.3 & 56.8 & 58.4 & 55.9 & 54.3\end{array}$ $\begin{array}{lllllllll}65.4 & 61.6 & 56.1 & 71.3 & 61.8 & 44.9 & 57.4 & 47.0 & 42.7\end{array}$

$\begin{array}{lllllllll}77.0 & 77.3 & 71.5 & 81.0 & 78.6 & 70.6 & 76.0 & 72.1 & 69.3\end{array}$ $\begin{array}{lllllllll}41.3 & 46.2 & 41.4 & 45.0 & 57.8 & 40.2 & 41.1 & 41.3 & 44.9\end{array}$ $\begin{array}{llllllllll}43.3 & 38.8 & 38.6 & 44.9 & 57.5 & 41.5 & 38.3 & 38.8 & 39.6\end{array}$ $\begin{array}{llllllllll}36.7 & 46.5 & 44.0 & 42.1 & 44.1 & 26.1 & 32.6 & 24.7 & 20.7\end{array}$ $\begin{array}{lllllllll}26.7 & 35.6 & 30.9 & 35.9 & 16.2 & 21.2 & 19.4 & 19.2 & 17.0\end{array}$ $\begin{array}{lllllllll}44.2 & 26.8 & 9.1 & 18.2 & 30.8 & 18.2 & 33.3 & 11.1 & 33.3\end{array}$

$\begin{array}{lllllllll}43.2 & 53.0 & 43.9 & 54.3 & 55.7 & 44.0 & 44.7 & 41.7 & 43.9\end{array}$ $\begin{array}{lllllllll}71.9 & 69.2 & 63.6 & 70.6 & 73.8 & 63.7 & 67.1 & 64.8 & 60.0\end{array}$ $\begin{array}{lllllllll}39.1 & 19.7 & 14.3 & 33.9 & 38.1 & 12.9 & 12.1 & 7.5 & 19.1\end{array}$ 


\section{Maranhão}

Tenure

$$
\begin{aligned}
& <1 \\
& >1 \\
& 1 \text { to } 3 \\
& 3 \text { to } 5 \\
& >5
\end{aligned}
$$

Education

Read and Write

yes

no

Years of Schooling:

$$
\text { no educat } 4 \text { ion or }<1
$$

1 to 4

4 to 8

8 to 12

more than 12

NA

Waste Disposal

collected

burnt

dumped on unused land, river, sea other

Water Supply

piped

not piped

NA

Sanitation

Sew.Sys. \& Sep. Tank 1

Septic Tank 2

Rudimental Cespit

Drain

River or Lake

Other

NA

none

Electricity

yes

no

Fridge:

yes

no

Cooker:

yes

no

Radio:

yes

no

TV:

yes

no
198119851988199019931995199719981999

$\begin{array}{llllll}63.5 & 66.2 & 56.1 & 57.9 & 55.3 & 53.8 \\ 64.0 & 64.9 & 52.0 & 57.6 & 55.3 & 53.0 \\ 54.2 & 67.8 & 44.7 & 47.2 & 45.9 & 52.4 \\ 52.9 & 68.7 & 55.1 & 56.3 & 49.7 & 45.7 \\ 66.1 & 64.3 & 53.2 & 60.1 & 58.0 & 53.5\end{array}$

$\begin{array}{lllllllll}52.8 & 52.6 & 45.2 & 50.7 & 56.8 & 50.6 & 48.7 & 48.9 & 46.6\end{array}$

$\begin{array}{lllllllll}74.1 & 72.3 & 66.6 & 79.5 & 76.3 & 60.2 & 70.9 & 62.5 & 60.9\end{array}$

$\begin{array}{lllllllll}73.2 & 72.2 & 66.9 & 78.3 & 73.8 & 58.8 & 70.0 & 61.7 & 59.3\end{array}$

$\begin{array}{lllllllll}68.1 & 66.3 & 60.5 & 68.0 & 73.7 & 62.4 & 63.9 & 61.5 & 60.2\end{array}$

$\begin{array}{lllllllll}47.6 & 48.6 & 40.8 & 55.5 & 52.0 & 58.0 & 61.8 & 58.2 & 50.7\end{array}$

$\begin{array}{rrrrrrrrr}18.8 & 23.0 & 30.1 & 18.1 & 37.5 & 32.0 & 27.0 & 27.2 & 26.4\end{array}$

$\begin{array}{lllllllll}0.0 & 2.6 & 0.0 & 4.4 & 19.4 & 2.8 & 5.6 & 11.3 & 7.5\end{array}$

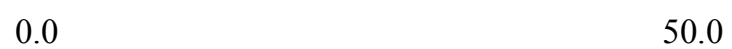

$\begin{array}{lllllllll}16.5 & 17.5 & 27.8 & 25.3 & 41.8 & 29.3 & 29.4 & 27.7 & 29.8\end{array}$

$\begin{array}{lllllllll}62.7 & 57.2 & 49.5 & 62.6 & 72.8 & 58.0 & 69.2 & 63.6 & 61.9\end{array}$

$\begin{array}{lllllllll}67.0 & 65.2 & 61.2 & 72.8 & 72.2 & 64.0 & 68.3 & 66.0 & 61.1\end{array}$

$\begin{array}{lllllllll}28.5 & 23.0 & 0.0 & 0.0 & 57.9 & 71.4 & 50.0 & 76.3 & 100.0\end{array}$

$\begin{array}{lllllllll}38.6 & 36.4 & 40.7 & 46.1 & 37.8 & 34.7 & 36.4 & 26.8 & 30.0\end{array}$

$\begin{array}{lllllllll}66.6 & 66.0 & 58.2 & 69.4 & 43.8 & 26.1 & 22.9 & 36.1 & 33.0\end{array}$

$\begin{array}{lllllllll}73.1 & 74.1 & 66.6 & 80.9 & 75.6 & 64.2 & 73.6 & 67.2 & 66.1\end{array}$

$\begin{array}{lllllllll}7.2 & 12.0 & 18.2 & 12.6 & 26.1 & 25.0 & 18.2 & 19.6 & 17.7\end{array}$ $\begin{array}{llllllllll}20.4 & 19.4 & 30.0 & 30.1 & 38.6 & 35.5 & 35.0 & 28.3 & 27.3\end{array}$

$\begin{array}{lllllllll}53.9 & 55.5 & 46.1 & 62.7 & 69.2 & 51.9 & 65.9 & 60.6 & 58.7\end{array}$

$\begin{array}{lllll}70.0 & 42.1 & 75.0 & 50.0 & 40.0\end{array}$

$\begin{array}{lllll}75.0 & 66.7 & 33.3 & 50.0 & 33.3\end{array}$

$\begin{array}{lllllllll}56.8 & 71.5 & 47.8 & 35.0 & 77.0 & 56.8 & 50.0 & 100.0 & 54.5\end{array}$

50.0

$\begin{array}{llll}75.1 & 75.4 & 72.2 & 80.4\end{array}$

$\begin{array}{lllllllll}41.4 & 42.5 & 48.1 & 50.7 & 58.9 & 46.7 & 51.0 & 48.7 & 47.0\end{array}$

$\begin{array}{lllllllll}74.2 & 75.6 & 65.2 & 82.4 & 77.4 & 71.0 & 78.9 & 72.4 & 71.6\end{array}$

$\begin{array}{lllllllll}33.7 & 31.2 & 35.8 & 34.4 & 43.4 & 34.7 & 38.0 & 35.6 & 34.6\end{array}$

$\begin{array}{lllllllll}71.9 & 72.8 & 65.2 & 80.1 & 76.6 & 66.8 & 75.2 & 70.0 & 68.6\end{array}$

$\begin{array}{lllllllll}45.2 & 52.4 & 52.1 & 55.7 & 64.6 & 51.2 & 55.7 & 51.2 & 49.8\end{array}$

$\begin{array}{lllllllll}75.7 & 75.2 & 67.2 & 82.2 & 71.2 & 74.1 & 84.9 & 72.0 & 75.0\end{array}$

$\begin{array}{lllllll}49.8 & 54.1 & 57.4 & 47.5 & 52.7 & 49.3 & 48.1\end{array}$ $\begin{array}{lllllll}63.2 & 77.2 & 75.1 & 66.1 & 67.7 & 64.0 & 61.2\end{array}$

$\begin{array}{lllllll}37.6 & 37.6 & 49.2 & 39.6 & 46.1 & 42.8 & 41.6\end{array}$ $\begin{array}{lllllll}64.3 & 79.1 & 75.6 & 67.7 & 75.4 & 70.9 & 69.0\end{array}$ 
Maranhão

Housing Status:

own, paid own, still paying rented ceded other

Durable House

$$
\text { yes }
$$$$
\text { no }
$$

198119851988199019931995199719981999

$\begin{array}{lllllllll}67.7 & 65.1 & 57.8 & 67.5 & 69.6 & 57.2 & 63.5 & 57.1 & 54.1\end{array}$

$\begin{array}{lllllllll}10.3 & 16.7 & 16.0 & 7.3 & 14.1 & 16.4 & 17.9 & 6.7 & 13.4\end{array}$

$\begin{array}{llllllllll}38.9 & 37.7 & 40.2 & 47.3 & 52.8 & 31.1 & 31.6 & 36.1 & 35.4\end{array}$

$\begin{array}{lllllllll}67.6 & 70.4 & 67.9 & 71.9 & 67.9 & 63.2 & 61.5 & 62.9 & 64.7\end{array}$

$\begin{array}{lllllllll}40.1 & 31.2 & 0.0 & 0.0 & 33.3 & 33.3 & 25.0 & 100.0 & 50.0\end{array}$

$\begin{array}{lllllllll}42.7 & 39.7 & 38.7 & 43.8 & 52.5 & 39.7 & 43.4 & 39.2 & 37.5\end{array}$

$\begin{array}{lllllllll}75.2 & 78.3 & 68.0 & 85.5 & 79.5 & 71.8 & 78.8 & 75.7 & 73.0\end{array}$ 


\section{Table C5: Poverty Profile for Piauí}

Piauí

Total

Gender

male

female

Race

white

black

mulatto

indig

asian

Age:

$<25$

25 to 45

45 to 65

$>65$

Household Characteristics

No. of $<5$

No .of 5_15

No.of $>65$

Location:

urban

rural

Working Class:

carteira

yes

no

active

yes

no

worked

yes

no

Work Sector:

Agri.

Ind.

Service

Social

Public

Other

Work Position:

employee

self-employed

employer $\begin{array}{lllllllll}1981 & 1985 & 1988 & 1990 & 1993 & 1995 & 1997 & 1998 & 1999\end{array}$

$\begin{array}{lllllllll}69.3 & 69.8 & 68.1 & 71.5 & 62.1 & 51.6 & 57.6 & 50.2 & 51.8\end{array}$

$\begin{array}{lllllllll}70.5 & 71.7 & 68.4 & 71.6 & 63.5 & 51.7 & 59.3 & 52.7 & 54.6\end{array}$

$\begin{array}{lllllllll}63.3 & 61.3 & 66.8 & 71.1 & 57.4 & 51.1 & 53.1 & 43.9 & 44.5\end{array}$

$\begin{array}{lllllll}56.6 & 53.7 & 46.0 & 37.0 & 44.2 & 34.7 & 34.9\end{array}$

$\begin{array}{llllllll}78.8 & 80.3 & 63.6 & 60.0 & 70.0 & 65.6 & 58.6\end{array}$

$\begin{array}{lllllll}69.8 & 75.7 & 66.2 & 55.0 & 60.4 & 53.7 & 56.3\end{array}$

0.0

$100.0 \quad 100.0$

$\begin{array}{lllllllll}54.2 & 71.6 & 71.3 & 64.3 & 83.3 & 68.9 & 73.8 & 71.7 & 80.0\end{array}$

$\begin{array}{lllllllll}74.4 & 74.7 & 69.9 & 71.7 & 69.0 & 60.8 & 63.2 & 61.6 & 59.8\end{array}$

$\begin{array}{lllllllll}71.5 & 71.2 & 68.0 & 70.9 & 60.1 & 49.5 & 56.1 & 45.0 & 47.4\end{array}$

$\begin{array}{lllllllll}53.5 & 48.8 & 59.1 & 76.7 & 29.1 & 15.0 & 31.4 & 17.3 & 17.2\end{array}$

$\begin{array}{lllllllll}77.6 & 78.9 & 72.8 & 77.2 & 76.5 & 68.4 & 78.9 & 69.1 & 69.9\end{array}$

$\begin{array}{lllllllll}69.5 & 75.1 & 67.2 & 73.6 & 64.7 & 53.7 & 64.2 & 53.5 & 54.3\end{array}$

$\begin{array}{lllllllll}57.0 & 55.8 & 63.0 & 75.7 & 38.5 & 23.8 & 33.7 & 22.9 & 23.0\end{array}$

$\begin{array}{lllllllll}46.9 & 52.4 & 49.9 & 54.8 & 53.5 & 40.4 & 46.9 & 41.4 & 43.8\end{array}$

$\begin{array}{lllllllll}84.8 & 84.7 & 85.6 & 88.1 & 74.4 & 67.2 & 74.4 & 63.7 & 63.8\end{array}$

$\begin{array}{lllllllll}28.8 & 42.8 & 31.8 & 42.6 & 44.4 & 37.7 & 32.9 & 33.6 & 32.0\end{array}$

$\begin{array}{lllllllll}83.6 & 73.1 & 75.6 & 75.7 & 81.1 & 63.6 & 74.0 & 65.4 & 68.9\end{array}$

$\begin{array}{llllll}71.1 & 63.9 & 54.2 & 59.5 & 53.6 & 54.8\end{array}$

$\begin{array}{llllll}73.5 & 53.0 & 37.3 & 48.7 & 36.4 & 36.2\end{array}$

$\begin{array}{lllllllll}71.4 & 73.4 & 68.6 & 71.5 & 64.2 & 54.3 & 58.1 & 53.1 & 54.4\end{array}$

$\begin{array}{lllllllll}59.8 & 52.9 & 65.4 & 71.5 & 54.6 & 40.9 & 56.2 & 41.8 & 42.0\end{array}$

$\begin{array}{lllllllll}85.5 & 88.9 & 87.6 & 88.2 & 77.1 & 71.5 & 78.3 & 68.8 & 66.8\end{array}$

$\begin{array}{lllllllll}77.9 & 66.7 & 59.6 & 67.3 & 65.3 & 46.8 & 57.3 & 52.4 & 57.1\end{array}$

$\begin{array}{lllllllll}41.2 & 49.2 & 44.2 & 52.9 & 49.1 & 39.2 & 42.8 & 38.6 & 41.7\end{array}$

$\begin{array}{lllllllll}42.3 & 37.0 & 47.8 & 35.2 & 32.8 & 23.5 & 32.1 & 19.7 & 27.3\end{array}$

$\begin{array}{lllllllll}31.6 & 24.1 & 39.2 & 52.3 & 41.4 & 33.3 & 28.6 & 21.8 & 25.0\end{array}$

$\begin{array}{lllllllll}7.6 & 42.6 & 18.8 & 22.2 & 27.3 & 12.5 & 12.5 & 63.6 & 40.0\end{array}$

$\begin{array}{lllllllll}67.2 & 61.8 & 58.5 & 63.3 & 55.3 & 44.5 & 50.7 & 44.9 & 48.8\end{array}$

$\begin{array}{lllllllll}76.7 & 83.0 & 77.0 & 81.1 & 73.4 & 63.7 & 65.2 & 60.2 & 60.0\end{array}$

$\begin{array}{lllllllll}44.0 & 35.2 & 35.0 & 55.4 & 30.9 & 25.0 & 37.1 & 11.1 & 24.5\end{array}$ 
Piauí

Tenure

$<1$

$>1$

1 to 3

3 to 5

$>5$

Education

Read and Write

yes

no

Years of Schooling:

no education or $<1$

1 to 4

4 to 8

8 to 12

more than 12

NA

Waste Disposal

collected

burnt

dumped on unused land, river, sea

other

Water Supply

piped

not piped

NA

Sanitation

Sew.Sys. \& Sep. Tank 1

Septic Tank 2

Rudimental Cespit

Drain

River or Lake

Other

NA

none

Electricity

yes

no

Fridge:

yes

no

Cooker:

yes

no

Radio:

yes

no

TV:

yes

no

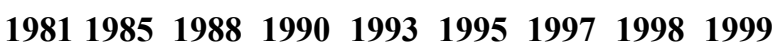

$\begin{array}{llllll}70.9 & 63.4 & 54.1 & 58.7 & 52.8 & 54.4 \\ 69.5 & 61.5 & 53.3 & 55.1 & 49.8 & 52.1 \\ 65.1 & 68.1 & 53.8 & 63.9 & 47.0 & 57.0 \\ 64.3 & 60.0 & 45.8 & 59.4 & 59.3 & 59.9 \\ 70.7 & 59.5 & 53.7 & 53.4 & 49.0 & 50.3\end{array}$

$\begin{array}{lllllllll}50.8 & 52.3 & 51.4 & 54.1 & 54.2 & 45.5 & 47.8 & 42.5 & 46.7\end{array}$ $\begin{array}{lllllllll}81.7 & 80.7 & 82.7 & 87.7 & 72.8 & 59.8 & 71.4 & 60.2 & 59.3\end{array}$

$\begin{array}{lllllllll}80.2 & 79.9 & 81.2 & 86.3 & 70.9 & 56.7 & 68.5 & 59.7 & 58.8\end{array}$

$\begin{array}{llllllllll}70.9 & 76.4 & 73.0 & 76.8 & 69.4 & 61.9 & 67.4 & 55.1 & 61.0\end{array}$

$\begin{array}{lllllllll}40.2 & 49.5 & 55.2 & 50.8 & 64.9 & 52.3 & 47.2 & 58.0 & 52.6\end{array}$

$\begin{array}{lllllllll}18.8 & 18.7 & 27.5 & 34.3 & 27.5 & 21.5 & 29.6 & 20.5 & 24.3\end{array}$

$\begin{array}{lllllllll}0.0 & 0.0 & 0.0 & 0.0 & 0.0 & 5.3 & 0.0 & 0.0 & 2.2\end{array}$

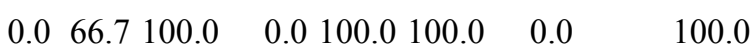

$\begin{array}{lllllllll}17.5 & 27.6 & 31.4 & 32.0 & 34.3 & 27.0 & 33.1 & 29.1 & 34.7\end{array}$ $\begin{array}{lllllllll}50.4 & 71.8 & 63.4 & 74.9 & 72.5 & 60.0 & 71.4 & 58.4 & 62.1\end{array}$

$\begin{array}{lllllllll}77.6 & 67.5 & 65.8 & 83.7 & 74.9 & 62.2 & 74.1 & 65.0 & 63.9\end{array}$

$\begin{array}{lllll}0.0 & 39.8 & 100.0 & 0.0 & 0.0\end{array}$

$\begin{array}{lllllllll}38.7 & 45.1 & 44.3 & 50.7 & 38.3 & 28.4 & 33.7 & 48.5 & 48.3\end{array}$

$\begin{array}{lllllllll}74.3 & 83.1 & 80.0 & 83.5 & 53.8 & 44.4 & 56.5 & 26.7 & 36.3\end{array}$

$\begin{array}{lllllllll}82.4 & 83.4 & 87.1 & 89.3 & 77.3 & 67.2 & 79.3 & 69.2 & 67.9\end{array}$

$\begin{array}{rrrrrrrrr} & & 0.0 & 15.4 & 0.0 & 0.0 & 25.0 & 7.2 & 8.1 \\ 25.7 & 26.3 & 27.3 & 29.1 & 37.5 & 26.1 & 31.6 & 31.1 & 35.2 \\ 53.9 & 63.8 & 56.6 & 62.7 & 70.3 & 52.3 & 65.1 & 56.6 & 54.5 \\ & & & & 0.0 & 40.0 & & 100.0 & 63.6 \\ & & & & & & & 0.0 & \\ 37.4 & 49.9 & 75.0 & 100.0 & 66.6 & & & & 50.0\end{array}$

$\begin{array}{llll}83.0 & 84.0 & 85.3 & 88.5\end{array}$

$\begin{array}{lllllllll}40.0 & 47.2 & 46.4 & 52.3 & 52.5 & 41.4 & 51.0 & 43.5 & 45.9\end{array}$

$\begin{array}{lllllllll}84.2 & 84.7 & 87.1 & 89.7 & 78.9 & 71.5 & 78.2 & 69.1 & 70.6\end{array}$

$\begin{array}{lllllllll}31.3 & 31.9 & 35.5 & 41.4 & 37.3 & 32.5 & 38.9 & 33.2 & 37.7\end{array}$

$\begin{array}{lllllllll}80.0 & 81.8 & 83.5 & 86.8 & 77.9 & 66.5 & 79.4 & 71.8 & 69.8\end{array}$

$\begin{array}{lllllllll}54.5 & 58.9 & 62.7 & 63.9 & 60.9 & 51.5 & 56.4 & 49.8 & 51.9\end{array}$

$\begin{array}{lllllllll}81.4 & 84.9 & 85.8 & 90.4 & 78.5 & 56.7 & 81.8 & 67.9 & 50.0\end{array}$

$\begin{array}{lllllll}62.0 & 67.2 & 56.5 & 48.0 & 54.1 & 46.8 & 50.0\end{array}$

$\begin{array}{lllllll}79.6 & 80.3 & 73.5 & 63.0 & 72.5 & 62.8 & 59.1\end{array}$

$\begin{array}{lllllll}35.7 & 45.3 & 44.6 & 38.0 & 47.8 & 40.6 & 43.4\end{array}$

$\begin{array}{llllllll}82.9 & 85.8 & 76.8 & 66.5 & 76.8 & 67.6 & 67.2\end{array}$ 
Appendix C

Piauí

Housing Status:

own, paid

own, still paying

rented

ceded

other

Durable House

yes

no $\begin{array}{lllllllll}1981 & 1985 & 1988 & 1990 & 1993 & 1995 & 1997 & 1998 & 1999\end{array}$

$\begin{array}{rrrrrrrrr}73.6 & 74.1 & 72.9 & 75.9 & 66.7 & 53.8 & 62.5 & 53.3 & 53.8 \\ 25.8 & 32.3 & 30.1 & 41.3 & 20.4 & 16.5 & 20.0 & 15.9 & 24.3 \\ 40.7 & 48.6 & 47.7 & 43.6 & 36.9 & 31.1 & 12.2 & 23.4 & 24.7 \\ 73.7 & 80.6 & 75.0 & 78.7 & 77.9 & 67.1 & 71.2 & 64.6 & 63.4 \\ 0.0 & 39.8 & & 75.0 & & 0.0 & & 80.0 & 52.9 \\ & & & & & & & & \\ 59.3 & 61.5 & 60.2 & 64.9 & 54.7 & 45.4 & 52.4 & 44.1 & 48.2 \\ 84.4 & 87.1 & 86.8 & 88.5 & 88.4 & 72.4 & 85.7 & 76.0 & 64.3\end{array}$




\section{Table C6: Poverty Profile for Ceará}

\section{Ceará}

Total

Gender

male

female

Race

white

black

mulatto

indig

asian

Age:

$<25$

25 to 45

45 to 65

$>65$

Household Characteristics

No. of $<5$

No .of 5_15

No.of $>65$

Location:

urban

rural

Working Class:

carteira

yes

no

active

yes

no

worked

yes

no

Work Sector:

Agri.

Ind.

Service

Social

Public

Other

Work Position:

employee

self-employed employer

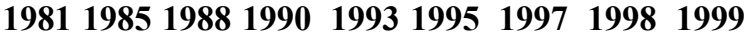

$\begin{array}{lllllllll}59.1 & 58.6 & 58.0 & 65.8 & 57.5 & 47.2 & 47.6 & 45.2 & 46.7\end{array}$

$\begin{array}{lllllllll}60.7 & 59.9 & 59.0 & 66.5 & 58.7 & 47.1 & 47.7 & 45.2 & 46.8\end{array}$

$\begin{array}{lllllllll}50.7 & 52.0 & 53.5 & 62.8 & 53.5 & 47.4 & 47.4 & 45.1 & 46.4\end{array}$

$\begin{array}{lllllll}47.9 & 56.5 & 45.6 & 36.3 & 39.5 & 34.6 & 37.7\end{array}$

$\begin{array}{llllllll}77.1 & 83.8 & 69.6 & 62.6 & 49.7 & 49.8 & 47.1\end{array}$

$\begin{array}{lllllll}61.1 & 69.6 & 62.7 & 52.0 & 51.1 & 49.8 & 51.2\end{array}$

68.1100 .0100 .0

$\begin{array}{llllll}0.0 & 41.4 & 22.1 & 41.6 & 0.0 & 15.3\end{array}$

$\begin{array}{lllllllll}53.4 & 60.8 & 61.7 & 69.7 & 74.6 & 64.8 & 69.7 & 61.6 & 67.6\end{array}$ $\begin{array}{lllllllll}63.9 & 64.3 & 61.4 & 66.5 & 64.7 & 55.0 & 53.8 & 52.8 & 55.0\end{array}$

$\begin{array}{lllllllll}58.5 & 58.0 & 57.4 & 63.9 & 55.1 & 42.2 & 42.4 & 42.9 & 42.2\end{array}$

$\begin{array}{lllllllll}48.6 & 40.1 & 48.0 & 65.9 & 31.4 & 22.7 & 24.9 & 17.4 & 18.3\end{array}$

$\begin{array}{lllllllll}65.4 & 67.1 & 65.9 & 71.1 & 73.4 & 63.9 & 68.8 & 63.1 & 61.8\end{array}$

$\begin{array}{lllllllll}58.4 & 59.7 & 57.9 & 65.3 & 61.3 & 46.5 & 50.9 & 45.4 & 50.7\end{array}$

$\begin{array}{lllllllll}49.8 & 47.1 & 48.2 & 60.7 & 37.9 & 27.2 & 29.5 & 22.7 & 26.1\end{array}$

$\begin{array}{lllllllll}44.2 & 43.9 & 46.2 & 55.3 & 49.5 & 37.8 & 38.5 & 37.5 & 39.7\end{array}$

$\begin{array}{lllllllll}77.4 & 77.8 & 75.6 & 83.3 & 75.0 & 67.5 & 69.5 & 63.5 & 62.4\end{array}$

$\begin{array}{lllllllll}34.4 & 37.1 & 35.9 & 49.2 & 46.7 & 31.8 & 28.5 & 26.6 & 28.3\end{array}$

$\begin{array}{lllllllll}81.1 & 72.9 & 76.6 & 77.5 & 80.9 & 62.4 & 61.6 & 59.2 & 58.7\end{array}$

$\begin{array}{llllll}64.6 & 60.5 & 48.6 & 48.8 & 46.6 & 48.7\end{array}$

$\begin{array}{llllll}70.5 & 45.0 & 41.3 & 43.3 & 39.3 & 38.7\end{array}$

$\begin{array}{lllllllll}60.2 & 61.0 & 58.4 & 64.5 & 59.8 & 47.3 & 47.3 & 45.3 & 48.0\end{array}$

$\begin{array}{lllllllll}54.8 & 47.0 & 56.3 & 70.4 & 50.2 & 46.8 & 48.5 & 44.9 & 42.7\end{array}$

$\begin{array}{lllllllll}73.6 & 79.5 & 78.5 & 83.7 & 72.7 & 69.5 & 67.5 & 65.7 & 66.5\end{array}$

$\begin{array}{lllllllll}70.2 & 55.1 & 52.7 & 66.2 & 68.5 & 43.3 & 47.4 & 49.6 & 44.2\end{array}$

$\begin{array}{lllllllll}38.3 & 40.3 & 38.7 & 49.2 & 45.1 & 33.6 & 35.8 & 29.4 & 36.0\end{array}$

$\begin{array}{lllllllll}33.4 & 27.9 & 38.9 & 36.9 & 40.9 & 21.8 & 24.0 & 21.9 & 24.0\end{array}$

$\begin{array}{lllllllll}13.8 & 29.0 & 26.6 & 36.3 & 42.2 & 21.3 & 19.3 & 18.1 & 15.9\end{array}$

$\begin{array}{lllllllll}19.8 & 39.2 & 35.4 & 29.2 & 34.5 & 19.6 & 34.0 & 18.3 & 36.0\end{array}$

$\begin{array}{lllllllll}65.7 & 59.0 & 62.7 & 65.8 & 64.2 & 45.5 & 44.3 & 42.7 & 42.9\end{array}$

$\begin{array}{lllllllll}52.6 & 66.3 & 55.5 & 67.5 & 56.9 & 52.1 & 53.0 & 51.3 & 54.7\end{array}$

$\begin{array}{lllllllll}30.9 & 31.2 & 12.2 & 27.9 & 25.6 & 14.0 & 22.1 & 20.0 & 16.0\end{array}$ 
Ceará

Tenure

$<1$

$>1$

1 to 3

3 to 5

$>5$

Education

Read and Write

yes

no

Years of Schooling:

no education or $<1$

1 to 4

4 to 8

8 to 12

more than 12

NA

Waste Disposal

collected

burnt

dumped on unused land, river, sea

other

Water Supply

piped

not piped

NA

Sanitation

Sew.Sys. \& Sep. Tank 1

Septic Tank 2

Rudimental Cespit

Drain

River or Lake

Other

NA

none

Electricity

yes

no

Fridge:

yes

no

Cooker:

yes

no

Radio:

yes

no

TV:

yes

no
198119851988199019931995199719981999

$\begin{array}{llllll}64.4 & 59.8 & 47.5 & 47.6 & 45.1 & 47.8 \\ 61.4 & 55.9 & 46.1 & 45.9 & 42.7 & 46.4 \\ 60.5 & 60.7 & 46.1 & 49.4 & 39.1 & 42.0 \\ 58.0 & 55.0 & 47.5 & 45.6 & 39.9 & 43.8 \\ 61.7 & 54.1 & 46.1 & 44.5 & 44.6 & 47.9\end{array}$

$\begin{array}{lllllllll}43.9 & 43.9 & 43.6 & 49.2 & 49.2 & 38.3 & 38.3 & 36.4 & 40.1\end{array}$ $\begin{array}{lllllllll}73.1 & 72.0 & 73.0 & 83.2 & 69.5 & 60.3 & 62.4 & 59.0 & 57.9\end{array}$

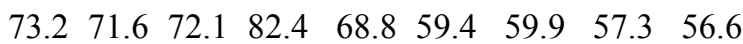
$\begin{array}{lllllllll}62.9 & 62.2 & 63.1 & 69.8 & 63.2 & 53.3 & 55.6 & 52.9 & 53.9\end{array}$ $\begin{array}{lllllllll}37.4 & 39.6 & 40.7 & 50.3 & 50.5 & 39.3 & 40.4 & 41.7 & 45.7\end{array}$ $\begin{array}{rrrrrrrrr}10.8 & 14.4 & 17.0 & 26.5 & 28.9 & 19.8 & 23.7 & 18.0 & 23.4\end{array}$

$\begin{array}{lllllllll}2.0 & 0.4 & 0.5 & 3.0 & 5.2 & 2.0 & 3.3 & 2.0 & 2.6\end{array}$ $\begin{array}{lllllllll}19.2 & 60.6 & 34.2 & 0.0 & 63.6 & 22.1 & 59.6 & 46.3 & 46.1\end{array}$

$\begin{array}{lllllllll}27.4 & 27.7 & 30.6 & 42.5 & 43.3 & 31.8 & 32.8 & 33.4 & 35.5\end{array}$ $\begin{array}{lllllllll}56.8 & 55.0 & 67.6 & 66.9 & 71.2 & 62.3 & 65.3 & 61.2 & 62.8\end{array}$ $\begin{array}{lllllllll}70.3 & 59.7 & 65.2 & 82.1 & 71.8 & 64.3 & 68.1 & 63.1 & 64.4\end{array}$ $\begin{array}{lllllllll}25.2 & 33.8 & 20.4 & 50.0 & 80.0 & 54.0 & 88.8 & 0.0 & 51.4\end{array}$ $\begin{array}{lllllllll}30.4 & 33.1 & 32.1 & 45.6 & 42.1 & 30.4 & 32.7 & 26.3 & 37.2\end{array}$ $\begin{array}{lllllllll}53.3 & 67.8 & 64.0 & 71.6 & 28.0 & 26.7 & 28.1 & 33.0 & 34.1\end{array}$ $\begin{array}{lllllllll}71.9 & 72.3 & 74.5 & 83.4 & 72.9 & 63.4 & 66.6 & 63.6 & 65.1\end{array}$

$\begin{array}{lllllllll}10.0 & 17.6 & 18.9 & 31.8 & 30.9 & 18.1 & 21.1 & 22.1 & 24.2\end{array}$ $\begin{array}{lllllllll}25.0 & 23.7 & 32.7 & 43.0 & 41.5 & 31.5 & 28.7 & 30.9 & 27.9\end{array}$ $\begin{array}{lllllllll}51.2 & 52.5 & 57.2 & 73.5 & 58.9 & 44.4 & 45.1 & 43.6 & 47.6\end{array}$ $\begin{array}{lllll}72.0 & 52.7 & 68.3 & 70.8 & 63.1\end{array}$ $\begin{array}{lllll}100.0 & 50.1 & 60.7 & 42.5 & 57.1\end{array}$ $\begin{array}{lllllllll}70.3 & 70.2 & 54.0 & 66.7 & 90.5 & 31.8 & 50.0 & 83.2 & 56.8\end{array}$ $76.177 .278 .6 \quad 86.1$

$\begin{array}{lllllllll}39.1 & 40.3 & 42.9 & 53.8 & 49.7 & 39.2 & 41.0 & 39.6 & 42.9\end{array}$ $\begin{array}{llllllllll}76.8 & 78.9 & 80.0 & 87.4 & 77.1 & 70.0 & 73.7 & 70.0 & 66.6\end{array}$ $\begin{array}{lllllllll}23.6 & 25.1 & 27.6 & 35.4 & 34.1 & 24.2 & 29.4 & 29.2 & 32.5\end{array}$

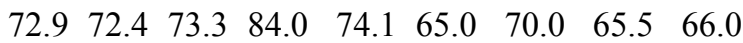
$\begin{array}{lllllllll}57.7 & 56.8 & 57.1 & 64.1 & 56.8 & 46.5 & 46.9 & 45.2 & 46.4\end{array}$

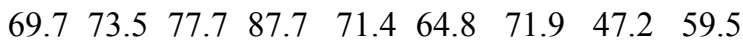
$\begin{array}{lllllll}52.0 & 60.8 & 52.4 & 44.0 & 45.1 & 43.0 & 44.7\end{array}$ $\begin{array}{lllllll}71.6 & 79.9 & 74.3 & 61.8 & 62.5 & 58.7 & 57.2\end{array}$ $\begin{array}{lllllll}35.6 & 43.6 & 44.0 & 35.1 & 39.3 & 39.6 & 41.6\end{array}$ $\begin{array}{llllllll}74.2 & 84.0 & 73.3 & 66.9 & 70.3 & 62.9 & 62.7\end{array}$ 


\section{Ceará}

Housing Status:

own, paid

own, still paying

rented

ceded

other

Durable House

yes

no
198119851988199019931995199719981999

$\begin{array}{lllllllll}61.8 & 60.7 & 60.8 & 66.7 & 57.3 & 48.6 & 48.0 & 46.3 & 47.2\end{array}$

$\begin{array}{lllllllll}16.5 & 22.4 & 20.1 & 32.1 & 38.2 & 20.1 & 22.5 & 19.8 & 17.0\end{array}$

$\begin{array}{llllllllll}37.1 & 38.1 & 41.6 & 53.6 & 43.9 & 29.1 & 30.2 & 25.3 & 30.5\end{array}$

$\begin{array}{llllllllll}76.0 & 76.9 & 73.7 & 81.6 & 74.7 & 62.7 & 67.7 & 63.6 & 63.7\end{array}$

$\begin{array}{lllllllll}30.9 & 55.0 & 52.7 & 37.4 & 64.2 & 39.0 & 44.2 & 50.9 & 43.0\end{array}$

$\begin{array}{lllllllll}53.5 & 53.1 & 53.4 & 62.1 & 54.1 & 43.3 & 44.6 & 42.4 & 44.1\end{array}$

$\begin{array}{lllllllll}84.0 & 86.2 & 94.3 & 80.0 & 62.5 & 86.6 & 100.0 & 67.5 & 71.4\end{array}$ 


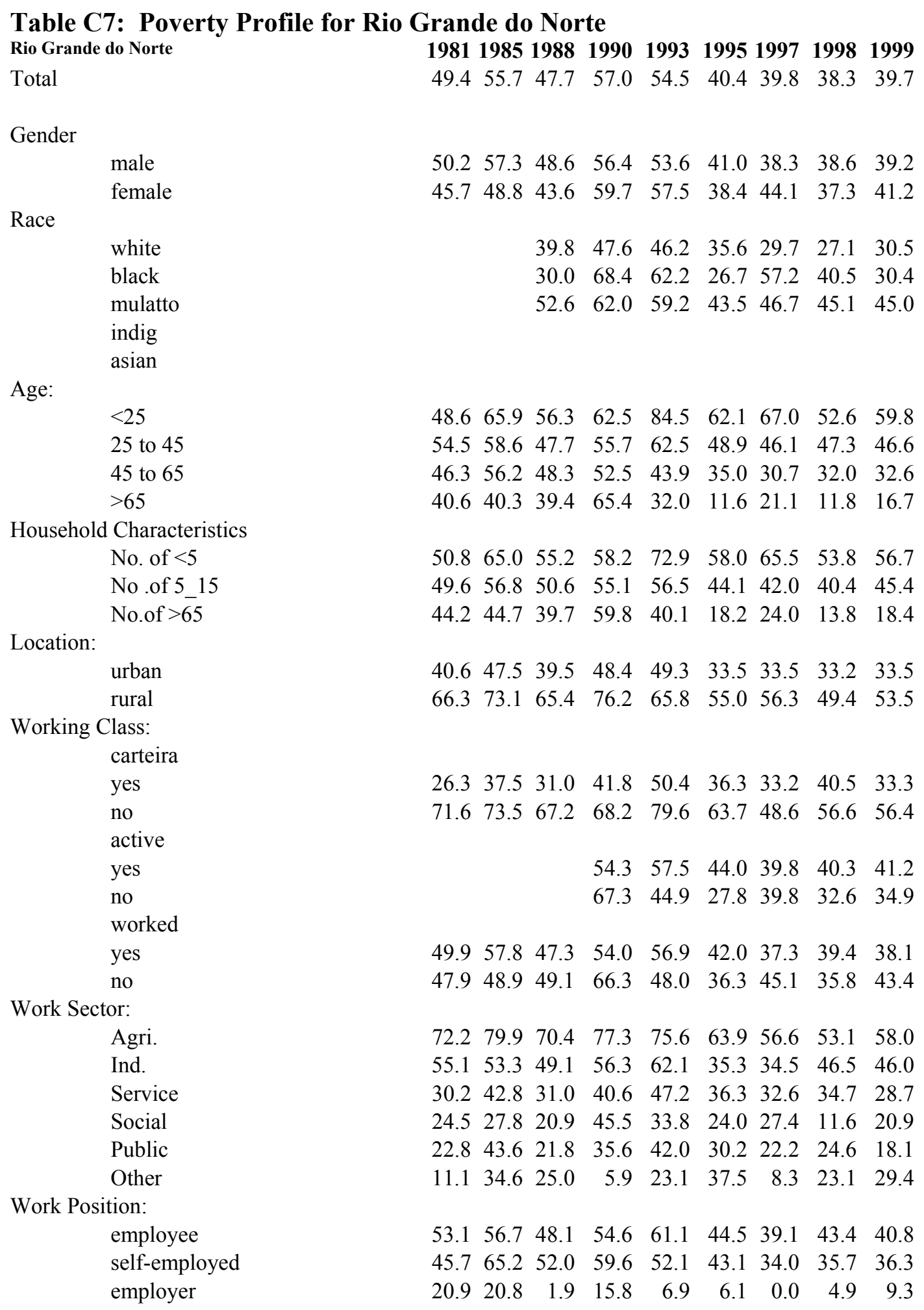


Rio Grande do Norte

Tenure

$$
\begin{aligned}
& <1 \\
& >1 \\
& 1 \text { to } 3 \\
& 3 \text { to } 5 \\
& >5
\end{aligned}
$$

Education

Read and Write

yes

no

Years of Schooling:

no education or $<1$
1 to 4
4 to 8
8 to 12
more than 12
NA

Waste Disposal

$\begin{array}{lrrrrrrrrr}\text { collected } & 33.2 & 41.8 & 30.6 & 44.3 & 47.3 & 31.1 & 33.9 & 32.0 & 33.7 \\ \text { burnt } & 57.3 & 64.4 & 67.4 & 57.5 & 69.1 & 61.1 & 60.4 & 56.0 & 65.3 \\ \text { dumped on unused land, river, sea } & 65.5 & 67.6 & 63.7 & 80.6 & 72.4 & 62.0 & 57.8 & 59.3 & 56.8 \\ \text { other } & 33.5 & 0.0 & 0.0 & 0.0 & 100.0 & 0.0 & 33.3 & 50.0 & 50.0\end{array}$

Water Supply

$$
\begin{aligned}
& \text { piped } \\
& \text { not piped }
\end{aligned}
$$

NA

Sanitation

Sew.Sys. \& Sep. Tank 1
Septic Tank 2
Rudimental Cespit
Drain
River or Lake
Other
NA
none
yes
no

Fridge:

$$
\text { yes }
$$$$
\text { no }
$$

Cooker:

$$
\text { yes }
$$$$
\text { no }
$$

Radio:

$$
\text { yes }
$$$$
\text { no }
$$

TV:

$$
\text { yes }
$$$$
\text { no }
$$

198119851988199019931995199719981999

$\begin{array}{llllll}53.8 & 56.9 & 42.2 & 36.8 & 39.1 & 38.2 \\ 53.9 & 51.8 & 39.4 & 36.1 & 34.1 & 34.2 \\ 53.9 & 63.1 & 45.6 & 39.3 & 38.5 & 42.0 \\ 50.3 & 55.8 & 44.1 & 41.4 & 40.7 & 33.0 \\ 54.0 & 47.5 & 37.9 & 34.4 & 31.5 & 30.3\end{array}$

$\begin{array}{lllllllll}31.5 & 41.4 & 32.8 & 40.7 & 49.1 & 34.3 & 33.9 & 32.3 & 33.8\end{array}$

$\begin{array}{lllllllll}65.6 & 69.5 & 65.4 & 76.8 & 63.1 & 50.7 & 50.8 & 49.3 & 51.6\end{array}$

$\begin{array}{lllllllll}65.9 & 70.8 & 63.4 & 76.4 & 61.0 & 46.6 & 48.0 & 49.1 & 49.8\end{array}$

$\begin{array}{lllllllll}56.9 & 64.2 & 53.5 & 61.5 & 64.3 & 46.5 & 44.6 & 43.6 & 46.1\end{array}$

$\begin{array}{lllllllll}28.9 & 43.6 & 41.5 & 47.2 & 57.1 & 52.3 & 49.2 & 39.4 & 47.0\end{array}$

$\begin{array}{lllllllll}6.8 & 17.2 & 16.6 & 26.8 & 30.3 & 17.6 & 23.2 & 21.5 & 22.0\end{array}$

$\begin{array}{lllllllll}5.1 & 2.1 & 0.0 & 6.9 & 8.5 & 5.4 & 4.8 & 2.6 & 0.0\end{array}$

$\begin{array}{lllllll}33.1 & 0.0 & 0.0 & 25.0 & 71.4 & 50.0 & 100.0\end{array}$

$\begin{array}{lllllllll}33.8 & 44.0 & 35.6 & 45.0 & 38.8 & 26.5 & 28.9 & 39.5 & 50.0\end{array}$

$\begin{array}{lllllllll}59.6 & 55.6 & 41.7 & 62.8 & 58.3 & 53.3 & 33.3 & 30.1 & 31.4\end{array}$

$\begin{array}{lllllllll}66.2 & 73.8 & 69.2 & 77.1 & 71.7 & 59.2 & 64.5 & 59.5 & 63.8\end{array}$

$\begin{array}{lllllllll}10.2 & 8.0 & 10.7 & 17.3 & 38.7 & 24.5 & 23.2 & 23.5 & 25.1\end{array}$

$\begin{array}{lllllllll}19.0 & 21.7 & 11.9 & 28.7 & 26.7 & 14.2 & 25.9 & 28.1 & 23.5\end{array}$

$\begin{array}{lllllllll}50.4 & 56.8 & 49.1 & 61.3 & 61.5 & 47.1 & 49.9 & 45.0 & 48.7\end{array}$

$\begin{array}{lllll}50.0 & 88.9 & 80.0 & 73.4 & 83.3\end{array}$

$100.0 \quad 42.9$

$\begin{array}{llllll}45.0 & 49.5 & 12.5 & 60.0 & 100.0 & 100.0\end{array}$

$\begin{array}{llll}71.7 & 76.7 & 74.6 & 82.4\end{array}$

$\begin{array}{lllllllll}38.9 & 46.4 & 39.9 & 52.0 & 52.4 & 38.2 & 38.2 & 37.6 & 38.7\end{array}$

$\begin{array}{lllllllll}68.8 & 77.9 & 74.3 & 83.7 & 73.5 & 67.3 & 71.1 & 50.8 & 60.3\end{array}$

$\begin{array}{lllllllll}21.1 & 26.7 & 18.8 & 32.7 & 38.1 & 25.2 & 29.8 & 29.4 & 31.0\end{array}$

$\begin{array}{lllllllll}63.8 & 73.0 & 69.6 & 77.4 & 71.3 & 59.1 & 64.4 & 57.7 & 62.8\end{array}$

$\begin{array}{lllllllll}45.8 & 53.0 & 45.4 & 54.5 & 53.5 & 40.0 & 39.7 & 38.0 & 39.4\end{array}$

$\begin{array}{lllllllll}65.0 & 70.3 & 75.8 & 78.7 & 68.8 & 51.9 & 43.5 & 46.5 & 52.6\end{array}$

$\begin{array}{lllllll}42.3 & 50.3 & 49.5 & 37.6 & 38.3 & 36.6 & 37.1\end{array}$

$\begin{array}{lllllll}59.8 & 72.1 & 68.2 & 56.9 & 48.5 & 46.8 & 54.8\end{array}$

$\begin{array}{lllllll}24.6 & 37.5 & 44.7 & 33.8 & 37.0 & 37.3 & 36.2\end{array}$

$\begin{array}{lllllll}69.0 & 79.0 & 70.1 & 57.8 & 57.5 & 43.4 & 62.8\end{array}$ 
Appendix C

Rio Grande do Norte

Housing Status:

own, paid

own, still paying

rented

ceded

other

Durable House

yes

no

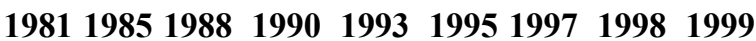

$\begin{array}{lllllllll}55.8 & 59.6 & 52.4 & 63.6 & 57.2 & 41.5 & 43.7 & 40.5 & 40.5\end{array}$

$\begin{array}{lllllllll}15.4 & 19.9 & 12.7 & 19.5 & 30.3 & 23.6 & 14.7 & 15.3 & 18.7\end{array}$

$\begin{array}{lllllllll}29.5 & 44.1 & 32.1 & 40.6 & 41.0 & 24.8 & 27.4 & 27.9 & 32.9\end{array}$

$\begin{array}{lllllllll}63.4 & 73.0 & 67.0 & 72.3 & 69.8 & 61.6 & 45.7 & 49.0 & 55.6\end{array}$

$\begin{array}{lllllllll}40.1 & 16.7 & 25.0 & 40.0 & 50.0 & 33.4 & 49.9 & 11.1 & 100.0\end{array}$

$\begin{array}{lllllllll}43.5 & 53.2 & 44.6 & 54.2 & 52.7 & 39.0 & 38.3 & 36.8 & 38.3\end{array}$

$\begin{array}{lllllll}58.8 & 71.3 & 87.5 & 100.0 & 66.7 & 100.0 & 100.0\end{array}$ 


\section{Table C8: Poverty Profile for Paraíba}

\section{Paraíba}

Total

Gender

male

female

Race

white

black

mulatto

indig

asian

Age:

$<25$

25 to 45

45 to 65

$>65$

Household Characteristics

No. of $<5$

No .of $5 \_15$

No. of $>65$

Location:

urban

rural

Working Class:

carteira

yes

no

active

yes

no

worked

yes

no

Work Sector:

Agri.

Ind.

Service

Social

Public

Other

Work Position:

employee

self-employed

employer $\begin{array}{lllllllll}1981 & 1985 & 1988 & 1990 & 1993 & 1995 & 1997 & 1998 & 1999\end{array}$

$\begin{array}{lllllllll}58.3 & 57.0 & 57.4 & 60.7 & 56.9 & 40.8 & 42.9 & 40.5 & 39.4\end{array}$

$\begin{array}{lllllllll}59.1 & 58.2 & 58.4 & 59.7 & 57.0 & 39.9 & 42.5 & 41.6 & 39.3\end{array}$

$\begin{array}{lllllllll}54.1 & 51.4 & 53.4 & 63.6 & 56.4 & 43.4 & 43.9 & 37.2 & 39.7\end{array}$

$$
\begin{array}{ccccccc}
51.0 & 53.4 & 44.5 & 32.3 & 35.1 & 32.0 & 30.9 \\
61.9 & 73.6 & 58.5 & 56.4 & 56.2 & 54.2 & 45.2 \\
63.2 & 64.9 & 63.9 & 44.4 & 48.1 & 46.0 & 47.3 \\
& & & & & & \\
& 100.0 & & 0.0 & & & 0.0
\end{array}
$$

$\begin{array}{lllllllll}49.1 & 59.0 & 54.8 & 68.6 & 81.2 & 64.5 & 65.3 & 60.5 & 63.2\end{array}$ $\begin{array}{lllllllll}60.9 & 60.5 & 60.3 & 60.6 & 64.7 & 49.5 & 49.1 & 47.1 & 45.5\end{array}$ $\begin{array}{lllllllll}60.7 & 59.6 & 59.8 & 58.8 & 57.0 & 37.1 & 37.7 & 39.7 & 37.3\end{array}$ $\begin{array}{lllllllll}50.5 & 43.2 & 48.1 & 60.9 & 25.5 & 18.2 & 25.7 & 15.2 & 19.9\end{array}$

$\begin{array}{lllllllll}59.6 & 61.2 & 67.7 & 65.6 & 69.5 & 60.5 & 69.6 & 53.3 & 55.0\end{array}$ $\begin{array}{llllllllll}58.8 & 57.5 & 61.0 & 61.9 & 60.3 & 42.9 & 47.4 & 42.8 & 44.6\end{array}$ $\begin{array}{lllllllll}45.5 & 49.1 & 50.9 & 61.8 & 36.9 & 25.4 & 29.0 & 19.2 & 27.0\end{array}$

$\begin{array}{lllllllll}44.0 & 44.9 & 45.7 & 50.3 & 48.1 & 30.9 & 34.7 & 31.8 & 29.8\end{array}$

$\begin{array}{lllllllll}82.8 & 79.4 & 80.3 & 83.5 & 75.4 & 61.9 & 63.0 & 59.8 & 62.0\end{array}$

$\begin{array}{lllllllll}34.6 & 34.8 & 38.1 & 47.7 & 44.3 & 34.5 & 29.2 & 25.6 & 26.8\end{array}$ $\begin{array}{lllllllll}79.5 & 75.6 & 73.7 & 75.5 & 84.2 & 64.3 & 60.5 & 60.8 & 63.1\end{array}$

$\begin{array}{llllll}59.9 & 58.9 & 43.0 & 44.0 & 42.6 & 41.2\end{array}$ $\begin{array}{llllll}63.0 & 49.7 & 33.5 & 38.9 & 33.6 & 33.6\end{array}$

$\begin{array}{lllllllll}59.4 & 59.3 & 58.9 & 59.8 & 57.6 & 42.1 & 41.9 & 41.7 & 40.0\end{array}$ $\begin{array}{lllllllll}55.3 & 50.0 & 52.7 & 62.9 & 55.1 & 37.2 & 45.5 & 37.2 & 38.0\end{array}$

$\begin{array}{lllllllll}75.6 & 81.8 & 81.9 & 82.7 & 73.5 & 62.7 & 64.6 & 64.6 & 59.6\end{array}$ $\begin{array}{llllllllll}69.2 & 56.8 & 59.0 & 62.2 & 60.4 & 40.1 & 34.5 & 43.5 & 52.9\end{array}$ $\begin{array}{lllllllll}39.5 & 37.1 & 42.1 & 43.6 & 46.3 & 26.8 & 30.4 & 25.4 & 26.8\end{array}$ $\begin{array}{lllllllll}28.7 & 28.4 & 31.4 & 43.5 & 29.3 & 25.8 & 17.9 & 24.2 & 14.0\end{array}$ $\begin{array}{lllllllll}32.9 & 33.6 & 31.2 & 39.6 & 51.4 & 19.0 & 20.0 & 21.5 & 12.6\end{array}$ $\begin{array}{lllllllll}15.0 & 11.8 & 42.8 & 21.7 & 7.1 & 0.0 & 10.0 & 0.0 & 4.5\end{array}$

$\begin{array}{lllllllll}61.3 & 61.1 & 59.5 & 63.8 & 61.1 & 45.7 & 41.4 & 40.2 & 41.0\end{array}$ $\begin{array}{rrrrrrrrr}56.6 & 59.5 & 60.7 & 59.1 & 57.7 & 42.0 & 47.0 & 46.5 & 42.7\end{array}$ $\begin{array}{lllllllll}20.0 & 26.1 & 41.2 & 27.0 & 19.1 & 10.5 & 10.2 & 3.8 & 0.0\end{array}$ 
Paraíba

Tenure

$<1$

$>1$

1 to 3

3 to 5

$>5$

Education

Read and Write

yes

no

Years of Schooling:

no education or $<1$

1 to 4

4 to 8

8 to 12

more than 12

NA

Waste Disposal

collected

burnt

dumped on unused land, river, sea other

Water Supply

piped

not piped

NA

Sanitation

Sew.Sys. \& Sep. Tank 1

Septic Tank 2

Rudimental Cespit

Drain

River or Lake

Other

NA

none

Electricity

yes

no

Fridge:

yes

no

Cooker:

yes

no

Radio:

yes

no

TV:

yes

no

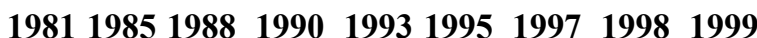

$\begin{array}{llllll}59.5 & 57.9 & 42.5 & 42.2 & 41.6 & 39.8 \\ 57.6 & 53.6 & 40.8 & 41.5 & 40.1 & 38.7 \\ 61.2 & 50.3 & 44.8 & 47.6 & 42.0 & 47.8 \\ 58.5 & 55.6 & 43.2 & 48.4 & 38.8 & 39.1 \\ 56.7 & 53.8 & 39.3 & 39.6 & 39.5 & 35.4\end{array}$

$\begin{array}{lllllllll}41.1 & 40.2 & 44.5 & 44.9 & 48.5 & 32.4 & 33.6 & 31.3 & 31.2\end{array}$

$\begin{array}{lllllllll}72.4 & 73.8 & 72.2 & 79.0 & 69.3 & 52.6 & 58.8 & 56.3 & 53.8\end{array}$

$\begin{array}{lllllllll}71.4 & 73.9 & 71.4 & 78.9 & 67.2 & 51.0 & 54.6 & 55.2 & 51.3\end{array}$

$\begin{array}{lllllllll}66.4 & 61.9 & 65.6 & 66.9 & 63.0 & 44.7 & 51.2 & 45.7 & 49.5\end{array}$

$\begin{array}{lllllllll}38.5 & 38.2 & 47.4 & 49.7 & 65.0 & 36.4 & 36.1 & 35.7 & 39.9\end{array}$

$\begin{array}{llllllllll}14.1 & 15.4 & 25.1 & 29.4 & 36.7 & 19.3 & 24.3 & 19.8 & 19.5\end{array}$

$\begin{array}{lllllllll}4.6 & 4.1 & 5.4 & 4.2 & 10.7 & 2.1 & 4.0 & 3.4 & 2.7\end{array}$

$\begin{array}{lllllll}100.0 & 16.5 & 0.0 & 25.0 & 0.0 & 100.0 & 75.0\end{array}$

$\begin{array}{lllllllll}38.9 & 38.6 & 38.7 & 45.4 & 44.1 & 27.3 & 32.9 & 30.3 & 30.0\end{array}$

$\begin{array}{llllllllll}72.6 & 78.9 & 63.6 & 68.1 & 75.6 & 48.7 & 61.5 & 56.6 & 55.4\end{array}$

$\begin{array}{lllllllll}67.7 & 72.3 & 75.3 & 79.7 & 75.6 & 61.2 & 63.8 & 62.7 & 64.5\end{array}$

$\begin{array}{lllllllll}33.0 & 33.3 & 0.0 & 50.1 & 54.5 & 70.0 & 54.3 & 0.0 & 69.4\end{array}$

$\begin{array}{lllllllll}40.2 & 40.9 & 44.5 & 49.6 & 45.7 & 28.5 & 32.7 & 31.6 & 34.0\end{array}$

$\begin{array}{lllllllll}65.5 & 82.1 & 79.6 & 85.1 & 50.0 & 50.0 & 55.5 & 30.1 & 28.7\end{array}$

$\begin{array}{lllllllll}79.0 & 78.5 & 77.6 & 83.4 & 76.5 & 63.1 & 63.7 & 64.1 & 64.2\end{array}$

$\begin{array}{lllllllll}17.4 & 18.0 & 22.0 & 30.0 & 31.6 & 24.4 & 26.4 & 20.4 & 20.5\end{array}$

$\begin{array}{lllllllll}27.0 & 27.5 & 37.8 & 32.9 & 45.1 & 24.1 & 22.5 & 21.0 & 22.4\end{array}$

$\begin{array}{lllllllll}53.6 & 58.9 & 56.5 & 68.5 & 59.5 & 42.9 & 49.5 & 44.3 & 46.5\end{array}$

$\begin{array}{lllll}70.8 & 59.0 & 50.0 & 59.3 & 67.9\end{array}$

$\begin{array}{lllll}47.4 & 29.4 & 40.0 & 62.5 & 42.9\end{array}$

$\begin{array}{llllllll}50.0 & 36.4 & 44.4 & 62.3 & 0.0 & 0.0 & 0.0 & 100.0\end{array}$

$\begin{array}{llll}82.8 & 83.1 & 81.2 & 85.8\end{array}$

$\begin{array}{lllllllll}41.8 & 44.1 & 48.8 & 52.8 & 52.5 & 37.5 & 42.1 & 39.2 & 38.5\end{array}$ $\begin{array}{lllllllll}80.0 & 81.4 & 80.6 & 89.7 & 77.3 & 67.3 & 58.3 & 68.7 & 66.2\end{array}$

$\begin{array}{lllllllll}22.5 & 23.1 & 30.3 & 32.2 & 37.2 & 22.7 & 29.3 & 28.7 & 27.2\end{array}$

$\begin{array}{lllllllll}72.5 & 72.5 & 73.3 & 80.7 & 74.0 & 58.7 & 65.5 & 63.4 & 66.4\end{array}$

$\begin{array}{lllllllll}58.0 & 56.7 & 57.5 & 59.0 & 56.6 & 40.8 & 42.8 & 40.2 & 39.3\end{array}$ $\begin{array}{llllllllll}60.9 & 65.4 & 57.8 & 85.5 & 75.0 & 32.3 & 47.6 & 62.5 & 57.1\end{array}$

$\begin{array}{lllllll}54.6 & 56.2 & 53.7 & 38.7 & 41.3 & 39.1 & 38.6\end{array}$ $\begin{array}{llllllll}65.3 & 73.8 & 69.7 & 53.2 & 55.9 & 51.8 & 45.9\end{array}$

$\begin{array}{lllllll}41.1 & 41.8 & 46.4 & 33.7 & 41.0 & 37.9 & 36.9\end{array}$

$\begin{array}{llllllll}73.4 & 83.4 & 72.5 & 58.5 & 54.1 & 56.7 & 57.8\end{array}$ 
Appendix C

Paraíba

Housing Status:

own, paid

own, still paying

rented

ceded

other

Durable House

yes

no
198119851988199019931995199719981999

$\begin{array}{rrrrrrrrr}62.4 & 61.3 & 62.9 & 63.1 & 58.0 & 41.4 & 42.8 & 41.7 & 39.0 \\ 11.5 & 15.7 & 21.9 & 23.6 & 30.6 & 12.3 & 21.1 & 14.5 & 18.8 \\ 38.2 & 41.1 & 40.2 & 52.6 & 48.1 & 25.2 & 32.5 & 26.9 & 23.6 \\ 81.2 & 79.2 & 74.7 & 75.5 & 69.2 & 56.8 & 58.7 & 55.8 & 66.1 \\ 66.6 & 14.2 & 33.3 & 50.1 & 77.8 & 60.0 & 25.0 & 20.0 & 44.4 \\ & & & & & & & & \\ 55.9 & 54.0 & 55.7 & 59.0 & 55.4 & 39.4 & 41.8 & 39.7 & 38.7 \\ 85.8 & 90.9 & 71.4 & 100.0 & 100.0 & 100.0 & & \end{array}$




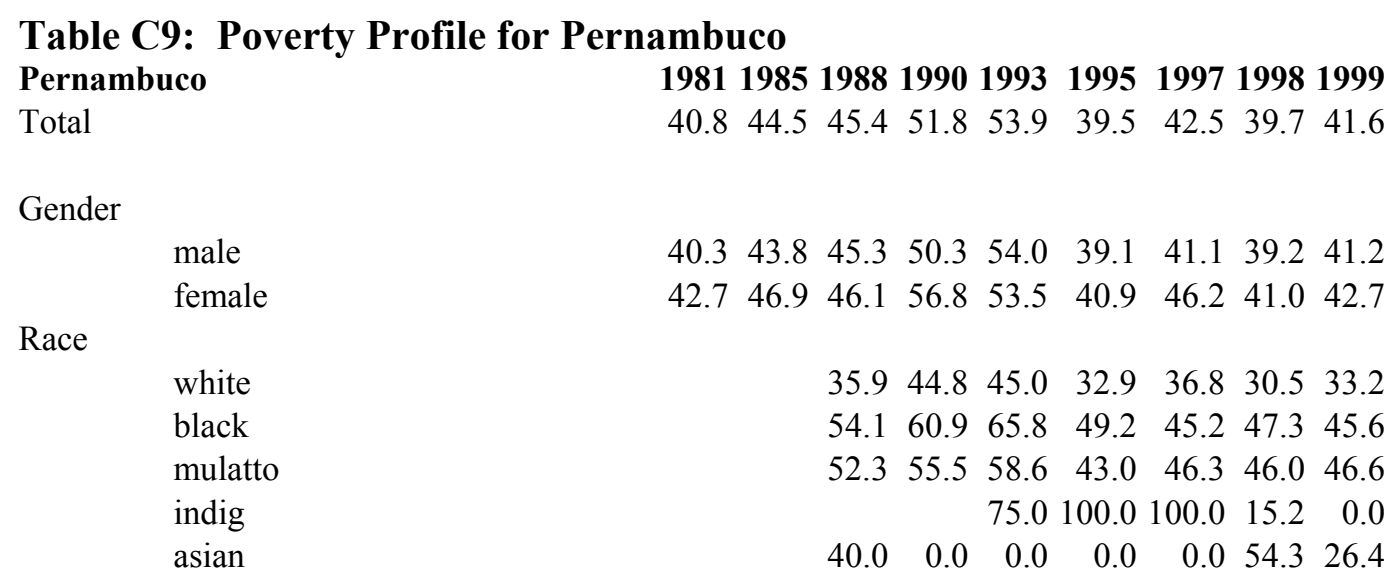

Age:

$<25$

25 to 45

45 to 65

$>65$

$\begin{array}{lllllllll}37.2 & 47.2 & 50.2 & 52.4 & 71.7 & 58.5 & 60.5 & 61.1 & 64.1\end{array}$

$\begin{array}{lllllllll}45.0 & 48.4 & 48.1 & 53.5 & 59.7 & 45.3 & 48.0 & 45.6 & 48.4\end{array}$

$\begin{array}{llllllllll}38.6 & 41.8 & 42.3 & 47.3 & 50.5 & 36.3 & 35.6 & 34.2 & 34.7\end{array}$

$\begin{array}{lllllllll}34.2 & 37.0 & 41.2 & 56.3 & 30.6 & 17.2 & 26.5 & 19.2 & 20.2\end{array}$

Household Characteristics

$\begin{array}{lllllllll}46.8 & 52.4 & 51.9 & 59.7 & 68.2 & 56.6 & 62.3 & 56.9 & 60.8\end{array}$

No. of $<5$

No .of $5 \_15$

No.of $>65$

$\begin{array}{lllllllll}40.5 & 45.8 & 47.6 & 51.1 & 62.4 & 42.1 & 50.4 & 42.6 & 48.1\end{array}$

$\begin{array}{lllllllll}33.2 & 36.7 & 41.6 & 51.8 & 33.7 & 21.7 & 28.3 & 22.2 & 24.8\end{array}$

Location:

urban

$\begin{array}{lllllllll}34.3 & 38.3 & 39.5 & 46.1 & 49.5 & 34.6 & 37.7 & 35.5 & 38.2\end{array}$

rural

$\begin{array}{lllllllll}54.3 & 58.2 & 60.5 & 67.3 & 70.3 & 57.3 & 60.9 & 55.8 & 55.7\end{array}$

Working Class:

carteira

yes

$\begin{array}{lllllllll}27.9 & 29.6 & 32.0 & 46.6 & 45.9 & 33.5 & 32.6 & 31.4 & 30.6\end{array}$

no

$\begin{array}{lllllllll}54.5 & 57.6 & 59.7 & 61.2 & 76.4 & 53.4 & 56.0 & 55.0 & 55.8\end{array}$

active

yes

$\begin{array}{llllll}49.3 & 55.9 & 40.5 & 42.9 & 40.0 & 42.7\end{array}$

no

$\begin{array}{llllll}60.1 & 46.9 & 36.2 & 41.2 & 39.0 & 38.3\end{array}$

worked

yes

$\begin{array}{lllllllll}40.1 & 44.4 & 44.7 & 49.1 & 54.1 & 39.0 & 40.5 & 37.8 & 40.1\end{array}$

no

$\begin{array}{lllllllll}43.1 & 44.5 & 48.0 & 59.8 & 53.3 & 41.0 & 47.3 & 43.9 & 45.0\end{array}$

Work Sector:

Agri.

$\begin{array}{lllllllll}53.9 & 63.9 & 67.5 & 73.5 & 71.8 & 57.6 & 64.7 & 57.9 & 58.7\end{array}$

Ind.

Service

Social

Public

Other

Work Position:

employee

$\begin{array}{llllllllll}37.1 & 34.7 & 39.0 & 48.3 & 58.0 & 34.8 & 37.9 & 42.8 & 43.9\end{array}$

$\begin{array}{llllllllll}32.6 & 35.4 & 36.6 & 40.3 & 47.4 & 31.3 & 32.3 & 29.6 & 33.7\end{array}$

$\begin{array}{lllllllll}29.5 & 25.3 & 19.4 & 27.4 & 31.7 & 24.4 & 16.5 & 17.8 & 16.1\end{array}$

$\begin{array}{llllllllll}20.5 & 25.3 & 29.6 & 33.4 & 33.7 & 22.9 & 16.3 & 18.6 & 17.8\end{array}$

$\begin{array}{lllllllll}17.3 & 41.3 & 30.0 & 20.3 & 37.4 & 36.2 & 34.4 & 36.5 & 47.1\end{array}$

self-employed

$\begin{array}{lllllllll}39.0 & 42.0 & 43.3 & 52.9 & 55.2 & 39.0 & 39.1 & 38.0 & 39.4\end{array}$

employer

$\begin{array}{llllllllll}46.7 & 52.5 & 50.5 & 48.2 & 55.8 & 41.3 & 44.6 & 41.4 & 44.7\end{array}$

$\begin{array}{lllllllll}6.4 & 15.5 & 13.7 & 12.5 & 14.5 & 8.1 & 10.5 & 9.6 & 8.7\end{array}$ 
Pernambuco

Tenure
$<1$
$>1$
1 to 3
3 to 5
$>5$

Education

Read and Write

yes

no

Years of Schooling:

no education or $<1$

1 to 4

4 to 8

8 to 12

more than 12

NA

Waste Disposal

collected

burnt

dumped on unused land, river, sea

other

Water Supply

piped

not piped

NA

Sanitation

Sew.Sys. \& Sep. Tank 1

Septic Tank 2

Rudimental Cespit

Drain

River or Lake

Other

NA

none

Electricity

yes

no

Fridge:

yes

no

Cooker:

yes

no

Radio:

yes

no

TV:

yes

no
198119851988199019931995199719981999

$\begin{array}{llllll}49.2 & 54.1 & 38.9 & 40.8 & 38.0 & 40.2 \\ 49.8 & 50.1 & 37.1 & 39.6 & 35.2 & 38.3 \\ 49.7 & 57.1 & 41.3 & 41.7 & 37.7 & 45.0 \\ 45.4 & 49.6 & 35.3 & 39.6 & 32.5 & 38.8 \\ 50.3 & 47.2 & 35.3 & 38.8 & 34.8 & 35.7\end{array}$

$\begin{array}{lllllllll}30.4 & 33.1 & 33.2 & 40.0 & 47.1 & 32.0 & 35.5 & 34.2 & 36.5\end{array}$

$\begin{array}{lllllllll}52.6 & 58.2 & 64.2 & 68.7 & 66.7 & 52.0 & 57.5 & 52.3 & 53.0\end{array}$

$\begin{array}{lllllllll}52.2 & 58.4 & 63.1 & 68.9 & 64.5 & 49.7 & 55.4 & 49.9 & 50.2\end{array}$

$\begin{array}{lllllllll}47.0 & 49.2 & 51.1 & 59.7 & 61.9 & 44.4 & 46.6 & 46.1 & 51.0\end{array}$

$\begin{array}{lllllllll}29.8 & 33.8 & 36.9 & 45.6 & 53.9 & 40.4 & 48.3 & 42.8 & 45.8\end{array}$

$\begin{array}{lllllllll}10.4 & 13.8 & 11.6 & 21.1 & 30.8 & 16.8 & 22.4 & 22.4 & 22.5\end{array}$

$\begin{array}{lllllllll}0.4 & 0.7 & 2.4 & 2.1 & 4.0 & 4.3 & 4.0 & 2.7 & 2.3\end{array}$

$\begin{array}{llllllll}20.7 & 58.8 & 45.8 & 53.2 & 55.4 & 57.7 & 25.0 & 29.6\end{array}$

$\begin{array}{lllllllll}23.4 & 28.2 & 29.2 & 36.7 & 43.7 & 29.9 & 34.4 & 32.7 & 35.8\end{array}$

$\begin{array}{llllllllll}43.0 & 49.3 & 62.7 & 63.1 & 67.3 & 54.8 & 56.6 & 54.3 & 55.6\end{array}$

$\begin{array}{llllllllll}47.5 & 49.9 & 58.9 & 69.6 & 70.0 & 55.3 & 62.4 & 57.9 & 57.9\end{array}$

$\begin{array}{lllllllll}20.8 & 9.1 & 0.0 & 35.9 & 53.6 & 38.0 & 64.9 & 46.9 & 58.7\end{array}$

$\begin{array}{lllllllll}26.9 & 31.6 & 33.4 & 41.2 & 44.3 & 29.7 & 33.9 & 40.9 & 38.0\end{array}$

$\begin{array}{lllllllll}43.0 & 49.6 & 57.5 & 66.5 & 33.0 & 34.3 & 32.5 & 32.4 & 34.5\end{array}$

$\begin{array}{lllllllll}57.6 & 63.8 & 68.3 & 76.3 & 71.3 & 57.5 & 62.4 & 57.8 & 59.0\end{array}$

$\begin{array}{lllllllll}9.0 & 11.9 & 12.8 & 25.5 & 32.6 & 20.6 & 24.1 & 24.5 & 26.5\end{array}$

$\begin{array}{lllllllll}11.6 & 23.0 & 17.0 & 10.0 & 42.7 & 21.1 & 30.8 & 29.9 & 29.3\end{array}$

$\begin{array}{lllllllll}37.6 & 41.8 & 44.8 & 54.7 & 56.5 & 42.3 & 48.0 & 42.4 & 44.2\end{array}$

$\begin{array}{lllll}69.1 & 59.8 & 62.5 & 53.0 & 51.9\end{array}$

$\begin{array}{lllll}60.1 & 39.6 & 41.1 & 38.3 & 49.5\end{array}$

$\begin{array}{lllllllll}36.0 & 38.7 & 35.1 & 47.6 & 86.1 & 33.3 & 55.0 & 67.8 & 53.1\end{array}$ 27.0

$\begin{array}{llll}58.5 & 66.1 & 72.1 & 79.4\end{array}$

$\begin{array}{lllllllll}31.1 & 35.6 & 38.7 & 46.5 & 50.7 & 37.2 & 40.8 & 38.2 & 40.5\end{array}$

$\begin{array}{lllllllll}59.0 & 66.5 & 71.7 & 77.7 & 75.2 & 60.0 & 63.9 & 66.9 & 64.2\end{array}$

$\begin{array}{lllllllll}17.9 & 22.6 & 23.3 & 29.3 & 36.6 & 25.3 & 31.6 & 30.8 & 32.3\end{array}$

$\begin{array}{lllllllll}53.4 & 59.0 & 64.5 & 72.6 & 72.0 & 56.7 & 64.0 & 58.8 & 62.5\end{array}$

$\begin{array}{lllllllll}39.9 & 43.6 & 44.9 & 51.3 & 53.4 & 39.5 & 42.6 & 39.8 & 41.6\end{array}$

$\begin{array}{lllllllll}51.3 & 59.3 & 62.0 & 65.5 & 71.7 & 37.8 & 35.2 & 37.2 & 43.3\end{array}$

$\begin{array}{lllllll}40.9 & 45.9 & 49.6 & 37.7 & 40.8 & 38.5 & 39.9\end{array}$ $\begin{array}{lllllll}57.6 & 70.4 & 69.3 & 50.3 & 58.0 & 50.1 & 56.7\end{array}$

$\begin{array}{lllllll}30.7 & 35.9 & 43.9 & 32.8 & 39.4 & 37.1 & 39.0\end{array}$ $\begin{array}{lllllll}63.9 & 73.4 & 70.3 & 55.8 & 57.1 & 54.1 & 56.6\end{array}$ 
Pernambuco

Housing Status:

own, paid

own, still paying

rented

ceded

other

Durable House

yes

no
198119851988199019931995199719981999

$\begin{array}{lllllllll}44.9 & 48.5 & 48.6 & 53.6 & 54.4 & 40.6 & 43.6 & 41.5 & 42.6\end{array}$

$\begin{array}{lllllllll}18.2 & 14.9 & 13.3 & 20.7 & 34.1 & 19.8 & 19.2 & 18.7 & 13.6\end{array}$

$\begin{array}{lllllllll}30.9 & 34.1 & 37.4 & 43.1 & 48.8 & 29.9 & 34.7 & 27.2 & 32.7\end{array}$

$\begin{array}{lllllllll}46.5 & 53.2 & 56.9 & 67.1 & 65.7 & 52.4 & 54.8 & 53.5 & 55.2\end{array}$

$\begin{array}{lllllllll}36.2 & 32.0 & 28.9 & 59.5 & 69.8 & 42.3 & 49.0 & 28.9 & 25.0\end{array}$

$\begin{array}{lllllllll}38.2 & 42.3 & 43.1 & 49.4 & 52.2 & 38.3 & 41.5 & 38.5 & 40.7\end{array}$

$\begin{array}{lllllllll}53.4 & 55.7 & 85.1 & 66.7 & 81.5 & 50.0 & 66.2 & 69.3 & 54.7\end{array}$ 


\section{Table C10: Poverty Profile for Alagoas}

\begin{tabular}{|c|c|c|c|c|c|c|c|c|c|c|}
\hline Alagoas & & 1981 & 1985 & 1988 & 1990 & 1993 & 1995 & 1997 & 1998 & 1999 \\
\hline Total & & 42.8 & 45.7 & 49.5 & 59.7 & 58.5 & 46.2 & 45.9 & 44.1 & 47.2 \\
\hline \multicolumn{11}{|l|}{ Gender } \\
\hline & male & 43.8 & 46.9 & 50.7 & 59.0 & 59.6 & 46.0 & 44.9 & 42.9 & 47.4 \\
\hline & female & 38.1 & 40.3 & 44.4 & 62.4 & 54.8 & 46.9 & 48.4 & 47.6 & 46.8 \\
\hline \multicolumn{11}{|l|}{ Race } \\
\hline & white & & & 39.2 & 50.0 & 45.9 & 37.2 & 39.8 & 35.2 & 37.7 \\
\hline & black & & & 66.7 & 61.3 & 58.7 & 49.3 & 52.5 & 51.2 & 53.9 \\
\hline & mulatto & & & 53.1 & 64.4 & 66.8 & 51.8 & 49.5 & 49.3 & 53.8 \\
\hline & indig & & & & & & & & & \\
\hline & asian & & & & & 100.0 & & 0.0 & & 0.0 \\
\hline \multicolumn{11}{|l|}{ Age: } \\
\hline & $<25$ & 29.6 & 45.9 & 46.2 & 65.7 & 76.1 & 67.8 & 64.2 & 62.0 & 72.7 \\
\hline & 25 to 45 & 45.0 & 51.1 & 54.7 & 59.4 & 64.3 & 52.2 & 46.6 & 48.9 & 52.9 \\
\hline & 45 to 65 & 44.1 & 43.8 & 46.8 & 58.2 & 56.6 & 40.9 & 45.4 & 42.4 & 44.1 \\
\hline & $>65$ & 40.1 & 32.5 & 41.5 & 60.8 & 31.4 & 23.7 & 28.9 & 21.4 & 20.2 \\
\hline \multicolumn{11}{|c|}{ Household Characteristics } \\
\hline & No. of $<5$ & 49.3 & 53.5 & 59.0 & 67.9 & 70.5 & 59.1 & 63.2 & 52.8 & 61.7 \\
\hline & No .of 5_15 & 46.5 & 44.3 & 51.9 & 59.8 & 60.6 & 46.3 & 53.2 & 50.0 & 47.9 \\
\hline & No.of $>\overline{65}$ & 41.6 & 35.6 & 44.4 & 63.9 & 36.8 & 28.6 & 32.3 & 26.2 & 26.7 \\
\hline \multicolumn{11}{|c|}{ Location: } \\
\hline & urban & 36.0 & 42.4 & 44.7 & 50.6 & 50.3 & 40.3 & 39.1 & 39.3 & 41.5 \\
\hline & rural & 50.3 & 50.1 & 56.7 & 73.4 & 73.8 & 58.2 & 60.0 & 54.3 & 59.3 \\
\hline \multicolumn{11}{|c|}{$\begin{array}{l}\text { Working Class: } \\
\text { carteira }\end{array}$} \\
\hline & yes & 24.1 & 32.0 & 41.2 & 51.1 & 54.9 & 40.6 & 36.5 & 39.8 & 42.9 \\
\hline & no & 53.1 & 57.7 & 68.5 & 76.0 & 82.9 & 64.4 & 61.2 & 60.3 & 70.1 \\
\hline & active & & & & & & & & & \\
\hline & yes & & & & 59.1 & 60.9 & 48.0 & 44.2 & 44.9 & 50.1 \\
\hline & no & & & & 62.2 & 50.0 & 41.0 & 50.4 & 41.5 & 38.7 \\
\hline & worked & & & & & & & & & \\
\hline & yes & 42.3 & 46.6 & 50.1 & 59.2 & 59.7 & 46.2 & 41.9 & 42.7 & 46.6 \\
\hline & no & 44.3 & 42.0 & 47.2 & 61.5 & 55.4 & 46.4 & 54.7 & 47.2 & 48.6 \\
\hline \multicolumn{11}{|c|}{ Work Sector: } \\
\hline & Agri. & 53.2 & 58.6 & 65.3 & 77.0 & 77.2 & 65.9 & 65.3 & 62.2 & 69.6 \\
\hline & Ind. & 35.9 & 33.2 & 45.4 & 56.9 & 56.5 & 47.3 & 40.0 & 37.9 & 45.0 \\
\hline & Service & 28.4 & 35.7 & 38.6 & 40.1 & 51.1 & 29.0 & 29.8 & 32.6 & 34.9 \\
\hline & Social & 13.0 & 19.6 & 30.0 & 35.0 & 18.8 & 36.6 & 24.1 & 21.3 & 19.6 \\
\hline & Public & 26.2 & 35.3 & 30.4 & 40.8 & 46.8 & 30.3 & 25.4 & 26.0 & 23.6 \\
\hline & Other & 0.0 & 23.8 & 16.6 & 8.3 & 30.0 & 0.0 & 0.0 & 0.0 & 0.0 \\
\hline \multicolumn{11}{|c|}{ Work Position: } \\
\hline & employee & 39.4 & 46.1 & 52.9 & 62.8 & 62.0 & 47.3 & 42.3 & 45.4 & 51.4 \\
\hline & self-employed & 48.7 & 49.4 & 49.3 & 56.0 & 58.3 & 48.4 & 42.4 & 41.5 & 40.5 \\
\hline & employer & 12.5 & 7.1 & 6.7 & 12.8 & 23.1 & 0.0 & 0.0 & 6.1 & 16.0 \\
\hline
\end{tabular}


Alagoas

Tenure

$<1$

$>1$

1 to 3

3 to 5

$>5$

Education

Read and Write

yes

no

Years of Schooling:

no education or $<1$

1 to 4

4 to 8

8 to 12

more than 12

NA

Waste Disposal

collected

burnt

dumped on unused land, river, sea other

Water Supply

piped

not piped

NA

Sanitation

Sew.Sys. \& Sep. Tank 1

Septic Tank 2

Rudimental Cespit

Drain

River or Lake

Other

NA

none

Electricity

yes

no

Fridge:

yes

no

Cooker:

$$
\text { yes }
$$

no

Radio:

yes

no

TV:

yes

no
198119851988199019931995199719981999

$\begin{array}{llllll}58.7 & 59.4 & 46.4 & 42.0 & 42.8 & 46.6 \\ 58.9 & 57.8 & 44.3 & 42.2 & 41.7 & 45.4 \\ 55.9 & 71.6 & 55.4 & 43.2 & 43.1 & 48.8 \\ 52.8 & 60.6 & 45.2 & 39.6 & 46.6 & 50.4 \\ 59.6 & 52.2 & 40.1 & 41.5 & 40.2 & 43.3\end{array}$

$\begin{array}{lllllllll}31.6 & 35.0 & 36.2 & 44.8 & 49.4 & 37.1 & 35.4 & 35.5 & 38.0\end{array}$

$\begin{array}{lllllllll}51.9 & 53.3 & 61.7 & 74.5 & 73.0 & 60.0 & 60.1 & 56.6 & 60.8\end{array}$

$\begin{array}{lllllllll}52.2 & 53.8 & 60.6 & 74.2 & 71.7 & 60.2 & 57.7 & 57.1 & 60.9\end{array}$

$\begin{array}{lllllllll}40.1 & 49.6 & 57.1 & 60.8 & 61.7 & 48.1 & 52.9 & 49.5 & 51.5\end{array}$

$\begin{array}{lllllllll}33.1 & 30.9 & 35.9 & 50.7 & 69.4 & 52.3 & 55.8 & 46.4 & 56.6\end{array}$

$\begin{array}{lllllllll}5.1 & 12.2 & 12.5 & 29.0 & 30.8 & 18.2 & 22.1 & 21.2 & 18.5\end{array}$

$\begin{array}{lllllllll}2.4 & 3.1 & 0.0 & 2.0 & 4.6 & 6.3 & 6.2 & 4.2 & 8.1\end{array}$

$\begin{array}{rrrrrr}50.0 & 0.0 & 0.0 & 0.0 & 100.0\end{array}$

$\begin{array}{lllllllll}27.3 & 35.6 & 38.9 & 44.5 & 46.2 & 37.2 & 39.1 & 37.6 & 41.7\end{array}$

$\begin{array}{llllllllll}29.4 & 50.0 & 56.3 & 73.3 & 78.4 & 61.3 & 65.6 & 55.4 & 56.5\end{array}$

$\begin{array}{lllllllll}51.5 & 52.2 & 57.7 & 72.9 & 76.2 & 62.3 & 60.2 & 62.0 & 66.1\end{array}$

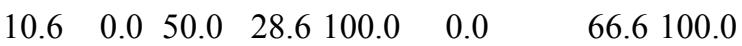

$\begin{array}{lllllllll}28.2 & 35.0 & 37.5 & 43.9 & 45.3 & 36.8 & 36.6 & 28.6 & 26.9\end{array}$

$\begin{array}{llllllllll}48.4 & 59.5 & 53.6 & 73.2 & 48.4 & 34.6 & 37.0 & 35.8 & 40.3\end{array}$

$\begin{array}{lllllllll}51.4 & 46.7 & 63.0 & 77.8 & 78.5 & 61.6 & 64.2 & 63.4 & 67.3\end{array}$

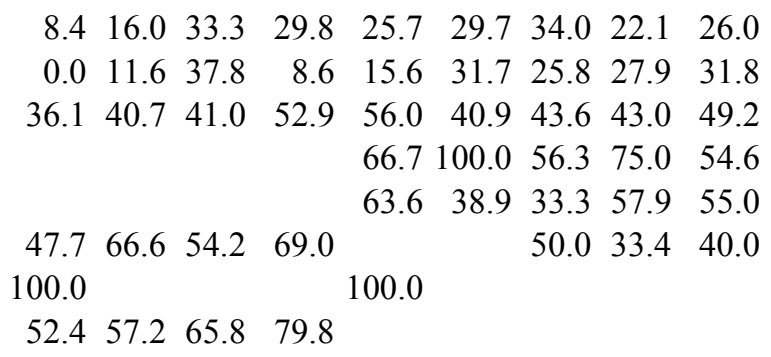

$\begin{array}{lllllllll}32.1 & 40.4 & 44.3 & 53.5 & 56.0 & 44.0 & 44.0 & 42.3 & 45.5\end{array}$ $\begin{array}{lllllllll}56.3 & 55.9 & 63.5 & 79.5 & 74.5 & 61.7 & 60.6 & 62.7 & 64.6\end{array}$

$\begin{array}{lllllllll}19.4 & 24.6 & 32.6 & 40.6 & 40.8 & 31.5 & 35.1 & 32.7 & 36.1\end{array}$ $\begin{array}{lllllllll}52.1 & 56.7 & 62.4 & 75.2 & 78.5 & 64.6 & 63.1 & 63.7 & 69.5\end{array}$

$\begin{array}{lllllllll}39.0 & 42.2 & 48.0 & 57.1 & 57.7 & 46.0 & 45.8 & 44.0 & 46.9\end{array}$ $\begin{array}{lllllllll}54.5 & 59.8 & 71.6 & 78.5 & 76.0 & 60.9 & 53.9 & 50.0 & 65.0\end{array}$

$\begin{array}{lllllll}44.0 & 51.7 & 51.6 & 41.7 & 42.8 & 42.3 & 44.1\end{array}$ $\begin{array}{lllllll}57.6 & 74.5 & 75.0 & 64.6 & 61.3 & 52.0 & 61.4\end{array}$

$\begin{array}{lllllll}33.5 & 43.5 & 46.1 & 39.2 & 42.1 & 40.2 & 44.0\end{array}$ $\begin{array}{lllllll}63.6 & 75.4 & 78.1 & 60.7 & 59.3 & 60.6 & 61.6\end{array}$ 
Appendix C

\section{Alagoas}

Housing Status:

own, paid

own, still paying

rented

ceded

other

Durable House

yes

no
198119851988199019931995199719981999

$\begin{array}{lllllllll}47.9 & 49.1 & 54.3 & 60.0 & 56.8 & 45.6 & 46.6 & 44.1 & 46.6\end{array}$

$\begin{array}{lllllllll}17.7 & 20.6 & 4.6 & 25.5 & 31.1 & 10.6 & 24.2 & 11.4 & 11.3\end{array}$

$\begin{array}{lllllllll}33.3 & 34.1 & 35.5 & 46.8 & 52.5 & 42.5 & 31.3 & 38.9 & 43.5\end{array}$

$\begin{array}{lllllllll}41.1 & 47.2 & 53.4 & 72.7 & 74.0 & 58.8 & 60.3 & 58.9 & 63.5\end{array}$

$\begin{array}{llllllll}21.5 & 18.2 & 40.0 & 25.0 & 100.0 & 57.2 & 33.3 & 50.0\end{array}$

$\begin{array}{lllllllll}38.9 & 42.0 & 46.6 & 56.6 & 55.8 & 43.0 & 44.6 & 41.9 & 46.0\end{array}$

$\begin{array}{lllllllll}48.5 & 70.0 & 44.5 & 100.0 & 86.4 & 64.3 & 60.0 & 66.7 & 66.7\end{array}$ 


\section{Table C11: Poverty Profile for Sergipe}

\section{Sergipe}

Total

Gender

male

female

Race

white

black

mulatto

indig

asian

Age:

$<25$

25 to 45

45 to 65

$>65$

Household Characteristics

No. of $<5$

No .of $5 \_15$

No. of $>65$

Location:

urban

rural

Working Class:

carteira

yes

no

active

yes

no

worked

yes

no

Work Sector:

Agri.

Ind.

Service

Social

Public

Other

Work Position:

employee

self-employed

employer $\begin{array}{lllllllll}1981 & 1985 & 1988 & 1990 & 1993 & 1995 & 1997 & 1998 & 1999\end{array}$

$\begin{array}{lllllllll}42.8 & 45.7 & 49.5 & 59.7 & 58.5 & 46.2 & 45.9 & 44.1 & 47.2\end{array}$

$\begin{array}{lllllllll}48.1 & 45.8 & 48.9 & 48.7 & 47.8 & 42.7 & 39.0 & 37.6 & 41.3\end{array}$

$\begin{array}{lllllllll}39.1 & 47.9 & 48.6 & 56.3 & 46.7 & 38.1 & 44.8 & 38.9 & 41.6\end{array}$

$\begin{array}{lllllll}40.1 & 35.5 & 33.8 & 30.0 & 28.6 & 28.0 & 26.8\end{array}$

$\begin{array}{lllllll}67.6 & 52.7 & 45.5 & 52.2 & 40.8 & 38.2 & 45.3\end{array}$

$\begin{array}{lllllll}51.0 & 54.3 & 52.3 & 43.6 & 43.9 & 40.9 & 45.2\end{array}$

$\begin{array}{lllll}50.1 & 0.0 & 0.0 & 0.0 & 0.0\end{array}$

$\begin{array}{lllllllll}50.0 & 45.2 & 50.6 & 59.0 & 69.6 & 62.9 & 67.1 & 57.9 & 63.8\end{array}$

$\begin{array}{lllllllll}48.2 & 52.6 & 50.9 & 51.3 & 56.5 & 47.0 & 45.1 & 45.7 & 47.3\end{array}$

$\begin{array}{lllllllll}46.4 & 42.9 & 50.3 & 46.1 & 43.8 & 36.4 & 36.7 & 28.7 & 37.0\end{array}$

$\begin{array}{lllllllll}38.3 & 34.0 & 39.1 & 51.0 & 17.5 & 19.0 & 17.4 & 14.8 & 17.0\end{array}$

$\begin{array}{lllllllll}49.4 & 55.1 & 52.4 & 57.3 & 64.1 & 55.3 & 66.5 & 54.2 & 62.9\end{array}$

$\begin{array}{lllllllll}47.0 & 42.6 & 48.5 & 47.2 & 47.7 & 42.1 & 46.0 & 42.2 & 46.6\end{array}$

$\begin{array}{lllllllll}40.8 & 36.7 & 39.0 & 50.6 & 21.7 & 22.0 & 20.0 & 19.5 & 22.6\end{array}$

$\begin{array}{lllllllll}33.5 & 40.2 & 38.3 & 42.3 & 42.5 & 36.6 & 35.8 & 33.6 & 35.4\end{array}$

$\begin{array}{lllllllll}61.8 & 57.2 & 60.9 & 60.2 & 60.8 & 54.3 & 53.5 & 50.6 & 58.1\end{array}$

$\begin{array}{lllllllll}28.3 & 31.3 & 34.0 & 44.1 & 41.4 & 34.8 & 29.1 & 33.5 & 32.1\end{array}$

$\begin{array}{lllllllll}66.3 & 65.6 & 65.5 & 59.0 & 81.0 & 58.3 & 63.7 & 58.2 & 61.2\end{array}$

$\begin{array}{llllll}49.9 & 52.0 & 44.3 & 41.2 & 40.1 & 43.3\end{array}$

$\begin{array}{llllll}52.1 & 31.4 & 30.9 & 38.8 & 29.3 & 34.6\end{array}$

$\begin{array}{lllllllll}47.4 & 47.1 & 50.3 & 49.8 & 50.3 & 42.2 & 38.6 & 38.0 & 41.0\end{array}$

$\begin{array}{lllllllll}42.5 & 43.2 & 43.7 & 52.1 & 40.3 & 39.8 & 46.1 & 38.1 & 42.4\end{array}$

$\begin{array}{lllllllll}65.7 & 66.2 & 66.9 & 60.4 & 63.8 & 56.9 & 53.6 & 54.8 & 62.7\end{array}$

$\begin{array}{llllllllll}42.4 & 43.3 & 45.0 & 51.5 & 50.6 & 36.5 & 33.6 & 33.6 & 36.3\end{array}$

$\begin{array}{llllllllll}35.3 & 33.3 & 39.6 & 43.2 & 43.2 & 34.6 & 35.2 & 33.7 & 34.0\end{array}$

$\begin{array}{llllllllll}9.1 & 30.2 & 38.3 & 35.7 & 25.5 & 36.0 & 19.6 & 26.9 & 19.3\end{array}$

$\begin{array}{llllllllll}33.3 & 27.7 & 26.6 & 32.3 & 40.0 & 33.3 & 25.8 & 17.6 & 15.3\end{array}$

$\begin{array}{lllllllll}12.5 & 19.1 & 6.2 & 11.1 & 50.0 & 36.4 & 50.0 & 0.0 & 18.8\end{array}$

$\begin{array}{lllllllll}45.8 & 45.9 & 48.1 & 51.7 & 56.8 & 43.5 & 40.6 & 40.9 & 41.6\end{array}$

$\begin{array}{rrrrrrrrr}50.8 & 52.3 & 54.9 & 49.9 & 44.8 & 42.1 & 40.5 & 34.9 & 41.3\end{array}$

$\begin{array}{lllllllll}0.0 & 8.6 & 17.8 & 19.5 & 17.2 & 0.0 & 10.6 & 4.9 & 9.3\end{array}$ 
Sergipe

Tenure

$<1$

$>1$

1 to 3

3 to 5

$>5$

Education

Read and Write

yes

no

Years of Schooling:

no education or $<1$

1 to 4

4 to 8

8 to 12

more than 12

NA

Waste Disposal

collected
burnt
dumped on unused land, river, sea
other

Water Supply

piped

not piped

NA

Sanitation

Sew.Sys. \& Sep. Tank 1

Septic Tank 2

Rudimental Cespit

Drain

River or Lake

Other

NA

none

Electricity

$$
\text { yes }
$$

no

Fridge:

$$
\text { yes }
$$

no

Cooker:

$$
\text { yes }
$$

no

Radio:

$$
\text { yes }
$$

no

TV:

$$
\text { yes }
$$

no
198119851988199019931995199719981999

$\begin{array}{llllll}49.6 & 50.1 & 42.4 & 38.9 & 38.0 & 41.2 \\ 47.5 & 47.2 & 40.8 & 37.0 & 35.9 & 40.4 \\ 54.6 & 51.8 & 41.7 & 39.2 & 39.9 & 44.9 \\ 53.2 & 52.1 & 44.5 & 30.8 & 42.6 & 37.9 \\ 45.9 & 44.9 & 39.5 & 36.2 & 34.2 & 38.5\end{array}$

$\begin{array}{lllllllll}31.6 & 33.8 & 33.7 & 38.0 & 42.2 & 38.0 & 35.6 & 34.1 & 35.4\end{array}$

$\begin{array}{lllllllll}61.3 & 59.9 & 64.3 & 64.5 & 56.9 & 48.2 & 51.9 & 46.8 & 54.4\end{array}$

$\begin{array}{lllllllll}61.6 & 61.0 & 64.8 & 63.6 & 55.5 & 49.7 & 50.3 & 45.2 & 52.3\end{array}$

$\begin{array}{lllllllll}50.5 & 45.3 & 53.5 & 60.5 & 53.5 & 43.2 & 45.4 & 41.8 & 50.2\end{array}$

$\begin{array}{lllllllll}22.1 & 35.1 & 32.4 & 40.2 & 47.3 & 44.4 & 55.6 & 45.0 & 39.6\end{array}$

$\begin{array}{lllllllll}4.5 & 12.6 & 13.4 & 19.1 & 26.0 & 24.4 & 20.5 & 26.4 & 23.2\end{array}$

$\begin{array}{lllllllll}0.0 & 0.0 & 2.5 & 2.8 & 10.2 & 12.2 & 3.4 & 6.7 & 1.2\end{array}$

$\begin{array}{lllllllll}0.0 & 0.0 & 100.0 & 0.0 & 33.3 & 50.0 & 42.9 & 66.7 & 50.0\end{array}$

$\begin{array}{lllllllll}23.5 & 29.5 & 29.7 & 36.6 & 39.6 & 33.8 & 32.2 & 32.6 & 34.2\end{array}$

$\begin{array}{lllllllll}59.1 & 47.7 & 50.8 & 55.8 & 60.8 & 58.1 & 60.7 & 52.5 & 55.3\end{array}$

$\begin{array}{lllllllll}59.6 & 60.8 & 66.8 & 64.4 & 60.2 & 49.6 & 57.2 & 53.8 & 64.8\end{array}$

$\begin{array}{llllllll}0.0 & 66.6 & 0.0 & 20.0 & 66.7 & 50.0 & 25.0 & 0.0\end{array}$

$\begin{array}{lllllllll}28.1 & 36.0 & 39.2 & 42.9 & 39.5 & 33.8 & 32.3 & 34.6 & 38.5\end{array}$

$\begin{array}{llllllllll}55.3 & 60.1 & 68.6 & 65.4 & 40.0 & 42.9 & 38.5 & 31.7 & 34.3\end{array}$

$\begin{array}{lllllllll}63.6 & 60.4 & 58.6 & 60.3 & 62.2 & 55.6 & 59.6 & 56.3 & 65.3\end{array}$

$$
\begin{aligned}
& \begin{array}{lllllllll}
8.0 & 11.6 & 15.0 & 20.8 & 26.6 & 25.1 & 24.5 & 22.6 & 24.3
\end{array} \\
& \begin{array}{lllllllll}
7.9 & 19.2 & 22.5 & 25.4 & 43.1 & 41.6 & 35.7 & 38.2 & 35.0
\end{array} \\
& \begin{array}{lllllllll}
43.5 & 39.2 & 47.9 & 52.0 & 51.4 & 38.6 & 45.5 & 39.1 & 49.1
\end{array} \\
& \begin{array}{lllll}
47.6 & 66.7 & 37.5 & 66.7 & 31.2
\end{array} \\
& \begin{array}{lllll}
66.7 & 100.0 & 33.4 & 50.0 & 25.0
\end{array} \\
& 0.0
\end{aligned}
$$

$\begin{array}{lllllllll}32.1 & 37.1 & 39.5 & 43.5 & 45.1 & 39.1 & 38.9 & 37.7 & 40.6\end{array}$ $\begin{array}{lllllllll}66.9 & 66.2 & 74.0 & 72.6 & 64.7 & 62.2 & 66.7 & 43.9 & 61.8\end{array}$

$\begin{array}{lllllllll}18.0 & 24.5 & 27.6 & 33.2 & 34.9 & 31.7 & 31.3 & 32.6 & 34.4\end{array}$ $\begin{array}{lllllllll}59.5 & 62.0 & 68.0 & 67.6 & 64.7 & 56.9 & 62.5 & 54.3 & 61.0\end{array}$

$\begin{array}{lllllllll}43.4 & 43.2 & 47.9 & 49.4 & 47.5 & 41.1 & 40.4 & 38.1 & 41.2\end{array}$ $\begin{array}{lllllllll}70.5 & 65.7 & 61.8 & 67.8 & 48.3 & 54.5 & 63.6 & 25.0 & 77.8\end{array}$

$\begin{array}{lllllll}41.0 & 43.9 & 43.0 & 38.4 & 38.7 & 35.6 & 39.4\end{array}$ $\begin{array}{lllllll}65.3 & 67.1 & 61.2 & 57.1 & 52.7 & 52.1 & 56.2\end{array}$

$\begin{array}{lllllll}31.7 & 35.0 & 39.8 & 35.6 & 37.5 & 36.4 & 39.2\end{array}$ $\begin{array}{lllllll}67.2 & 69.5 & 62.1 & 57.0 & 54.0 & 46.2 & 54.9\end{array}$ 
Appendix C

Sergipe

Housing Status:

own, paid

own, still paying

rented

ceded

other

Durable House

yes

no
198119851988199019931995199719981999

$\begin{array}{rrrrrrrrr}50.5 & 50.2 & 54.1 & 54.0 & 47.8 & 42.9 & 43.2 & 40.0 & 42.4 \\ 12.3 & 16.1 & 11.1 & 24.2 & 29.1 & 27.0 & 12.3 & 17.0 & 26.0 \\ 34.7 & 39.6 & 40.0 & 44.6 & 48.2 & 36.4 & 38.2 & 34.1 & 31.6 \\ 67.2 & 55.1 & 59.1 & 60.2 & 61.5 & 56.7 & 46.5 & 47.7 & 57.5 \\ 0.0 & 71.5 & 50.0 & 0.0 & 90.0 & 40.0 & 60.0 & 33.3 & 55.6 \\ & & & & & & & & \\ 40.4 & 40.8 & 43.4 & 47.3 & 46.5 & 40.6 & 39.0 & 36.8 & 40.1 \\ 100.0 & & 100.0 & 33.3 & 57.1 & 77.8 & 40.0 & 44.5 & 25.0\end{array}$




\section{Table C12: Poverty Profile for Bahia}

Bahia

Total

Gender

male

female

Race

white

black

mulatto

indig

asian

Age:

$<25$

25 to 45

45 to 65

$>65$

No. of $<5$

No .of 5_15

No. of $>65$

Location:

urban

rural

Working Class:

carteira

yes

no

active

yes

no

worked

yes

no

Work Sector:

Agri.

Ind.

Service

Social

Public

Other

Work Position:

employee

self-employed employer
198119851988199019931995199719981999

$\begin{array}{lllllllll}40.7 & 44.7 & 47.7 & 54.9 & 54.6 & 43.0 & 43.5 & 41.5 & 42.2\end{array}$

$\begin{array}{lllllllll}40.6 & 45.4 & 47.5 & 54.3 & 54.8 & 43.3 & 43.6 & 41.8 & 42.2\end{array}$

$\begin{array}{llllllllll}41.1 & 41.5 & 48.3 & 57.1 & 53.9 & 42.3 & 43.2 & 40.8 & 42.3\end{array}$

$\begin{array}{lllllll}40.4 & 44.6 & 42.0 & 33.6 & 33.9 & 34.4 & 33.0\end{array}$

$\begin{array}{llllllll}51.7 & 63.7 & 55.7 & 42.1 & 44.8 & 45.2 & 43.7\end{array}$

$\begin{array}{lllllll}49.5 & 57.3 & 58.8 & 46.3 & 47.2 & 43.4 & 45.5\end{array}$

$\begin{array}{lllll}77.6 & 70.8 & 38.5 & 47.8 & 38.9\end{array}$

$\begin{array}{llllllll}11.2 & 0.0 & 48.0 & 0.0 & 20.5 & 36.8 & 47.6\end{array}$

$\begin{array}{lllllllll}33.9 & 45.6 & 47.3 & 59.0 & 72.0 & 58.5 & 64.2 & 60.9 & 60.2\end{array}$

$\begin{array}{lllllllll}45.1 & 48.0 & 50.2 & 54.7 & 60.4 & 49.6 & 50.0 & 48.2 & 49.5\end{array}$

$\begin{array}{lllllllll}38.0 & 42.9 & 46.5 & 53.4 & 52.3 & 40.4 & 39.5 & 38.1 & 39.6\end{array}$

$\begin{array}{lllllllll}35.7 & 37.6 & 42.6 & 56.7 & 33.3 & 20.8 & 24.5 & 17.1 & 17.4\end{array}$

$\begin{array}{lllllllll}45.2 & 55.2 & 52.9 & 64.1 & 69.7 & 59.3 & 65.6 & 59.3 & 61.0\end{array}$

$\begin{array}{llllllllll}41.9 & 48.1 & 48.1 & 57.8 & 57.4 & 46.4 & 52.7 & 45.1 & 46.6\end{array}$

$\begin{array}{lllllllll}34.2 & 37.5 & 44.9 & 55.0 & 37.3 & 24.7 & 27.1 & 21.6 & 18.9\end{array}$

$\begin{array}{lllllllll}32.7 & 31.4 & 34.8 & 43.7 & 46.7 & 36.5 & 37.3 & 35.3 & 36.6\end{array}$

$\begin{array}{llllllllll}49.7 & 60.4 & 64.4 & 70.0 & 68.3 & 54.9 & 54.3 & 53.0 & 52.4\end{array}$

$\begin{array}{lllllllll}25.4 & 28.2 & 28.2 & 42.4 & 41.7 & 33.5 & 29.7 & 28.9 & 27.8\end{array}$

$\begin{array}{lllllllll}55.3 & 58.4 & 63.7 & 71.8 & 77.5 & 58.1 & 59.0 & 56.8 & 61.2\end{array}$

$\begin{array}{llllll}53.9 & 56.4 & 44.9 & 45.3 & 43.0 & 44.4\end{array}$ $\begin{array}{lllllll}59.5 & 46.8 & 35.6 & 37.3 & 35.7 & 33.9\end{array}$

$\begin{array}{lllllllll}41.0 & 45.6 & 47.6 & 53.9 & 55.4 & 42.9 & 44.0 & 41.3 & 42.5\end{array}$ $\begin{array}{lllllllll}39.4 & 40.7 & 48.0 & 58.6 & 52.0 & 43.4 & 42.3 & 42.2 & 41.5\end{array}$

$\begin{array}{lllllllll}51.6 & 62.6 & 66.3 & 71.3 & 69.5 & 60.0 & 60.8 & 56.3 & 58.3\end{array}$ $\begin{array}{llllllllll}32.1 & 35.0 & 37.7 & 47.2 & 52.8 & 37.9 & 35.5 & 36.9 & 39.3\end{array}$

$\begin{array}{llllllllll}31.4 & 29.5 & 31.6 & 38.6 & 43.3 & 31.3 & 32.9 & 31.7 & 29.9\end{array}$

$\begin{array}{lllllllll}21.0 & 18.8 & 23.9 & 32.9 & 30.3 & 20.7 & 25.9 & 22.0 & 20.1\end{array}$

$\begin{array}{lllllllll}23.7 & 26.3 & 31.7 & 43.8 & 44.0 & 26.9 & 25.1 & 23.8 & 20.1\end{array}$

$\begin{array}{lllllllll}10.7 & 17.5 & 11.2 & 17.6 & 33.2 & 23.2 & 36.0 & 38.7 & 34.4\end{array}$

$\begin{array}{lllllllll}39.0 & 42.6 & 45.7 & 55.9 & 56.9 & 42.8 & 42.0 & 40.8 & 42.6\end{array}$

$\begin{array}{lllllllll}45.1 & 52.3 & 53.1 & 56.5 & 57.0 & 45.3 & 48.7 & 44.8 & 44.9\end{array}$

$\begin{array}{lllllllll}5.4 & 6.1 & 12.4 & 16.0 & 15.0 & 7.6 & 3.5 & 6.7 & 8.1\end{array}$ 
Bahia

Tenure

$<1$

$>1$

1 to 3

3 to 5

$>5$

Education

Read and Write

yes

no

Years of Schooling:

no education or $<1$

1 to 4

4 to 8

8 to 12

more than 12

NA

Waste Disposal

collected

burnt

dumped on unused land, river, sea other

Water Supply

piped

not piped

NA

Sanitation

Sew.Sys. \& Sep. Tank 1

Septic Tank 2

Rudimental Cespit

Drain

River or Lake

Other

NA

none

Electricity

yes

no

Fridge:

yes

no

Cooker:

yes

no

Radio:

yes

no

TV:

yes

no
198119851988199019931995199719981999

$$
\begin{array}{llllll}
53.5 & 55.2 & 43.0 & 44.0 & 41.2 & 42.3 \\
52.8 & 52.2 & 40.9 & 42.4 & 39.5 & 40.6 \\
52.2 & 55.9 & 43.7 & 44.4 & 43.3 & 42.3 \\
48.2 & 50.4 & 42.3 & 40.4 & 40.2 & 39.3 \\
53.0 & 51.1 & 39.8 & 41.9 & 38.2 & 40.0
\end{array}
$$

$\begin{array}{lllllllll}31.9 & 35.5 & 37.0 & 42.5 & 48.8 & 37.4 & 38.1 & 36.4 & 38.0\end{array}$

$\begin{array}{lllllllll}52.6 & 56.9 & 65.1 & 73.7 & 65.0 & 53.5 & 54.0 & 52.2 & 50.9\end{array}$

$\begin{array}{lllllllll}51.3 & 56.4 & 63.2 & 71.9 & 64.1 & 52.4 & 53.1 & 50.6 & 49.7\end{array}$

$\begin{array}{lllllllll}45.8 & 53.8 & 54.8 & 62.9 & 63.7 & 48.2 & 50.9 & 48.5 & 49.1\end{array}$

$\begin{array}{lllllllll}26.3 & 27.9 & 34.6 & 44.0 & 51.4 & 39.5 & 42.7 & 37.9 & 41.0\end{array}$

$\begin{array}{lllllllll}8.2 & 8.3 & 14.1 & 17.1 & 25.3 & 18.6 & 18.9 & 20.9 & 23.8\end{array}$

$\begin{array}{lllllllll}0.2 & 1.0 & 2.4 & 4.0 & 7.0 & 2.7 & 1.8 & 1.2 & 2.2\end{array}$ $\begin{array}{lllllllll}25.6 & 21.2 & 26.6 & 67.7 & 66.7 & 42.5 & 0.0 & 64.3 & 42.0\end{array}$

$\begin{array}{lllllllll}19.7 & 22.2 & 25.9 & 35.3 & 41.2 & 31.9 & 34.4 & 32.5 & 34.5\end{array}$

$\begin{array}{lllllllll}45.2 & 47.4 & 57.2 & 66.6 & 64.1 & 52.5 & 50.8 & 51.4 & 50.7\end{array}$

$\begin{array}{lllllllll}47.2 & 53.0 & 58.7 & 68.6 & 69.4 & 55.8 & 57.4 & 55.8 & 56.0\end{array}$

$\begin{array}{lllllllll}7.1 & 32.3 & 14.0 & 45.3 & 59.1 & 54.5 & 39.1 & 38.2 & 33.3\end{array}$

$\begin{array}{lllllllll}27.2 & 28.3 & 31.6 & 40.7 & 40.5 & 31.6 & 33.0 & 45.0 & 43.0\end{array}$

$\begin{array}{lllllllll}47.3 & 55.8 & 61.4 & 68.9 & 54.4 & 44.5 & 38.8 & 31.7 & 33.2\end{array}$

$\begin{array}{lllllllll}51.9 & 62.8 & 66.7 & 76.0 & 69.2 & 56.8 & 58.6 & 56.5 & 56.7\end{array}$

$\begin{array}{lllllllll}20.0 & 16.5 & 19.5 & 28.3 & 30.4 & 24.0 & 25.1 & 23.8 & 26.1\end{array}$

$\begin{array}{lllllllll}15.7 & 22.7 & 24.3 & 31.7 & 47.3 & 41.5 & 39.7 & 38.0 & 38.7\end{array}$

$\begin{array}{lllllllll}37.1 & 34.8 & 47.7 & 53.9 & 55.9 & 43.5 & 44.9 & 42.8 & 43.5\end{array}$

$\begin{array}{lllll}69.7 & 46.1 & 52.0 & 49.6 & 51.1\end{array}$

$\begin{array}{lllll}58.9 & 36.9 & 47.1 & 33.7 & 39.4\end{array}$

$\begin{array}{lllllllll}25.8 & 33.0 & 31.5 & 54.7 & 67.3 & 38.2 & 43.4 & 73.4 & 62.0\end{array}$

$53.8 \quad 39.9$

$\begin{array}{llll}53.1 & 63.4 & 67.5 & 75.4\end{array}$

$\begin{array}{lllllllll}29.5 & 31.8 & 38.0 & 46.6 & 49.1 & 38.8 & 39.2 & 37.2 & 38.6\end{array}$

$\begin{array}{lllllllll}52.3 & 64.3 & 69.5 & 74.9 & 70.4 & 57.4 & 59.3 & 58.9 & 57.5\end{array}$

$\begin{array}{lllllllll}17.8 & 18.8 & 23.4 & 32.0 & 36.2 & 27.4 & 30.9 & 29.3 & 30.3\end{array}$ $\begin{array}{lllllllll}51.0 & 59.3 & 65.2 & 72.7 & 69.6 & 57.3 & 59.4 & 57.1 & 58.5\end{array}$

$\begin{array}{lllllllll}38.9 & 43.5 & 47.0 & 53.5 & 54.1 & 42.5 & 43.4 & 41.5 & 42.2\end{array}$ $\begin{array}{lllllllll}50.4 & 55.0 & 62.0 & 72.8 & 70.4 & 59.8 & 49.4 & 40.5 & 48.1\end{array}$

$\begin{array}{lllllll}41.8 & 48.2 & 50.6 & 40.6 & 42.0 & 39.8 & 40.7\end{array}$ $\begin{array}{lllllll}62.2 & 71.2 & 66.7 & 53.4 & 52.6 & 51.6 & 50.0\end{array}$

$\begin{array}{lllllll}26.6 & 35.8 & 41.8 & 34.2 & 38.4 & 36.0 & 37.3\end{array}$

$\begin{array}{llllllll}65.4 & 72.5 & 68.7 & 56.7 & 55.5 & 55.9 & 54.8\end{array}$ 
Bahia

Housing Status:

own, paid

own, still paying

rented

ceded

other

Durable House

yes

no
198119851988199019931995199719981999

$\begin{array}{rrrrrrrrr}44.2 & 48.7 & 51.4 & 59.0 & 56.5 & 43.8 & 45.6 & 42.5 & 43.3 \\ 5.3 & 10.0 & 12.2 & 11.6 & 19.0 & 9.4 & 15.6 & 12.8 & 15.6 \\ 22.6 & 25.1 & 29.2 & 35.3 & 38.1 & 32.8 & 27.5 & 30.5 & 29.5 \\ 47.5 & 51.6 & 57.6 & 63.7 & 67.2 & 54.3 & 49.2 & 51.6 & 52.5 \\ 24.3 & 30.2 & 27.6 & 46.0 & 55.6 & 46.4 & 32.7 & 41.3 & 45.1 \\ & & & & & & & & \\ 38.0 & 42.8 & 46.0 & 53.4 & 53.4 & 41.8 & 42.8 & 40.1 & 41.0 \\ 61.5 & 60.3 & 69.6 & 82.9 & 65.0 & 56.1 & 56.8 & 51.6 & 71.9\end{array}$


Table D1: Differences in the Probability of being poor in the NE versus rest of Brazil

\begin{tabular}{|c|c|c|c|c|c|c|c|}
\hline \multicolumn{5}{|c|}{ Probit estimates } & \multicolumn{3}{|c|}{$\begin{array}{l}\text { Number of obs }=38727 \\
\text { LR chi2 }(41)=15851.81 \\
\text { Prob }>\text { chi2 }=0.0000 \\
\text { Pseudo R2 }=0.3987\end{array}$} \\
\hline P0 & $\mathrm{dF} / \mathrm{dx}$ & Std.Error & $\mathrm{Z}$ & $\mathrm{P}>|\mathrm{z}|$ & $\mathrm{x}$-bar & {$[95 \%$} & C.I.] \\
\hline age & -0.0105 & 0.0012 & -8.54 & 0.00 & & -0.0129 & -0.0081 \\
\hline age_2 & 0.0001 & 0.0000 & 7.10 & 0.00 & & 0.0001 & 0.0001 \\
\hline fema* & 0.1011 & 0.0080 & 14.63 & 0.00 & & 0.0855 & 0.1166 \\
\hline black* & 0.0508 & 0.0101 & 5.68 & 0.00 & & 0.0311 & 0.0706 \\
\hline mula* & 0.0572 & 0.0047 & 12.67 & 0.00 & & 0.0480 & 0.0663 \\
\hline rural* & 0.0471 & 0.0073 & 7.09 & 0.00 & & 0.0328 & 0.0614 \\
\hline fam & 0.0510 & 0.0056 & 9.04 & 0.00 & & 0.0401 & 0.0619 \\
\hline fsize_2 & -0.0047 & 0.0005 & -8.92 & 0.00 & & -0.0058 & -0.0037 \\
\hline fa_ 5 & 0.1145 & 0.0041 & 29.36 & 0.00 & & 0.1065 & 0.1225 \\
\hline fa5_15 & 0.0796 & 0.0033 & 25.19 & 0.00 & & 0.0732 & 0.0860 \\
\hline fa_65 & -0.0800 & 0.0138 & -5.78 & 0.00 & & -0.1071 & -0.0530 \\
\hline schol2* & -0.0399 & 0.0056 & -6.68 & 0.00 & & -0.0510 & -0.0289 \\
\hline schol3* & -0.0726 & 0.0050 & -11.94 & 0.00 & & -0.0824 & -0.0628 \\
\hline schol4* & -0.1233 & 0.0053 & -19.68 & 0.00 & & -0.1338 & -0.1129 \\
\hline schol5* & -0.1262 & 0.0030 & -13.07 & 0.00 & & -0.1321 & -0.1203 \\
\hline cart* & -0.1153 & 0.0052 & -24.22 & 0.00 & & -0.1255 & -0.1052 \\
\hline agri* & 0.1009 & 0.0159 & 7.55 & 0.00 & & 0.0698 & 0.1320 \\
\hline serv* & -0.0009 & 0.0095 & -0.10 & 0.92 & & -0.0196 & 0.0177 \\
\hline ind* & -0.0079 & 0.0099 & -0.79 & 0.43 & & -0.0273 & 0.0114 \\
\hline public* & -0.0086 & 0.0152 & -0.55 & 0.58 & & -0.0385 & 0.0212 \\
\hline $\mathrm{NE}^{*}$ & 0.2439 & 0.0681 & 4.40 & 0.00 & & 0.1105 & 0.3774 \\
\hline NEage & -0.0028 & 0.0020 & -1.43 & 0.15 & & -0.0066 & 0.0010 \\
\hline NEage_2 & 0.0000 & 0.0000 & 0.79 & 0.43 & & 0.0000 & 0.0001 \\
\hline NEfema* & 0.0128 & 0.0102 & 1.31 & 0.19 & & -0.0072 & 0.0328 \\
\hline NEblack* & -0.0207 & 0.0117 & -1.63 & 0.10 & & -0.0435 & 0.0022 \\
\hline NEmula* & -0.0190 & 0.0069 & -2.61 & 0.01 & & -0.0326 & -0.0054 \\
\hline NErural* & -0.0183 & 0.0087 & -1.98 & 0.05 & & -0.0353 & -0.0013 \\
\hline NEfam & 0.0345 & 0.0087 & 3.99 & 0.00 & & 0.0174 & 0.0516 \\
\hline NEfsiz $\sim 2$ & -0.0023 & 0.0008 & -2.80 & 0.01 & & -0.0039 & -0.0007 \\
\hline NEfa_5 & -0.0289 & 0.0064 & -4.47 & 0.00 & & -0.0415 & -0.0163 \\
\hline NEfa5_15 & -0.0169 & 0.0050 & -3.35 & 0.00 & & -0.0268 & -0.0071 \\
\hline NEfa_65 & -0.0319 & 0.0210 & -1.52 & 0.13 & & -0.0731 & 0.0092 \\
\hline NEschol2* & 0.0017 & 0.0100 & 0.17 & 0.87 & & -0.0180 & 0.0213 \\
\hline NEschol3* & 0.0038 & 0.0119 & 0.33 & 0.74 & & -0.0195 & 0.0272 \\
\hline NEschol4* & -0.0306 & 0.0095 & -2.88 & 0.00 & & -0.0493 & -0.0119 \\
\hline NEschol5* & -0.0814 & 0.0122 & -3.56 & 0.00 & & -0.1053 & -0.0574 \\
\hline NEcart* & 0.0125 & 0.0076 & 1.68 & 0.09 & & -0.0025 & 0.0275 \\
\hline NEagri* & -0.0050 & 0.0168 & -0.29 & 0.77 & & -0.0379 & 0.0280 \\
\hline NEserv* & -0.0025 & 0.0141 & -0.18 & 0.86 & & -0.0302 & 0.0251 \\
\hline NEind* & 0.0161 & 0.0167 & 1.01 & 0.31 & & -0.0166 & 0.0489 \\
\hline NEpublic* & -0.0119 & 0.0221 & -0.51 & 0.61 & & -0.0552 & 0.0314 \\
\hline
\end{tabular}

Note: obs. P.: 2094921, pred. P.:1023421 (at x-bar)

$\left.{ }^{*}\right) \mathrm{dF} / \mathrm{dx}$ is for discrete change of dummy variable from 0 to 1 $\mathrm{Z}$ and $\mathrm{P}>|\mathrm{z}|$ are the test of the underlying coefficient being 0 
Table D2: Differences in Rio Grande do Norte versus rest of NE

\begin{tabular}{|c|c|c|c|c|c|c|c|}
\hline \multicolumn{5}{|c|}{ Probit estimates } & \multicolumn{3}{|c|}{$\begin{array}{l}\text { Number of obs }=10245 \\
\text { LR chi2 }(40)=4711.67 \\
\text { Prob }>\text { chi } 2=0.0000\end{array}$} \\
\hline \multicolumn{5}{|c|}{ Log likelihood $=-4610.54$} & Pseu & o R2 & 3382 \\
\hline $\mathrm{P} 0$ & $\mathrm{dF} / \mathrm{dx}$ & Std.Error & $\mathrm{Z}$ & $\mathrm{P}>|\mathrm{z}|$ & x-bar & {$[95 \%$} & C.I.] \\
\hline age & -0.0285 & 0.0033 & -8.62 & 0.00 & & -0.0350 & -0.0221 \\
\hline age_2 & 0.0003 & 0.0000 & 6.65 & 0.00 & & 0.0002 & 0.0003 \\
\hline fema* & 0.2137 & 0.0165 & 12.94 & 0.00 & & 0.1813 & 0.2461 \\
\hline black* & 0.0538 & 0.0248 & 2.20 & 0.03 & & 0.0053 & 0.1024 \\
\hline mula* & 0.0798 & 0.0134 & 5.87 & 0.00 & & 0.0535 & 0.1061 \\
\hline rural* & 0.0423 & 0.0178 & 2.39 & 0.02 & & 0.0073 & 0.0772 \\
\hline fam & 0.1826 & 0.0141 & 12.86 & 0.00 & & 0.1550 & 0.2103 \\
\hline fsize_2 & -0.0148 & 0.0013 & -10.95 & 0.00 & & -0.0174 & -0.0122 \\
\hline fa_5 & 0.1773 & 0.0113 & 15.79 & 0.00 & & 0.1551 & 0.1994 \\
\hline fa5_15 & 0.1311 & 0.0086 & 15.35 & 0.00 & & 0.1143 & 0.1479 \\
\hline fa_65 & -0.2360 & 0.0337 & -7.01 & 0.00 & & -0.3020 & -0.1701 \\
\hline schol2* & -0.0795 & 0.0160 & -4.87 & 0.00 & & -0.1108 & -0.0481 \\
\hline schol3* & -0.1651 & 0.0167 & -9.08 & 0.00 & & -0.1978 & -0.1325 \\
\hline schol4* & -0.3397 & 0.0140 & -19.89 & 0.00 & & -0.3672 & -0.3122 \\
\hline schol5* & -0.4221 & 0.0068 & -14.09 & 0.00 & & -0.4355 & -0.4088 \\
\hline cart* & -0.1990 & 0.0122 & -16.03 & 0.00 & & -0.2229 & -0.1752 \\
\hline agri* & 0.1772 & 0.0308 & 5.82 & 0.00 & & 0.1169 & 0.2375 \\
\hline serv* & -0.0032 & 0.0233 & -0.14 & 0.89 & & -0.0488 & 0.0424 \\
\hline ind* & 0.0178 & 0.0251 & 0.71 & 0.48 & & -0.0314 & 0.0671 \\
\hline public* & -0.0327 & 0.0382 & -0.84 & 0.40 & & -0.1076 & 0.0421 \\
\hline $\mathrm{RN}^{*}$ & 0.0712 & 0.3441 & 0.21 & 0.83 & & -0.6032 & 0.7455 \\
\hline RNage & 0.0037 & 0.0151 & 0.24 & 0.81 & & -0.0259 & 0.0333 \\
\hline RNage_2 & 0.0000 & 0.0002 & 0.05 & 0.96 & & -0.0004 & 0.0004 \\
\hline RNfema* & -0.0288 & 0.0742 & -0.38 & 0.70 & & -0.1742 & 0.1166 \\
\hline RNblack* & -0.2095 & 0.1529 & -1.06 & 0.29 & & -0.5092 & 0.0903 \\
\hline RNmula* & -0.0910 & 0.0510 & -1.68 & 0.09 & & -0.1910 & 0.0091 \\
\hline RNrural* & 0.0787 & 0.0608 & 1.32 & 0.19 & & -0.0405 & 0.1978 \\
\hline RNfam & -0.0349 & 0.0712 & -0.49 & 0.62 & & -0.1745 & 0.1046 \\
\hline RNfsiz $\sim 2$ & -0.0024 & 0.0067 & -0.36 & 0.72 & & -0.0155 & 0.0107 \\
\hline RNfa_5 & 0.0851 & 0.0509 & 1.67 & 0.10 & & -0.0147 & 0.1850 \\
\hline RNfa5_15 & 0.0505 & 0.0409 & 1.24 & 0.22 & & -0.0295 & 0.1306 \\
\hline RNfa_65 & -0.1813 & 0.2783 & -0.65 & 0.52 & & -0.7268 & 0.3642 \\
\hline RNschol2* & -0.0762 & 0.0642 & -1.13 & 0.26 & & -0.2020 & 0.0495 \\
\hline RNschol3* & -0.0337 & 0.0842 & -0.39 & 0.69 & & -0.1986 & 0.1313 \\
\hline RNschol4* & -0.0213 & 0.0836 & -0.25 & 0.80 & & -0.1852 & 0.1426 \\
\hline RNcart* & 0.0349 & 0.0578 & 0.61 & 0.54 & & -0.0784 & 0.1481 \\
\hline RNagri* & -0.0867 & 0.1092 & -0.75 & 0.45 & & -0.3007 & 0.1274 \\
\hline RNserv* & -0.0690 & 0.0972 & -0.68 & 0.50 & & -0.2596 & 0.1216 \\
\hline RNind* & -0.0294 & 0.1045 & -0.28 & 0.78 & & -0.2342 & 0.1754 \\
\hline RNpublic* & -0.1582 & 0.1212 & -1.12 & 0.26 & & -0.3958 & 0.0794 \\
\hline
\end{tabular}

Note: obs. P.: .4190337, pred. P.:.3723097 (at x-bar)

$\left.{ }^{*}\right) \mathrm{dF} / \mathrm{dx}$ is for discrete change of dummy variable from 0 to 1 $\mathrm{Z}$ and $\mathrm{P}>|\mathrm{z}|$ are the test of the underlying coefficient being 0 
Table D3: Differences in Pernambuco versus rest of NE

\begin{tabular}{|c|c|c|c|c|c|c|}
\hline \multicolumn{5}{|c|}{ Probit estimates } & \multirow{2}{*}{\multicolumn{2}{|c|}{$\begin{array}{l}\text { Number of obs }=10271 \\
\text { LR chi2 }(41)=4743.82 \\
\text { Prob }>\text { chi2 }=0.0000 \\
\text { Pseudo R2 }=0.3398\end{array}$}} \\
\hline \multicolumn{5}{|c|}{ Log likelihood $=-4608.5631$} & & \\
\hline $\mathrm{P} 0$ & $\mathrm{dF} / \mathrm{dx}$ & Std.Error & Z & $\mathrm{P}>|\mathrm{z}|$ & {$[95 \%$} & C.I.] \\
\hline age & -0.0304 & 0.0037 & -8.29 & 0.00 & -0.0376 & -0.0232 \\
\hline age_2 & 0.0003 & 0.0000 & 6.59 & 0.00 & 0.0002 & 0.0004 \\
\hline fema* & 0.2312 & 0.0187 & 12.34 & 0.00 & 0.1946 & 0.2679 \\
\hline black* & 0.0594 & 0.0274 & 2.20 & 0.03 & 0.0057 & 0.1131 \\
\hline mula* & 0.0800 & 0.0153 & 5.17 & 0.00 & 0.0501 & 0.1099 \\
\hline rural* & 0.0517 & 0.0188 & 2.77 & 0.01 & 0.0148 & 0.0886 \\
\hline fam & 0.1907 & 0.0159 & 11.90 & 0.00 & 0.1594 & 0.2219 \\
\hline fsize_2 & -0.0154 & 0.0015 & -10.12 & 0.00 & -0.0184 & -0.0125 \\
\hline fa_5 & 0.1801 & 0.0125 & 14.47 & 0.00 & 0.1555 & 0.2046 \\
\hline fa5_15 & 0.1347 & 0.0096 & 14.12 & 0.00 & 0.1160 & 0.1535 \\
\hline fa_65 & -0.2567 & 0.0386 & -6.64 & 0.00 & -0.3324 & -0.1811 \\
\hline schol2* & -0.0850 & 0.0175 & -4.75 & 0.00 & -0.1193 & -0.0508 \\
\hline schol3* & -0.1612 & 0.0188 & -7.88 & 0.00 & -0.1980 & -0.1244 \\
\hline schol4* & -0.3449 & 0.0154 & -18.23 & 0.00 & -0.3751 & -0.3147 \\
\hline schol5* & -0.4201 & 0.0080 & -12.84 & 0.00 & -0.4357 & -0.4044 \\
\hline cart* & -0.2087 & 0.0137 & -14.91 & 0.00 & -0.2356 & -0.1819 \\
\hline agri* & 0.1703 & 0.0334 & 5.16 & 0.00 & 0.1048 & 0.2359 \\
\hline serv* & -0.0062 & 0.0258 & -0.24 & 0.81 & -0.0567 & 0.0444 \\
\hline ind* & 0.0146 & 0.0277 & 0.53 & 0.60 & -0.0398 & 0.0690 \\
\hline public* & -0.0532 & 0.0405 & -1.28 & 0.20 & -0.1326 & 0.0262 \\
\hline $\mathrm{PE}^{*}$ & -0.0154 & 0.1597 & -0.10 & 0.92 & -0.3284 & 0.2976 \\
\hline PEage & 0.0087 & 0.0076 & 1.14 & 0.25 & -0.0062 & 0.0236 \\
\hline PEage_2 & -0.0001 & 0.0001 & -1.17 & 0.24 & -0.0003 & 0.0001 \\
\hline PEfema* & -0.0654 & 0.0336 & -1.88 & 0.06 & -0.1311 & 0.0004 \\
\hline PEblack* & -0.0364 & 0.0597 & -0.60 & 0.55 & -0.1533 & 0.0805 \\
\hline PEmula* & -0.0167 & 0.0294 & -0.57 & 0.57 & -0.0743 & 0.0409 \\
\hline PErural* & -0.0057 & 0.0419 & -0.14 & 0.89 & -0.0879 & 0.0765 \\
\hline PEfam & -0.0421 & 0.0322 & -1.31 & 0.19 & -0.1052 & 0.0210 \\
\hline PEfsiz 2 & 0.0021 & 0.0030 & 0.69 & 0.49 & -0.0039 & 0.0081 \\
\hline PEfa_5 & 0.0058 & 0.0260 & 0.22 & 0.82 & -0.0451 & 0.0567 \\
\hline PEfa5_15 & -0.0058 & 0.0196 & -0.30 & 0.77 & -0.0443 & 0.0327 \\
\hline PEfa_65 & 0.0710 & 0.0769 & 0.92 & 0.36 & -0.0797 & 0.2217 \\
\hline PEschol2* & 0.0079 & 0.0394 & 0.20 & 0.84 & -0.0692 & 0.0851 \\
\hline PEschol3* & -0.0218 & 0.0430 & -0.50 & 0.62 & -0.1062 & 0.0625 \\
\hline PEschol4* & 0.0312 & 0.0455 & 0.69 & 0.49 & -0.0579 & 0.1203 \\
\hline PEschol5* & -0.1291 & 0.1439 & -0.81 & 0.42 & -0.4112 & 0.1529 \\
\hline PEcart* & 0.0546 & 0.0288 & 1.92 & 0.06 & -0.0018 & 0.1111 \\
\hline PEagri* & -0.0008 & 0.0718 & -0.01 & 0.99 & -0.1415 & 0.1399 \\
\hline PEserv* & -0.0093 & 0.0534 & -0.17 & 0.86 & -0.1140 & 0.0954 \\
\hline PEind* & 0.0015 & 0.0576 & 0.03 & 0.98 & -0.1114 & 0.1145 \\
\hline PEpublic* & 0.0527 & 0.0965 & 0.55 & 0.58 & -0.1366 & 0.2419 \\
\hline
\end{tabular}

Note: obs. P.: .4179, pred. P.:3892 (at x-bar)

(*) $\mathrm{dF} / \mathrm{dx}$ is for discrete change of dummy variable from 0 to 1 
Table D4: Differences in Ceará versus rest of $\mathrm{NE}$

\begin{tabular}{|c|c|c|c|c|c|c|}
\hline Probit estim & $=-4609$. & 5102 & & & \multicolumn{2}{|c|}{$\begin{array}{l}\text { Number of obs }=10271 \\
\text { LR chi2 }(41)=4741.92 \\
\text { Prob }>\text { chi } 2=0.0000 \\
\text { Pseudo R2 }=0.3397\end{array}$} \\
\hline P0 & $\mathrm{dF} / \mathrm{dx}$ & Std.Err. & $\mathrm{Z}$ & $\mathrm{P}>|\mathrm{z}|$ & {$[95 \%$} & C.I.] \\
\hline$\overline{\text { age }}$ & -0.0265 & 0.0036 & -7.40 & 0.00 & -0.0335 & $5 \quad-0.0195$ \\
\hline age 2 & 0.0002 & 0.0000 & 5.76 & 0.00 & 0.0002 & 0.0003 \\
\hline fema* & 0.2099 & 0.0182 & 11.56 & 0.00 & 0.1743 & 0.2456 \\
\hline black* & 0.0366 & 0.0255 & 1.45 & 0.15 & -0.0133 & 0.0865 \\
\hline mula* & 0.0670 & 0.0146 & 4.53 & 0.00 & 0.0384 & 0.0957 \\
\hline rural* & 0.0335 & 0.0180 & 1.88 & 0.06 & -0.0017 & 0.0688 \\
\hline fam & 0.1849 & 0.0151 & 12.18 & 0.00 & 0.1553 & 0.2145 \\
\hline fsize 2 & -0.0155 & 0.0014 & -10.77 & 0.00 & -0.0183 & $\begin{array}{ll}3 & -0.0127\end{array}$ \\
\hline fa_ 5 & 0.1845 & 0.0123 & 15.17 & 0.00 & 0.1604 & 0.2085 \\
\hline fa5_15 & 0.1296 & 0.0092 & 14.12 & 0.00 & 0.1115 & 0.1477 \\
\hline fa_65 & -0.2486 & 0.0374 & -6.64 & 0.00 & -0.3219 & -0.1753 \\
\hline schol2* & -0.0981 & 0.0171 & -5.57 & 0.00 & -0.1316 & $\begin{array}{ll}5 & -0.0645\end{array}$ \\
\hline schol3* & -0.1836 & 0.0179 & -9.25 & 0.00 & -0.2187 & $7-0.1486$ \\
\hline schol4* & -0.3515 & 0.0150 & -19.02 & 0.00 & -0.3808 & $\begin{array}{ll}3 & -0.3222\end{array}$ \\
\hline schol5* & -0.4261 & 0.0072 & -13.17 & 0.00 & -0.4402 & -0.4121 \\
\hline cart* & -0.1990 & 0.0133 & -14.70 & 0.00 & -0.2251 & -0.1730 \\
\hline agri* & 0.1670 & 0.0328 & 5.15 & 0.00 & 0.1026 & 0.2313 \\
\hline serv* & -0.0074 & 0.0253 & -0.29 & 0.77 & -0.0571 & 0.0422 \\
\hline ind $^{*}$ & 0.0169 & 0.0275 & 0.62 & 0.54 & -0.0370 & 0.0709 \\
\hline public* & -0.0395 & 0.0394 & -0.98 & 0.33 & -0.1167 & 0.0377 \\
\hline $\mathrm{CE}^{*}$ & 0.0892 & 0.1748 & 0.52 & 0.61 & -0.2534 & 0.4318 \\
\hline CEage & -0.0082 & 0.0082 & -1.00 & 0.32 & -0.0242 & 0.0079 \\
\hline CEage_2 & 0.0001 & 0.0001 & 0.75 & 0.45 & -0.0001 & 0.0003 \\
\hline CEfema* & 0.0140 & 0.0393 & 0.36 & 0.72 & -0.0630 & 0.0909 \\
\hline CEblack* & 0.0848 & 0.0999 & 0.87 & 0.39 & -0.1109 & 0.2805 \\
\hline CEmula* & 0.0350 & 0.0335 & 1.05 & 0.29 & -0.0307 & 0.1007 \\
\hline CErural* & 0.1125 & 0.0559 & 2.05 & 0.04 & 0.0030 & 0.2221 \\
\hline CEfam & -0.0207 & 0.0379 & -0.55 & 0.59 & -0.0949 & 0.0536 \\
\hline CEfsiz $\sim 2$ & 0.0032 & 0.0037 & 0.86 & 0.39 & -0.0041 & 0.0104 \\
\hline CEfa_5 & -0.0135 & 0.0277 & -0.49 & 0.63 & -0.0679 & 0.0409 \\
\hline CEfa $\overline{5} \_15$ & 0.0178 & 0.0219 & 0.81 & 0.42 & -0.0251 & 0.0607 \\
\hline CEfa_- 65 & 0.0471 & 0.0828 & 0.57 & 0.57 & -0.1151 & 0.2093 \\
\hline CEschol2* & 0.0611 & 0.0421 & 1.47 & 0.14 & -0.0215 & 0.1437 \\
\hline CEschol3* & 0.0894 & 0.0476 & 1.92 & 0.06 & -0.0039 & 0.1828 \\
\hline CEschol4* & 0.0791 & 0.0487 & 1.65 & 0.10 & -0.0164 & 0.1745 \\
\hline CEschol5* & 0.1219 & 0.1596 & 0.78 & 0.44 & -0.1909 & 0.4347 \\
\hline CEcart* & 0.0105 & 0.0307 & 0.34 & 0.73 & -0.0497 & 0.0707 \\
\hline CEagri* & -0.0120 & 0.0768 & -0.15 & 0.88 & -0.1625 & 0.1386 \\
\hline CEserv* & 0.0033 & 0.0562 & 0.06 & 0.95 & -0.1070 & 0.1135 \\
\hline CEind* & -0.0015 & 0.0591 & -0.03 & 0.98 & -0.1174 & 0.1144 \\
\hline CEpublic* & -0.0721 & 0.1079 & -0.64 & 0.52 & -0.2836 & 0.1394 \\
\hline
\end{tabular}


Table D5: Differences in Maranhão versus rest of NE

\begin{tabular}{|c|c|c|c|c|c|c|c|}
\hline \multicolumn{5}{|c|}{ Probit estimates } & \multicolumn{3}{|c|}{$\begin{array}{l}\text { Number of obs }=10271 \\
\text { LR chi2 }(41)=4747.58 \\
\text { Prob }>\text { chi }=0.0000 \\
\text { Pseudo R2 }=0.3401\end{array}$} \\
\hline P0 & $\mathrm{dF} / \mathrm{dx}$ & Std.Err. & Z & $\mathrm{P}>|\mathrm{z}|$ & & $5 \%$ & C.I.] \\
\hline age & -.0277 & .0032 & -8.50 & 0.00 & 36.655 & -.0340 & -.0213 \\
\hline age_2 & .0002 & .0000 & 6.63 & 0.00 & 1469.9 & .0001 & .0003 \\
\hline fema* & .2081 & .0164 & 12.73 & 0.00 & .2191 & .1760 & .2403 \\
\hline black* & .0451 & .0247 & 1.85 & 0.06 & .0753 & -.0032 & .0935 \\
\hline mula* & .0766 & .0131 & 5.74 & 0.00 & .6428 & .0508 & .1024 \\
\hline rural* & .0592 & .0175 & 3.42 & 0.00 & .2138 & .0248 & .0935 \\
\hline fam & .1788 & .0140 & 12.68 & 0.00 & 3.6958 & .1513 & .2062 \\
\hline fsize_2 & -.0147 & .0013 & -10.96 & 0.00 & 16.563 & -.0173 & -.0121 \\
\hline fa_5 & .1843 & .0112 & |16.58 & 0.00 & .4849 & .1623 & .2063 \\
\hline fa5_15 & .1342 & .0085 & 15.83 & 0.00 & .9062 & .1175 & .1510 \\
\hline fa_65 & -.2336 & .0338 & -6.90 & 0.00 & .0384 & -.2999 & -.1673 \\
\hline schol2* & -.0861 & .0156 & .5 .37 & 0.00 & .2708 & -.1168 & -.0554 \\
\hline schol3* & -.1668 & .0163 & -9.33 & 0.00 & .1697 & -.1988 & -.1348 \\
\hline schol4* & -.3384 & .0137 & -20.15 & 0.00 & .2626 & -.3654 & -.3113 \\
\hline schol5* & -.4255 & .0066 & -13.91 & 0.00 & -.0642 & -4385 & -.4124 \\
\hline cart* & -.1952 & .0120 & -15.95 & 0.00 & .5145 & -.2188 & -.1717 \\
\hline agri* & .1550 & .0305 & 5.15 & 0.00 & .1696 & .0952 & .2148 \\
\hline serv* & -.0135 & .0230 & -0.59 & 0.55 & .4192 & -.0586 & .0316 \\
\hline ind* & .0122 & .0247 & 0.49 & 0.61 & .2743 & -.0363 & .0608 \\
\hline public* & -.0473 & .0368 & -1.25 & 0.21 & .0359 & -.1196 & .0248 \\
\hline $\mathrm{MA}^{*}$ & .2036 & .4184 & 0.49 & 0.62 & .0318 & -.6165 & 1.023 \\
\hline MAage & -.0111 & .0202 & .0 .55 & 0.58 & 1.1378 & -.0508 & .0286 \\
\hline MAage_2 & .0000 & .0002 & 0.24 & 0.80 & 44.922 & -.0041 & .0005 \\
\hline MAfema* & .1267 & .0999 & 1.29 & 0.19 & .0074 & -.0691 & .3225 \\
\hline MAblack* & .1355 & .1665 & 0.83 & 0.40 & .0023 & -.1907 & .4619 \\
\hline MAmula* & -.0660 & .0723 & -0.88 & 0.38 & 0213 & -.2078 & .0757 \\
\hline MArural* & -.1460 & .0595 & -2.16 & 0.03 & .0141 & -.2627 & -.029 \\
\hline Mafam & .0513 & .0785 & 0.65 & 0.51 & .1254 & -.1026 & .2053 \\
\hline MAfsiz 2 & -.0024 & .0070 & -0.34 & 0.73 & .5976 & -.0163 & .0114 \\
\hline MAfa_5 & -.0670 & .0606 & -1.11 & 0.26 & .0181 & -.1859 & .0517 \\
\hline MAfa5_15 & -.0393 & .0445 & -0.88 & 0.37 & .0339 & -.1266 & .0480 \\
\hline MAfa_65* & -.0997 & .1688 & .0 .55 & 0.58 & .0012 & -.4306 & .2311 \\
\hline MAschol2* & .0482 & .1005 & 0.49 & 0.62 & .0098 & -.1488 & .2453 \\
\hline MAschol3* & -.0234 & .1173 & -0.20 & 0.84 & .0042 & -.2534 & -.2064 \\
\hline MAschol4* & -.0090 & .1123 & -0.08 & 0.93 & .0075 & -.2293 & .2111 \\
\hline MAschol5* & .3637 & .1949 & 1.62 & 0.10 & .0019 & 6.018 & .7458 \\
\hline MAcart* & .0332 & .0833 & 0.40 & 0.68 & .0100 & -.1301 & .1965 \\
\hline MAagri* & .2127 & .1510 & 1.40 & 0.16 & .0082 & -.0833 & .5089 \\
\hline MAserv* & .1296 & .1222 & 1.08 & 0.28 & .0125 & -.1099 & .3692 \\
\hline MAind* & -.0284 & .1322 & -0.21 & 0.83 & .0059 & -.2876 & .2307 \\
\hline MApublic* & -.0286 & .2113 & -.013 & 0.89 & .0010 & -.4428 & .3855 \\
\hline
\end{tabular}

Note: $\quad$ obs. P | .4179729 pred. P | .3693274 (at x-bar)

(*) $\mathrm{dF} / \mathrm{dx}$ is for discrete change of dummy variable from 0 to 1 $\mathrm{Z}$ and $\mathrm{P}>|\mathrm{z}|$ are the test of the underlying coefficient being 0 
Table D6: Differences in Piauí versus the rest of NE

\begin{tabular}{|c|c|c|c|c|c|c|c|}
\hline \multicolumn{5}{|c|}{ Probit estimates } & \multicolumn{3}{|c|}{$\begin{array}{l}\text { Number of obs }=10258 \\
\text { LR chi2 }(40)=4751.56 \\
\text { Prob }>\text { chi2 }=0.0000 \\
\text { Pseudo R2 }=0.3407\end{array}$} \\
\hline $\mathrm{P} 0$ & $\mathrm{dF} / \mathrm{dx}$ & Std.Err. & $\mathrm{Z}$ & $\mathrm{P}>|\mathrm{z}|$ & & {$[95 \%$} & C.I.] \\
\hline$\overline{\text { age }}$ & -.0271 & .0032 & -8.31 & 0.000 & 36.65 & -.0335 & -.0207 \\
\hline age 2 & .0002 & .0000 & 6.47 & 0.000 & 1470.27 & .0001 & .0003 \\
\hline fema* & .2183 & .0163 & 13.33 & 0.000 & .2190 & .1862 & .2504 \\
\hline Black* & .0392 & .0246 & 1.61 & 0.107 & .0754 & -.0090 & .0874 \\
\hline mula* & .0695 & .0131 & 5.22 & 0.000 & .6433 & .0437 & .0954 \\
\hline rural* & .0489 & .0172 & 2.87 & 0.004 & .2140 & .0151 & .0826 \\
\hline fam & .1828 & .0139 & 12.98 & 0.000 & 3.696 & .1553 & .2102 \\
\hline fsize_2 & -.0151 & .0013 & -11.33 & 0.000 & 16.57 & -.0177 & -.0125 \\
\hline fa_5 & .1850 & $\mid .0112$ & 16.62 & 0.000 & .4849 & .1630 & .2070 \\
\hline fa $\overline{5} \_15$ & .1346 & .0085 & 15.87 & 0.000 & .9063 & .1179 & .1513 \\
\hline fa_65 & -.2320 & .0335 & -6.91 & 0.000 & .0385 & -.2977 & -.1663 \\
\hline $\operatorname{schol} 2 *$ & -.0806 & .0157 & -5.00 & 0.000 & .2712 & -.1116 & -.0497 \\
\hline schol3* & -.1608 & .0165 & 8.95 & -0.000 & 1700 & -.1932 & -.1284 \\
\hline schol4* & -.3346 & .0139 & 19.80 & 0.000 & -.2630 & 3619 & -.3073 \\
\hline schol5* & -.4228 & 0067 & -14.29 & 0.000 & .0630 & -.4361 & -.4096 \\
\hline cart* & -.1921 & 0120 & -15.65 & 0.000 & .514233 & -.2157 & -.1684 \\
\hline agri* & .1803 & .0303 & 6.01 & 0.000 & .1698 & .12091 & .2397 \\
\hline Serv* & -.0071 & .0229 & -0.31 & 0.755 & .4195 & -.0522 & .0378 \\
\hline ind*| & .0158 & .0247 & 0.64 & 0.522 & .2747 & -.0327 & .0643 \\
\hline public* & -.0556 & .0371 & -1.45 & 0.146 & .0357 & -.1285 & .0171 \\
\hline $\mathrm{PI}^{*}$ & .6635 & .0227 & 2.80 & 0.005 & .0312 & .6189 & .7082 \\
\hline PIage & -.0303 & .0200 & 1.51 & 0.131 & 1.1130 & -.0695 & .0089 \\
\hline PIage_2 & 0002 & .0002 & 1.07 & 0.283 & 43.2279 & -.0002 & .0007 \\
\hline PIfema* & -.1358 & .0785 & -1.54 & 0.123 & .0069 & -.2897 & 0180 \\
\hline PIblack* & .3216 & 72 & 1.86 & 0.063 & .0019 & .0133 & .6298 \\
\hline PImula* & .1676 & .0979 & 1.73 & 0.084 & .0238 & -.0243 & .3596 \\
\hline PIrural* & -.0098 & .0914 & -0.11 & 0.914 & .0080 & -.1890 & .1693 \\
\hline Pifam & -.0862 & .0989 & 0.87 & 0.383 & .1201 & -.2801 & .1075 \\
\hline Pifsiz 2.0 & .0096 & .0107 & 0.90 & 0.369 & .5518 & -.0114 & .0307 \\
\hline PIfa_5 & -.0697 & .0641 & -1.09 & 0.277 & .0160 & -.1954 & .0560 \\
\hline PIfa5_15 & -.0229 & .0488 & -0.47 & 0.639 & .0324 & -.1186 & .0728 \\
\hline PIfa_ $65^{*}$ & -.1897 & .2256 & -0.68 & 0.497 & .0004 & -.6320 & .2524 \\
\hline PIschol2* & -.1517 & .0761 & -1.74 & 0.082 & .0110 & -.3010 & -.0024 \\
\hline PIschol3* & -.2345 & .0732 & -2.31 & 0.021 & .0042 & -.3780 & -.0910 \\
\hline PIschol4* & -.2541 & .0634 & -2.71 & 0.007 & .0078 & -.3785 & -.1297 \\
\hline Picart* & -.1017 & .0677 & -1.40 & 0.162 & .0112 & -.2344 & .0309 \\
\hline PIagri* & -.2612 & .0804 & -2.13 & 0.033 & .0070 & -0418 & -.1035 \\
\hline Piserv* & -.0590 & .1302 & -044 & 0.661 & .0126 & -.3144 & .1962 \\
\hline Piind* & -.0318 & .1456 & -0.22 & 0.829 & .0070 & -.3173 & .2536 \\
\hline PIpublic* & .0424 & .1844 & 0.23 & 0.816 & .0018 & -.3190 & .403 \\
\hline
\end{tabular}

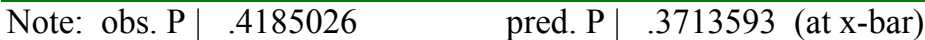

$(*) \mathrm{dF} / \mathrm{dx}$ is for discrete change of dummy variable from 0 to 1 $\mathrm{z}$ and $\mathrm{P}>|\mathrm{z}|$ are the test of the underlying coefficient being 0 
Table D7: Differences in Paraíba versus the rest of NE

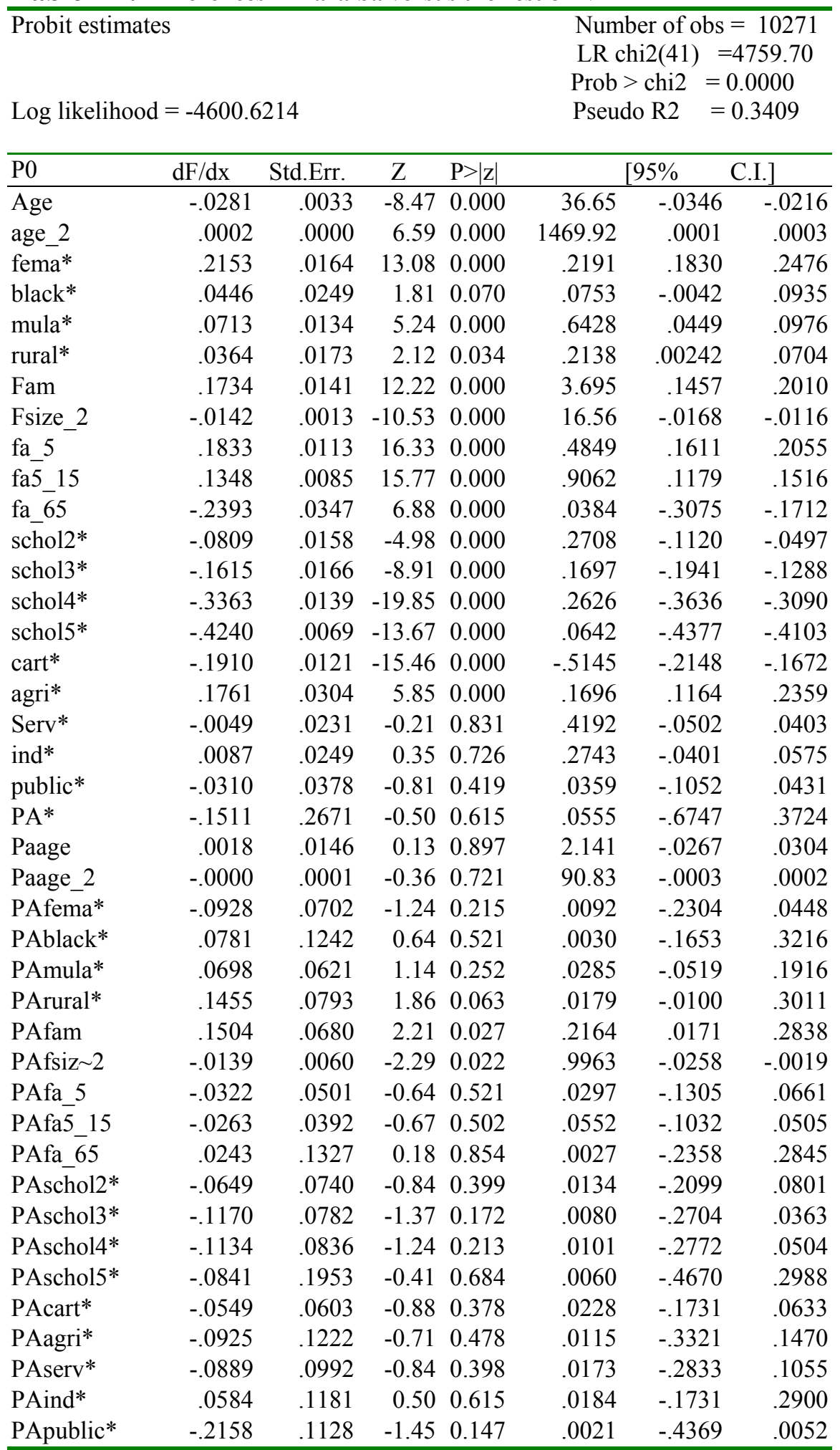

Note: $\quad$ obs. P $\mid .4179729 \quad$ pred. P | .3703122 (at x-bar)

(*) $\mathrm{dF} / \mathrm{dx}$ is for discrete change of dummy variable from 0 to 1 $\mathrm{Z}$ and $\mathrm{P}>|\mathrm{z}|$ are the test of the underlying coefficient being 0 
Table D8: Differences in Pernambuco versus the rest of NE

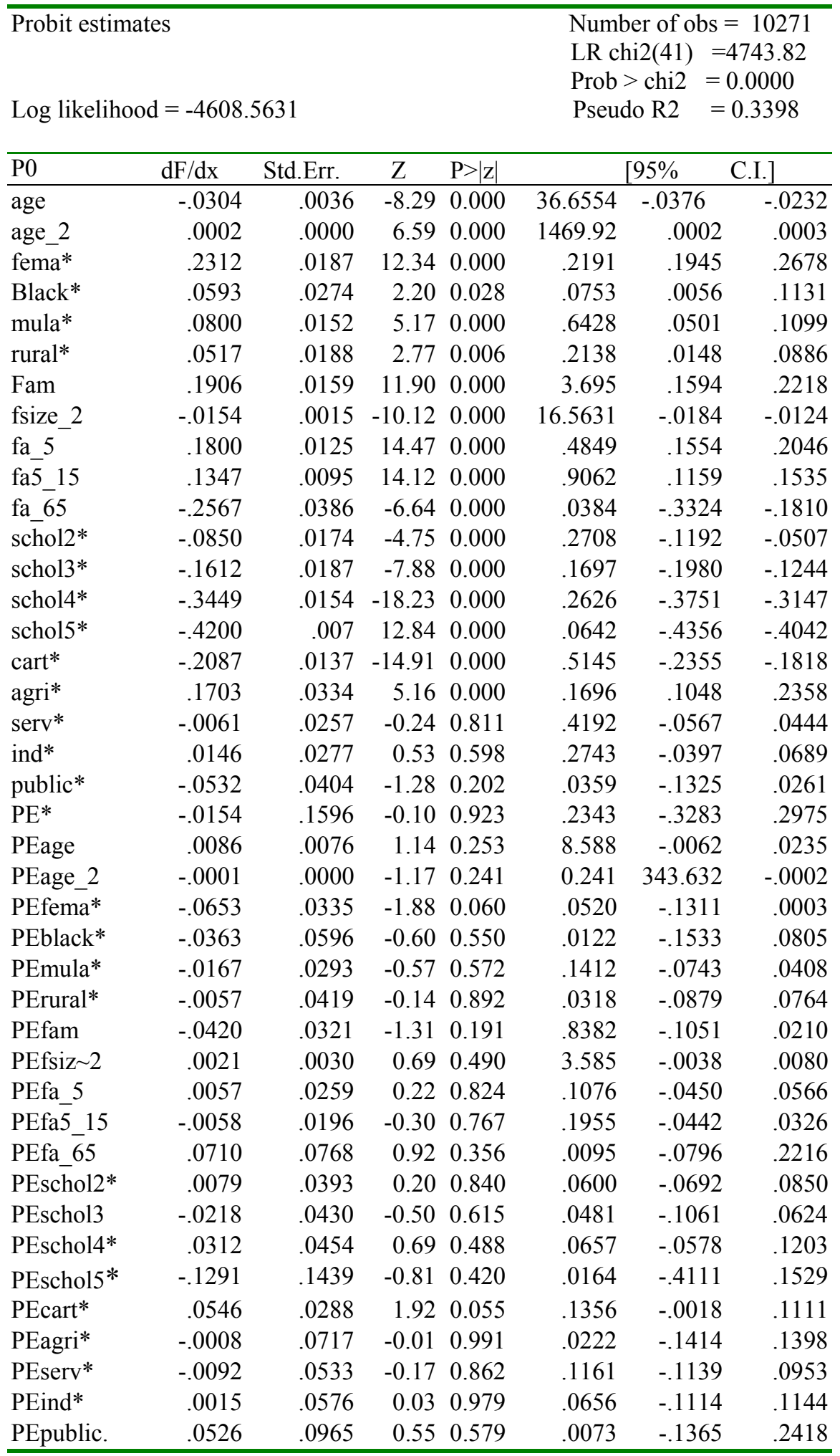

Note: obs. P . .4179729 pred. P .3691868 (at x-bar)

$\mathrm{Z}$ and $\mathrm{P}>|\mathrm{z}|$ are the test of the underlying coefficient being 0 
Table D9: Differences in Alagoas versus the rest of NE

\begin{tabular}{|c|c|c|c|c|c|c|c|}
\hline \multicolumn{5}{|c|}{ Probit estimates } & \multicolumn{3}{|c|}{ Number of obs $=10271$} \\
\hline & & & & & \multirow{3}{*}{\multicolumn{3}{|c|}{$\begin{array}{l}\text { LR chi2 }(41)=4755.78 \\
\text { Prob }>\text { chi2 }=0.0000 \\
\text { Pseudo R2 }=0.3406\end{array}$}} \\
\hline & & & & & & & \\
\hline \multicolumn{5}{|c|}{ Log likelihood $=-4602.5812$} & & & \\
\hline P0 & $\mathrm{dF} / \mathrm{dx}$ & Std.Err. & $Z$ & $\mathrm{P}>|\mathrm{z}|$ & \multicolumn{3}{|c|}{$[95 \%$} \\
\hline age & -.0282 & .0032 & -8.63 & 0.000 & 36.6554 & -.0346 & -.0218 \\
\hline age_2 & .0002 & .0000 & 6.67 & 0.000 & 1469.92 & & .0003 \\
\hline fema* & 2147 & .0164 & 13.11 & 0.000 & 2191 & 1826 & 2469 \\
\hline lack & .0499 & .0251 & 2.01 & 0.044 & .0753 & .0006 & .0992 \\
\hline ula* & .0746 & .0133 & 5.52 & 0.000 & .6428 & .0485 & .1008 \\
\hline ura & .0568 & & 3.28 & 0.001 & .2138 & .0224 & 0911 \\
\hline $\mathrm{am}$ & .1817 & .0141 & 12.80 & 0.000 & 3.6 & & .2093 \\
\hline size 2 & -.0152 & .0013 & -11.21 & 0.000 & 16.5631 & -.0178 & -.0125 \\
\hline 15 & & .0112 & & 0.000 & .4849 & & .2012 \\
\hline a5_1 & & & & & .9062 & & .1519 \\
\hline a_ 65 & & & 83 & & .0384 & -.2 & -.1647 \\
\hline tho & & & 78 & & .2708 & & -.0464 \\
\hline cho & -.16 & .0165 & -9.02 & 0 & .1697 & & -.1304 \\
\hline ho & -.3311 & .0140 & -19.49 & 0.000 & .2626 & & -.3035 \\
\hline ho & -.4249 & .0067 & -13.78 & 0.000 & .0642 & & -.4118 \\
\hline $\mathrm{rt}^{*}$ & -.1965 & .0121 & -15.90 & 0.0 & .5145 & 03 & -.1727 \\
\hline $\mathrm{ri}^{*}$ & & .0305 & 5.26 & 0.0 & .1696 & & .2182 \\
\hline erv* & -.0 & .0229 & -0.38 & 0.7 & .4192 & 38 & .0362 \\
\hline$d^{*}$ & & & & & .2743 & & .0624 \\
\hline ublis & & .03 & -1.10 & & .0359 & & .0315 \\
\hline I * & & & -0.08 & & .0442 & & .6971 \\
\hline $\mathrm{La}$ & & & & & 51 & & .0378 \\
\hline & .39 & & -.05 & & 13 & & .0003 \\
\hline ALf & & & -1.24 & 0 & 73 & & .0482 \\
\hline $\mathrm{Lb}$ &.-( & $.0 S$ & -0.51 & 0 & 042 & & .1428 \\
\hline $\mathrm{Lm}$ & & & 0.47 & & .0225 & & .1591 \\
\hline Lru & & & -2.06 & 0.040 & .0168 & -.2447 & -.0190 \\
\hline Lfa & & .0701 & -0.04 & & .1870 & -.1405 & .1342 \\
\hline Lfs & & .00 & 0.32 & 0.749 & .9493 & -.0102 & .0143 \\
\hline Lf: & .0626 & .05 & 10 & 0.2 & .0293 & & . 1747 \\
\hline Lf & & .04 & -0.55 & & .0483 & -.1007 & .0566 \\
\hline Lfa & -.0 & .18 & -0.45 & & .0019 & -.4484 & .2802 \\
\hline & & .06 & -165 & 0.0 & .0117 & -.2467 & .0095. \\
\hline & -.01 & . 1006 & -0.11 & 0.91 & .0043 & -.2085 & . 1861 \\
\hline ALsc & -.2163 & .0643 & -2.56 & 0.01 & .0091 & -.3424 & -.0902 \\
\hline & .2156 & .2154 & 0.99 & 0.321 & .0021 & -.2066 & .6378 \\
\hline ALcart* & -.0231 & .0607 & -0.38 & 0.706 & .0233 & -.1422 & .0958 \\
\hline ALagri* & .1188 & .1468 & 0.83 & 0.409 & .0146 & -.1688 & .4066 \\
\hline ALserv* & .0453 & .1297 & 0.35 & 0.723 & .0126 & -.2089 & .2996 \\
\hline ALin & .0634 & .1348 & 0.48 & 0.632 & .0094 & -.2007 & .3277 \\
\hline ALpublic* & -.0375 & .1552 & -0.24 & 0.813 & .0031 & -.3418 & .2667 \\
\hline
\end{tabular}

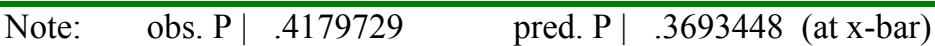

$\left(^{*}\right) \mathrm{dF} / \mathrm{dx}$ is for discrete change of dummy variable from 0 to 1 $\mathrm{Z}$ and $\mathrm{P}>|\mathrm{z}|$ are the test of the underlying coefficient being 0 
Table D10: Differences in Sergipe versus rest of NE

\begin{tabular}{|c|c|c|c|c|c|c|c|}
\hline \multicolumn{5}{|c|}{$\begin{array}{l}\text { Probit estimates } \\
\text { Log likelihood }=-4610.78\end{array}$} & \multicolumn{3}{|c|}{$\begin{array}{l}\text { Number of obs }=10236 \\
\text { LR chi2 }(40)=4701.41 \\
\text { Prob }>\text { chi2 }=0.0000 \\
\text { Pseudo R2 }=0.3377\end{array}$} \\
\hline $\mathrm{P} 0$ & $\mathrm{dF} / \mathrm{dx}$ & Std.Err. & $\mathrm{Z}$ & $\mathrm{P}>|\mathrm{z}|$ & & $95 \%$ & C.I.] \\
\hline$\overline{\text { age }}$ & -.0278 & $\mid .0032$ & -8.47 & 0.000 & 36.64 & -.0343 & -.0214 \\
\hline age_2 & .0002 & .0000 & 6.53 & 0.000 & 1468.94 & .0001 & .0003 \\
\hline fema* & .2126 & .0165 & 12.88 & 0.000 & .2181 & .1802 & .2450 \\
\hline black* & .0482 & .0248 & 1.97 & 0.049 & .0755 & -.0004 & .0969 \\
\hline mula* & .0758 & .0132 & 5.64 & 0.000 & .6432 & .0498 & .1019 \\
\hline rural* & .0525 & .0173 & 3.07 & 0.002 & .2145 & .0186 & .0865 \\
\hline fam. & .1839 & .014 & 12.86 & 0.000 & 3.6971 & .1561 & .2118 \\
\hline fsize_2 & -.0152 & .0013 & -11.29 & 0.000 & 16.57 & -.0179 & -.0126 \\
\hline fa 5 & .1813 & .0113 & | 16.14 & 0.000 & .4858 & .1591 & .2035 \\
\hline fa5_15 & .1336 & .0085 & 15.62 & 0.000 & .9068 & .1168 & .1505 \\
\hline fa_65 & -.2269 & .0338 & -6.69 & 0.000 & .0381 & -.2934 & -.1605 \\
\hline schol2* & -.0885 & .0158 & -5.45 & 0.000 & .2717 & -.1196 & -.0574 \\
\hline schol3* & -.1700 & .0165 & -9.39 & 0.000 & .1703 & -.2025 & -.1376 \\
\hline schol4* & -.3401 & .0139 & -20.03 & 0.000 & -.2635 & -.3675 & -.3127 \\
\hline schol5* & -.4229 & .0067 & -14.15 & 0.000 & -.0610 & -.4362 & -.4096 \\
\hline cart* & -.2013 & .0121 & -16.28 & 0.000 & .51358 & -.2250 & -.1775 \\
\hline agri* & .1724 & .0305 & 5.70 & 0.000 & .1701 & .1124 & .2323 \\
\hline serv* & -.0051 & 0233 & -0.22 & 0.825 & 4199 & -.0509 & .0406 \\
\hline ind* & .0226 & .0252 & 0.90 & 0.367 & .2745 & -.0267 & .0720 \\
\hline public* & -.0448 & .0377 & -1.16 & 0.245 & .0354 & -.1188 & .0290 \\
\hline SER* & .2241 & .3493 & 0.64 & 0.525 & .0481 & -.4604 & .9087 \\
\hline SERage & -.0079 & .0163 & -0.49 & 0.626 & 1.7219 & -.0399 & .0240 \\
\hline SERage_2 & .0001 & .0002 & 0.60 & 0.546 & 67.4916 & -.0002 & .0005 \\
\hline SERfema* & .0221 & .0774 & 0.29 & 0.773 & .0097 & -.1296 & .1739 \\
\hline SERblack* & -.0381 & .1327 & -0.28 & 0.778 & .0024 & -.2983 & .2220 \\
\hline SERmula* & -.0437 & .0676 & -0.63 & 0.527 & .0375 & -.1763 & .0888 \\
\hline SERrural* & -.047 & .0779 & -0.59 & 0.553 & .0143 & -.2002 & .1052 \\
\hline SERfam & -.0645 & .0680 & 0.95 & 0.343 & .1816 & -.1979 & .0688 \\
\hline SERfsi 2 & .0094 & .0075 & 1.26 & 0.209 & .8389 & -.0053 & .0242 \\
\hline SERfa_5 & .0069 & .0511 & 0.14 & 0.892 & .0260 & -.09336 & .1073 \\
\hline SERfa $\sim 15$ & -.0135 & .0402 & -0.34 & 0.736 & .0472 & -.0924 & .0652 \\
\hline SERfa_65 & -.3071 & .1941 & -1.58 & 0.114 & .0013 & -.6876 & .0733 \\
\hline SERsch $\sim 2 *$ & .0690 & .0792 & 0.89 & 0.375 & .0155 & -.0862 & .2244 \\
\hline SERsch 3* & .0651 & .0941 & 0.70 & 0.481 & .008 & -.1192 & .2496 \\
\hline SERsch 4* & -.0374 & .0930 & -0.39 & 0.693 & .0108 & -.2198 & .1449 \\
\hline SERcart* & . 1069 & .0653 & 1.67 & 0.095 & .0234 & 1.0210 & .2349 \\
\hline SERagri* & .0164 & .1353 & 0.12 & 0.903 & .0131 & -.2487 & .2816 \\
\hline SERserv* & -.0006 & .0998 & -0.01 & 0.995 & .0169 & -.1962 & .1950 \\
\hline SERind* & -.1059 & .0934 & -1.05 & 0.293 & .0118 & -.2891 & .0772 \\
\hline SERpub $\sim c^{*}$ & -.0209 & .1589 & -0.13 & 0.896 & .0017 & -.3324 & .2905 \\
\hline
\end{tabular}

Note: obs. P .4194021 pred. P | .373369 (at x-bar)

$\left.{ }^{*}\right) \mathrm{dF} / \mathrm{dx}$ is for discrete change of dummy variable from 0 to 1 $\mathrm{z}$ and $\mathrm{P}>|\mathrm{z}|$ are the test of the underlying coefficient being 0 
Table D11: Differences in Bahia versus rest of NE

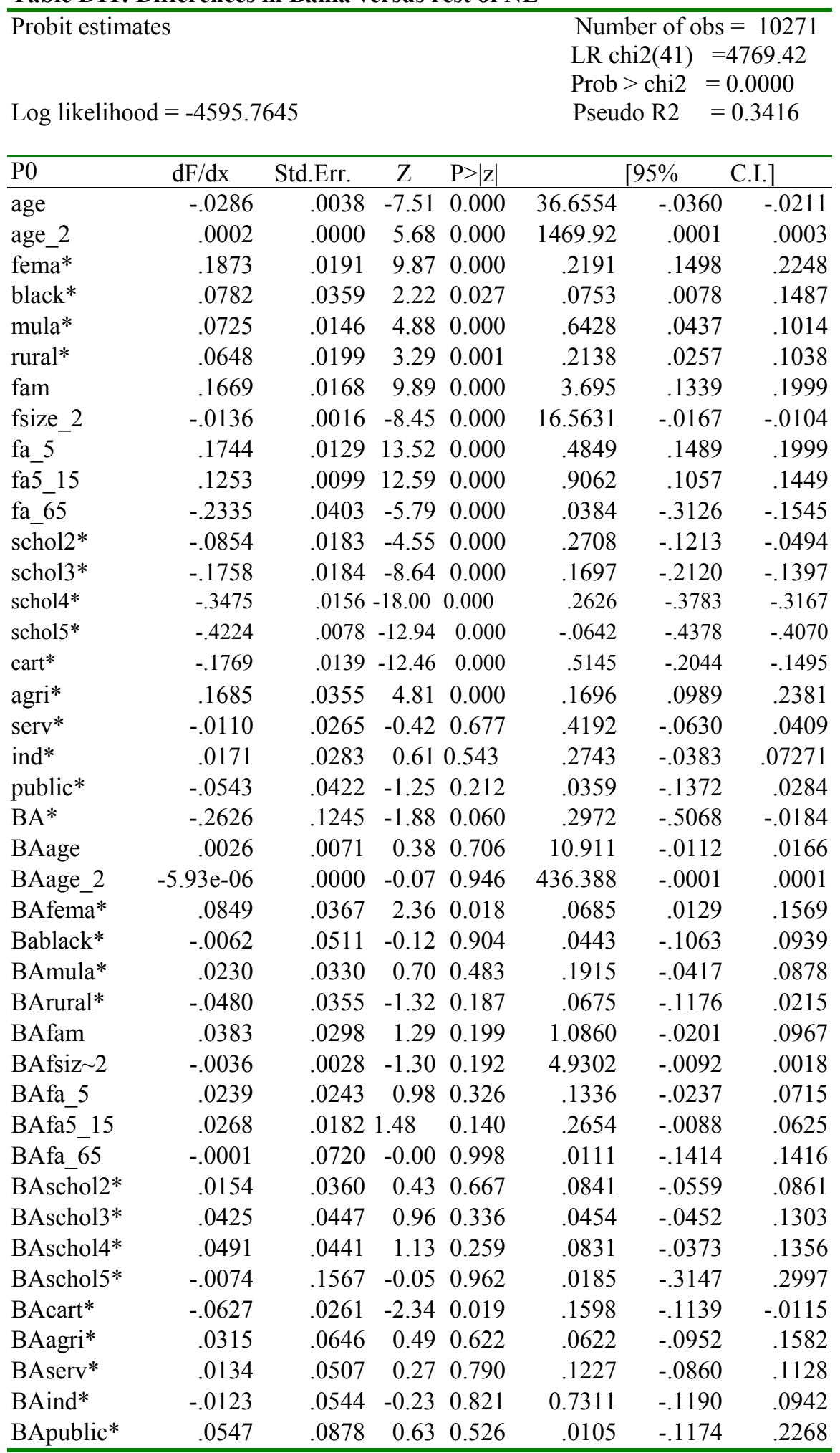

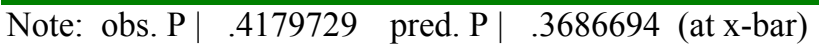

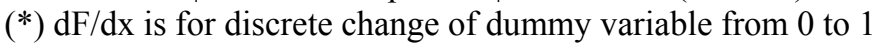
$\mathrm{Z}$ and $\mathrm{P}>|\mathrm{z}|$ are the test of the underlying coefficient being 0 


\section{Table D12}

Poverty Probit for Brazil (1999):

Probit estimates Number of obs $=38231$

LR $\operatorname{chi} 2(20)=13673.56$

Prob $>$ chi $2=0.0000$

Log likelihood $=-12830.156$ Pseudo $\mathrm{R} 2=0.3476$

$$
\text { Coef. } \quad \text { Std.Err. } \mathrm{P}>\mathrm{z} \quad[95 \% \text { Conf.Interval }]
$$

\begin{tabular}{lrlrrr}
\hline age & -0.0657 & 0.0052 & 0.00 & -0.0759 & -0.0556 \\
age $^{2}$ & 0.0006 & 0.0001 & 0.00 & 0.0005 & 0.0007 \\
feme & 0.4586 & 0.0248 & 0.00 & 0.4100 & 0.5073 \\
black & 0.3093 & 0.0348 & 0.00 & 0.2411 & 0.3774 \\
mulato & 0.4717 & 0.0189 & 0.00 & 0.4348 & 0.5087 \\
rural & 0.2563 & 0.0257 & 0.00 & 0.2059 & 0.3067 \\
fsize & 0.3326 & 0.0232 & 0.00 & 0.2872 & 0.3780 \\
fsize & -0.0280 & 0.0022 & 0.00 & -0.0323 & -0.0237 \\
fa5 & 0.5379 & 0.0167 & 0.00 & 0.5052 & 0.5706 \\
fa5_15 & 0.3814 & 0.0133 & 0.00 & 0.3554 & 0.4073 \\
fa65 & -0.4939 & 0.0569 & 0.00 & -0.6053 & -0.3825 \\
schol2 & -0.3763 & 0.0259 & 0.00 & -0.4270 & -0.3256 \\
schol3 & -0.6193 & 0.0305 & 0.00 & -0.6791 & -0.5595 \\
schol4 & -1.0188 & 0.0314 & 0.00 & -1.0803 & -0.9573 \\
schol5 & -1.9956 & 0.1002 & 0.00 & -2.1920 & -1.7991 \\
cart & -0.5905 & 0.0187 & 0.00 & -0.6272 & -0.5538 \\
agri & 0.2658 & 0.0454 & 0.00 & 0.1767 & 0.3548 \\
serv & -0.0824 & 0.0384 & 0.03 & -0.1577 & -0.0072 \\
ind & -0.0865 & 0.0408 & 0.03 & -0.1665 & -0.0064 \\
public & -0.1050 & 0.0652 & 0.11 & -0.2328 & 0.0228 \\
Const. & -0.2351 & 0.1112 & 0.04 & -0.4532 & -0.0171 \\
\hline & & & & &
\end{tabular}


Table D13

Poverty Probit for Northeast (1999):

Probit estimates Number of obs $=10166$

LR chi2(20) $=4671.26$

Prob $>$ chi $2=0.0000$

Log likelihood $=-4579.6642$ Pseudo R2 $=0.3377$

\begin{tabular}{lrllrr}
\hline \multicolumn{7}{c}{ Coef. } & Std.Err. P $>$ z & {$[95 \%$ Conf.Interval $]$} \\
& & & & & \\
\hline age & -0.0746 & 0.0086 & 0.00 & -0.0914 & -0.0578 \\
age $^{2}$ & 0.0007 & 0.0001 & 0.00 & 0.0005 & 0.0009 \\
feme & 0.5559 & 0.0418 & 0.00 & 0.4741 & 0.6377 \\
black & 0.1392 & 0.0633 & 0.03 & 0.0152 & 0.2632 \\
mulato & 0.2070 & 0.0353 & 0.00 & 0.1378 & 0.2763 \\
rural & 0.1217 & 0.0439 & 0.01 & 0.0357 & 0.2078 \\
fsize & 0.4817 & 0.0368 & 0.00 & 0.4095 & 0.5539 \\
fsize & -0.0399 & 0.0035 & 0.00 & -0.0468 & -0.0331 \\
fa5 & 0.4836 & 0.0290 & 0.00 & 0.4268 & 0.5405 \\
fa5_15 & 0.3508 & 0.0221 & 0.00 & 0.3075 & 0.3942 \\
fa65 & -0.6421 & 0.0886 & 0.00 & -0.8157 & -0.4685 \\
schol2 & -0.2362 & 0.0429 & 0.00 & -0.3203 & -0.1520 \\
schol3 & -0.4791 & 0.0504 & 0.00 & -0.5778 & -0.3804 \\
schol4 & -1.0394 & 0.0506 & 0.00 & -1.1385 & -0.9403 \\
schol5 & -2.3779 & 0.1640 & 0.00 & -2.6993 & -2.0564 \\
cart & -0.5201 & 0.0323 & 0.00 & -0.5835 & -0.4568 \\
agri & 0.4276 & 0.0758 & 0.00 & 0.2790 & 0.5761 \\
serv & -0.0275 & 0.0600 & 0.65 & -0.1452 & 0.0901 \\
ind & 0.0329 & 0.0643 & 0.61 & -0.0931 & 0.1590 \\
public & -0.1191 & 0.1013 & 0.24 & -0.3176 & 0.0794 \\
Const. & 0.1967 & 0.1815 & 0.28 & -0.1590 & 0.5524 \\
\hline & & & & & \\
\hline & & & &
\end{tabular}


Table D14

Poverty Probit for Rio Grande do Norte (1999):

Probit estimates Number of obs $=505$

LR $\operatorname{chi} 2(19)=212.66$

Prob $>$ chi $2=0.0000$

Log likelihood $=-243.42262$ Pseudo R2 $=0.3040$

Coef. Std.Err. $\mathrm{P}>\mathrm{Z} \quad$ [95\%Conf.Interval]

\begin{tabular}{|c|c|c|c|c|c|}
\hline age & -0.0625 & 0.0390 & 0.11 & -0.1389 & 0.0140 \\
\hline $\operatorname{age}^{2}$ & 0.0007 & 0.0005 & 0.15 & -0.0003 & 0.0016 \\
\hline fem & 0.4669 & 0.1982 & 0.02 & 0.0784 & 0.8554 \\
\hline black & -0.5008 & 0.6125 & 0.41 & -1.7014 & 0.6997 \\
\hline mula & -0.0240 & 0.1459 & 0.87 & -0.3100 & 0.2619 \\
\hline rural & 0.3013 & 0.1468 & 0.04 & 0.0135 & 0.5891 \\
\hline fsize & 0.3941 & 0.1843 & 0.03 & 0.0329 & 0.7553 \\
\hline fsize $^{2}$ & -0.0456 & 0.0172 & 0.01 & -0.0794 & -0.0118 \\
\hline fa5 & 0.7019 & 0.1317 & 0.00 & 0.4439 & 0.9600 \\
\hline fa5_15 & 0.4701 & 0.1057 & 0.00 & 0.2629 & 0.6772 \\
\hline fa65 & -1.0891 & 0.7296 & 0.14 & -2.5190 & 0.3408 \\
\hline schol2 & -0.4494 & 0.1809 & 0.01 & -0.8040 & -0.0948 \\
\hline schol3 & -0.5815 & 0.2250 & 0.01 & -1.0225 & -0.1405 \\
\hline schol4 & -1.1143 & 0.2211 & 0.00 & -1.5476 & -0.6809 \\
\hline cart & -0.4525 & 0.1457 & 0.00 & -0.7381 & -0.1669 \\
\hline agri & 0.1394 & 0.3169 & 0.66 & -0.4817 & 0.7604 \\
\hline serv & -0.2672 & 0.2751 & 0.33 & -0.8064 & 0.2720 \\
\hline ind & -0.1032 & 0.2817 & 0.71 & -0.6553 & 0.4489 \\
\hline public & -0.5754 & 0.4110 & 0.16 & -1.3810 & 0.2302 \\
\hline Const. & 0.4117 & 0.8559 & 0.63 & -1.2658 & 2.0892 \\
\hline
\end{tabular}

